


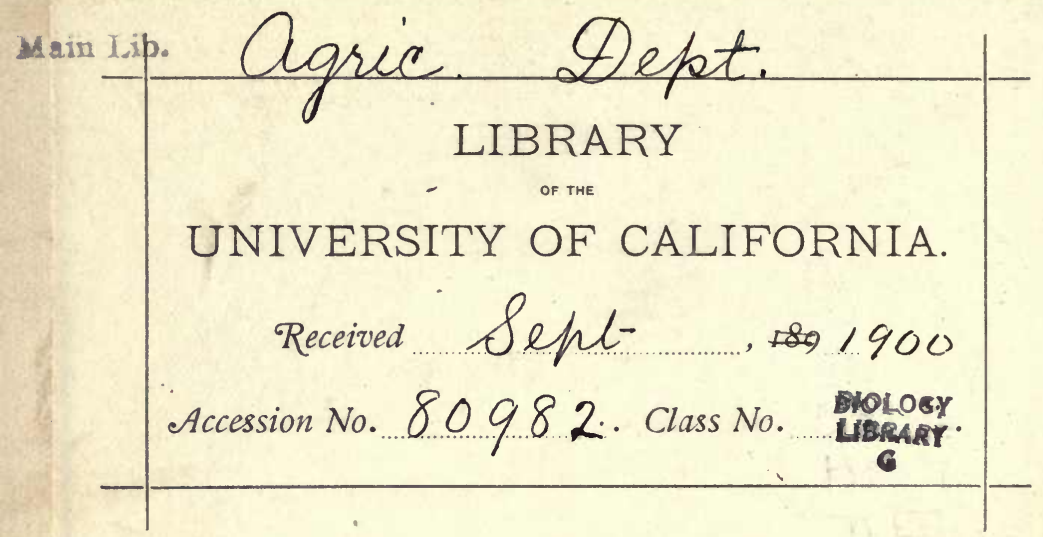






\section{THE PRINCIPLES OF BACTERIOLOGY}





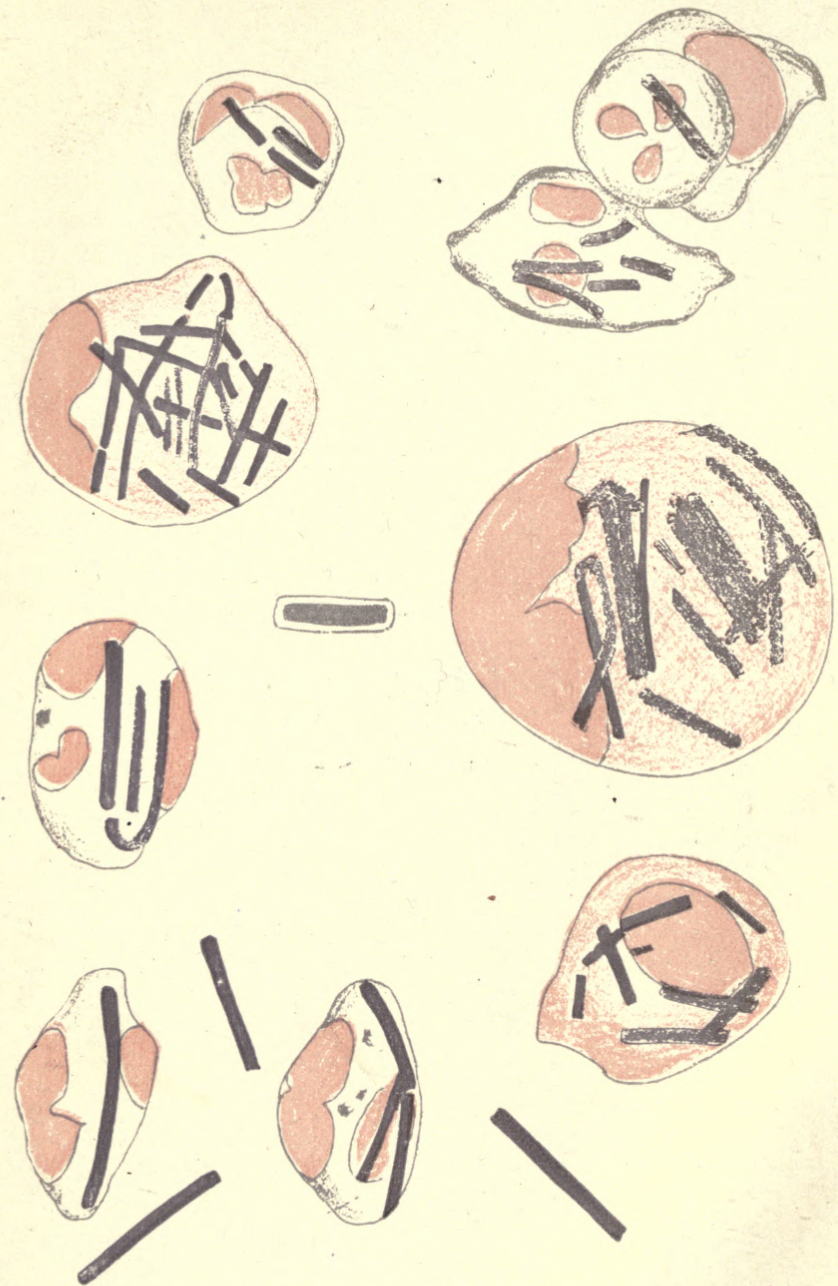

Phagocytosis (After Metschnikoff). 


\section{THE PRINCIPLES}

\section{OF \\ BACTERIOLOGY}

BY

DR. FERDINAND HUEPPE

PROFESSOR OF HYGIENE IN THE UNIVERSITY OF PRAGUE

AUTHORIZED TRANSLATION FROM THE GERMAN

BY

DR. E. O. JORDAN

ASSISTANT PROFESSOR OF BACTERIOLOGY IN THE UNIVERSITY OF CHICAGO

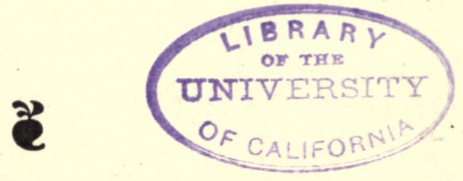

\section{CHICAGO}

THE OPEN COURT PUBLISHING COMPANY

London: Kegan Paul, Trench, Trübner \& Co.

I 899 


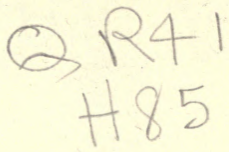

BIOLOBY

LIBRARY

G

\author{
Main Lib. \\ isric. Dept. \\ 80982 \\ COPYRIGHT, I899 \\ By THE OPEN COURT PUBLISHING COMPANY \\ CHICAGO \\ All rights reserved
}




\section{TRANSLATOR'S NOTE}

In the translation of Prof. Hueppe's book I have endeavored simply to reproduce the author's ideas with clearness and fidelity. I have added some footnotes and a few references to important and classic papers and to lately published work of interest, without, however, any pretension to completeness. In the main the book is presented as it came from the hands of the author.

EDWIN O. FORDAN. 



\section{PREFACE.}

BACTERIOLOGY is just now in transition from the natural history stage to the scientific. The former aspect is adequately treated in some good and comprehensive manuals which attempt to bring together all the available data, and there exist also some good short text-books which contain, in addition to an exposition of methods, the more important facts of the subject set forth with especial view to the needs of the physician. The way in which bacteriology originated and especially the mode of development of methods of investigation have brought it to pass that the natural history side has been kept in the foreground while the scientific side has been relegated almost exclusively to the sections dealing with protective inoculations.

This mode of treatment, however, no longer suffices to meet a growing and legitimate demand. In this book I wish to present an attempt at a critical and comprehensive exposition of bacteriology basing it clearly and solidly upon scientific conceptions. I make this 
essay in order that our knowledge of the causes of putrefaction, fermentation and disease, together with the methods of the prevention and cure of infection, may develop in a way free from all ontology. It is sometimes of use to restate things which are axiomatic. The " entities" or "essences," which even in the age which has discovered the law of the conservation of energy and the evolution of living things by means of the struggle for existence, still hannt the mind of the physician who remains sunk in the ontological contemplation of diseased cells and disease-producing bacteria, are a mere remnant of priest medicine and can have 110 place in any saientific conception of biology, pathology or hygiene.

Without trenching in any way upon the field of works which aim at bringing together all the material at our disposal or at the special introduction of physicians to the subject, I may be permitted to hope that this first mechanical and monistic exposition of bacteriology will be welcomed by many readers as a complemant of the other works, and that it will commend itself as a trustworthy guide to all who wish to make themselves acquainted with the present standpoint and the prospective progress of scientific bacteriology. For this reason I have given adequate recognition not only 
to the point of view of the physician, but to that of the botanist, the general biologist, and the chemist, and indeed to that of all those who have a general interest in the progress of modern science and who wish to inform themselves upon the practically important questions of the day.

Like all branches of theoretical and practical medicine, bacteriology owes much of its early advancement to the leaders of the Prussian army medical department. The Prussian surgeon Struck, as head of the Imperial Board of Health in Berlin, took the initiative in creating the first standard working laboratory, which served as a model for all subsequent institutes ; without this powerful aid Koch could not have developed his pioneer methods.

Earlier pupils of the army medical school, like Helmholtz, Virchow, Reichert, Leyden, Fischer, and Nothnagel had already achieved important professional positions; and upon the establishment of hygienic and bacteriological laboratories and the creation of professorships, German army physicians, and chiefly indeed those who were pupils of this institute, appeared as workers of the first rank; among these I may name, Behring, Buchner, Fischer, Gärtner, Gaffky, Löffler, R. Pfeiffer and Schröter. I myself also have the honor to be a pupil of this 
institution. It is an especial pleasure to me, therefore, in grateful remembrance of the help that I received from Surgeons-General Grimm and v. Coler, the present honored head of the Prussian Army Medical School, and from my former chief, Army Surgeon Struck, to dedicate this work to the famous institution, on this its centennial anniversary.

\section{The Author.}

Prague, August 2, I895. 


\section{TABLE OF CONTENTS.}

CHAPTER

PAGE

I. The Structure of Bacteria............... I

II. The Vital Phenomfina of Bacteria........... 50

Anaërobiosis ; Relations to Energy.............. 50

Light and Temperature; Sterilization............ 6I

Disinfection; Effect of Poisons................. 7 I

Chemistry of the Nutrient Substratum........... 9I

Active Proteids ; Ptomaïns ; Leucomaïns.... ........ I 18

Effect of Bacteria Upon the Substratum .......... I 25

Practical Applications.................... I 32

Cycles of Activity and Adaptation.............. I 38

III. Brief Descriptions of the Most Important Pa-

THOGENIC BACTERIA................ I46

IV. The Cause of Infectious Disease............. 220

Causes and Their Identity and Equivalence With Effects. 230

Resistances and External Conditions... ....... .. 232

The Liberation of Energy................. 234

Atomic Combinations and Resistances........... 237

Predisposition to Disease : Acquired and Inherited.... 242

Disease-Stimuli ........................ 25

Infection and Contagion. .................. 272

V. Can Disease Be Cured by Combating the Cause? 275

VI. Immunity; Protective-Inoculation ; Curativf. In-

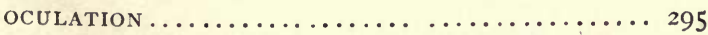

Isopathic or Specific Inoculation With Living Parasites;

Attenuation of Disease-Producing Bacteria....... 300

Inoculation With Metaljolic Products; Protective Substances and Poisons; Immunity Does Not Depend

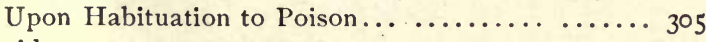

Proteids........................... 312 
Protective Serum; Active and Passive Immunity; Tissue

Immunity and Antitoxin Immunity ...................... $3^{16}$

The Nature of Antitoxin....................... 327

Do the Antitoxins Bring About Specific Immunity?... 332

Anticipatory Inoculations; Specific Curative Inocula-

tions; Specific Serum Therapy............. 34 I

Phagocytes and Alexins ; Antitoxic and Bactericidal Sub-

stances in the Blood..................... 357

Are There Protective and Curative Inoculations that Are

Non-Specific ?........................ 377

Protective and Curative Inoculations Without the Use of

Micro-Parasites or Their Products............ 390

ViI. The Prevention of Infectious Disease by Com-

bating the Cause of the Disease........... 398

- Vili. The History of Bacteriology ............... 440

Bibliography................................... 457 


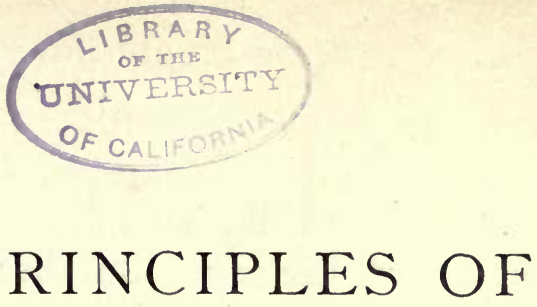

THE PRINCIPLES OF BACTERIOLOGY.

\section{CHAPTER I.}

THE STRUCTURE OF BACTERIA.

DURING the last decade the science of bacteriology has become one of the most prominent branches of the tree of knowledge. Words of the craft, like " pure culture," belong as much as the phrases "struggle for existence" and "conservation of energy" to those scientific idioms which have been admitted to citizenship in the general community of speech.

The organisms known as bacteria are members of the lowest group of the plant kingdom. They would in themselves arouse hardly more attention than some of the algæ, slime-fungi, or moulds, were it not for the supervention of some special interest. This special interest lies in the fact that bacteria are those organisms which research has brought into relation with the questions of spontaneous generation, fermentation and decay, and the origin of dis- 
ease. It was consideration of the most important questions of biology and pathology, of science and of medicine, that first directed attention towards bacteria. But these subjects have not of course been developed exhaustively by reference to bacteria alone. Small organisms belonging to other groups of the plant kingdom and even to the animal kingdom stand in a similar relation to the questions involved; and we may speak with greater precision of micro-biology, indicating by that term a vast territory into which investigation has made only an excursion. If we still continue to allot to bacteria the major part of this territory, we are justified for the reason that bacteria are the organisms whose participation in important biological phenomena was first discovered, and because, owing to the development of special methods of bacterial investigation, we at present possess in this group of microbes the most favorable material for research.

In this chapter we shall consider questions relating to bacterial structure. The points which are of the greatest general interest are those bearing upon the constancy and variability of form, and upon the cellular structure which is especially interesting because these organisms are ordinarily regarded as the lowest in the scale of life. 
In the simplest and smallest of living things, visible only with the aid of the microscope, the entire body consists of a single cell. The bodies of all the larger and higher forms of life are built up out of structural units similar to these independent cell-organisms. All cells are essentially minute masses of a substance called protoplasm, a semi-solid, gelatinous substance which, viewed with the ordinary microscope, is apparently homogeneous, but which, according to Altmann, consists of small granules of an albuminous nature, embedded in a similar, structureless albuminous matrix. These elementary granules or granula, are often arranged in threads, sometimes in such a way as to form a sponge-like network or reticulum; Bütschli, however, regards protoplasm as essentially a liquid, possessed of a foam-like or "honeycomb" structure. On Altmann's view, the "granule" is the vital unit, and a cell in its simplest form is to be regarded as a colony of such "elementary granules" rather than as a true physiological and morphological unit. But, as a matter of fact, the cell is the simplest and lowest form of living thing now known, a true " elementary organism " (Brücke) or "seat of life" (Virchow). Growth and reproduction, which we recognize as conspicuous phenomena of life, are always 
met with in the cell; while it must be admitted that at the present time we can only in a limited sense regard the granules composing the cell as endowed with the peculiar properties of life. If there exist cells composed solely of protoplasm (Monera, Haeckel), which contain, tliat is, only the "granules," or the threads, meshwork, or froth constructed out of these particles, such cells theoretically would be the least differentiated, and might be regarded as those from which the higher forms have been developed. It was supposed for a time that free cells of this kind, consisting wholly of pure protoplasm, existed in the form of Haeckel's "Urschleim," but the existence of such structures has not been confirmed.

Bodies which are undoubted cells all show some degree of differentiation. Indeed, animal cells always, and plant cells almost always, contain a definite rounded body called the nucleus. Only some of the lowest plant cells appear to be devoid of a nucleus. Many cells, especially plant cells, are surrounded by a dense wall or cell-membrane. Many cells also contain vacuoles; either true cavities or cavities filled with fluid; and frequently granules other than protoplasm are found associated with the cell-substance, the name paraplasm or deutoplasm being given to these particles. These mor- 
phological elements of the cells are in fact primitive organs. The nucleus seems to be specially concerned in the division and reproduction of the cell; the membrane serves partly as a means of protection, but also influences reproduction in so far as it limits the size of the cell and modifies nutrition; the paraplasm consists of food-material, reserve substances, secretions and the various metabolic products ; the vacuoles assist in the digestion and distribution of nutrient substances; while the protoplasm, in a more precise sense, attends to respiration and assimilation. The protoplasm possesses also the property of contractility, and, in consequence, has the power of changing its place or moving about.

Bacteria were regarded by Ehrenberg (1838) as very complicated "infusion-animals," while later they came to be looked upon as quite simple vegetal organisms consisting merely of protoplasm and a membrane. At present we halt midway between the conception of great simplicity in organization and that of great complexity. The bacterial cell consists of finely granular protoplasm, which in the smallest forms is apparently homogeneous, and which, according to Alfred Fischer, behaves toward reagents like plant protoplasm. In the cell-body there are sometimes to be seen 
so-called paraplastic granules of an oily or of a starchy character, grains of sulphur, and at times vacuoles. The cell-membrane has been long known and the fact of its existence securely established. It consists in some instances of a substance physically altered, but akin to protoplasm, and is of a proteid nature, thereby resembling the membrane of animal cells. Some species, however, possess a cellulose-like membrane resembling that of the typical plant cell.

Many years ago I was able to show that during the division of bacteria there occurred a very remarkable arrangement of the granules made visible by staining, which is similar to that taking place in the division of the nuclear filaments of higher cells. The manner in which the general bacterial substance stains is also suggestive of nuclear and not of cytoplasmic reaction. Bütschli ${ }^{\mathrm{x}}$ definitely conceives the whole central part of the cell to be the nucleus ; according to this conception, the smallest bacteria would possess hardly more than a mantle of cytoplasm and often would consist entirely of nuclear substance. More often it is possible to detect the presence of granules which react like nuclear substance, and which must, therefore,

${ }^{1}$ Cf. Weitere Ausführungen über den Bau der Cyanophyceen und Bakterien, Leipzig, 1896 . 
1.

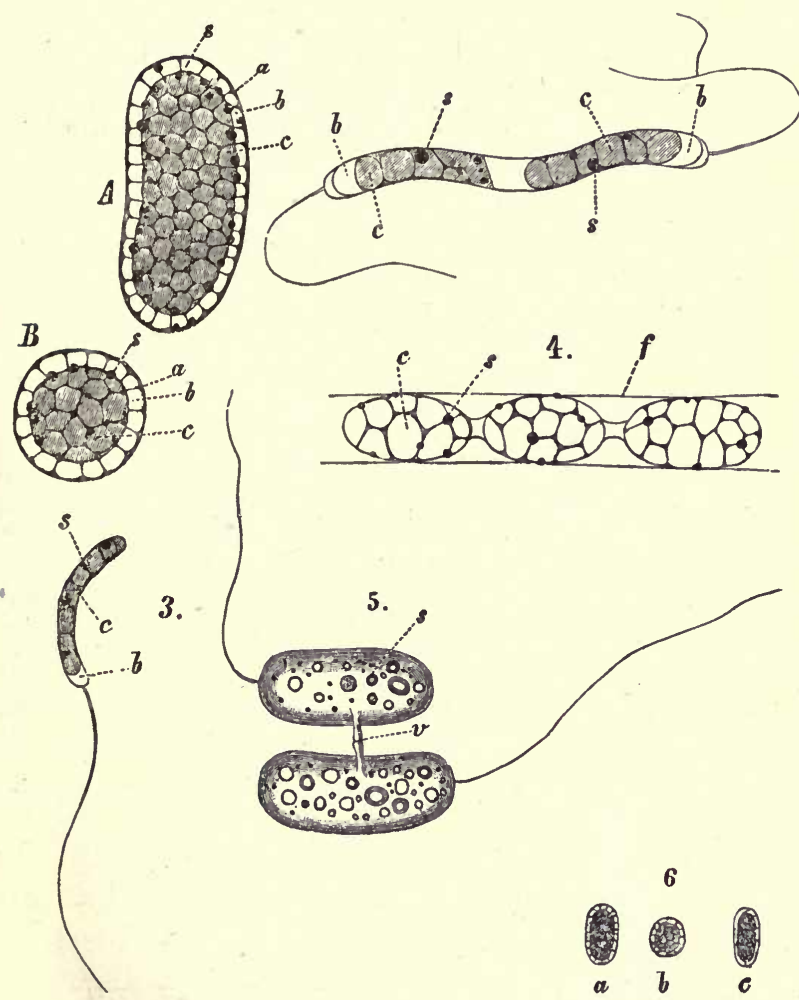

Fig. 1.-The Structure of Bacteria (after Butschli). I -5 correspond to about 2000-2500 linear magnification.

I. A, Chromatinm Okenii in optical longitudinal section; $B$, in optical cross-section. Killed with alcohol and stained with hæmatoxylin after the bacterio-purpurin and sulphur grains have, been dissolved out. The reticular appearance is regarded as the optical expression of a foam-like structure : the central body, $c$, is more compact than the peripheral layer $b$; the thickenings at $a$ accord with the view of a foam structure. While the reticulum itself stains with the blue color of alkaline hæmatoxylin, the granules, $a$, give the violet-red color of acid hæmatoxylin ; with methylene blue also the granules stain red, the reticulum blue. According to Butschli the central body, $c$, is the nucleus, the 
peripheral layer, $b$, the mantle of cytoplasm, the red granules, $e$, are chromatin grains and the blue reticulum is linin.

2. Spirillum undula in process of division. The nucleus, $c$, lies next to the membrane ; the cytoplasm, $b$, occupies a relatively small part of the cell and is found at the poles and in the middle.

3. A bacterium found in stagnant water; the cell is almost wholly nuclear substance, $c$, and the cytoplasm, $b$, is confined to a small amount at one pole.

4. Cladothrix dichotoma; portion of filament, $f=$ sheath.

5. Chromatium Okenii in conjugation (after F. Forster), $s=$ sulphur grains ; $v=$ the channel of connection between the conjugating cells.

6 . $a$ and $b$, Chromatium Okenii; $c$, B. lineola (after a photograph) ; linear magnification about 900.

be regarded as undeveloped nuclei. (Fig. I.) Ernst was the first to observe these granules which stained red and not blue with methylene blue. A. Fischer ${ }^{\mathrm{I}}$ has, however, recently maintained that this coloration was due not to a chemical peculiarity, but to physical conditions. In his opinion the substance of a bacterial cell, in spite of the fact that it stains after the manner of nuclear substance, behaves on the whole like the cytoplasm of a plant cell. When it is plasmolyzed by strong salt solution, alcohol or heat, it adheres to the cell wall and breaks up into irregular masses or even at times into masses so regular as to present the appearance of "central bodies" or polar granules (Fig. 2). The "central body" of Bütschli is therefore considered by Fischer as merely plasmolyzed cytoplasm. Whatever be the truth of the matter, the bacterial cell is certainly not the simplest form of cell that may

1 Ueber den Bau der Cyanophyceen und Bakterien, Jena, I897. 

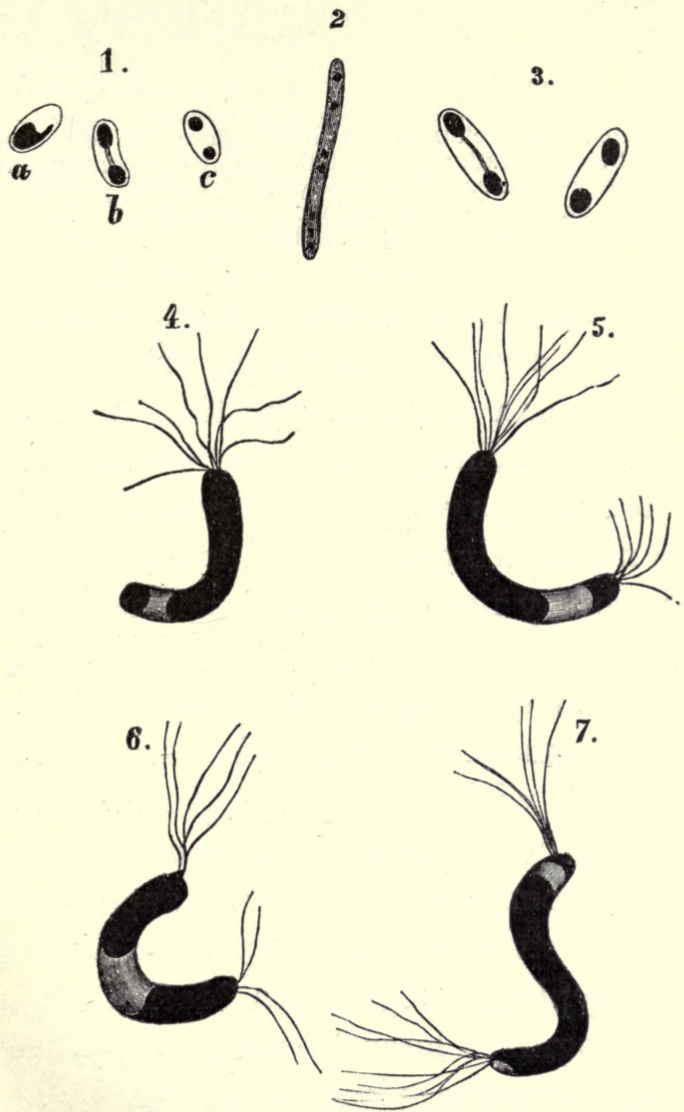

Fig. 2.-The Structure of Bacteria (after Alfred Fischer).

Appearances obtained by plasmolysis.

I-3 enlarged $\mathrm{I}: \mathrm{I} 500$.

I. The comma bacilli of Finkler and Prior, plasmolyzed with 5 p. c. $\mathrm{NaCl}$ solution, showing contraction of the cell contentsthe nucleus according to Butschli-into $a$ and $b$, and finally the breaking up into $c$, two polar granules.

2. Leptothrix buccalss after treatment with Io p. c. nitric acid; the membrane is more translucent than the contracted and disintegrated cell contents.

3. Clostridium butyricum treated with 5 p. c. $\mathrm{NaCl}$ solution. 
4-7. Spirillum undula treated by the method of drying, and staining with aniline dyes; in the different stages of division and in different individuals the cell contents (Buitschli's "central body" or "nucleus") contract in various ways : 6 alone shows a sort of division into two new central bodies that accords with Bütschli's interpretation. In all the figures the cell substance is dark, the cell wall, which is left free by the contraction of the contents, is clearer and is faintly stained in the process of stain.. ing the flagella; the outer layer, however, is not a mantle of cytoplasm as supposed by Bütschli.

be conceived to exist, and in this connection it is safe to claim only that it is the lowest cell form that can without question be regarded

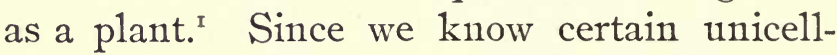
ular organisms whose relations to the plant and animal kingdoms are doubtful, bacteria are probably not the most rudimentary form of cell.

In the early studies of bacterial forms certain kinds with marked characteristics were found in connection with various specific diseases and specific decompositions. These could be distinguished from one another with such ease that particular stress was laid upon the description of such typical, "regulation" forms. It came to, be recognized later, however, that these different cell-forms are linked together by all possible intermediate stages. In order to permit of a rapid orientation it has, therefore, become the general practice to enumerate only three chief form groups:

1 Perty and F. Cohn were the first to recognize the affinity of these organisms to the plant kingdom. 
a. Coccus-forms, comprising spherical and ellipsoid cells.

b. Rod-shaped forms, plainly elongated in one direction. These may be distinguished according to their length as long or short rods. Many rods have an approximately uniform diameter throughout and the ends may be either rectangular in outline or more or less rounded. In some rods the diameter of the cell varies in different portions so as to produce a spindle-shaped or club-shaped cell, or one fashioned like a pestle, or a whetstone or a drumstick. Rods may be rigid or flexible, and, in the latter case, often appear curved.

c. Corkscrew forms, comprising all spirally twisted cells. The smallest forms often resemble rods bent with a comma-like flexure. The screws may be rigid or flexible, of equal diameter throughout, or varying in diameter at different points.

Each bacterial cell is able to maintain an independent existence, and frequently exhibits transition forms in the course of its own development. A sphere elongates into an ellipsoid; a long rod stretches out, divides and becomes two short rods; a short rod or spiral divides into two ellipsoids or spheres. Before division, the individual cells as a rule elongate, and their forms become thereby more clearly 
defined. Conversely, the young daughter cells are smaller and consequently less distinct (Fig. 3). The value, then, of the individual shapes fluctuates very greatly. At times it is the transitory division form, at times the com-

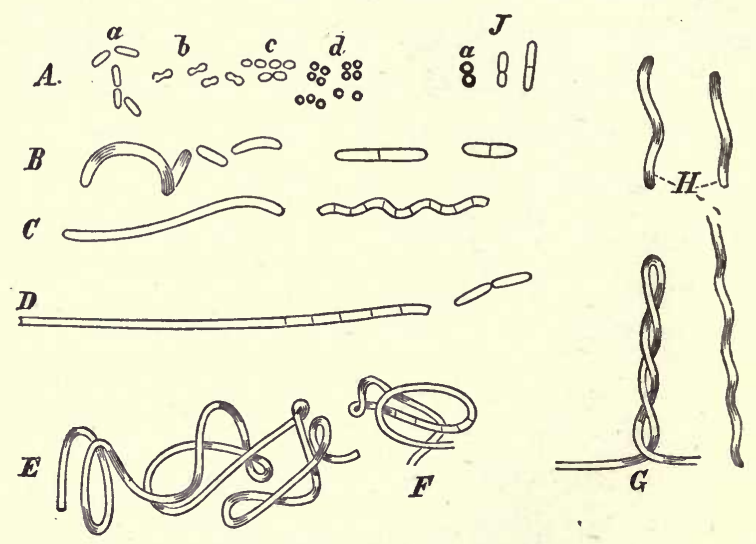

Fig 3.-Bacterium Zoffii (after Kurth). A, Short rods in process of division into arthrospores, $d$. $B$, Longer rods. $C$, Curved threads or filaments, in part segmented. $D$, Straight filaments in part segmented. $E$ and $F$, Twisted filaments and coils. $G$ and $H$, Spiral forms. $J$, Germination of the arthrospores.

mon mature form that is deemed "typical." Only as applied to the mature forms does the above grouping hold good. On this account it is superfluous, at least in the beginning, to determine with rule and compass the "regulation " length or breadth of a species, while general morphological questions remain unsettled which are plainly of more consequence.

It must be remarked furthermore that even 
the typical forms recur only under quite definite conditions and that they vary according to the nutrient media in which the bacteria are growing. This holds true, indeed, to such an extent that the prevailing form of a given species must be assigned to one group or another, according as it has been taken from one or another medium. In this way bacteria have been shifted from one class to another, as for example is the case with the "miracle germ" which, in accord with its common form, was originally placed among the spherical bacteria, but has been removed under the bacteriological régime to the group of rod bacteria; in truth, it may be rightly placed in either group.

After division the single cells may remain in more or less intimate union (Fig. 4). The individual members of this association may either preserve an independent existence, so that the association is simply a loose aggregation of cells, or the union may be so close that the group of cells appears to form an organic unit.

$A$. If division takes place in a single plane, chains and filaments of cells arise ; the members of the chain may be sharply defined one from another or may be without apparent boundary. In the latter case long filaments are formed which, from their possession of an outer 


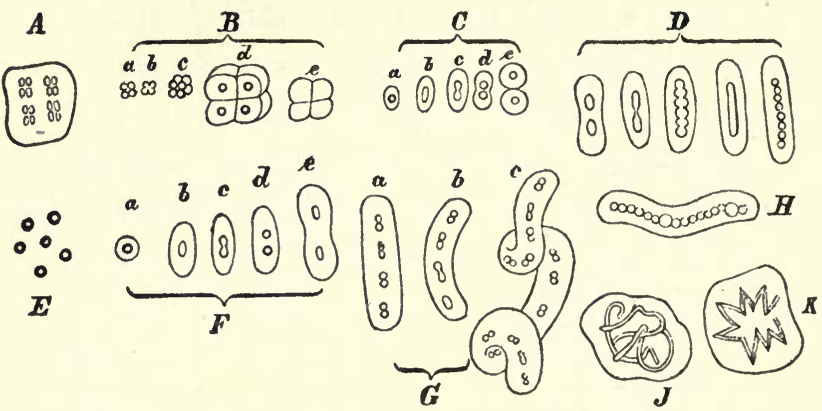

Fig. 4-Groupings of bacteria found in the larger zoögloæe. $A$ Single layered tetrads. $B$, Development of the tetrads, $a, b, c$ into the packets, $d, e$, the cubical arrangements of cells being shown in $d$, but not in $e$. C, Coccus-forms with capsules. $D$, Development of rods and subsequent breaking up of these into cocci inside of a capsule (Friedländer's Pneumobacillus). E-H, Leuconostoc. $E$, Arthrospores and $F$, their germination, and $H$, their reformation. $J$ and $\boldsymbol{K}$, Spiral forms in gelatinous envelopes or capsules, formerly described as the genus $M y$ conostoc.

sheath and by their true branching, betray an affinity to the fission-algæ (Fig. 5). Both threads and filaments may according to the rigidity of the membrane be motile or nonmotile, straight or wavy in outline, or spirally twisted. The spiral threads are closely or loosely wound, stiff or yielding. At times a single filament may be found straight, curved and spirally twisted, at different points. It sometimes happens that motile filaments form loops, or roll up into coils, or wind around one another like whiplashes. Certain kinds show a distinction between base and apex.

It is often difficult at first sight to determine 


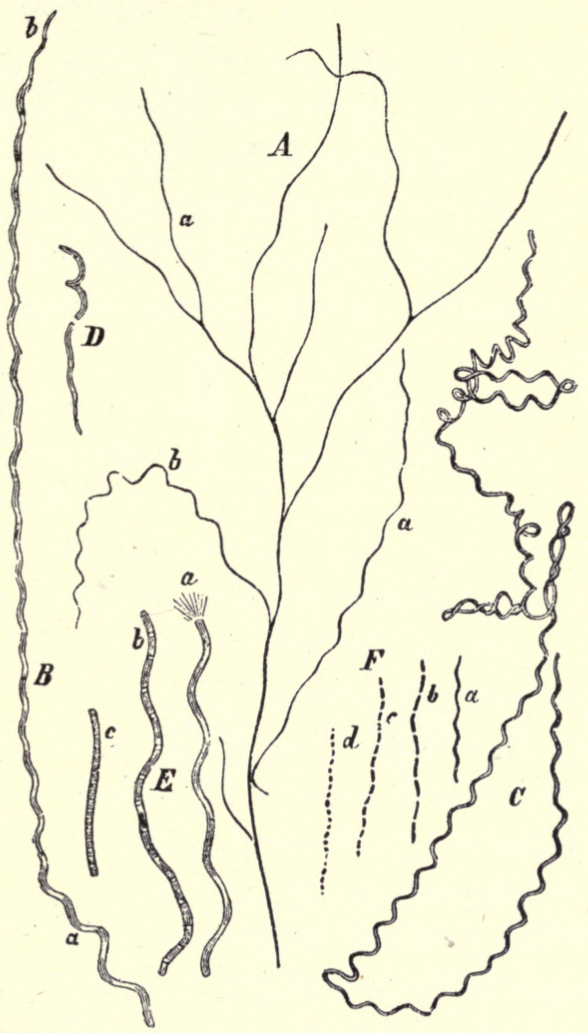

Fig. 5.-Cladothrix dichotoma (after Zopf) $A$, Branched filament with spiral branches more $(b)$ or less $(a)$ twisted. $B$, Screw forms one end of which $(a)$ is more twisted than the other. $C$, Long spirochæte-like branch with numerous coils and twists. $D$, a piece of a branch with sharp angled spirals, and one with very slight turns. $E$, Screw forms : $a$, unsegmented, $b$, with the appearance of segmentation into longer and $c$, into shorter segments. $F$, Spirochæte forms : $a$, unsegmented, $b-d$, schematic representation of segmentation, $b$, into long, $c$, into short rods and $d$, into cocci.

whether the form under observation is merely a chain of single rod-like or spiral cells, or is a 
real filamentous species, and whether the individual elements in the association are large or small. Early observers indeed, especially Ehrenberg and Naegeli, fell into the error of assuming that there is really only one fundamental form, the coccus, out of which by various combinations all the other forms call be derived.

$B$. Growth can occur also in two dimensions so that flat sheets of cells are formed. If growth takes place by cross-division, then groups of four cells, tetrads or tablet-forms, result. If division is longitudinal in rods which remain in contact at one point, a radiating structure is produced (Fig. 6).

C. By division of the cells in all three dimensions, cubical masses or packets like bales of merchandise are formed. These are the socalled Sarcine (Fig. 7).

$D$. Finally there may arise wholly irregular groups or heaps which have a spherical, lobed or botryoidal appearance. To such irregular cell-clusters names like Ascococcus, Staphylococcus, Clathrocystis, Zoögloea ramigera, etc., have been applied (Fig. 8). Individual cells may be grouped and united in different ways in one and the same species under varying conditions of life.

Among the rod-shaped organisms especially 


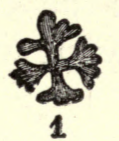

1.
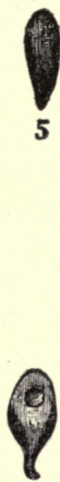

9
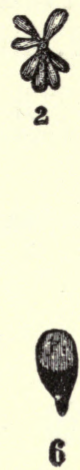

6

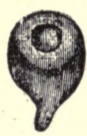

10

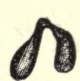

3

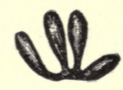

4

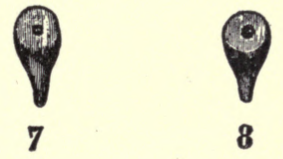

Fig. 6.-Pasteuria ramosa (after Metschnikoff).

I-4. Stages of the longitudinal division showing the resulting ray-like arrangement of cells.

5-I2. Formation of endospores (after drawings). Magnified about $\mathrm{I}: 2000$.

it has been observed that during the course of development straight rods sometimes undergo a thickening in the middle of the cell, thus becoming spindle-shaped, or at the end, causing a club-shaped appearance. In some cases these enlarged bacilli seem to be forms especially concerned in the production of fermenta- 
tion, as Hansen ${ }^{\mathrm{I}}$ has observed to be the case with the acetic acid bacteria, and Hueppe with

A.

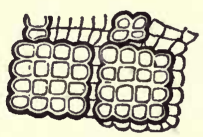

B.
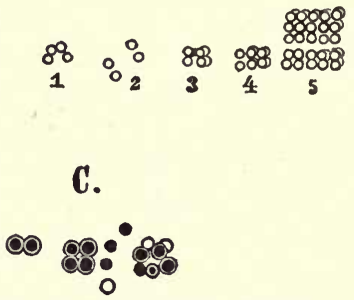

Fig. 7.- $A$. Sarcince from the stomach (after DeBary), fresh, unstained. Drawings magnified I : 600 .

B. Sarcina minuta (De Bary). I, cocci, 2, division into diplococci, 3 , single-layered tetrads or merista forms, 4 and 5 , formation of packets.

C. Sarcince from the lung, double-stained preparation showing endospores; the dark portions are the (red) spores either in the (blue) cells or isolated.
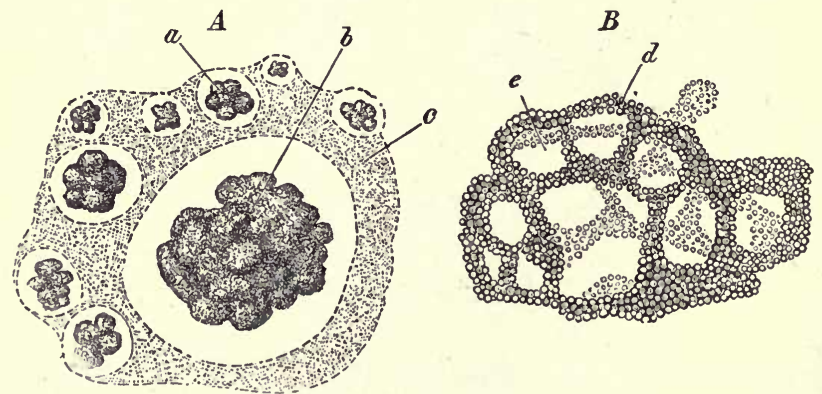

Fig. 8. - Ascococcus (after F. Cohn), enlarged 65 times, showing, inside the gelatinous colony, segmentation into small $(a)$ and large $(b)$ spherical colonies of cocci which appear to lie in chambers. $B$, The Clathrocystis form of Beggiatoa roseo-persicina (after Zopf); the large chromatia (monads of earlier authors) just visible ; magnified I : 250 .

the bacteria which produce propionic acid. In the latter instance these irregular forms appear

${ }^{1}$ Ber. d. Deutsch Bot. Ges., 1893. 
when fermentation is at its height. In such cases they may be regarded as true developmental forms. In other species such an appearance foreshadows spore-formation. Even
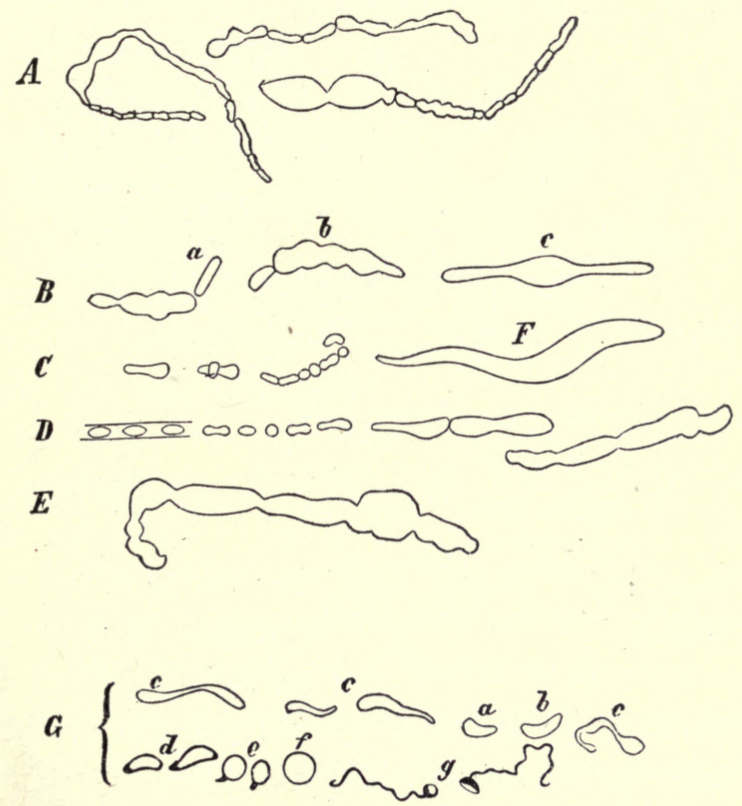

Fig. 9.-Degeneration forms. $A$, lactic acid bacteria after Maddox. B, Clostridium polymyxa, after Prazmowski. C. Bacterium Zopfii, after Kurth. D, B. Subtilis and E, B. anthracis, after Buichner. $F$, Vibrio rugula, after Warming. $G$, V. cholera asiatica, after van Ermenghem and Hueppe.

more frequently such forms appear as the forerunners of death, - as degeneration forms due to the swelling up of the membrane (Fig. 9). Death is also sometimes accompanied by 
granular disintegration of the cell-contents (Fig. IO).

If the outer cell-membrane swells up and becomes gelatinous, an envelope or capsule is formed. The gelatinous scum or zoöglœa that
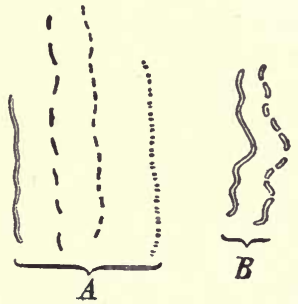

Fig. Io.-Granular disintegration of bacteria. $A$, supposed typica disintegration of a spirochate from swamp-water, first into longer, then into shorter, rods, and finally into little spheres (after Zopf). B, ordinary breaking up into segments, and $C$, granular disintegration of comma bacilli (after Hueppe).

spreads over the surface of decomposing fluids is composed of such a film of bacteria held together by their gelatinous envelopes. Ins id e the mass an orderly arrangement of cell groups may exist. Pellicles may be formed on the surface of fluid and solid media, and these may be thin or thick, smooth or corrugated; in the interior of fluids the growth may be, globular, ramifying or in grape-like clusters. The zoöglœæ or colonies upon certain solid nutrient media like gelatin, agar-agar and potato are especially characteristic (Fig. I I). The shape of the colony and the kind of development vary according to the chemical and physical conditions that affect nutrition but under similar conditions are always approxi- 

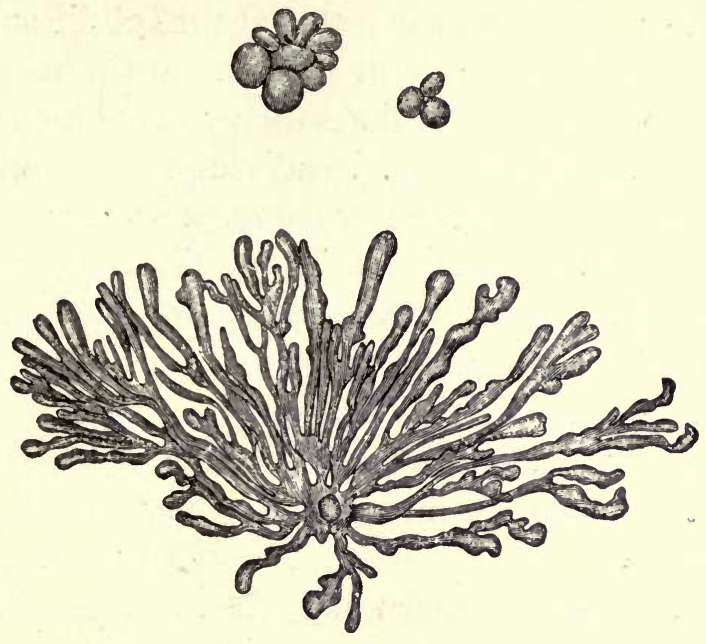

Fig. II.-Zoöglœe of a rodlike form found in the bulbæ of pemphigus acutus (after Demme). Agar culture, natural size.

mately the same, so that the morphological characters of a colony can be advantageously used in the recognition of bacterial species.

One of the greatest services that Koch has. rendered to bacteriology is his invention of methods of pure culture, by means of which such isolated colonies, originating from a single germ, can be cultivated at will and obtained free from any admixture with germs of other kinds. Such pure cultures, reared under perfectly similar conditions, always agree in form and physiological action at any given stage. But this is not real constancy. The similarity does not depend upon the invariability of the 
bacteria, but upon the fact that the conditions of life suffer no alteration. If the conditions fluctuate, the bacteria will also vary in form and in physiological activity. Individual bacteria as well as their zoöglœæ or colonies always adapt themselves to the "milieu." The constancy which Koch's method revealed was not one of true permanence of species, but rather one of permanence of varieties due to station. As one emigrant in his new home clings strenuously to the manners and customs of his fatherland while another quickly forsakes them, so some species of bacteria transplanted into changed conditions of life preserve their original characteristics, while others part with them. It is possible by means of pure culture to obtain proof of the validity of the principle formulated by L. v. Buch and Moritz Wagner, who maintained that by subjecting individuals to different conditions of life, new species might be produced.

Bacteria can be separated readily into genera and species, although earlier observers assumed that these organisms possessed an almost limitless variability of form and of physiological activity. There are certainly some species which pass through comparatively few forms, although others are protean. Of a kindred order of facts is the observation 
that individual forms are at times tolerably constant, but frequently change somewhat under changing external conditions. The existence of rigid form-species, which not only the earlier observers, but even Cohn, Schröter and Koch assumed, can be upheld no longer. The adaptability of bacterial forms to changing conditions of nutrition is not so boundless as Naegeli and Billroth supposed, but it is considerably greater than was once held to be compatible with the conception of the existence of constant species.

In the first instance form-species or formgenera were recognized and these were named after the most prominent forms. It was in accordance with this tendency that Ferdinand Cohn, turning the older names to good account; applied the generic title Micrococcus to the coccus form, Bacterium to the short rods, Bacillus. to the long rods, and Vibrio, Spirochate and Spirillum to the various spiral forms. These designations did not really serve to distinguish a single species, and Naegeli and Koch added more confusion to a matter which was in itself simple. The name Bacillus was applied by these investigators not to long rods but to a genus or species whose most " essential " form was a long rod. What else characterized it, whether it changed its form or whether it pro- 
duced spores, were in the first instance matters that were regarded with indifference.

In order to determine truly natural genera and species, more must be known than the supposed "typical," " constantly recurring," or "principal" forms. Something additional has been obtained through our knowledge of flagella. (Fig I2.) Many cells without membranes, such as amœbæ, have, as is well known, the power of sending out protoplasmic processes quite at will, as in the so-called pseudopodia. The term cilium or flagellum is used in a more restricted sense than pseudopodium, and is applied to the delicate threads of protoplasm which are extended through definite openings in the cell membrane and which retain a connection with the cell-contents. The flagella of bacteria, which were discovered by Ehrenberg, are now known to be appendages of the membrane, and their connection with the cell protoplasm has not been accurately determined; they seem, however, to be true organs of locomotion. The possession of cilia brings bacteria into closer relation with the groups of monads and flagellates, organisms which are regarded as animals. A. Fischer has attempted to make use of the flagella for purposes of diagnosis. He lays stress upon the presence or absence of these structures, and their occurrence singly or in 
1.

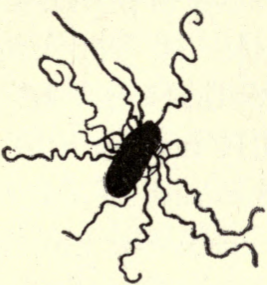

3

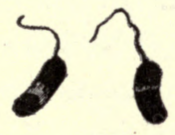

2.

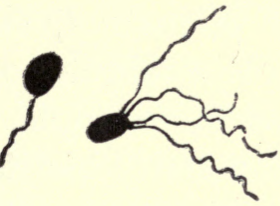

4.
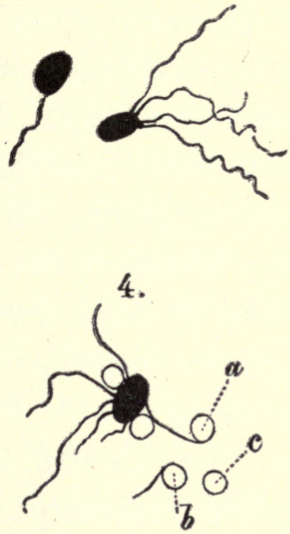

.

5.

6.
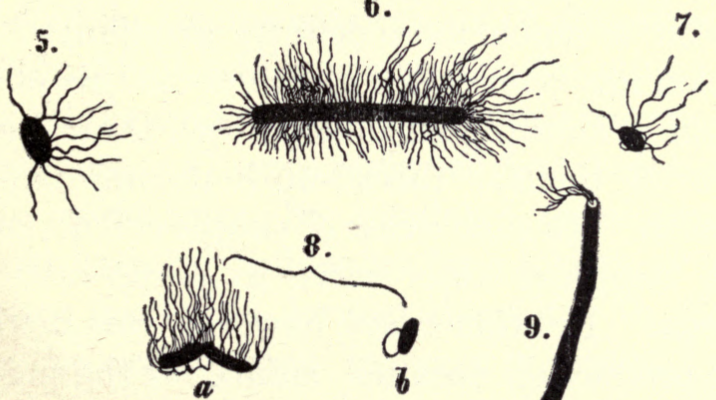

9.

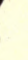

Fig. 12.-Flagella.

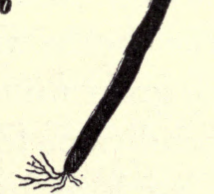

I, B. subtilis ; 2, B. termo; 3, Cholera bacteria. 4, Typhoid bacteria showing rolling up of flagella $(a)$; free flagella, partly $(b)$ and wholly $(c)$ coiled. I-4 enlarged about 1500 diameters (after A. Fischer). 5, 6, Protcus vulgaris after micro-photographs by Fraenkel and Pfeiffer; I500 diameters. 7, Swine plague bacillus. 8, Potato bacillus. 9, Spirillum serpens after microphotograph by Neuhauss (I : I000). 
tufts at the cell poles, or distributed over the whole cell body. Such emphasis is provisional, indeed premature, since little is yet known about the conditions of cilia formation. $M$. prodigiosus, for example, is usually non-motile, but is occasionally motile by the aid of flagella; the cholera germ, which is actively motile in ordinary bouillon, becomes motionless in bouillon to which sugar has been added.

Far more important as an aid to systematic classification are the facts afforded by spore-formation. In multiplication by simple division a complete rearrangement of the cell-contents takes place, and the granules in the protoplasin exhibit a much more definite grouping. Attention has been called elsewhere to this observation as showing an analogy with the arrangement of nuclear thread-work during mitotic division. In such a case of simple cell division, both daughter cells serve to perpetuate the species. In other cases, however, this method of reproduction does not suffice for the preservation of the species and the ordinary vegetative cells die in great numbers under the natural or artificial conditions to which they happen to be subjected, such as light, heat, dryness, chemical influences and competition with microbes of their own or other species. In this event, certain cells that are more resistant take charge 
of the perpetuation of the species under the guise of a resting-stage or spore. Cohn was the first to observe that sometimes the single cells that become detached from a filamentous bacterium or that are set free by the breaking up of the filament, do not possess the character of ordinary vegetative cells but rather resemble the gonidia, conidia or spores such as are found in some algæ or moulds, and Hueppe and De Bary subsequently showed that in many bacterial species single members of a chain may acquire the resistant properties and the function of the resting-stage. For distinction these were called arthrospores (Figs. 3, I3, I9). It appeared in some instances as if almost any individual cell, while not unlike the others in form, might under certain conditions become an arthrospore. Hueppe observed that such a cell would sometimes be insulated or protected against harmful influences by a mantle of the adjacent dead cells formed about it. In other cases the arthrospores increase in size and acquire a compact membrane, as happens also in some algæ. In some leptothrix-forms the gonidia are found in thickenings of the sheath which must therefore be considered as the spore-bearer or sporangium.

True arthrospores are spheroidal in form, but this fact must not lead us to confound them 


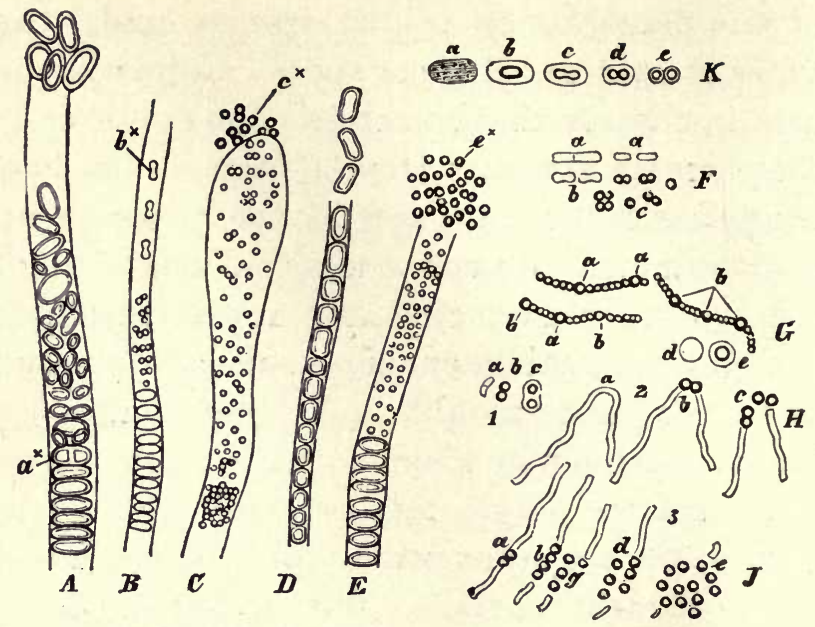

Fig. 13.-Gonidia and Arthrospores.

$A-E$. Crenothrix, the ends of the filaments are the places where spores are formed-the sporangia. $A$ and $D$, macrogonidia : the segments of the filament are undivided or broken up only into quite large pieces $(A, a)$. $B, C, E$, microgonidia formed by repeated division and subdivision of the segments : after expulsion from the filament zoogloa forms $(C, C$ and $E, c)$ may occur. These microgonidia, and in Beggiatoa the macrogonidia also, may at times develop flagella and become swarm spores. $K$, the formation of arthrospores in rods from direct observation (Hueppe); the previously homogeneous protoplasm becomes granular $(a)$, contracts $(b)$, divides $(c, d, e$,$) into two highly refractive$ arthrospores, each of which is surrounded by a membrane $(e)$. $F$, arthrospores of $B$. Zopfii, after Kurth. $G$, Leuconostoc, after van Tieghem. $H$ and $f$, comma bacilli, after Hueppe; these form $(\mathcal{F} . d, e)$ zoogloe composed of coccus-like arthrospores.

with the polar granules produced by plasmolysis. It must be remembered also that the gonidia of the filamentous bacteria may often form zoöglœal masses of coccus-like forms. In such gonidia flagella have been sometimes observed, showing an affinity to real swarm-

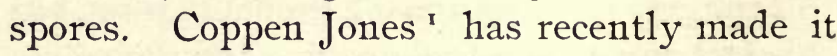
1 Centralbl. f. Bakt. xvii, I895, I. 
appear probable that some organisms that are generally supposed to be bacteria, such as the so-called tubercle bacillus, exhibit a type of spore-formation which is homologous with the chlamydospore formation of true moulds, such as Mucor (Fig. 20).

In addition to the true bacteria, or to those organisms that up to this time have gone under that head, which propagate by arthrospores in the narrower sense, or by gonidia like some kinds of fission-algæ, or by chlamydospores after the manner of some kinds of moulds, there are some bacteria which reproduce in another and characteristic fashion, namely by means of endogenous spores or endospores. Endospores were discovered by Perty in 1852 (Fig. I4). It is necessary to distinguish two

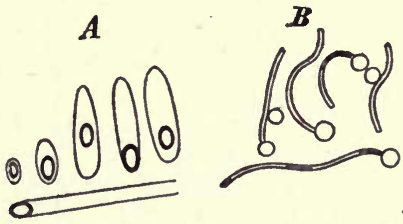
kinds of endosporeformation which, however, are connected with one another, through intermediate forms. In bacteria of Fig. I4-The endospores of bacteria (first seen by Perty).

A. Sporonema ; belongs probably to the swamp bacteria ; shows Klein's second type of spore formation.

B. Spirillum undula, perhaps the same as Prazmowski's Vibrio rugula.

the first and more comprehensive type, a dark speck appears in the cell-contents after-but sometimes without-preliminary granulation. 
This speck becomes gradually larger and reaches its ultimate size at the expense of the

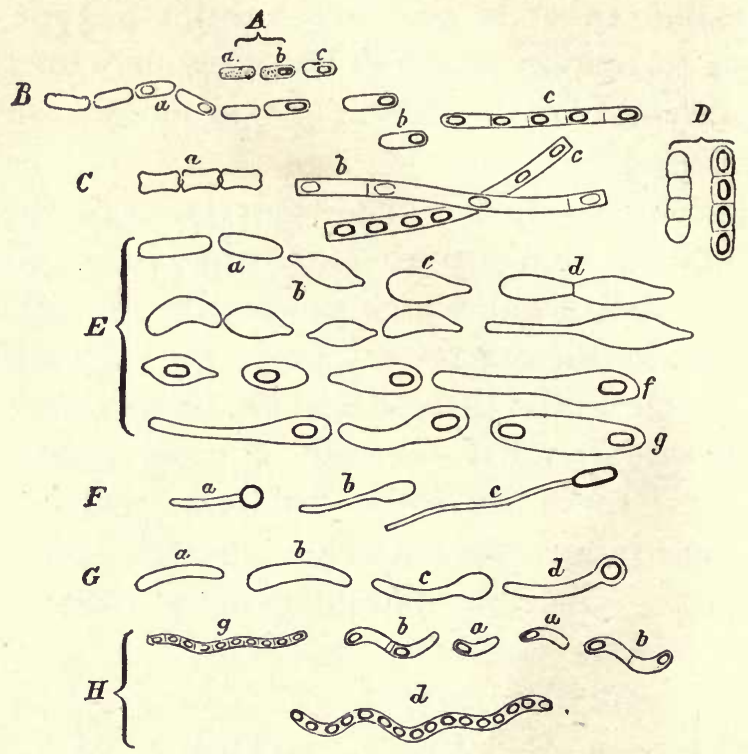

Fig 15.-Endogenous Spores and their Manner of Formation.

$A$, in the first type the previously homogeneous protoplasm becomes granular $(a)$ gathers together in one place $(b)$ and finally $(c)$ is wholly included in the spore. $B, C, D$, true bacilli in which spore formation occurs without altering the shape of the rod. $B, B$. subtilis; $C$, anthrax bacillus. $D, B$. megatherium. E, spindle-shaped or club-shaped rods, showing changes of form preliminary to spore formation. In $E$, $f$, only one of two adjacent cells has become spindle-shaped. In $g$ it appears as if two spores lay in a single cell; as a rule, however (as in $d$ ), such an appearance is in reality due to a close connection of two cells. E are forms of Clostridium butyricum, $\mathrm{Cl}$. polymyxa (partly after Prazmowski). $F$, Plectridium forms, $a$, Tetanus bacteria; $b$ and $c$, Bacteria from putrefying fluids. $G$, spore formation in the genus Vibrio (V.rugula) after Prazmowski. $H$, endospores in Snirillum after van Tieghem; $a, b$, Spirillnm amyliferum; $d, g$, Sp. serpens (?)

cell-protoplasm. In a colony of bacteria different stages of spore-formation may be simul- 
taneously observed (Figs. 6, 7, I5, 18). By contraction of the protoplasm and decrease in the quantity of water contained, the spore comes to have a highly refractive appearance. Its body becomes limited externally by a dense and rapidly formed spore-membrane. The motile forms become motionless before sporeformation. It is a matter of secondary significance that sometimes all the cell-protoplasm is converted into a spore, and that some times a portion remains outside. It is likewise of subordinate importance whether the spore be round, oval or beanshaped, whether it is forméd at the middle of the cell or at the end, whether the cell pre-

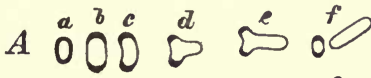

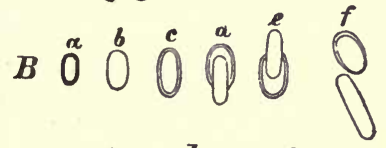

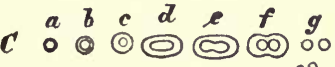

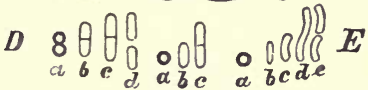
Fig. 16.-The Germination of Spores.

$A, B$. subtilis after Brefeld; the spore membrane splits open on one side, the rod grows, however, in the direction of the long axis of the spore. $B$, Clostridinm butyricum, after Prazmowski; the young cell grows from the pole. In the endospores $A$ and $B$ the emnty spore membrane is left behind on germination.

C, Gonidia of Leuconostoc after van Tieghem; the membrane of the arthrospore $a$ becomes swollen and the arthrospore grows like a vegetative cell. $D, B$. $Z$ opfi $i$ after Kurth. $E$. Comma bacilli after Hueppe. serves its form or suffers a preliminary swel1ing at the place where the spore is to form. In the germination of spores, likewise, similar small and inconsiderable differences make their appearance (Fig. I6). These characters 
are in certain cases very important as aids to diagnosis, but are not so essential as the difference shown by the second type of endospore discovered by Peters and L. Klein. In this

1.

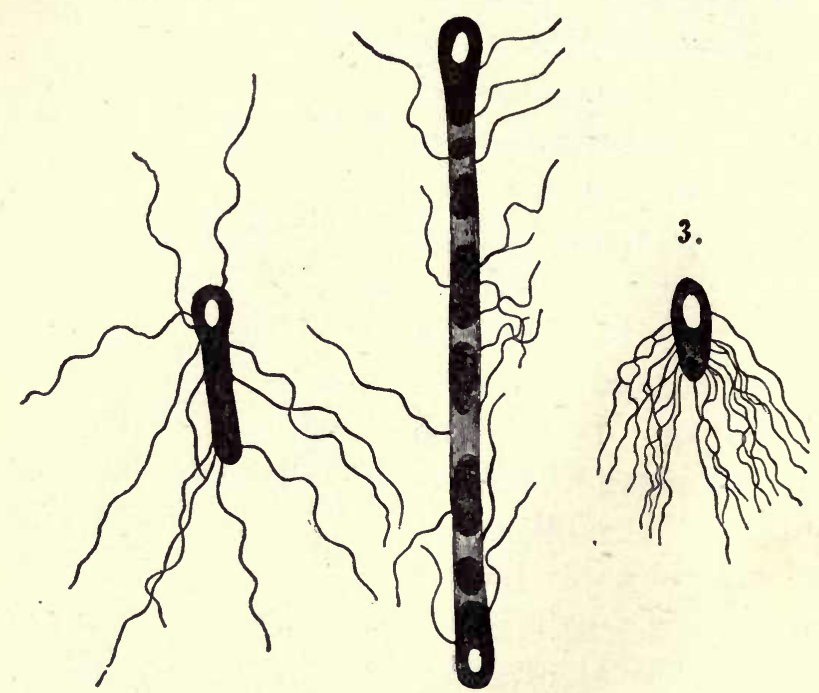

Fig. I7.-Endospore formation in flagellate, actively motile bacteria ; second type of spore formation (according to Klein) in bacteria from stagnant water.

I, B. Solmsii with protoplasm disintegrated by plasmolysis; in the lighter portions the protoplasm is drawn away and the membrane alone shows.

2, B. paludosum.

3, Ciostridium butyricum.

I-3 after drawings by A. Fischer, about I : 2000.

(Fig. I7), there is an initial separation of the protoplasm into a spore-forming and a spore-free portion, so that from the beginning the spores

1 Ber. d. Deutsch. Bot. Ges. 1889, vii., p. 57. 
are sketched out in their final size and shape and do not, as in the first type, gradually increase their substance at the expense of the rest of the protoplasm. During the process of maturation, the nutrition of the spore-rudiment is provided for by the rest of the cell-protoplasm, and, as the cilia bear witness, the movements of these species do not cease during spore-formation. Endospores are most common among the rod-bacteria, but they have also been positively observed in coccus and spiral forms.

Pasteur succeeded in suppressing spore-formation in the anthrax bacillus by subjecting it to a temperature of between $42^{\circ}$ and $43^{\circ}$. Roux ${ }^{\mathrm{I}}$ and Phisalix ${ }^{2}$ obtained a similar result by the addition of carbolic acid to the culture medium, a simultaneous weakening of the physiological activities of the germ occurring in both cases. The hereditary repression of such an important morphological characteristic as spore-formation was, however, not effected.

A mode of spore-formation similar to that of bacteria has as yet been observed only among some monads and flagellates-as in the so-called cyst-formation, for example, in

1 Ann. de l'Inst. Pasteur, I890, p. 24.

${ }^{2}$ Le Bull. méd., I892, No. 35; La Semaine méd., 1892, No. 40. 
Monas (Spumella) vulgaris and in Chromulina.

Aided by the foregoing facts, we may attempt to advance beyond Cohn's "form-genera " and "form-species" of bacteria to a conception of natural genera and species. According to Hueppe and De Bary, the endosporous bacteria must be fundamentally separated from the arthrosporous. For the sake of clearness, let us cite some examples. The specific disease germs found in anthrax, typhoid fever, diphtheria and tuberculosis have the form of rods and are consequently known in medical literature as Bacilli. But the anthrax rods, in the light of their whole life history, belong to a species that forms filaments and produces endospores of a well-known and characteristic kind; the bacteria of typhoid fever and of diphtheria form no endospores, and the tubercle rods probably form chlamydospores. According to Cohn's earlier view the genera Bacillus and Bacterium were to be distinguished only by the length of the rods, but according to his later conception the difference lies not in the dimensions of the rods, but in the fact that the one forms endospores while the other does not. In accord with this terminology, therefore, the anthrax rods belong to the genus Bacillus, the typhoid and diphtheria rods to 
the genus Bacterium or Arthrobacterium, and the tubercle rods are not true bacteria at all, but a parasitic form of the tubercle mould.

A step further indeed may now be taken. The name Bacillus may be limited to that genus in which the rods undergo no change in shape during spore-formation, and we may use the term Clostridium for that genus in which the rods are spindle-shaped or become spindleshaped during spore-formation, and designate as Plectridium that in which the cells are shaped like a drumstick or become so shaped through the development of endospores. With reference to spore-formation, therefore, there are among the rod bacteria three genera of endosporous and one of arthrosporous bacteria. These may be still further analyzed into subgenera if we take into consideration the form of the spores, or, as Fischer has suggested, the character of the flagella.

Among the spiral bacteria Cohn constituted the form-genera Vibrio, Spirochate and Spirillum merely upon the basis of the form of spiral. I would establish here a division into natural genera, calling those spirals which do not change in shape during endospore-formation Spirillum, and applying the name Vibrio to those that become swollen in some one place when endospores are formed, 

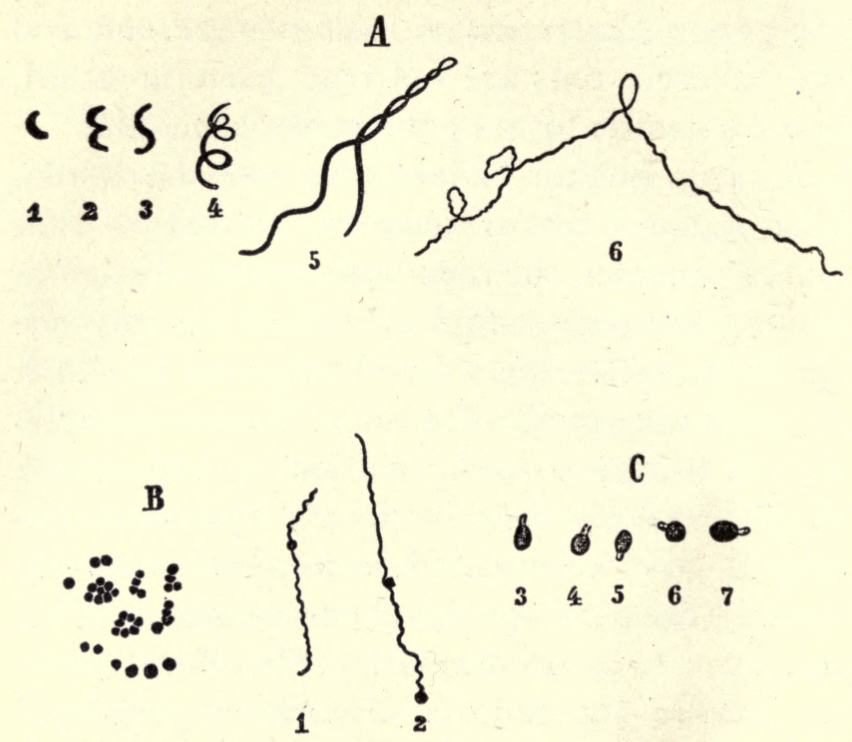

Fig. 19. Cholera asiatica.

$A$, Comma bacilli, I-4 after drawings ; 4 , twisted coil, so-called Spirodiscus, (about I : I200); 5, 6, spiral filaments with spirulina twistings (after photographs, about I : 700).

$B$. Ripe arthrospores (after photographs), about I : Iooo.

C. I and 2, Arthrospores in filaments (after van Ermenghem, from photograph), about $I: 700$.

3-7, germinating arthrospores (after photographs by Pertik, I : 1200).

and Spirochate to those that form arthrospores (Fig. I9). Under this nomenclature, the specific germ of Asiatic cholera would be designated as Spirochate, although in medical literature the three names, Vibrio, Spirochate and Spirillum are used interchangeably and quite arbitrarily. The older usage has no harmful effect if only there is a clear understanding 
of what is really meant, but it has had a somewhat cramping influence upon the development of bacteriological nomenclature, and its disadvantages may still be frequently perceived.

The statements thus far made might well lead to the conjecture that the genera hitherto established fall short of expressing all the known facts. It is clear, in fact, that all the essays at classification made by F. Cohn, J. Schröter, Zopf, De Bary, Hueppe, Migula and $\mathrm{A}$. Fischer have their defects; but botanists are almost unanimous in accepting the essential features of the position taken by Cohn, De Bary and Hueppe. Much would be gained, therefore, if those physicians and technical workers who have to do with bacteriology would keep in mind the following table of orienitation which at least excludes gross errors :

I. Coccacea, producing in the vegetative state coccus forms.

I. Micrococcus, characterized by irregular disposition of the cells and cell-groups; endospores as yet unknowi (Fig 8).

2. Sarcina, forming tetrads and balelike packets of cells ; endospores unquestionably observed (Fig. 7).

3. Streptococcus, forming spores; arthrospores unquestionably observed, endospores doubtful (Fig. 4). 
II. Bacteriacece, producing in the vegetative condition rod-forms which are grouped in chains or filaments.

I. Arthrobacterium, forming arthrospores, or Bacterium, forming no endospores (Fig. 3).

2. Bacillus; with endospore formation (Fig. 18). Sub-genera $a$. Bacillus; straight rods.

b. Clostridium; spindle-shaped rods.

c. Plectridium; drumstick-shaped rods.

III. Spirobacteriacea, in vegetative condition forming short curved rods (comma-shaped, S-shaped) which may elongate into spiral filaments.

I. Spirochate, without endospores and with arthrospores (Fig. I9).

2. Vibrio, with endospores; the cell changes in shape during spore-formation.

3. Spirillum, with endospores; the cell does not change its form.

IV. Leptothrichea, forming in the vegetative stage rods which unite in filaments.

I. Leptothrix is distinguished from the filamentous chains of arthrosporous bacteria by the fact that the filaments are differentiated into base and apex.

2. Beggiatoa, filaments without sheath; the cells contain sulphur granules (Fig. I, $I$ and 5).

3. Phragmidiothrix; the threads are segmented into shallow disks which may fall apart into half-disks, quadrants and finally spheres.

4. Crenothrix; the thread possesses a sheath in which there is usually a deposit of iron (Fig. 13).

V. Cladothrichea; the vegetative cells belong to the rod-forms, the rods have a sheath and show branching.

Cladothrix (Figs. 5 and 2 I). 
1.
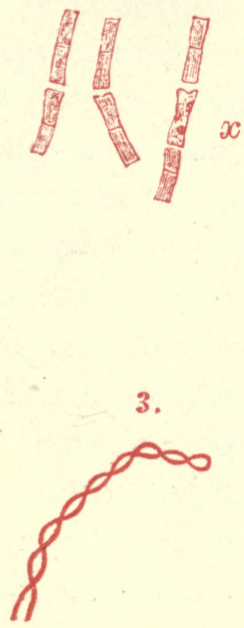

2 .

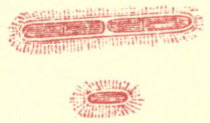

4.

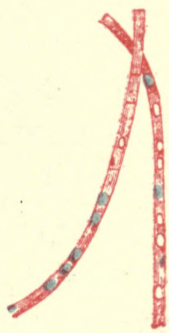

Fig. 18.-Anthrax bacteria.

I. From spleen pulp, (I: I 200).

2. From the blood, showing possession of capsule, (I:IO0O).

3. Edge of a culture showing filamentous windings of the so-called spirulina type, (I:300).

4. Spore formation, $(\mathrm{I}: 500)$. 

Assuming that life originated upon our planet, the first living things must have been so organized that their metabolic processes were more like those of plants than of animals ; in a word, the primitive organisms must have been holophytic, since to holophytes alone are saprophytes able to attach themselves. It is therefore suggestive that, besides physiological correspondences to be noted later, the structure of the gonidia-forming or arthrosporous bacteria shows a progressive differentiation or evolution from the simplest bacterial forms and species through to the Cyanophycea, a group of bluegreen algæ which may be regarded as an undeveloped branch of the plant kingdom. On the other hand, the formation of endospores and the possession of flagella are facts that indicate phylogenetic relations with the monads or flagellates, a group usually reckoned as animals. Physiologically also a double affinity is mani- . fested, since bacteria display almost the same capacity for building up organic substance as for breaking it down.

It was remarked by Cohn that a complete parallelism existed between the genera now regarded as arthrosporous bacteria and certain groups of the fission-algæ (Spaltalgen). Cohn, indeed, already departing from his purely morphological standpoint, established two 
groups of distinct phylogenetic value when he placed zoöglœa-forming bacteria along with zoöglœa-forming schizophytes in one group, and filament-forming bacteria with filament forming algæ in a second and related group. These distinguishing marks, however, as Zopf proved later, were not natural ones, and the stronger emphasis subsequently laid upon fructification yielded the first hint of the abovementioned affinities. But Cohn, understanding the close phylogenetic relations, was right in some details and correctly ranked Leuconostoc with the bacteria, Nostoc with the Schizophytes, Beggiatoa with Oscillaria, Crenothrix with Chamasiphon and Cladothrix with Tolypothrix. Botanists and zoölogists have in general assented to the view taken by Cohn, Hueppe and De Bary according to which two groups phylogenetically distinct are united under the name of bacteria.

Several years ago Brefeld asserted that those organisms passing under the name of yeasts, budding-fungi or Saccharomyces did not form a true natural group but were specialized forms of various species of moulds. Hansen maintained, in opposition to this, that the species of Saccharomyces that formed endospores were to be regarded as an independent natural 
group. Lately Juhler ${ }^{\mathrm{I}}$ claims to have discovered that the mould concerned in the sake fermentation develops bud-like forms which produce endospores, and A. Jörgensen ${ }^{2}$ maintains that one of the wine-yeasts, a true endospore-forming variety, is merely a stage in the life-cycle of a mould, which, upon alkaline media, grows in the semblance of the mould Chalara, and upon acid media in that of Dematium. In similar fashion L. Klein looked upon the arthrosporous bacteria as degenerate Schizophytes, as Cyanophycee indeed, which had lost their chlorophyl and become saprophytic. It is true he abandoned this view after Hueppe had demonstrated the ability of colorless microbes to assimilate carbon dioxide and thus to exist like true plants, a point to which I shall return presently.

There are cogent reasons for accepting the opinion that still a third group of quite different phylogenetic value should be recognized among the organisms hitherto classed as bacteria. In cultures of the ray-fungus true coccus and rod-forms occur which appear like undoubted bacteria. Since, however, the method of branching of the filaments is not

1 Centralbl. f. Bakt. Abth. II., I., 1895, p. 16, p. 326.

${ }^{2}$ Centralbl. f. Bakt. Abth. II., I., I895, p. 321. See also Klöcker and Schiöning, Annal. de Microg., IX., I897, Nos. 6-8. 
like that of Cladothrix, the Actimomyces fungus must after all be regarded as a mould. Till recently the tubercle bacillus was regarded as an especially typical bacterium, and when stained differentially, the shining red band stood out in fine contrast with the blue background, a most beautiful example of a bacillus. But Roux, Nocard and Metschnikoff, as well as more recently E. Klein and Maffucci, observed that the tubercle bacilli obtained from cases of fowl tuberculosis exhibit a sort of branching; and Metschnikoff, laying emphasis upon the filament-forming character of the organism, placed it with the Leptothrichee or Cladothrichee and called it Sclerothrix. For some time evidence has been accumulating that the opinion of Koch, who had regarded the organism as forming endospores and had hence correctly conferred upon it the name of tubercle bacillus, and his corresponding schematic figure were erroneoús. Upon the basis of further investigations which revealed branching even in the microbe of mammalian tuberculosis,-investigations supplemented by my pupil Fischel,-I have arrived at the definite opinion that the tubercle bacillus is the parasitic growth-form of a pleomorphic mould and is not a true bacterium at all, but, in respect to its morphology, is closely 


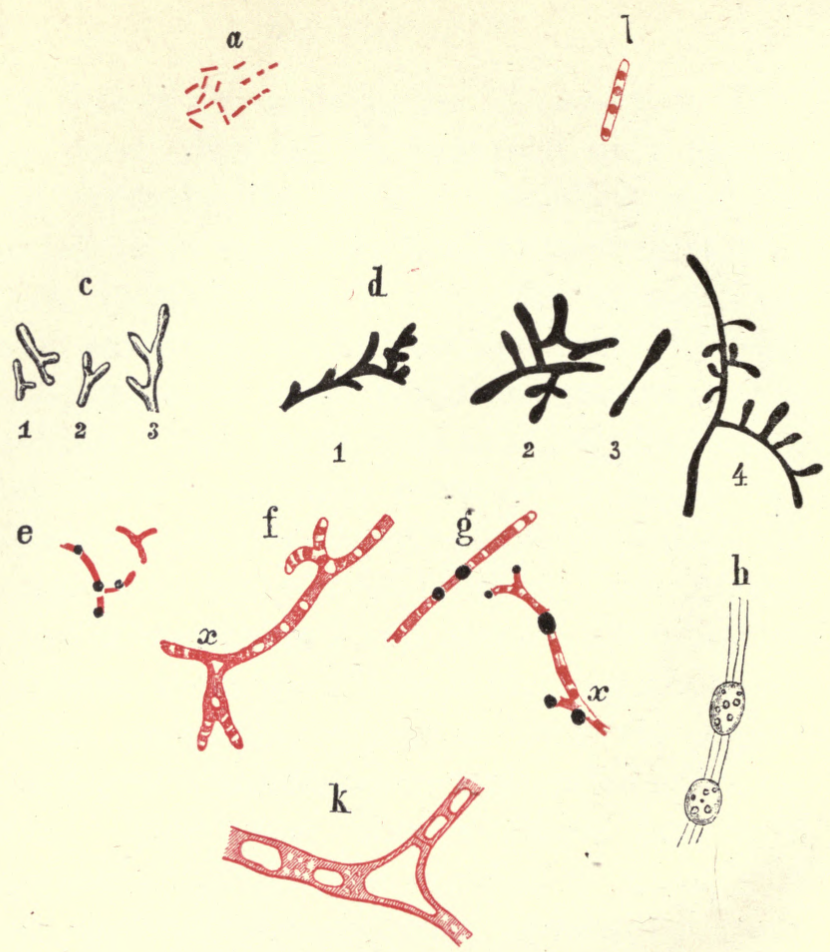

Fig. 20.-The Germ of Tuberculosis.

$a$, ordinary forms found in cultures and sputum (after photographs), about $\mathrm{I}: 900$.

$b$, Shows plasmolyzed cell contents, so-called coccothrix - forms, ( I : 1250).

$c$, portion of the edge of a fresh culture of the germ of mammalian tuberculosis, unstained, (about I: 2000).

$d$, stained, I-3, after photographs by F. Fischel, I, the germ of avian tuberculosis from glycerin agar, 2, 3, the germ of mammalian tuberculosis from egg cultures; 4 , mammalian cultures from glycerin agar, Hayo Bruns. (I-3, about I: $1200 ; 4$, I: 1000 ) $e, g, h$, Formation of Chlamydospores; $e$, mammalian tuberculosis (after photographs, I: 9000); $g$, from sputum (drawing after Coppen Jones, I: I 250); $h$, chlamydospores of Mucor for comparison; $f$, branching of filaments (after Coppen Jones), I: I250; at $x$ it can be seen that the vacuoles extend from the main stem into the side branches, as in $k$, a hypha of Penicillium, thus showing the existence of "true" branching. 
related to the ray-fungus. Coppen Jones has subsequently confirmed these results, and has made it appear likely that this mould possesses a kind of fructification resembling chlamydospore-formation. Its mode of branching also speaks for its mould nature (Fig. 20). In spite of these facts, physicians have continued to call this organism the tubercle bacillus. This would be a matter of indifference if it were not for the unavoidable confusion brought about by the persistence likewise of Koch's totally inaccurate figure. But a gradual change of opinion seems to be coming about, and very recently Hayo Bruns ${ }^{1}$ and Semmer ${ }^{2}$ have confirmed the pleomorphism of the tubercle bacillus. ${ }^{3}$

Occasionally branching is observed, too, among organisms which are presumably true bacteria, as Metschnikoff has discovered in the case of the comma-bacilli of Asiatic cholera, C. Fränkel in the so-called diphtheria bacilli and Semmer in the bacteria of glanders which, as arthrosporous species, do not belong at all to the bacilli. Eijkman ${ }^{4}$ has found branched bacteria in the molasses fermentation of rice (Fig. 22). Up to the present it has not been

${ }^{1}$ Centralbl. f. Bakt. XVII., 1895, p. 817.

2 Deutsche Zeitschr. f. Tiermedizin, XXI., p. 212.

${ }^{8}$ See also Marpmann, Centralbl. f. Bakt. XXII., I897, p. 582.

4 Centralbl. f. Bakt., XVI., p. 97. 


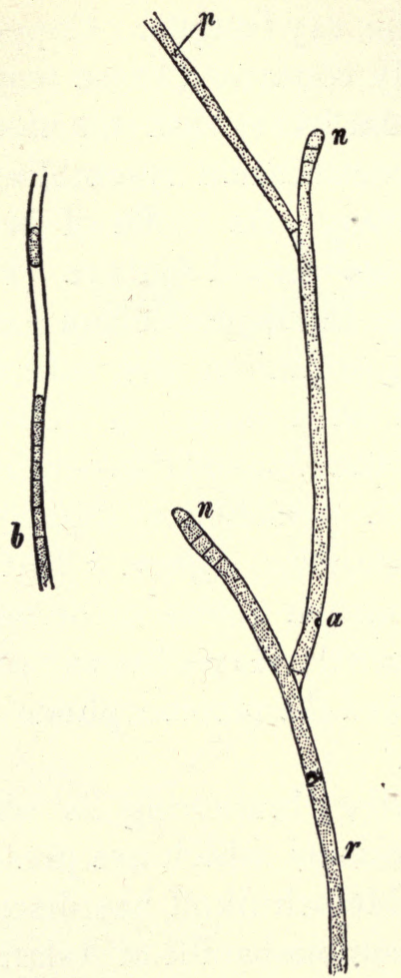

Fig. 21.-Cladothrix dichotoma.

False branching ; the original direction of growth corresponds to the line, $r, a, p$; by the pushing of cells to one side and their subsequent growth the branches, $n, n$, arise ; at the apex of these the structure is plainly seen to be that of a chain of cylindrical cells. The false branching is a special form of branching. $b$, a piece of a filament with distinct segmentation; in the upper part, the sheath is nearly emptied of cells. (Drawing after De Bary) I : 600 .

determined whether the branching is of the same type as the pseudo-branching of the $\mathrm{Cla}$ dothrichea, i.e., of the pleomorphic arthrospo- 
rous bacteria, or is like the true branching of moulds. Schottelius ${ }^{\mathrm{I}}$ observed on certain occasions a cell division so irregular in character in the "miracle bacteria" as at once to suggest budding of a torula or saccharomyces nature, and Wood found a torula-form among anthrax bacilli that were shut out from free access

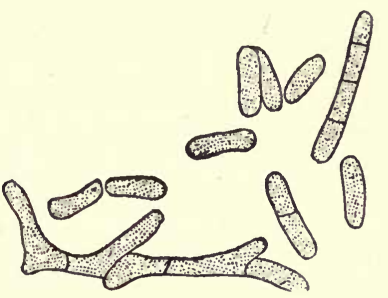

Fig. 22.-Bacillus from molasses fermentation occurring in the manufacture of arrack in Batavia (after Vordermann and Eijkman).

of air, without however being able to initiate development with it. Finally Koch and Hosaeus ${ }^{2}$ have discovered a kind of bacterium with a gelatinous stalk which reminds one of a diatom (Fig. 23). The foregoing facts clearly demonstrate that the usual designations "bacteria" and "bacteriology" are not adequate to represent correctly and scien-

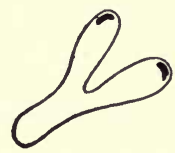
tifically the actual situ- Fig. 23.-B. pediculatum from ation.

\section{The complicated}

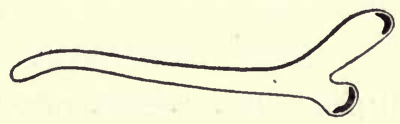
"frog-spawn" of sugar manufactories (after A. Koch and H. Hosaeus).

structure which Ehrenberg claimed was to

1 Festschr. f. A.v. Kölliker, Leipzig, I887.

${ }^{2}$ Centralbl. f. Bakt. XVI., I897, p. 225. 
be found in bacteria and the "infusion animals " ought, in my opinion, to have weighed against the doctrine of "spontaneous generation." We are now no longer able to accept Ehrenberg's conception of the structure of bacteria, yet the knowledge we do possess is sufficient to discredit the notion that bacteria can arise by spontaneous generation. The bacterial cell is much too complicated and too far removed from the ideal "simplest cell" to admit of this view. The experiments devised to support the belief in their spontaneous development out of inorganic or altogether lifeless material have moreover always miscarried. The one undeniable fact in the matter is that certain granular protoplasmic elements can outlast the life of the cell.

In this latter category belong especially those effects due to the so-called lifeless ferments or enzymes. The digestive ferments of the higher animals are in the first instance nothing but extruded cell-protoplasm and often appear like a sort of cell-slime. Among bacteria also such ferments occur independently of the life of the cell. Fermentative manifestations, however, constitute only a limited part of the vital phenomena of the cell. The formation of enzymes, outlasting the cell and indeed to a certain degree independent of it, is 
always dependent upon the integrity of the living cell which alone is able to pass on the torch of life in legitimate succession.

Statements about the origin of bacteria from other cells and cell elements through "anamorphosis of protoplasm"-really a sort of modified spontaneous generation-rest upon an error due to the mistaking for bacteria of cell-granules in milk, blood and tissues, as well as of fibrin secretions and artificially altered nuclear elements. Fibrin threads have also been mistaken for the mycelia of moulds. Fokker described the origin of the anthrax bacilli as taking place by " heterogenesis" out of other cells, but Koch proved that elongated cell-nuclei had been mistaken for bacteria. Roy, Brown and Sherrington discovered filaments in the wall of the intestine which they identified as hyphæ of one of the Chytridiacea and believed to be the cause of cholera till $\mathrm{H}$. Kïhne and Hueppe showed that the filaments were not mould-hyphæ at all, but shreds of fibrin. In like manner Lacerda believed that he had discovered the essential element of snake-venom to be micrococci, but Hueppe was able to prove that these supposititious micrococci were granules derived from the glandcells.

The ferments, by virtue of their independ- 
ence of the cells producing them are, so to speak, "active" proteid, a kind of intermediate stage between lifeless "nutritional " proteid and living cells. Active proteid possesses another property which has become recognized through the medium of bacteriological investigation, that, namely, of killing bacteria and influencing the activity of bacterial poisons. This property of "activity" is acquired by virtue of the vitality of the cell, but is to some extent independent; it can outlast the mother cell and may be preserved for some time by the addition of chloroform, carbolic acid, cresol, or toluene, or by careful drying, while heat, light and putrefaction destroy it. It is a fact of interest in this connection that, according to Schoil, such an "activity" which has been removed by heat can be partly restored by purely chemical measures and thus the distinction between lifeless and living, active and passive proteid still further obliterated.

After all is said, spontaneous generation remains up to the present time only an unavoidable general hypothesis. The attempts of Liebig, Thomson, and Helmholtz to refer the origin of life on our planet to importation from other heavenly bodies evades the question and leaves it as obscure as before. In the synthesis 
of proteid substances, we approach the question as we have just seen, from another side and here also bacteriological researches have been of fundamental importance. Indirectly these results perhaps support the theoretical postulate of spontaneous generation since they seem to efface still further the boundaries between animal and plant, the organic and the inorganic. 


\section{CHAPTER II.}

THE VITAL PHENOMENA OF BACTERIA.

IF we accept the nebular hypothesis of the origin of the solar system, we must believe that the first living things developed under conditions which, in respect to temperature, light and atmospheric oxygen, departed widely from those prevailing at the present time. The atmosphere must have been poorer in oxygen, poorer in light and possessed of a higher temperature. In view of this fact, it is interesting to note that among bacteria, species are found that are able to live without free oxygen, without light, and at a relatively high temperature and this to an extent known among no other group of living things.

Anaërobiosis-Relations to Energy.

To the genius of Pasteur we are indebted for the remariable observation that microbes or micro-organisms can live without free oxygen. In life without air - that is to say, without the oxygen of the air-in the absence of this "food 
of life," oxygen is taken from chemical compounds which, in consequence, suffer disintegration and rearrangement of their parts. Pasteur observed this phenomenon of anaërobiosis first in fermentations, thereby renewing acquaintance with a process previously known to some alchemists, and described as a "fermentatio clausa." It is really a question of the decomposition of very unstable bodies, a process resulting from the disturbing influence of molecular movements imparted to these bodies by the substances exciting fermentation.

In the chemical building-up of the bodysubstance of living things we can distinguish several groups of phenomena: polymerization, a sort of doubling up of a simpler compound; synthesis, a union of different kinds of simple compounds into one more complex substance; formation of anhydride, by which new substances arise from a compound througl the loss of water; and reduction or loss of oxygen, which is brought about especially by the entrance of hydrogen into the molecule. The breaking down of organic bodies in and through the action of living things takes place through the loosening of the bonds of polymerization; through hydration or entrance of water into the molecule; and through oxidation. 
The following examples will make these processes clear. I shall at first use intentionally the empirical formulæ, taking no heed of the so-called chemical constitution of the compound, and leaving unconsidered the displacement of atoms and atomic groups.

Hydration and formation of anhydride:

$$
\begin{aligned}
& { }_{3} \mathrm{C}_{6} \mathrm{H}_{10} \mathrm{O}_{5}+\mathrm{H}_{2} \mathrm{O}=\mathrm{C}_{12} \mathrm{H}_{22} \mathrm{O}_{11}+\mathrm{C}_{6} \mathrm{H}_{10} \mathrm{O}_{5} \\
& \text { starch, water, maltose, dextrine. } \\
& \mathrm{C}_{6} \mathrm{H}_{10} \mathrm{O}_{5}+\mathrm{H}_{2} \mathrm{O}=\mathrm{C}_{6} \mathrm{H}_{12} \mathrm{O}_{6} \\
& \text { dextrin, water, grape-sugar. } \\
& \mathrm{C}_{12} \mathrm{H}_{22} \mathrm{O}_{11}+\mathrm{H}_{2} \mathrm{O}=\mathrm{C}_{6} \mathrm{H}_{12} \mathrm{O}_{6}+\mathrm{C}_{6} \mathrm{H}_{12} \mathrm{O}_{6} \\
& \text { cane-sugar, water, grape-sugar, fruit-sugar. } \\
& \text { or, milk-sugar, “ " “ galactose. }
\end{aligned}
$$

\section{Conversely :}

$$
\underset{\text { grape-sugar, water, }}{\mathrm{C}_{6} \mathrm{H}_{12} \mathrm{O}_{6}}-\underset{\text { starch. }}{\mathrm{H}_{2} \mathrm{O}}=\underset{\mathrm{C}_{10} \mathrm{H}_{10} \mathrm{O}_{5}}{\mathrm{C}^{2}}
$$

Polymerization and breaking up of polymers :

$$
\underset{\text { formaldehyde, }}{6 \mathrm{CH}_{2} \mathrm{O}}=\underset{\text { grape-sugar. }}{\mathrm{C}_{6} \mathrm{H}_{12} \mathrm{O}_{6}}
$$

Conversely :

$$
\begin{aligned}
& \mathrm{C}_{6} \mathrm{H}_{12} \mathrm{O}_{6}={ }_{2} \mathrm{C}_{3} \mathrm{H}_{6} \mathrm{O}_{3} \\
& \text { sugar, lactic acid. }
\end{aligned}
$$

Decompositions and syntheses:

$$
\begin{aligned}
& \mathrm{C}_{6} \mathrm{H}_{12} \mathrm{O}_{6}={ }_{2} \mathrm{C}_{2} \mathrm{H}_{6} \mathrm{O}+{ }_{2} \mathrm{CO}_{2} \\
& \text { sugar, alcohol, carbonic acid. } \\
& \text { (carbon dioxide). }
\end{aligned}
$$

or,

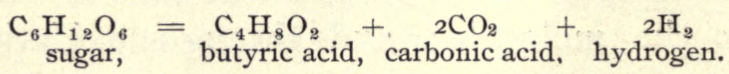


Conversely :

$\mathrm{C}_{2} \mathrm{H}_{5} \mathrm{NO}_{2}+\mathrm{C}_{7} \mathrm{H}_{6} \mathrm{O}_{2}=\mathrm{C}_{9} \mathrm{H}_{9} \mathrm{NO}_{3}+\mathrm{H}_{2} \mathrm{O}$

glycocoll, benzoic acid, hippuric acid, water.

amido-acetic acid,

or gelatin-sugar.

Decompositions and syntheses, with simple displacement or shifting of atoms :

$\mathrm{HCNO}+\mathrm{NH}_{3}=\mathrm{NH}_{4} \mathrm{CNO}=\mathrm{CON}_{2} \mathrm{H}_{4}$ cyanic acid, ammonia, ammonium cyanate, urea.

Conversely :

$$
\begin{aligned}
& \mathrm{CON}_{2} \mathrm{H}_{4}+2 \mathrm{H}_{2} \mathrm{O}=\mathrm{CO}_{3}\left(\mathrm{NH}_{4}\right)_{2} \\
& \text { urea, water, ammonium carbonate, } \\
& =2 \mathrm{NH}_{3}+\mathrm{CO}_{2}+\mathrm{H}_{2} \mathrm{O} \\
& \text { ammonia, carbonic acid, water. }
\end{aligned}
$$

Reductions and oxidations :

$$
\underset{\text { carbonic acid, formaldehyde, }}{\mathrm{H}_{2} \mathrm{CO}_{3}}=\underset{\text { oxygen. }}{\mathrm{OH}_{2} \mathrm{O}}
$$

Reductions, with entrance of hydrogen into the molecule:

$$
\mathrm{CH}_{2} \mathrm{O}_{2}+\mathrm{H}_{2}=\mathrm{CH}_{2} \mathrm{O}+\mathrm{H}_{2} \mathrm{O}
$$

formic acid, hydrogen, formaldehyde, water.

\section{Conversely :}

$$
\begin{aligned}
& \mathrm{C}_{2} \mathrm{H}_{6} \mathrm{O}+\mathrm{O}_{2}=\mathrm{C}_{2} \mathrm{H}_{4} \mathrm{O}_{2}+\mathrm{H}_{2} \mathrm{O} \\
& \text { alcohol, oxygen, acetic acid, water. } \\
& \begin{array}{rrrr}
\text { or, } \mathrm{C}_{2} \mathrm{H}_{4} \mathrm{O}_{2}+\quad \mathrm{O}_{2}= & 2 \mathrm{CO}_{2}+ & +2 \mathrm{H}_{2} \mathrm{O} \\
\text { acetic acid, } & \text { oxygen, } & \text { carbonic acid, } & \text { water. }
\end{array}
\end{aligned}
$$

In the absence of oxygen no oxidation can occur, hence a smaller quantity of energy is liberated. If, for example, r,ooo grams of grape-sugar be burned or oxidized to carbonic 
acid and water, it affords 3,939 heat-units or calories; if, however, it be split into butyric acid, hydrogen and carbon dioxide, it yields only 4I4 calories. One thousand grams of sugar suffices to produce 3,939 calories by means of complete combustion with oxygen, while by means of the above-mentioned decomposition without oxygen 9,5 I4.5 grams are necessary to the production of the same number. The access of pure atmospheric oxygen consequently makes life easy, but is not indispensable. The energy needed for the processes of life can be procured by simple decomposition, by hydration or by loosening of polymerizations ; in none of these chemical actions is access of free oxygen necessary, and all molecular shiftings may take place simply with the help of chemically bound oxygen. If we consider anaërobiosis from the point of view of physics, then, it is seen at once that life is carried on in accordance with the general laws - of energy and that there can be no especial vital force. The maintenance of life without free oxygen depends solely upon the presence or absence of available substances which can be broken up with sufficient ease. The standard of availability, however, is very different for different microbes. Pasteur regarded sugar, Naegeli peptone, and Hueppe true proteid substance 
as suitable pabulum. I have also succeeded in finding available inorganic sources of oxygen, thereby somewhat complicating the problem. Life processes carried on without oxygen do not effect any profound changes in the organic material which is broken up, but, in order that the living organism may obtain the requisite quantity of energy from this mode of life, a proportionally large amount of material must be superficially disintegrated. Therein lies the mechanical or dynamic foundation for the fact that a small quantity of a ferment is able to cause the production of much alcohol, butyric acid or lactic acid, and that parasites which have invaded the living body can generate intensely poisonous substances out of the body-proteids.

In the presence of oxygen the decomposition products that are formed by the attack of anaërobic microbes are further decomposed and oxidized by the aërobes; they are thereby rendered inert and consequently harmless. From alcohol is produced acetic acid and afterwards carbon dioxide; proteid-like poisons are broken up and oxidized into harmless bodies.

Some microbes, the obligatory anaërobes, have adapted themselves to the exclusive use of those compounds from which oxygen can be obtained, and others, the obligatory aërobes, are 
able to live only in the presence of free oxygen. Between these extreme types lie the larger number of species, which can live as well with as without free oxygen according to the nature of food-material present; these are designated as facultative anaërobes or facultative aërobes.

Aërobiosis and anaërobiosis must not be considered ontologically. They are results simply of adaptation to the energetical processes of nutrition. Substances poor in nutritional value may, in the presence of air, yield more energy through oxidation than the richest substance through simple splitting. On the other hand, a material capable of being split up easily may at first, in spite of the access of oxygen, remain exempt from oxidation and only later and secondarily come to be oxidized, for the reason that the quantity of energy yielded by simple splitting is sufficient for the need of the microbe. As a matter of fact, it is possible to accustom obligatory anaërobes to life in the air and air-living bacteria to anaërobiosis. A strict anaërobe, Spirillum rubrum, which came into my possession and which produced its red pigment only in the absence of oxygen, could in a short time be cultivated as an aërobe; the same measures have succeeded with the Actinomyces fungus, and $\mathrm{Kitt}$ has cultivated 
aërobically the obligatory anaërobic bacillus of symptomatic anthrax. I have constrained, on the other hand, the cholera germ to adopt an anaërobic mode of life, and thereby arrived at an explanation of its growth in the intestine and the intestinal walls.

It might be possible, in an extreme case, to bring a microbe, ordinarily causing oxidation, to such a point that, in the absence of oxygen, it would even reduce from the oxides the selfsame body, the power to oxidize which was its first known peculiarity. For example, the same microbes which, in the presence of oxygen, oxidize ammonia to nitric acid might, in the absence of oxygen, reduce the nitric acid to ammonia. I have on hand at present some unfinished experiments to test this possibility. The determining cause in any event lies in the grouping of the atoms in the molecule which, either in the presence of oxygen or in its absence, is torn apart by the disintegrating impulse. This molecular disintegration is not necessarily brought about only by living things; other forms of motion can accomplish the same result. Duclaux obtained by insolation a sort of alcoholic fermentation of sugar, and, according to Ritsert, light and oxygen together effect an oxidation of fat.

In the cultivation of anaërobes upon favor- 
able nutrient material, at first, in spite of the presence of oxygen, products due to splitting are formed, and it is only subsequently that oxidation of these products takes place. For this reason, it is necessary, if one wishes to compel aërobes to grow without oxygen, to work with them in a young condition. Cholera cultures are virulent when young, first becoming impotent through access of air. For the same reason our cultures of pathogenic bacteria upon gelatin, agar, and potato, and in broth, are generally without power to produce disease, since, in consequence of the restriction of metabolic activity to the splitting of certain substances, they have accustomed themselves so thoroughly to a metabolism based on oxidation, that the poisons that were formed in the first instance through decomposition are rendered harmless through the subsequent oxidation. Ultimately, therefore, the formation of these poisons comes to a standstill.

Engelmann ${ }^{\mathrm{r}}$ actually observed that one species of Spirillum had a distinct preference for a certain tension of oxygen and always took up its position between the edge and centre of the drop of fluid in which it was suspended, at a point dependent on this tension. If the tension of the oxygen was diminished by the

1 Arch. Néerland, XXVIII, p. $35^{8}$. 
introduction of hydrogen, the bacterium approached the edge of the drop; if the tension was raised by the introduction of oxygen, it drew away from the edge. If the oxygen is removed, not mechanically, but by the replacement of the air by other gases, it is found that carbon dioxide and sulphuretted hydrogen are poisons for bacteria, while hydrogen seems to have no effect on them. In the fermentation industry it was known long ago that the must could be "aërated" with hydrogen, and that, therefore, not the addition of oxygen, but the removal of carbon dioxide was the important part of the process.

The facts of anaërobiosis are of great importance to technical biology and to pathology. Since, under strictly anaërobiotic conditions, any secondary oxidation of the primary decomposition products is impossible, the latter accumulate without formation of bye-products. In . the technique of fermentation this fact enters into consideration in the so-called "bottom fermentation." In disease, the possibility of extracting physically bound oxygen from the blood plasma is of only secondary importance ; otherwise all individuals who suffer from invasion of the blood by microscopic organisms, would die from carbonic acid poisoning. Formation of carbonic acid, however, may, as a symptom of 
oxidation, contribute to increase the body temperature, i. e., to produce fever (C. Roser). Fever, however; is generally merely the accompaniment of a disease, the more important feature being the formation of primary products by splitting which impart to individual diseases their characteristics. Braatz ${ }^{\mathrm{I}}$ has recently laid stress on the fact that the microbes in suppurating foci are living without atmospheric oxygen. Hueppe ${ }^{2}$ and Scholl $^{3}$ had previously shown that, in cholera, the comma bacilli produce relatively more poison in the absence of air than in its presence, and that the primary anaërobic poisons formed by decomposition are destroyed upon access of oxygen. With anaërobic cholera cultures I succeeded in bringing about typical diarrhœa in animals used for experiment ; previously this had not been accomplished.

Absence of air has a further effect; it enables the microbes to retain for a long time their power of causing fermentation, of producing poison or of bringing about infection. Experiments of Fajans and Hueppe ${ }^{4}$ have shown that cholera cultures retain their virulence for weeks and even months under anaëro-

1 Deutsche med. Wochensch., 1890 , No. 46.

2 Deutsche med. Wochensch., I891, No. 53.

${ }^{8}$ Berl. klin. Wochensch., I890, No. I I, I 2.

* Arch. f. Hyg., XX. 
bic conditions after parallel cultures which have been freely exposed to air have long since lost their potency. Bunzl-Federn has shown the same thing to be true of the very delicate pneumonia germs.

\section{Light and Temperature. Sterilization.}

Adaptation to light is developed in different degrees. While most kinds of bacteria thrive in the absence of light others become as it were dormant, and when these latter are brought again into the presence of light an increase of movement sometimes occurs, as has been observed by Engelmann. One species indeed showed this sensitiveness to light in so striking a manner that it was named by this observer Bacterium photometricum. On the other hand many bacteria are destroyed by direct sunlight: The existence of any special influence of the presence of bacterial pigment upon behavior to light can as a rule not be demonstrated. ${ }^{\mathrm{I}}$. In one species containing chlorophyl, Bacterium chlorinum, Engelmann has demonstrated the giving off of a slight quantity of oxygen. Zopf has found also that cultures of the purple bacteria develop more luxuriantly on that side of an aquarium which is turned towards the light. According to Engelmann,

${ }^{1}$ [See, however, Ewart, Journ. Linn. Soc. Bot., I897, No. 228]. 
however, this purple pigment is like chlorophyl or leaf-green, and must be regarded as a feeblyacting chromophyl which effects possible assimilation of carbon dioxide.

A specially striking adaptation to life in the presence of air is seen in the phenomenon of phosphorescence or luminosity. This phenomenon, which has been investigated by Pflüger, ${ }^{\mathrm{I}}$ Fischer $^{2}$ and Beyerinck, ${ }^{3}$ is to be noticed in decomposing meat and fish and particularly in the phosphorescence of sea-water. As has been shown by Beyerinck and my assistant Weleminsky, it is a vital phenomenon which passes away with death. During life it is dependent upon an abundant supply of oxygen. If the oxygen is replaced by another gas, the luminosity disappears, only to appear again when oxygen is readmitted. Those luminous bacteria which are facultative anaërobes do not show phosphorescence in the anaërobiotic condition, but only upon the entrance of oxygen. The power of luminosity may be lost in cultures.

The remarkable substances known as bacterial pigments, among which we find almost all colors represented, belong to quite diverse

1 Pflüger's Arch. Bd. X., I874, and Bd. XI., I875.

${ }^{2}$ Die Bakterien des Meeres nach den Untersuchungen der Plankton-Expedition, 1894 .

${ }^{3}$ Arch. Néerd. XXIII., I889. 
chemical groups. Some of these pigments arise from the decomposition of proteid bodies and themselves manifest, in part at least, proteid characters. Hoffa and Enoch succeeded in extracting from fluorescing cultures a proteid-like body which in solution gave a fine green fluorescence. Other pigments, as for instance, the familiar red pigment with green fluorescence manufactured by the " miracle germ" are related chemically to the aniline dyes. Hueppe has shown that the magnificent ultramarine blue pigment of blue milk is formed out of proteid substance and also out of ammonia and a substance which is formed both analytically from sugar and synthetically from milk-sugar. Zopf and Overbeck, ${ }^{\mathrm{I}}$ finally, have ascertained that some bacterial pigments belongs to the lipochromes or fatty pigments; according to Bütschli perhaps the bacterio-purpurin of $\mathrm{Beg}$ giatoa also belongs here.

Investigations by Forster ${ }^{2}$ and Fischer ${ }^{3}$ have shown that bacteria exist in the ocean and in the soil which can multiply at $o^{\circ} \mathrm{C}$. They observed, for example, that $M$. phosphorescens grew upon fish and evoked visible luminosity at this temperature in 6-8 days. Zopf observed a species found in surface water

1 Nov. Act d. Kais. Leop.-Carol Akad. LV., I89r, No. 7.

2 Centralbl. f. Bakt. II., I887, XII., r892.

3 Centralbl. f. Bakt. IV., I 888. 
which formed spores even when the water was covered with ice. The majority of soil and water bacteria, however, pass into a kind of cold rigor when the temperature falls to a low point and are no longer able to increase. They grow and multiply only at a temperature above $5^{\circ} \mathrm{C}$, and thrive best at about $20^{\circ} \mathrm{C}$.; the pathogenic germs find their optimum at the blood temperature of about $37^{\circ}$. Globig, ${ }^{\prime}$ however, discovered species in soil which have adapted themselves to the high temperature of the upper layers of the soil, a temperature which, through direct action of the sun's rays, ranges between $I 5^{\circ}$ and $68^{\circ}$; he has also observed others which grow only between $54^{\circ}$ and $64^{\circ}$, at a temperature, that is, at which proteid is usually altered. Van Tieghem observed one species which grows and forms spores even at $74^{\circ}$, and refuses to multiply only when $77^{\circ}$ is reached. Not even those Cyanophycece and diatoms which grow upon the deposits in hot springs are able to endure as high a temperature.

The temperature necessary to produce death varies also extraordinarily. Simple freezing destroys many vegetative cells, but many, on the other hand, withstand the shock. Exposure to rapid alternation of freezing and

${ }^{`}$ Zeitschr. f. Hyg., III., I888. 
thawing is more injurious than a long exposure to a temperature below $0^{\circ}$. Spores endure a still lower temperature than the vegetative forms and, indeed, according to Pictet and Young, they may survive for 20 hours at a temperature of $-\mathrm{I}_{20} \mathrm{O}^{\circ}$. According to recent experiments by Pictet, ${ }^{\mathrm{r}}$ they survive and are able to multiply after being embedded for a short time in frozen oxygen at $-2 \mathrm{I} 3^{\circ}$.

Although, according to Duclaux, the vegetative cells of some species are able to withstand a temperature of from $90^{\circ}-100^{\circ}$, most species enter into a kind of heat rigor at $42^{\circ}-$ $45^{\circ}$ and like other organisms are killed by temperatures of over $55^{\circ}$. The spores of the more resistant species are destroyed by boiling water and steam only after 6 hours exposure, and by steam under pressure, at $\mathrm{IIO}^{\circ}-\mathrm{I}_{2} \mathrm{O}^{\circ}$, after half an hour. (In contrast to this, the digestive and bacterial enzymes when in the moist condition are destroyed by temperatures of above $70^{\circ}$ and of about $-100^{\circ}$. In the dry condition, however, these enzymes withstand the action of high temperatures up to $-\mathrm{I} 7 \mathrm{O}^{\circ}$.) The dense membrane of the endospores and the relatively small amount of water contained in their protoplasm protects them effectively against temperature oscillations.

1 Arch. des sci. phys et nat. XXX., 1893, p. 293. 
Some further effects of temperature are worthy of note. Pasteur discovered that if anthrax bacilli are cultivated between $42^{\circ}$ and $43^{\circ}$, no spore-formation occurs, although at other temperatures it usually takes place when the species finds itself under threatening influences. If the cultures are allowed to remain for some time at this high temperature the virulence, that is to say the power of causing anthrax in animals, decreases. According to Chauveau, Koch, and Gaffky and Löffler, 20 days of exposure at $42^{\circ}$, about six days at $43^{\circ}$, $3-4$ hours at $47^{\circ}$, or $15^{-20}$ minutes at $50^{\circ}-5^{\circ}$, produces a uniform degree of attenuation. Similarly, some endospores are so affected by temperatures of $80^{\circ}-100^{\circ}$ that the vegetative forms to which they give rise have lost their original ability to excite fermentation or disease. Fitz ${ }^{\mathrm{I}}$ established this fact for the bacillus of butyric acid and Arloing and Kitt ${ }^{2}$ later for the bacillus of symptomatic anthrax.

It is possible to make use of this varying behavior to temperature to obtain pure cultures. If in a mixture of different kinds of bacteria or of bacteria with other organisms the endospores of bacteria are present, these are sure to be much more resistant than the other organisms.

1 Ber. der Deutsch. chem. Gesellsch., I882, p. 867 .

2 Centralbl. f. Bakt., III., I 888. 
If such a mixture is heated these other organisms and the vegetative forms of the bacteria are the first to be killed; by this means such spores as have retained their vitality can be separated from other germs. In this way Roberts ${ }^{\mathrm{I}}$ secured for the first time pure cultures of the so-called hay bacillus by boiling hay infusion for an hour. We do not, to be sure, always obtain in this way a single species in "pure culture," but simply a culture of all those germs which happen to be present and possess spores of approximately equal resistance. So it happens that under the names "hay bacillus" and "potato bacillus" are commoniy included not a single species but a mixture which, by the aid of other methods, may be resolved into several true species.

\section{Steritization.}

By selecting temperatures so low that germs. cannot develop, putrescible substances can be preserved from spoiling. This is what is accomplished by the use of ice, by refrigerating chambers for the cold storage of meat, and by the chilling of milk. For effectual conservation it is better, however, to destroy the germs utterly. This process of making a substance free from all germs is generally called ${ }^{1}$ Cf. Zopf. Die Spaltpilze, I885, p. 74. 
sterilization, or, in the particular case of wound infection, antisepsis. A term commonly used in connection with infectious diseases or epidemics is disinfection, meaning thereby the destruction of infectious matter. A temperature of over $100^{\circ} \mathrm{C}$ gives the surest results. Pure, air-free steam at a temperature of about $\mathrm{I}_{2 \mathrm{O}^{\circ}}$ or at a pressure of $\mathrm{I} \frac{1}{2}$ atmospheres is ordinarily employed, since no bacterial spores are able to endure its action for more than half an hour. Streaming steam, free from air but not under pressure and at a temperature of about $\mathrm{IOO}^{\circ}$, can also be used, but to be effective it demands a longer time. Both these principles have been embodied in the construction of large, stationary pieces of apparatus and in small transportable devices. By means of these the whole technique of disinfection has been remodeled and such processes as the sterilizing of milk for children have been made possible on a large scale.

For other purposes we are able to reach the same end-only somewhat less convenientlyby long boiling, either direct or in a waterbath. It is often necessary, however, as our housewives know from their experience in the boiling down of fruits, to repeat the heating operation several times on different days. This modification is called intermittent or discon- 
tinuous sterilization. The explanation of this process was first given by Tyndall. Many germs resist the first heating, and subsequently develop in the favorable nutrient solution; but the germs when in this immature condition are less resistant and hence are surely destroyed by a second application of heat. This method is effective even when carried out at temperatures of about $70^{\circ}-75^{\circ}$. Such temperatures are below the coagulation point of proteids, and hence blood and other proteid-containing fluids such as milk and beer can be made germ-free by discontinuous heating, although their proteids would be precipitated by the temperature of boiling water. The use of temperatures from $65^{\circ}-68^{\circ}$ in such cases is called the method of pasteurization.

The resistance of bacteria to drying is developed in different degrees, and depends in general upon the character of the species, the extent of zoöglœa formation and upon the presence of spores. Cholera bacteria vary in their resistance to drying and often exhibit differences of from a few hours to upwards of eight months. Anthrax spores and other endospores have been found to be still capable of development after remaining in a dry condition for ten years. The toxicity of cultures slowly desiccated in the air decreases more or less rapidly, as 
Pasteur first demonstrated for the bacteria of chicken cholera, and as has been subsequently ascertained to be the case with the pneumonia and cholera germs.

F. Cohn discovered that if dry hay or cotton waste be moistened its temperature rises and a sort of fermentation sets in which rapidly raises the temperature of the mass to $67.2^{\circ}$. This fermentation is caused by different bacteria, but especially by a species of micrococcus and by the hay bacillus. In Augsburg high temperatures produced in this way are used in the heating of green-houses. If such masses of organic substance which dampening has caused to ferment come in contact with any dry, dust-like material, this latter may burst into flame. Some cases of "spontaneous combustion" may possibly be due, therefore, to bacterial growth.

As regards the action of electricity on bacteria, special investigations by $\mathrm{Krïger}^{\mathrm{I}}$ have supplemented the earlier works in which stress was laid exclusively upon electrolytic effects. According to Krïger the constant current, when the chemical effect of the ions is eliminated as completely as possible by means of unpolarizable electrodes, does not kill bacteria but does completely inhibit their growth. If the

${ }^{1}$ Zeitschr. f. klin. Me丸., XXII., p. rgr. 
THE VITAL PHENOMENA OF BACTERIA. 71

coöperation of the ions be brought into play, the constant current, when of sufficient strength, intensity and duration, is able to destroy both bacteria and their spores. The electric current acts upon toxic bacterial cultures in such a way as to remove their toxicity, and cultures treated in this way, with their toxic power destroyed, are able to confer immunity.

Disinfection. Effect of Poisons.

The behavior of bacteria towards chemical agents has been much investigated, especially upon practical grounds, in order to obtain disinfectants against disease germs, and antiseptics against the germs of putrefaction. The distinguished military physician and epidemiologist Pringle carried out experiments in the last century upon the action of disinfecting substances on infectious material. Unfortu-. nately a period of crude empiricism followed, in which men allowed themselves to be guided by the sense of smell and to conclude upon the cessation of a nauseous stench that they had destroyed the cause of the disease. Under the sway of this idea sulphate of iron obtained particular favor as a disinfectant, and among army surgeons the fresh whitewashing of rooms also achieved fame as a method of disinfection. 
The first to establish a new era were Semmelweiss, who may be regarded as the originator of the aseptic method of treating wounds and who recommended the use of chlorine water for cleansing the hands, and the French apothecary Lemaire, who recognized the fact that disinfectants killed microbes but did not alter unorganized ferments. Lemaire found that carbolic acid was the best agent for disinfection, and this substance was later brought into general use by Lister for the antiseptic bandaging of wounds. Jalan de la Croix and Koch afterwards brought these empirical methods to the highest point of efficiency ; Koch clearly distinguished between the action of chemical substances upon vegetative stages and upon resting stages, and between the death of bacteria and simple inhibition of their growth. Both investigators ascertained that the poisonons substance corrosive sublimate was the most effective of all agents, and that chlorine was more serviceable than carbolic acid. According to Koch, anthrax spores were prevented from germination by the presence in the nutrient medium of corrosive sublimate, I : 300,000; of hydrochloric acid, I : I 700; of salicylic acid, I : I500; of potash soap, I : IOOO; carbolic acid, I : 850 ; quinine, I : 625 ; alcohol, I : I2.5. Only a few substances brought about 
death of the spores inside of 24 hours. A .2\% solution of corrosive sublimate caused death of the spores inside one hour, as was also the case with a $.2 \%$ solution of fresh chlorine water, while other agents required many days ; a $5 \%$ carbolic acid solution for instance needed more than forty days. On the other hand, many substances caused death of the vegetative forms in the course of a few minutes.

A better understanding of these processes was arrived at when it became recognized that mechanical purification must precede disinfection. Acids and alkalies again came into repute, and it was found that strongly concentrated preparations of the alkalies, of caustic soda, of quick-lime, and of milk of lime dissolved in water $\left(\mathrm{CaO}+\mathrm{H}_{2} \mathrm{O}=\mathrm{Ca}(\mathrm{OH})_{2}\right)$ were good disinfectants, and indeed that common soda itself killed germs; that a direct influence was exerted upon the proteid of the bacterial cell was consequently inferred. For the same reason the acids act as disinfecting agents. Bacteria are more susceptible to the action of the mineral acids, like sulphuric, nitric and hydrochloric acids, than to that of the vegetable acids like tartaric and citric, and least susceptible toward those which some bacteria themselves produce, such as acetic, butyric and lactic. When the latter are formed in the 
course of bacterial growth, development of the germs ceases when a certain definite proportion of the acid in solution is reached. This proportion has been accurately determined by Hueppe in the case of lactic acid, and a similar inhibiting point has been shown to exist in the case of the alcohol produced by yeast. If the lactic acid is neutralized by the addition of carbonate of lime, fermentation starts up again. From thesefacts was deduced a principle of immediate practical importance, viz., that quick-lime and milk of lime are disinfecting agents only so long as sufficient calcium hydroxide $\left(\mathrm{Ca}(\mathrm{OH})_{2}\right)$, is present. If this compound is converted into carbonate of lime by the carbon dioxide of the atmosphere or in solution, then the substance is a disinfecting agent no longer, but, on the contrary, a favorable medium for bacterial vegetation since a feebly alkaline reaction of the nutrient medium generally favors bacterial growth. In fruit preserving, again, it is of interest to know that the vegetable acids that are present check bacterial growth but permit the vegetation of moulds.

The hydrochloric acid contained in the gastric juice constitutes an important means of defence against bacterial invasion. This sort of safeguard is not, however, developed to an equal extent in different individuals and 
species of animals. In conditions due to fasting, to catarrh of the stomach and to overloading of the stomach, the amount of hydrochloric acid present does not suffice for protection, so that, to take an example, conditions resulting either from hunger or from over-eating, as well as from diseases of the stomach, may facilitate cholera infection.

Corrosive sublimate is less effective as a germicide in alkaline fluids containing much albuminous substance than in watery solution. In such fluids precipitates of albuminate of mercury are formed which are at first insoluble so that a part of the mercuric salt does not really exert any action. If these albuminates of mercury are dissolved in an excess of blood or bloodserum, they become very effective, and Lister has even recommended them for use in the bandaging of wounds. In alkaline solutions such as blood, blood-serum, pus, tissue-fluids, etc., the soluble compounds of mercury are converted into oxides or hydroxides. The soluble compounds can of course remain in solution only when there are present sufficient quantities of certain bodies which render solution possible. Bodies of this sort are especially the alkaline chlorides and iodides and, above all, sodium chloride and ammonium chloride. A very simple way of preventing precipitation of the 
mercury, then, is to add a suitable quantity of common salt to the corrosive sublimate. Those compounds of mercury which, like the cyanides, are not precipitated with alkalies because they at once form double salts, require no addition of salt. These facts were recognized several decades ago and made use of in medicine, but had altogether fallen into oblivion until Liebreich and later Behring again brought them to light. The double salt of mercuric chloride and sodium chloride is precipitated by the earthy alkalies, although not by the alkaline carbonates, so that the solution should be prepared with distilled water or with soft water. Taking into consideration the matter of solubility, gold and silver salts such as potassium auri-cyanide and silver nitrate or.1unar caustic are very powerful antiseptics.

Pure carbolic acid or phenol $\left(\mathrm{C}_{6} \mathrm{H}_{5} \mathrm{OH}\right)$ is soluble in water, but the crude carbolic acid dissolves only with difficulty. For this reason various means have been devised for making the commercial acid soluble in water. Hueppe found that if a solution was prepared with sulphuric acid the phenol sulfonic acids which arise through the replacement by $\mathrm{HSO}_{3}$ of an atom of hydrogen in the phenol and which are readily soluble in water act very energetically upon bacteria. Under the name of aseptol they have 
come into practical use as disinfectants. Incidentally the observation was made (which is interesting as regards hypotheses of molecular constitution), that ortho-phenol sulfonic acid acts very strongly upon anthrax spores, but that the para-compound, which is produced by heating the ortho-compound, does not. The difference in the action of these two compounds upon the vegetative cells is not so great. Laplace prepared mixtures of crude carbolic acid and sulphuric acid which were very active, indeed more active when they were made in the cold than when made at a higher temperature. This latter fact might favor the view that in the cold the real ortho-sulfonic acids are formed, while at the higher temperature only the less active para-sulfonic acids appear, but might also, as C. Fränkel thinks, be explained on the supposition that in the cold we obtain only mixtures with sulphuric acids; in the warmth real sulfonic acids. Mixtures are indeed, as Rotter first showed, often more effective than the individual components, but Biel has found that as a matter of fact the sulfonic acids of cresol are formed in the cold. It is an important fact, however, that in crude carbolic acid, cresol $\left(\mathrm{C}_{6} \mathrm{H}_{4} \mathrm{CH}_{3} \mathrm{OH}\right)$, as well as phenol $\left(\mathrm{C}_{6} \mathrm{H}_{5} \mathrm{OH}\right)$, is present in large quantities. According to C. Fränkel, the former has a greater 
disinfecting power than phenol. The cresols are, however, so difficultly soluble in water that their action is not sufficiently powerful to destroy all bacteria, especially the spores.

Since solution by means of mineral acids affords strongly corrosive and destructive compounds, an attempt has been made to convert the cresols of the crude carbolic acid, which are almost useless for purposes of disinfection because of their slight solubility, into a form soluble in water, in order to utilize thereby their disinfecting power. Phenol and cresol are easily soluble in soap solutions, hydrocarbons difficultly so. If we start with a coaltar oil which contains much hydrocarbon and little phenol, and mix it with soap and dilute with water, an emulsion is obtained; this is the so-called creolin. If on the other hand we take first a coal-tar oil which contains little hydrocarbon and more phenol and mix this with soap, and dilute with water, we obtain a solution; examples of this are the disinfectants sapocarbol and lysol. Mixtures of crude carbolic acid and soap prepared in this way turn to good account the disinfecting power of cresol. If cresol, which is by itself barely soluble in water, be mixed with the difficultly soluble salts of the ortho-oxy-carbo- or ortho-oxysulfonic acids, the mixture is soluble in water, 
both of the difficultly soluble compounds being rendered easily soluble. Cresol and sodium salicylicate taken separately are likewise difficultly soluble in water, but are readily soluble when mixed. Sodium cresotinate is for this purpose even better than sodium salicylicate and, when used in this way, the resulting substances were designated by me as solveole; they are neutral and not corrosive. Sodium cresol is more easily soluble than cresol but somewhat less powerful, just as sodium phenol is less powerful than phenol. A large quantity of cresol, however, dissolves in sodium cresol, so that we can obtain watery alkaline solutions of cresol in sodium cresol with any required percentage content of cresol. I have called this preparation solutol. The efficiency of all these preparations depends partly upon their cresol content which, on account of their solubility in water, may be very great (cresol itself is soluble to the extent of only about .5-I p.c.in water), and partly upon the solvent. The absolutely neutral solveol is therefore a better antiseptic for wounds than the corrosive carbolic acid, and contains a larger quantity of cresol than a solution in water. Lysol emulsifies fat by its soaps, while the alkaline solutol penetrates crevices, saponifies fats, dissolves proteid bodies, and therefore unites the 
disinfecting power of cresol with the purifying power of the alkalies.

Salicylic acid $\left(\mathrm{C}_{6} \mathrm{H}_{4} \mathrm{COOH} . \mathrm{OH}\right)$, is also a powerful disinfectant. The structural formulæ of the substances just discussed, phenol, cresol, salicylic acid and the phenol sulfonic acids, prompt the conjecture that disinfective power stands in relation to the complexity and reactivity of the atom groups in the molecule. For we may anticipate that these reactive atom groups can interlock with and upset the atom groups of the unstable proteid molecule more easily than can less mobile atom groups. It might be fairly expected that with the entrance into chemical bodies of such atom groups as exalt the reaciive character of these bodies, a poisonous effect would become manifest. Phenol or mono-oxy-benzol $\left(\mathrm{C}_{6} \mathrm{H}_{5} \mathrm{OH}\right)$, therefore, should be less poisonous than dioxy-benzol $\left(\mathrm{C}_{6} \mathrm{H}_{4}(\mathrm{OH})_{2}\right)$, which in its turn should be less so than tri-oxy-benzol $\left(\mathrm{C}_{6} \mathrm{H}_{3}\right.$ $\left.(\mathrm{OH})_{3}\right)$. Now the ortho-di-oxy-benzol or pyrocatechin, the analogous meta-compound or resorcin, and the paracompound or hydrochinon, are, indeed, to be regarded as poisonous, but not as more poisonous than phenol. The same thing holds true of the tri-oxy-benzols, among which pyrogallol, oxy-hydrochinon and phloroglucin may be looked upon as less poisonous 
than phenol. Phenol is, however, a very reactive body, so that the exception is only apparent.

Regarding isomeric bodies the chemically more reactive might be supposed to be the more poisonous. For example, the isonitriles or isocyanides or carbylamine whose base is a hypothetical isocyanic acid or isoprussic acid

of the formula CN.H (more accurately $\mathrm{C} \equiv \mathrm{N}-\mathrm{H}$, III

or, according to others, $\mathrm{C}=\mathrm{N}-\mathrm{H}$ ) ought to be more poisonous because more reactive than the nitriles or cyanides whose base is the prussic acid of the formula H.CN (more accuIII

rately $\mathrm{N} \equiv \mathrm{C}-\mathrm{H})$. The mustard oils which are derived from the hypothetical iso-st1phocyanic acid (S. CN. H) are not poisonous, the sulpho-cyanates which are derived from the sulpho-cyanic acid (S. H. CN) are poisonous. One of the most potent poisons known, prussic acid $(\mathrm{H}$. CN), or formic acid nitrile, belongs to the nitriles. It is, to be sure, very reactive, so that the foregoing exceptions are, perhaps, only apparent. These examples have been chosen in order to show that we are but just entering upon a rigorous scientific conception of the nature of these questions, and are still at the beginning of the development of laws. 
Perhaps the exceptions to the rule above noted may be explained on the assumption that the molecular structure of living cells has led to great differences in the structure of the unstable proteid of the living protoplast, and that chlorophyl-containing and chlorophyl-free cells, as well as the various cells of the different organs and tissues in animals and plants, present, through adaptations, variations with which the atom groupings of chemicals have to reckon.

It is true in general that disinfectants whose action upon protoplasm is simply that of a poison do even more damage to the cells of man and other animals than to the bacterial cell. In spite of this fact the internal use of an antiseptic substance is conceivable. Behring has found in the case of. a number of chemical substances that a sub-cutaneous inoculation of approximately one-sixth part -reckoned upon the weight of the test animal-of that quantity of a given substance which, in blood-serum, arrests the development of the anthrax bacillus certainly kills the animal and that, consequently, inhibition of bacterial development and poisonuus action upon man and the lower animals go hand in hand. But apart from the fact that we cannot yet make a universal application of the above rule, the experiments made up to this time indi- 
cate that the property of inhibition and that of disinfection do not always run parallel, just as might be expected from the fact that direct corrosive effects differ from phenomena that take place in blood and tissue juices. Poisonousness is, therefore, only relative. From this point of view the cresols are to be regarded as from two to four times as strongly disinfectant towards some bacteria as carbolic acid, or from two to four times less poisonous than carbolic acid. That is to say, from one-half to onefourth part of cresol possesses as great disinfecting power as one part of phenol. Since both bodies are equally poisonous, it is best to use the smaller amount of cresol and thus to minimize the danger from poisoning. Again, the very powerful disinfectant iodine tri-chloride is, according to Behring, relatively harmless, since at the beginning of the disinfecting process sodium iodide and sodium chloride are formed. As early as I886 it was discovered also that the ortho-phenol-sulfonic acids have just as strong disinfecting power as the phenols ; they corrode less and are not so poisonous.

These effects are in the line of specific disinfection, that is the disinfectant acts more injuriously upon the bacteria than upon the cells of the human body. It is perhaps to be remarked as an advance in the same direction 
that we successfully administer quinine for malaria, mercury preparations for syphilis, and salicylic acid for rheumatism. The search after similar specifics is certainly not to be regarded as hopeless when it is remembered that quinine is a stronger poison for the lower animals or for the algæ than strychnine or morphine, while with the higher animals the reverse is the case. According to Donath, chinolin is harmless for yeasts, but is a poison for the bacteria of putrefaction.

We shall see that in a way to be considered later the aldehyde group $(\mathrm{COH})$ and the amido group $\left(\mathrm{NH}_{2}\right)$ are of particularly great importance in the construction of organic substance, especially proteid, and play a prominent rôle in the activity of the protoplasmic proteids of all cells. On the strength of the foregoing fact, Oscar Löw predicted and then proved by many experiments, since confirmed by other investigators, that all substances which attack these atom groups are poisons, since they destroy the stability of the active proteid molecule and so arrest life. Such substances, which are proved to be poisons for protoplasm in general, must be also poisons for bacteria, and hence suitable for purposes of antisepsis, disinfeclion or sterilization. Examples of such bodies which, even in great 
THE VITAL PHENOMENA OF BACTERIA. 85

dilution, attack aldehyde groups and whose poisonous action upon protoplasts and bacteria has been proved by Löw, Marpmann, and $H$. Buchner, are prussic or hydrocyanic acid $(\mathrm{HCN})$, diamid $\left(\mathrm{N}_{2} \mathrm{H}_{4}\right)$, hydroxylamine $\left(\mathrm{NH}_{2}\right.$ $\mathrm{OH})$, phenyl-hydrazine $\left(\mathrm{C}_{6} \mathrm{H}_{5}\right)$ NH. $\left.\mathrm{NH}_{2}\right)$ and sulphuretted hydrogen $\left(\mathrm{H}_{2} \mathrm{~S}\right)$. Similar bodies, which even in great dilution attack amido groups, and whose poisonous, or disinfecting qualities, have been proved, are, according to Löw, Buchner, Kitasato and Weyl, nitrous acid $\left(\mathrm{N}_{2} \mathrm{O}_{3}\right)$, free cyanogen or dicyanogen $\left(\mathrm{C}_{2} \mathrm{~N}_{2}\right)$, formaldehyde $(\mathrm{H}$. COH $)$, acetaldehyde $\left(\mathrm{CH}_{3} \mathrm{COH}\right)$ and benzaldehyde $\left(\mathrm{C}_{6} \mathrm{H}_{5} \cdot \mathrm{COH}\right)$.

Some poisons, as for example alcohol, may be harmless in small quantities since they are easily oxidized in the presence of oxygen, and others, such as salicylic acid, indol and phenol, may condense or unite with other bodies into non-poisonous or slightly poisonous products.

The connection which the reactivity of atom groups has with their toxic properties is shown also by the fact that bodies which, in a given degree of concentration, exert no injurious effect upon bacteria at the room temperature (about $15^{\circ}$ ), do destroy bacteria when the temperature is raised to $37^{\circ}$, and still more certainly if it be raised to $50^{\circ}-60^{\circ}$. (Henle, Behring, Heiden and Hammer have ascer- 
tained this fact for anthrax spores.) The high temperature increases the amplitude of vibration of the movable atom groups within the proteid molecule until the molecule, at the temperature that causes rigor and death, is rent asunder and passes over from the condition of true, active, unstable proteid into the state of rigid, inactive, dead proteid. That this conception is in reality correct follows from the fact that Scholl was able by treatment with potash to restore to serum albumin a measure of the activity which had been arrested by heat.

In other cases the active proteid appears like an anhydride of dead proteid; at all events, on hydration it passes over into an inactive condition. In still other cases the active proteid seems like a polymerization product of dead, inactive proteid. In every instance, however, the real, living, active proteid is an extraordinarily complex structure as contrasted with the inactive, dead proteid with which alone, until a recent date, the chemist has worked. Such active proteid is endowed, through the reactivity of the atom groups in its molecule, with numerous possibilities of movement. Through communication of the molecular movements which result from such reactivity, active proteid may on its side affect other reactive chemi- 
cal bodies and other reactive proteids, that is, it may act as a poison or disinfectant.

The action of the so-called unorganized ferments or enzymes has been thought for a long time to be due to such a property. Some of these enzymes break up proteids, fats and carbohydrates by hydrolytic splitting; in this way albumoses and peptones are formed out of albuminates, and fatty acids and glycerine out of fats. For example :

$$
\left(\mathrm{C}_{18} \mathrm{H}_{35} \mathrm{O}\right)_{3} \mathrm{C}_{3} \mathrm{H}_{5} \mathrm{O}_{3}+{ }_{3} \mathrm{H}_{2} \mathrm{O}={ }_{3} \mathrm{C}_{18} \mathrm{H}_{36} \mathrm{O}_{2}+\mathrm{C}_{3} \mathrm{H}_{8} \mathrm{O}_{3}
$$

tristearin, water, stearic acid, glycerine. and :

$$
\begin{aligned}
& \mathrm{C}_{44} \mathrm{H}_{90} \mathrm{NPO}_{9}+3 \mathrm{H}_{2} \mathrm{O}={ }_{2} \mathrm{C}_{18} \mathrm{H}_{36} \mathrm{O}_{2}+ \\
& \text { lecithin, water, stearic acid, } \\
& \mathrm{C}_{3} \mathrm{H}_{9} \mathrm{PO}_{6}+\mathrm{C}_{5} \mathrm{H}_{15} \mathrm{NO}_{2} \\
& \text { cholin, }
\end{aligned}
$$

Examples of the hydrolysis of carbohydrates have been already tabulated on p. 34. Other enzymes, as for example rennet and an enzyme found in the blood, bring about coagulation of albumin. Similar effects are wrought by bacteria, and enzymes can be isolated from the cells and the same action brought about independently of the living bacteria themselves. Hueppe and Fermi ${ }^{\mathrm{I}}$ have demonstrated the existence of bacterial enzymes capable respectively of fermenting milk-sugar, of bringing about hydration of starch, of co1 Centralbl. f. Bakt. VII., I889, p. 449. 
agulating casein and of dissolving proteid. Koch has made use of the ability of many bacteria to peptonize, dissolve and liquefy gelatin as a basis for the separation of bacteria into groups.

Yet more remarkable is the fact that active blood-serum and active tissue juices, fresh milk, etc., possess the ability to kill bacteria and sometimes display extraordinary activity in this direction. H. Buchner was the first to recognize and demonstrate this; he was able by heating these substances to $60^{\circ}-70^{\circ}$ to annul their effect. Behring next recognized that active blood-serum can nullify the effect of bacterial poisons. The addition of carbolic acid, thymol, cresol, toluene, or chloroform, partially preserves the activity of these body-fluids as it does that of enzymes. Certain of these active proteid bodies act precisely like enzymes, so that between the newly discovered group and the old no sharp line of demarcation can be drawn. When carefully dried, both groups of substances withstand high temperatures, while, in a moist condition, their power is destroyed by heating. Many of the "specific" bacterial poisons belong to this group of enzymes and active proteid bodies.

Behring was the first to recognize that one substance ordinarily alleged to be an effective 
antiseptic, the villainously smelling iodoform, is in reality effective as an antiseptic only when iodine is split off-which is somewhat unusual -and that, as a rule, its action is simply to annul the effect of the bacterial poisons. In this connection it may be said that I have found that the bismuth salt of tribromphenol, which has little odor, and in combination none at all, and which is a powerful disinfectant, is able to destroy bacterial poisons far better than iodoform.

Of great interest is the discovery by Naegeli ${ }^{\text {I }}$ of the fact that a mere trace of metallic copper proves fatal to algal protoplasm ; such an action is called by him "oligodynamic." Similarly, Miller and Behring have found that metallic gold and copper can arrest the development of bacteria, although no perceptible trace of the metals goes into solution. Leaving out of consideration for the moment such phenomena, which are as yet but little understood, as well as the fact that certain chemical bodies, even when in extreme dilution, attack atom groups essential to the vitality of living proteid, a generally valid conclusion for the effect of chemicals upon protoplasts may still be drawn. Arndt, Schultz, and Hueppe have, independently of one another, formu1 Cf. Biol. Centralbl. XIV., p. I29. 
lated a biological law to the effect that every chemical substance which, in a given concentration, destroys the life of protoplasm, and in smaller quantity checks development, acts when in still smaller proportions (on the other side of an indifferent point) as a stimulus and increases the vital manifestations.

In agreement with the above statement is the fact ascertained by Chamberland, Roux and Phisalix, that it is possible, by adding a certain quantity of carbolic acid or chromic acid to anthrax cultures, to destroy the sporeforming property of the germs, and to diminish their virulence or attenuate them to a definite extent. Smirnow and Flügge have shown that, in general, attenuated microbes are less resistant to chemical influences than virulent cultures. For example, the virulent anthrax bacillus grows well with the addition of four drops of 2 p.c. hydrochloric acid to the nutrient gelatin, but the growth of a slightly attenuated bacillus in presence of the same quantity of acid is much retarded and a highly attenuated germ does not grow at all. Hammer has found that when pathogenic bacteria are attenuated the virulence of the spores is impaired before their power of development has suffered, and Behring has even obtained growth after the spores have lost all power to kill. 


\section{Chemistry of the Nutrient Substratum.}

Up to a few years ago it was considered an unimpeachable tenet of biology that only the plants possessing leaf-green or chlorophyl are able to decompose carbon dioxide, by setting free the oxygen and utilizing the carbon in the construction of cell substance, starch or sugar. The energy for this synthesis is afforded by the sun's rays. Plants containing no chlorophyl and all animals, it was supposed, lacked the power to assimilate carbon dioxide. The assimilation of carbon dioxide by green plants takes place through the synthesis of formaldehyde out of water and carbon dioxide; sugar arises out of the formaldehyde by polymerization; multiplication of the aldehyde formula by six gives the empirical formula of grapesugar:

\begin{tabular}{|c|c|}
\hline $\begin{array}{c}\text { I. } \mathrm{H}_{2} \mathrm{CO}_{3} \\
\text { carbonic acid, }\end{array}$ & $=\underset{\text { formaldehyde }}{\mathrm{CH}_{2} \mathrm{O}+}$ \\
\hline formaldehyde, & $\begin{array}{l}\mathrm{C}_{6} \mathrm{H}_{12} \mathrm{O}_{6} \\
\text { grape-sugar. }\end{array}$ \\
\hline
\end{tabular}

Even before E. Fischer's remarkable achievements in the synthesis of the carbohydrates, Löw, starting with formaldehyde, had succeeded in building up the first sugar, called formose (acrose), out of its elements. Organic chemistry has now accomplished the synthesis of polysaccharides like maltose and dextrine 
out of grape-sugar, the construction that is, of complicated compounds of sugar with other bodies. For examples of the decomposition of maltose, dextrine or starch, I may refer to p. 52 . The following illustration of the decomposition of glucosides may be permitted :

$\mathrm{C}_{20} \mathrm{H}_{27} \mathrm{NO}_{11}+2 \mathrm{H}_{2} \mathrm{O}={ }_{2} \mathrm{C}_{6} \mathrm{H}_{12} \mathrm{O}_{6}+\mathrm{C}_{6} \mathrm{H}_{5} \cdot \mathrm{COH}+\mathrm{HCN}$ amygdalin, water, grape-sugar, benzaldehyde, prussic acid. $\mathrm{C}_{27} \mathrm{H}_{22} \mathrm{O}_{17}+{ }_{4} \mathrm{H}_{2} \mathrm{O}=\mathrm{C}_{6} \mathrm{H}_{12} \mathrm{O}_{6}+{ }_{3} \mathrm{C}_{7} \mathrm{H}_{6} \mathrm{O}_{5}$ tannic acid, water, grape-sugar, gallic acid.

According to, recent synthetic work, the polysaccharides, such as starch, dextrine, canesugar, malt-sugar or maltose and milk-sugar are to be regarded as glucosides of the simple sugars. In this connection we may note the interesting fact that new carbohydrates may be produced from other carbohydrates by the action of prussic acid, and that prussic acid itself may arise also as a decomposition product. We know that prussic acid ( $\mathrm{HCN})$, one of the most potent of the nitrogenous poisons, under the influence of polymerization can become non-poisonous and even available for the construction of organic substance, as Pfluger was the first to demonstrate : for example, adenin, a normal element of the cells of both higher and lower organisms, possesses, according to its discoverer Kossel, the formula $\mathrm{H}_{5} \mathrm{C}_{5} \mathrm{~N}_{5}$, or five molecules of prussic acid $(5 \mathrm{HCN})$. According 
to its constitution it is amidohypoxanthin $\mathrm{C}_{5} \mathrm{H}_{4} \mathrm{NHN}_{4}$ and on fusion with potassium, forms potassium cyanide $(\mathrm{KCN})$.

Under the action of strong hydrochloric acid the glucoses also form polysaccharides, such as isomaltose and dextrine. Through the combination of synthetic bodies of this character with ammonia $\left(\mathrm{NH}_{3}\right)$ or with the amido group $\left(\mathrm{NH}_{2}\right)$ derived from it, proteid arises. According to Oscar Löw, the following formulæ in a manner express the conceptions which may be formed regarding the construction of proteid through polymerization, synthesis, anhydrideformation, reduction and condensation of the molecules thus originated. Only the more important intermediate stages are considered.

I. $\mathrm{H}_{2} \mathrm{CO}_{3}=\mathrm{CH}_{2} \mathrm{O}+\mathrm{O}_{2}$ (or any other mode of formcarbonic acid, formaldehyde, oxygen. ation of formaldehyde).

II. ${ }_{4} \mathrm{CH}_{2} \mathrm{O}+\mathrm{NH}_{3}=\mathrm{C}_{4} \mathrm{H}_{7} \mathrm{NO}_{2}+{ }_{2} \mathrm{H}_{2} \mathrm{O}$ formaldehyde, ammonia, aldehyde of aspartic acid, water.

(i e. an amido-acid.)

III. $3\left(\mathrm{C}_{4} \mathrm{H}_{7} \mathrm{NO}_{2}\right)=\mathrm{C}_{12} \mathrm{H}_{17} \mathrm{~N}_{3} \mathrm{O}_{4}+2 \mathrm{H}_{2} \mathrm{O}$

IV. $6\left(\mathrm{C}_{12} \mathrm{H}_{17} \mathrm{~N}_{3} \mathrm{O}_{4}\right)+6 \mathrm{H}_{2}+\mathrm{H}_{2} \mathrm{~S}=\mathrm{C}_{72} \mathrm{H}_{112} \mathrm{~N}_{18} \mathrm{SO}_{22}+2 \mathrm{H}_{2} \mathrm{O}$ simplest expression for proteid.

That it is possible to pass from inert, lifeless proteid to the active, living proteid, and that Scholl succeeded in one case in making again active a proteid which had been rendered passive through heat are facts already mentioned. 
Recently Lilienfeld and Wolkowicz, with amido acetic ethyl ester as a basis, have obtained a kind of gelatin peptone and, by combination of this synthetic body with the ethyl ester of leucin and tyrosin, have built up a sulphurfree body similar to proteid. Ammonia, that is to say the amido group $\mathrm{NH}_{2}$, and formaldehyde are looked upon as the first members of the series. We are now able, in order to make clear the more intimate arrangement of the atoms composing formaldehyde, to write its formula $\mathrm{CH} . \mathrm{OH}$ or to use the arrangement $\mathrm{H}$. COH to bring out the aldehyde group.

If we possess ammonia for a source of nitrogen we may expect that all chemical bodies which contain ready-made formaldehyde, or are able to form it by simple rearrangement of the atoms can serve also as material for the synthesis of carbohydrates or of the nitrogen-free group of proteids. Experience has confirmed this expectation to the fullest extent, and especially is this true of those bodies that contain the groups $\mathrm{CH} . \mathrm{OH}$ or $\mathrm{H} . \mathrm{COH}$ (that is, $\mathrm{COH}$ ) or that form it by loss of hydrogen $\left(\mathrm{CH}_{2} \mathrm{OH}-\mathrm{H}=\mathrm{CHOH}\right)$.

I may call attention, however, to the fact that formaldehyde itself, as already mentioned, is a protoplasmic poison, since in the free condition even in great dilution it attacks amido 
groups, but that in combination, as for instance with sodium sulphite $\left(\mathrm{Na}_{2} \mathrm{SO}_{3}\right)$, it loses its poisonous' quality and can serve as a food for protoplasm. Pasteur long ago established the same fact in the case of tartaric acid; the rule holds good likewise for succinic and malic acids. Neelsen and I found the same thing true of lactic acid, and I was eventually able to make quite a simple solution with ammonium lactate, in which the bacteria of "blue milk" form synthetically the same pigment which in milk they form analytically. (According to Uschinsky, cholera and diphtheria germs also form synthetic poisons in a similar solution.) In like fashion certain sugars may afford fit material for this kind of synthesis.

If we place the constitutional formula side by side with the empirical, a difference becomes at once manifest between such compounds as tartaric acid or malic acid which contain $\mathrm{CHOH}$ and succinic acid, and also between lactic acid and propionic acid :

Tartaric acid $\mathrm{C}_{4} \mathrm{H}_{6} \mathrm{O}_{6}=\mathrm{CHOH} . \mathrm{COOH}-\mathrm{CHOH} . \mathrm{COOH}$.

Malic acid $\quad \mathrm{C}_{4} \mathrm{H}_{6} \mathrm{O}_{5}=\mathrm{CHOH} . \mathrm{COOH}-\mathrm{CH}_{2}$. COOH.

Succinic acid $\mathrm{C}_{4} \mathrm{H}_{6} \mathrm{O}_{4}=\mathrm{COOH} . \mathrm{CH}_{2}-\mathrm{CH}_{2} . \mathrm{COOH}$.

Lactic acid $\quad \mathrm{C}_{3} \mathrm{H}_{6} \mathrm{O}_{3}=\mathrm{CH}_{3}-\mathrm{CHOH} . \mathrm{COOH}$.

Propionic acid $\mathrm{C}_{3} \mathrm{H}_{6} \mathrm{O}_{2}=\mathrm{CH}_{3}-\mathrm{CH}_{2}-\mathrm{COOH}$.

Whereas tartaric, malic and lactic acids contain the group $\mathrm{CHOH}$ and can readily yield formaldehyde or the aldehyde group 
$\mathrm{COH}$, succinic acid and propionic acid are able to yield this group only by oxidation, i. e., $\mathrm{CH}_{2}+\mathrm{O}=\mathrm{CHOH}$. The former bodies are, as a matter of fact, altogether better food-substances for bacteria than the latter, and, furthermore, the former have nutritious value under all conditions, and especially in anaërobiosis, while the latter can be used for food only in the presence of oxygen. As an example of the utilization of such substances, both in conditions of anaërobiosis and aërobiosis, tartaric acid may be instanced (cf. Löw).

In the absence of oxygen :

$$
\mathrm{C}_{4} \mathrm{H}_{6} \mathrm{O}_{6}=2 \mathrm{CH}_{2} \mathrm{O}+\mathrm{H}_{2}+{ }_{2} \mathrm{CO}_{2}
$$

tartaric acid, formaldehyde, hydrogen, carbon dioxide.

In the presence of oxygen:

$$
\mathrm{C}_{4} \mathrm{H}_{6} \mathrm{O}_{6}+\mathrm{O}={ }_{2} \mathrm{CH}_{2} \mathrm{O}+\mathrm{H}_{2} \mathrm{O}+{ }_{2} \mathrm{CO}_{8}
$$

Nutritive value depends therefore upon purely chemical properties, and I have here indicated one aspect of the matter. Such bodies as have little nutritive value can be utilized only with the aid of oxygen because, when they break up without oxygen, they can afford neither the chemical components necessary for the construction of protoplasm nor the necessary energy for construction of protoplasm out of other substances.

I have previously called attention to the 
physical point of view. It now appears clear from chemical considerations that in anaërobiosis, oxygen, to speak exactly, is not taken out of the molecule. There is simply an atomic rearrangement by means of which the hydroxyl radical $(\mathrm{OH})$ effects the oxidation of the carbon to carbon dioxide, and either hydrogen is liberated, or reduction products rich in hydrogen arise, or the hydrogen combines with sulphur to form sulphuretted hydrogen. The instability of the atom grouping is therefore the real, primary reason for the breaking $u p$, and this process is in certain cases independent of oxygen and can therefore proceed anaërobiotically.

The result is similar if a chemical body contains within its own structure the elements of formaldehyde and ammonia. Such a body for instance is asparagin, which is the amide of amido-succinic acid, and hence contains nitrogen which can be utilized in the same way as that of ammonia. Asparagin contains also the raw material of formaldehyde. Asparagin is aspartic acid monamide $\left(\mathrm{C}_{4} \mathrm{H}_{8} \mathrm{~N}_{2} \mathrm{O}_{3}=\mathrm{CH}_{2}\right.$. $\mathrm{CONH}_{2} \cdot \mathrm{CHNH}_{2} \cdot \mathrm{COOH}$ ), in which the hydroxyl $\mathrm{OH}$ in the carboxyl group $\mathrm{COOH}$ is replaced by the amido group $\mathrm{NH}_{2}$, and an $\mathrm{H}$ in the group $\mathrm{CH}_{2}$ is replaced by $\mathrm{NH}_{2}$. A part of the synthetic work therefore is already ac- 
complished in the existing condensation of the molecule. Asparagin, as compared with formaldehyde and ammonia, is one degree nearer to proteid. Conversely, asparagin arises out of proteid through oxidation. Schützenberger by artificially decomposing proteid, obtained a body related to succinic acid which had the empirical formula $\mathrm{C}_{4} \mathrm{H}_{7} \mathrm{NO}_{2}$. Löw considered this body as formed by molecular rearrangement of the hypothetical aldehyde of aspartic acid or of amido-succinic acid $\left(\mathrm{C}_{4} \mathrm{H}_{7} \mathrm{NO}_{4}=\mathrm{CH}_{2} \cdot \mathrm{COOH}\right.$. $\mathrm{CHNH}_{2} \cdot \mathrm{COOH}$ ), and has represented its probable significance in the building up of proteid in the formula already given (p. 93). According to Löw's conception, the chemical basis for the reactivity of active proteid lies in the association side by side, as shown in the foregoing formula, of the very reactive aldehyde and amido groups. For this reason, also, all those bodies which attack these two groups are protoplasmic poisons (cf. p. 85). It has been ascertained by Neelsen, Naegeli and Hueppe that asparagin is one of the best substances for the nutrition of bacteria, and that these organisms can construct out of it organic pigments and also, as Uschinsky has lately determined, proteid-like poisons. The nutritive value of asparagin is such that even some warm-blooded animals, such as cattle, can make use of it to 
a certain extent as a poor substitute for proteid; gelatin is the lowest substance of the kind utilizable by man.

The facts of fermentation became in Pasteur's hands the starting-point for conceptions which later were to revolutionize our way of looking upon the composition of chemical bodies. Pasteur found that in certain fermentations there was present, besides the active dextro-rotatory tartaric acid, the so-called active lævo-rotatory tartaric acid. These two acids combine to form the optically inactive racemic (paratartaric) acid. Pasteur accounted for this by the asymmetric structure of the chemical molecule. Out of this beginning Le Bel and van't Hoff developed the theory of the asymmetric carbon atom and modern stereo-chemistry. In spite of all the progress that has been made in developing synthetic methods, the destruction of inactive substances by fermentation and, by that means, the preparation of the optically active components has been held to as a rapid and important method in the domain of organic chemistry and still maintains this position. Schardinger discovered by this method the læevo-rotatory lactic acid which had never before been obtained chemically, and the existence of which was suspected only because the inactive lactic acid and the active dextro- 
rotatory lactic acid were known. In this connection it is also worthy of note that bacteria, yeasts and moulds exert a selective power in their action upon inactive bodies. If either yeast or the common blue-green mould (Penicillium g-laucum) is fed upon racemic acid, that is, upon a mixture of right and left-handed tartaric acid, the right-handed tartaric acid is used up and the left-handed remains behind; the same is true with methylpropylcarbinol and leucin. If the mould acts upon inactive amylalcohol or amygdalic acid, the left-handed modification is consumed and the right-handed is left untonched, while, if dealt with separately, the latter, which is not attacked in the mixture or inactive compound, can, when alone, serve as nutriment to the mould and be consumed by it.

The lævo-rotatory fruit-sugar as well as the dextro-rotatory grape-sugar is broken up by yeast in the alcoholic fermentation ; in a mixture of both, such as occurs in the invert-sugar of honey, the grape-sugar is fermented and the left-handed fruit-sugar remains unfermented. The same thing happens in a mixture of the right-handed galactose derived from milk-sugar with fruit-sugar, and this, in spite of the fact that when by itself, fruit-sugar is attacked by most yeasts more readily than galactose. The different geometric arrange- 
ments of the atoms in the several molecules only becomes manifest through the behavior of the substance in fermentation.

In order to construct a molecule of given constitution, however, differing amounts of energy, dynamically considered, must be expended according as the union of atoms be strong or feeble; and correlatively, this union of atoms can according to its firmness with greater or less ease be loosed again. If we consider two sugars of the same group and similar empirical composition, such for example as the hexoses or sugars containing six atoms of carbon, all of which have the same empirical formula $\mathrm{C}_{6} \mathrm{H}_{12} \mathrm{O}_{6}$, we can distinguish these as aldehyde sugars or aldoses (with the group $\mathrm{COH}$ ), and as ketone sugars or ketoses (with the group $\mathrm{CO}$ ). Thus, for example, grape-sugar, an aldose, possesses the formula $\mathrm{CH}_{2}(\mathrm{OH})$. $(\mathrm{CHOH})_{4} \cdot \mathrm{COH}$, while fruit-sugar, a ketose, has the formula $\mathrm{CH}_{2}(\mathrm{OH}) \cdot(\mathrm{CHOH})_{3} \mathrm{CO} \cdot \mathrm{CH}_{2}$ $\mathrm{OH}$. If we experiment with two such aldehyde sugars in which the inner stability of the molecule depends upon the opposite positions of certain atom groups, as is seen in grapesugar and galactose, we find that the comparatively unstable grape-sugar possesses, according to Stohmann, a greater store of energy than the more stable galactose; consequently 
less energy is needed to topple over the molecule of grape-sugar than the molecule of galactose. Grape-sugar, also, according to experiments which I have made, is more easily fermentable by yeasts than galactose, so that here also a choice of food-material occurs, the physical reason for which can be foreseen in the structure of the molecule. The same thing is true also among the so-called ketone sugars or ketoses; among the hexoses belonging to this group, the more unstable fruit-sugar possesses a greater store of energy than the more stable sorbinose (Stohmann). The former is easily fermentable, the latter difficultly so. E. Fischer and H. Thierfelder ${ }^{\mathrm{I}}$ have lately formulated this principle anew and have extended its application to several new kinds of sugars.

The celebrated investigations of $\mathrm{E}$. Fischer ${ }^{2}$ upon the so-called constitution or atomic structure of the sugar molecule require, then, for their full comprehension to be supplemented by Stohmann's investigations on the dynamic or energetical relations of the same molecule, and also by the biological facts which were first established by Pasteur. With knowledge of

1 Ber. d. Deutsch. Chem. Gesellsch., XXVII., I894, p. 2031.

2 Ber. d. Deutsch. Chem. Gesellsch., XXIII., I890, p. 2 I I 4, XXVI., 1894, p. $3^{189}$. 
two of these groups of facts, indeed, I was able some time since to infer the existence of the other group as a probable contingency, before such existence was directly ascertained. I mention this only to show how, in principle at least, the biologist is at no disadvantage in the matter of accurate prediction as compared with the physicist or astronomer. His method of reasoning is just as precise as that of a mathematician, but his material is for the most part too complex to admit of the use of mathematical signs. The demonstration of the possibility of such accurate forecasting establishes for us a certain security as regards the nature of our work. The unreasoning pride that too often lurks in a onesided mathematical formula need impose upon us no longer. There is, perhaps, a mathematics without the usual symbols. Far-seeing physicists, like R. Mayer, Helmholtz and E. Mach, have already recognized that, in order to be intelligible, physical observation must have its indispensable physiological side. In the monistic theory we possess a bond uniting not only all natural sciences with one another, but all the natural sciences with the so-called psychological sciences.

The cells of those animals and plants that lack chlorophyl are able, according to the cur- 
rent conception, to nourish themselves solely upon organic substances by the breaking down of these substances. Dujardin, however, as far back as I84I, discovered that bacteria can build up their body-substance out of ammonium oxalate. Oxalic acid is $\mathrm{C}_{2} \mathrm{H}_{2} \mathrm{O}_{4}=$ $\mathrm{COOH} . \mathrm{COOH}$, so that no formation of formaldehyde can occur through a simple rearrangement of the atoms. With the formation of the amido group, what probably happens is that since the oxalic acid in question is an ammonium salt, a reduction by the hydrogen of the ammonia occurs :

$$
\begin{aligned}
& \qquad \mathrm{NH}_{3}=2 \mathrm{NH}_{2}+\mathrm{H}_{2} \\
& \text { ammonia, amido group, hydrogen. } \\
& \begin{array}{l}
\text { COOH.COOH }+\mathrm{H}_{2}=\text { CHOH } \\
\text { oxalic acid, hydrogen, formaldehyde. }
\end{array}
\end{aligned}
$$

The further synthesis of proteid can afterwards proceed out of the formaldehyde and the amido group.

Again, formic acid cannot pass over into formaldehyde simply by atomic rearrangement, and yet $\mathrm{O}$. Löw has made the important discovery which rounds out this series of observations, that a bacterial species which can turn formaldehyde to account in constructing its Dody-substance can also make use of formic acid. Formic acid is $\mathrm{CH}_{2} \mathrm{O}_{2}$. Since it possesses both acid and reducing properties its 
constitutional formula can be written either $\mathrm{H} . \mathrm{COOH}$ or, to express its relations to the aldehyde group, HO.COH.

Compounds that contain both the aldehyde group $\mathrm{COH}$ and the carboxyl group $\mathrm{COOH}$ are aldehyde acids. We can therefore write two molecules of formic acid simply $2 \mathrm{H} . \mathrm{COOH}$ or $2 \mathrm{HO} . \mathrm{COH}$, or we may also, in accordance with the reaction in which it takes part, conceive it as an aldehyde acid, HO.COH-H.COOH. Within an organism, different sorts of reactions may well take place side by side while the chemist is able to determine their occurrence only separately in separate test-tubes. The following reactions may in this case occur directly :

I. $\mathrm{HO} \cdot \mathrm{COH}-\mathrm{H} \cdot \mathrm{COOH}=\mathrm{COH} \cdot \mathrm{COOH}+\mathrm{H}_{2} \mathrm{O}$ formic acid, formic acid, glyoxylic acid.

II. $\mathrm{COH} \cdot \mathrm{COOH}=\mathrm{CHOH}+\mathrm{CO}_{2}$ glyoxylic acid, formaldehyde.

Glyoxylic acid, the simplest of the aldehyde acids, may be an intermediate stage between formic acid and formaldehyde. Königs has already pointed out that in the green plants, glyoxylic acid arises through condensation of two molecules of formic acid. Formaldehyde might be obtained also, as stated above to bo the case with oxalic acid, by reduction of formic acid : 
$\mathrm{H} . \mathrm{COOH}+\mathrm{H}_{2}=\mathrm{CHOH}+\mathrm{H}_{2} \mathrm{O}$

formic acid, hydrogen, formaldehyde, water.

$$
\begin{gathered}
\text { IIO.COH } \\
\text { formic acid, }
\end{gathered}
$$

From formaldehyde upwards is consummated the synthesis of the carbohydrates, those substances devoid of nitrogen which are an important constituent of proteid and are fundamentally alike in green plants and in organisms which lack chlorophyl.

From the foregoing statements it might be taken for granted that formaldehyde marks the lowest limit at which chlorophyl-lacking organisms are able to begin the construction of organic substance, and that nothing but the presence of leaf-green or chlorophyl qualifies an organism for the assimilation of carbonic acid in combination with ammonia. But this limit does not exist. One of my pupils, Heraeus, made the observation, the significance of which he did not at first grasp, that even bacteria devoid of pigment can at times nourish themselves with ammonium carbonate. This power, I found, occurs only among the nitrifying microbes, which are able to oxidize ammonia to nitrous and nitric acid. I ascertained further that it is this combustion of ammonia that furnishes the energy for the synthesis and assimilation of carbonic acid and 
that the process is carried on through the utilization of formaldehyde. Owing to this peculiar method of obtaining energy the process is independent of light, indeed it is carried on better in the dark. From this we may recognize the fact that the assimilation of carbonic acid is a physiological property of all protoplasm, and that the chlorophyl function is an adaptation to life in the presence of light which has developed out of simple initial stages. In harmony with this view is Pringsheim's theory that chlorophyl is only a physical device for protecting the assimilating cell-protoplasm against too strong sun-rays which would eventually kill unshielded living matter. The injurious action of light-rays has been emphasized by bacteriology. That all energy is ultimately derived from the sun is a fact with which the development of individual adaptations has nothing to do ; in view of the vaporous atmosphere that prevailed in early geologic times, the first life upon the earth must have existed in the absence of direct sunshine, and only later could it have adapted itself to direct sunbeams. A connected history of the evolution of living things does not favor the conclusion, which the early botanists could not help drawing, that chlorophyl was the first created of organic bodies. 
In harmony also with the above facts, is the discovery of Engelmann that other pigments besides leaf-green are found among the lower plants, and that these pigments are, like chlorophyl, qualified by their physical power of absorption to aid in the assimilation of carbonic acid. Such pigments are found among diatoms and, according to Engelmann, the bacterio-purpurin of Beggiatoa is a pigment of this character. Chlorophyl, which has already been found in one bacterial species, the Bacterium chlorinum of Engelmann, was merely the one pigment which by adaptation and selection became favored quantitatively. These facts, discovered by Pringsheim, Engelmann and Hueppe, and the views advanced by these naturalists, have brought about a fundamental broadening of the scope of plant physiology.

The fact that nitrifying bacteria are able to utilize not only ammonium carbonate but even such compounds as carbon dioxide and ammonia was confirmed two years later by the Russian investigator Winogradsky, and supplemented in important particulars. He was greatly mistaken in his conception of the actual chemical process of synthesis, however, since he thought that urea was formed first, while, in reality, urea must be changed into 
-THE VITAL PHENOMENA OF BACTERIA. IO9

ammonia before it can enter into the proteid synthesis. Frankland and Löw have in this connection corrected my own earlier conception. I had found no nitrous acid as an intermediate stage and had therefore supposed a direct oxidation of the ammonia to occur :

I. $\mathrm{NH}_{3}+\underset{\text { ammonia, }}{2 \mathrm{O}_{2}}=\underset{\text { nitric acid. }}{\mathrm{HNO}_{3}}+\mathrm{H}_{2} \mathrm{O}$

II. $\mathrm{CO}_{2}+\mathrm{H}_{2} \mathrm{O}=\mathrm{H}_{2} \mathrm{CO}_{3}=\mathrm{CH}_{2} \mathrm{O}+\mathrm{O}_{2}$ carbon dioxide, water, carbonic acid, formaldehyde, oxygen. while Löw supposes :

I. $2 \mathrm{NH}_{3}+2 \mathrm{O}_{2}=2 \mathrm{HNO}_{2}+2 \mathrm{H}_{2}$ ammonia, oxygen, nitrous acid, hydrogen

II. $\mathrm{CO}_{2}+2 \mathrm{H}_{2}=\mathrm{CH}_{2} \mathrm{O}+\mathrm{H}_{2} \mathrm{O}$ carbon dioxide, hydrogen, formaldehyde, water.

The further synthesis of carbohydrates and proteids is carried out in the way previous1y stated. Perhaps the possibility of both methods of oxidation should be taken into consideration, for I at least entirely overlooked the nitrous acid, while Winogradsky now supposes that two kinds of bacteria exist, the one of which oxidizes ammonia only as far as nitrous acid, and the other oxidizes nitrous acid to nitric acid. According to Winogradsky, the oxidation of 35.4 milligrams of nitrogen is necessary in order to bring I milligram of carbon into organic combination. The matter has a practical interest since, by the use of material which contains the nitrifying bacteria as a fertilizer, it is possible to increase 
the yield of many kind of soils. Burri and Stutzer claim that in the reduction of nitrate through nitrite to ammonia, two kinds of bacteria are able to work symbiotically.

This discovery has had still another interesting consequence. The French investigators Schlösing and Müntz had previously championed the view that microbes play a rôle in the disintegration of rocks. Since, however, it was believed that chlorophyl-lacking microbes were not able to assimilate carbonic acid, which in this connection might possibly be regarded as a source of carbon, they supposed a source of carbon existed in alcohol (!), and took great pains to show that alcohol is an uncommonly widely distributed product and occurs everywhere over the earth. The matter was novel and the argument so ingenious that serious German periodicals immediately reported it to their readers without heeding the derision of every sound critic. The microbes that take part in the disintegration of rocks are perhaps just as well able to assimilate ammonium carbonate as those nitrate-forming bacteria found in the soil and between the floors and ceilings of our dwellings. Several years after, the question was cleared up by new investigations, and upon the appearance of Winogradsky's work, Schlösing and Müntz changed their views. 
Winogradsky has discovered that there are other sources of energy besides the sun's rays and the oxidation of ammonia which are available for purposes of organic synthesis. He found that the iron bacteria, Crenothrix and Leptothrix ochracea, which sometimes bring about the dreaded "water calamity"as, for example, that in the Berlin supply from Lake Tegel-can obtain their energy by oxidation of ferrous compounds to ferric compounds, as e. g. from ferrous carbonate to ferric hydroxide : $2 \mathrm{FeCO}_{3}+3 \mathrm{H}_{2} \mathrm{O}+\mathrm{O}=\mathrm{Fe}_{2}(\mathrm{OH})^{6}+$ ${ }_{2} \mathrm{CO}_{2}$. The presence of iron in the sheath of Crenothrix had been previously recognized by Zopf as a phenomenon probably of significance to the life of the bacterium. In this way the iron algæ and the iron bacteria share in the formation of the phosphates and silicates of iron deposited in the old morasses, and, from this point of view, they belong to those microbes concerned in rock-formation and the building up of the earth's crust.

The Beggiatoa or sulphur bacteria, some of which are devoid of pigment and some colored by bacterio-purpurin, are able to obtain their energy through the oxidation of sulphuretted hydrogen and then of the sulphur grains thus formed to sulphuric acid. To this oxidative process may be due the appearance of the sul- 
phur grains in Beggiatoa and their subsequent disappearance. The formation of sulphuretted hydrogen by the breaking up of proteid or by the reduction of sulphates is accomplished by various kinds of bacteria; the process of oxidation may, be considered as taking place in two stages :

I. $2 \mathrm{H}_{2} \mathrm{~S}+\mathrm{O}_{2}=2 \mathrm{H}_{2} \mathrm{O}+\mathrm{S}_{2}$ sulphuretted hydrogen:

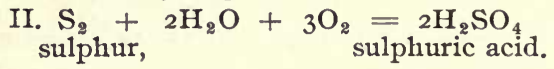

The process of the reduction of sulphates is carried on also by Beyerinck's Spirillum desulfuricans, the sulphuretted hydrogen being able to attack the iron salts with consequent formation of sulphide of iron. In this case, however, ammonium carbonate cannot be utilized for synthesis, so that physiologically we are here dealing with a higher stage of organization. Engelmann suggests that intermediate stages may perhaps be found among the splendid purple-red Beggiatoa.

Bacteria take part in yet another way in the formation of the earth's crust. If cellulose be decomposed by bacteria under water and in the absence of air, not only acetic acid, butyric acid and carbonic acid are formed, but also hydrocarbons, methane (marsh-gas or fire-damp) and coal; bacterial processes of this nature, then, 
mark the beginning of coal formation. Van Tieghem, by the microscopic examination of coal, has shown that such bacterial relations really do exist :

I. $21 \mathrm{C}_{6} \mathrm{H}_{10} \mathrm{O}_{5}+\mathrm{IIH}_{2} \mathrm{O}=26 \mathrm{CO}_{2}+\mathrm{IOCH}_{4}+\mathrm{I} 2 \mathrm{H}$ cellulose, water, marsh-gas, hydrogen $+\mathrm{I}_{9} \mathrm{C}_{2} \mathrm{H}_{4} \mathrm{O}_{2}+\mathrm{I}_{3} \mathrm{C}_{4} \mathrm{H}_{8} \mathrm{O}_{2}$

acetic acid, butyric acid.

II. $\mathrm{C}_{6} \mathrm{H}_{10} \mathrm{O}_{5}+{ }_{4} \mathrm{H}_{2} \mathrm{O}={ }_{3} \mathrm{CO}_{2}+{ }_{3} \mathrm{H}_{2} \mathrm{O}+4 \mathrm{H}_{2}+$ cellulose, water, carbonic acid, water, hydrogen, $\mathrm{C}_{3} \mathrm{H}_{4}$

hydrocarbon.

III. $\mathrm{C}_{3} \mathrm{H}_{4}+2 \mathrm{H}_{2}=\mathrm{C}+2 \mathrm{CH}_{4}$

hydrocarbon, hydrogen, coal, fire damp.

Gintl looks upon the carbonic acid developed by this process as the chief source of the carbonic acid occurring in natural mineral waters which are derived from strata of moor-coal or bituminous coal.

Blachstein ${ }^{\mathrm{I}}$ has discovered that various inorganic salts are often of the greatest significance for the life of bacteria, and that their correct selection determines whether or not some of the disease-producing bacteria retain their virulence. Kühne ${ }^{2}$ and yet more successfully, Proskaner ${ }^{3}$ succeeded in bringing about growth of the tubercle bacillus by taking glycerin or starch as the basis of a nutrient solution and adding to it asparagin or ammonium lactate, tartrate, malate or even oxalate. Or if other

${ }^{1}$ Berl. klin. Wochenschr., I894, No. 17.

${ }^{2}$ Zeitschr., f. Biol., XXX., p. 239.

${ }^{8}$ Zeitschr., f. Hyg., XVIII., p. I 28. 
sources of carbon were used, other nitrogen salts might be employed.

Bacteria, then, are able to construct their body substance out of various kinds of nutrient materials and also to produce the organic pigments, or fermentation products or poisons especially characteristic of individual species, and they are able to do this either analytically or synthetically with almost equal ease. This ambidextrous metabolic power exists among bacteria to an extent known as yet among no other living things, and these organisms consequently occupy physiologically even more than morphologically a kind of intermediate place between animals and plants. We know, of course, that every animal and plant cell works analytically as well as synthetically and that the earlier abrupt distinction between animals and plants, according to which the former were supposed to be mechanisms adapted for oxidation, the latter mechanisms for reduction, does not exist. Nevertheless, the differences between the two groups are considerable.

Among bacteria themselves differences in this respect may be remarked. While certain species appear able to work synthetically just as easily as analytically, there are some kinds which are better adapted to the one me- 
THE VITAL PHENOMENA OF BACTERIA. I I 5

thod, others to the other. In the decomposition of dead organic substance, a process which in the form of putrefaction and decay is an intermediate link in the cycle of animal and plant life, certain species are better fitted to break down the complex compounds present at the start while others, work up the end products. According to the discoveries of Heraeus, Hueppe and Winogradsky the nitrifying bacteria are best fitted for the last part of the process; and the iron and sulphur bacteria stand next above in the series.

Through the beautiful investigations of Hellriegel and Wilfarth we know that in the root tubercles of the Leguminose and some other plants, bacteria are found which have entered into an intimate union or symbiosis with these plants. By their aid the plants are able, even when growing upon poor soil, to avail themselves of atmospheric nitrogen for the synthesis of proteids, while their chlorophyl enable them to use synthetically the carbon dioxide of the atmosphere. This discovery has been turned to good account and marks one of the notable advances in agriculture. By inoculation of the soil with material containing the bacteria of the root tubercles, and likewise by cultivation of the useful plants upon which these microbes are symbiotic, the yield 
of many poor soils may be considerably increased without the application of manure. In Germany Schulz has accomplished this profitably with the use of lupine. In order to maintain the existence of those plants which are not possessed of such direct bacterial assistance, nitrogen in the form of saltpeter must be artificially added to the soil, or else we must supply manures rich in organic substances and out of which ammonia can be produced by bacterial decomposition, the ammonia being in turn oxidized to saltpeter in the soil by the nitrifying organisms.

When ordinary organic substances are decomposed, several species of microbes generally take part in the process, some species working together and simultaneously. This coöperative activity is called symbiosis. In the process of saké manufacture in Japan, a mould, Aspergillus Oryza, first inverts or converts to sugar the starch of the cooked rice, and out of this sugar a species of bacterium then forms lactic acid and a yeast alcohol. According to Juhler this yeast is perhaps only a yeast form belonging to the Aspergillus itself and not another species. In the manufacture of arrack in Java and saké in China, a species of Mucor, according to Eijkmann, furnishes the invert ferment, while the fermentation of the molasses is 
caused by a yeast of unknown species together with a branched bacterium (Fig. 22). In the preparation of the Eurasian beverage kumiss out of mare's milk, and the drink called omeire made out of cow's milk in southwestern Africa, a bacterium and a yeast act together, producing lactic acid and alcohol out of the lactose. A true coöperative growth occurs also in the case of the so-called kephir grains, a symbiotic union of yeast and bacteria which together accomplish a fermentation of the milk-sugar of cow's milk with formation of lactic acid and alcohol; these kephir grains have been artificially cultivated in Caucasus for centuries. According to investigations by Duclaux, Adametz, Grotenfelt and Beyerinck, there are also some yeasts which can form both alcohol and lactic acid out of milk-sugar, and are therefore able to produce unaided by any bacterium the alcoholic fermentation of milk.

When different species, adapted for different processes, follow one another in sequence the phenomenon is called metabiosis. The end members of this series, those which are best adapted to the beginning and those best adapted to the close of decomposition, are often in a sort of opposition or antagonism. In the decomposition of organic matter, such an opposition outwardly exists between those organisms that 
initiate the putrefaction of proteids and the synthetically-working nitrifying bacteria; frequently also an antagonism is manifested between pathogenic bacteria and the bacteria of putrefaction. Another sort of antagonism may be said to exist between the species that live with and those that live without oxygen, as Pasteur long ago proved.

\section{Active Proteids, Ptomains, Leucomains.}

By the decomposition of proteids, bodies are formed which must themselves be regarded as proteids and which are powerful poisons. The effect wrought by most pathogenic bacteria is due to the formation of poisons of this nature. Toxic albuminous bodies were first demonstrated by Bruylant and Venneman in I884, then in $\mathrm{I} 886$ by Weir-Mitchell and E. T. Reichert $^{\mathrm{I}}$ in snake-venom, by Warden and Waddel1 ${ }^{2}$ and by Sidney Martin. ${ }^{3} \quad$ Later the presence of such bodies was demonstrated in plants by Kobert and Stillmark, and in I888 the poisonous quality of the blood-serum of the eel was observed by Mosso. ${ }^{4}$ These observations, which seemed to contradict everything that previously and with reason had been believed in

${ }^{1}$ Smithsonian Contrib. to Knowledge, 1886.

2 Maly's Jahresb., 20, 313.

8 Proc. Roy. Soc., May 22, I89o.

4 Arch. f. Exper. Pathol. u. Pharm., 25, III. 
regard to albuminous bodies as nutrient substances, were at first neglected, and were even regarded by Brieger as gross chemical errors. Little confidence was at first placed in the idea of the existence of active proteid bodies, although Pflüger suggested it in I875, and Löw plainly expressed it in I887; the older works upon fermentation were allowed to lie neglected.

Nencki ${ }^{\mathrm{I}}$ and later, but much more thorough$1 y$, Brieger ${ }^{2}$ and Vaughan ${ }^{3}$ succeeded in preparing organic bases of a definite chemical composition out of putrid fluids, putrid meat, fish, shell-fish, old cheese, spoiled milk, and out of bacterial cultures. These were found to exert a poisonous effect and for a long time were looked upon as the true bacterial poisons. These poisons are particularly interesting since they may be present in the decomposing cadaver (hence the name ptomain) and, in consequence, have to be taken into consideration in questions of legal medicine. Or they may be found in the living human body, and, if not made harmless by breaking up and oxidation, may come to act therein as self-poisons or leucomains. But they are not the substances to

1 Jour. f. prakt. Chemie [2], 20, p. 454.

2 Untersuchungen über Ptomaine, Berlin, 1885 and 1886.

3 Trans. Seventh Int. Congress of Hygiene, 3, p. 118. 
which the peculiar poisonous effect of bacteria is to be ascribed.

Over fifty such ptomains are known already, and the empirical formula of each made out, and among them are some whose exact chemical composition is established. The first of these bodies to be separated was collidin $\left(\mathrm{C}_{8} \mathrm{H}_{11} \mathrm{~N}\right)$, obtained by Nencki. Trimethylamin $\left(\mathrm{C}_{3} \mathrm{H}_{9} \mathrm{~N}=\left(\mathrm{CH}_{3}\right)_{3} \mathrm{~N}\right)$, gives an odor like herring brine. Especially interesting is the substance cadaverin, which was separated by Brieger from portions of decomposing dead bodies and from cholera cultures, by reason of the fact that Ladenburg prepared it synthetically and showed it to be pentamethylenediamin $\left(\left(\mathrm{NH}_{2}\right)_{2}\left(\mathrm{CH}_{2}\right)_{5}\right)$. The substance methylguanidin $\left(\mathrm{C}_{2} \mathrm{H}_{7} \mathrm{~N}_{3}=(\mathrm{NH})_{2} \cdot \mathrm{C}\left(\mathrm{NH}_{2}\right) \mathrm{CH}_{3}\right)$, already known as an oxidation product of creatin, was also isolated from decomposing fluids and from bacterial cultures. The cholin group is particularly interesting. Cholin itself $\left(\mathrm{C}_{5} \mathrm{H}_{15}\right.$ $\mathrm{NO}_{2}$ ), arises from the hydrolytic breaking-up of lecithin, the fatty substance found in brain tissue and other nervous tissue (p. 87). The constitution of cholin is trimethylethoxy-ammonium hydroxide $=\left(\mathrm{CH}_{2}\right)_{2} \cdot \mathrm{OH} \cdot \mathrm{N}\left(\mathrm{CH}_{3}\right)_{3} \cdot \mathrm{OH}$. From the brain also Liebreich and Bayer separated neurin $\left(\mathrm{C}_{5} \mathrm{H}_{13} \mathrm{NO}\right)$, and Bayer showed this to be trimethylvinyl-ammonium hydroxide 
$=\mathrm{C}_{2} \mathrm{H}_{3} \cdot \mathrm{N}\left(\mathrm{CH}_{3}\right)_{3} \cdot \mathrm{OH}$. Cholin is only slightly toxic, neurin intensely so. Through the removal of water from the molecule and the consequent molecular rearrangement the slightly poisonous body becomes intensely poisonous:

$$
\underset{\text { cholin, }}{\mathrm{C}_{5} \mathrm{H}_{15} \mathrm{NO}_{2}-\underset{\mathrm{H}}{\mathrm{H}} \mathrm{O}=\underset{5}{\mathrm{C}_{5} \mathrm{H}_{13} \mathrm{NO} .} \text { neurin. }}
$$

Bayer also artificially converted cholin into neurin.

By the oxidation of cholin, there can be produced the non-poisonous betain or trimethylglycocoll occurring in beet juice, and the highly toxic muscarin, found by Schmiedeberg in a poisonous toadstool, and by Brieger in certain decomposing substances:

$$
\begin{gathered}
\mathrm{C}_{5} \mathrm{H}_{15} \mathrm{NO}_{2}+\mathrm{O}_{2}=\mathrm{C}_{5} \mathrm{H}_{11} \mathrm{NO}_{3}+\mathrm{H}_{2} \mathrm{O} . \\
\text { betain. } \\
\begin{array}{c}
\mathrm{C}_{5} \mathrm{H}_{15} \mathrm{NO}_{2} \\
\text { cholin, }
\end{array}=\underset{\mathrm{O}}{\mathrm{C}_{5} \mathrm{H}_{15} \mathrm{NO}_{3} .} \text { muscarin. }
\end{gathered}
$$

Upon the common base of trimethylethylammonium hydroxide the structural formulæ, according to Vaughan, are capable of giving an idea of the actual relationship to one another of these non-poisonous, slightly poisonous, and very poisonous substances:

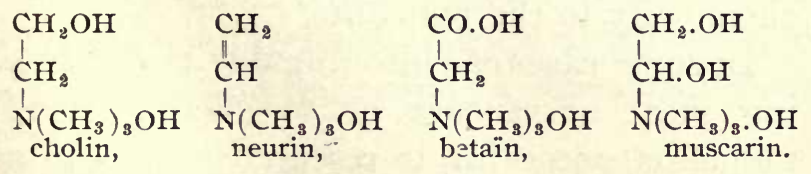

Frequently referred to, also, is the substance 
spermin, which, according to Kobert, is identical with piperazin or diethylene dimin $\left((\mathrm{NH})_{2}\right.$ $\left.\left(\mathrm{CH}_{2}\right)_{4}\right)$. Poehl, however, disputes this identity and ascribes to the substance the formula $\left(\mathrm{C}_{5} \mathrm{H}_{14}\right.$ $\left.\mathrm{N}_{2}\right)_{\mathbf{x}}$. The substance tyrotoxicon, discovered by Vaughan in cheese, seems to be derived from butyric acid or butyl-aldehyde.

It is a curious fact that a colored alkaloid base or ptomainic pigment has been discovered, the so-called pyocyanin $\left(\mathrm{C}_{14} \mathrm{H}_{14} \mathrm{~N}_{2} \mathrm{O}\right)$, which produces the color of blue or blue-green pus and has been regarded by Ledderhose as related to the coal-tar products. Similar bodies of a basic nature may be found in the intestinal contents as the products of bacterial decomposition. Some of these are poisons, and can be absorbed into the body, where they play the rôle of self-poisons or leucomains. Perliaps the symptoms designated as coma and tetany may be ascribed to something of this nature. Katabolic products also sometimes originate in the body which may accumulate in great quantities, and produce auto-intoxication and fatigue. Some of these substances are related chemically to the ptomains.

In some cases of poisoning due to decomposing meat or sausage, or to cheese or milk, ptomains, according to researches made in my laboratory, may not be concerned at all, or if 
so, perhaps only secondarily, and other bodies, the poisonous proteids, may be the real cause. Such poisonous proteid bodies are always formed in the beginning of decomposition processes. They are to be considered as "active" proteid bodies, having in part an enzymotic action, and their activity is destroyed by high temperatures.

Christmas $^{\text {I }}$ and Hankin ${ }^{2}$ were the first to discover that pathogenic bacteria also form such primary proteid-like poisons, or, to express it more accurately, form poisons which till now we have not been able to separate from proteid bodies. These bodies likewise are to be considered as active proteids. Here belong the poisons of diphtheria, tetanus and cholera. The activity of these poisons, too, is destroyed by heating; and the active proteid clianged to the passive form.

The emphasis is to be laid upon "active". proteid in contradistinction to "passive" proteid. The classification of the proteid bodies, worked out by Hoppe-Seyler and W. Kühne, has hitherto taken into consideration only the passive proteid bodies. This sc'leme does not include the "active" proteids which we know as poisons, and under such a classification cer-

1 Ann. de l'Inst. Pasteur, I89I, p. 487.

2 Brit. Med. Jour., 1889, p. 810. 
tain of these bodies could not be called proteids at all. To illustrate, if certain bacteria are cultivated upon proteid-free nutrient media, such as ammonium lactate or asparagin, poisonous substances are usually produced, but proteid reactions are not always obtained from the filtered solutions. On the other hand, it is positively established that the poison always constitutes only a slight fraction of the whole solution. In solutions containing proteid there is always some poison side by side with much proteid, and the intensity of the reaction has often been falsely attributed to the quantity of the latter, for we know of no chemical method by which we are able to distinguish between the poisonous active proteid and the non-poisonous passive proteid of the same group. A very slight amount of poisonous proteid, however, in another solution may elude our test for proteid. So, for example, one part of rennet curdles two million parts of casein ; according to Vaillard, there is contained only $0.00025 \mathrm{gr}$. of the solid tetanus toxin in a dose fatal to a guineapig; and according to Kobert and Stillmark, $0.00003 \mathrm{gr}$. of ricin per kilogram of bodyweight of the anima! is fatal when injected into a vein. Such slight quantities may well escape the coarse reactions of proteid chemis- 
THE VITAL PHENOMENA OF BACTERIA. 125

try, although in experiments with animals they can be unmistakably detected. For these reasons we can and indeed must make our conception of these poisons, the " active proteids," a wholly provisional one. They are certainly to be referred to the coagulable proteids, and are less resistant to heat than the poisons belonging to the group of albumoses and peptones. Their extraordinary "activity" recalls that of the enzymes, and for this reason Roux has considered that the diphtheria poison, and Nencki that all these poisons are of an enzyme character. But to regard them as enzymes does not altogether free us from difficulty. The fact of their extraordinary activity still faces us, whether we call these poisons enzymes in the earlier limited sense in which that term was used, or whether, on account of our more extended knowledge of activity on the part of proteid bodies, we fall in with Nencki's suggestion and widen our conception of the nature of an enzyme.

\section{Effect of Bacteria upon the Substratum.}

From the earliest observers (among whom I need mention only Leeuwenhoek, O. F. Müller, von Gleichen-Russworm, Ehrenberg and Dujardin) of "infusion animals," the name under which for a long time bacteria were classed, 
down to Ferdinand Cohn, Josef Schröter and Robert Koch there have always been investigators who supposed a rigid constancy of form and species. These observers, moreover, established genera and species as had been done in the first instance, directly according to form, and thus came about the conception of form-genera and form-species, the individual forms of which were supposed to be always the same. So long as this idea prevailed, whenever novel forms were observed after an alteration of the conditions of nutrition, they were referred to the intrusion of germs of other species; the occurrence of unusual fermentative effects was also taken for a proof that foreign germs had stolen in. Definite forms and uniform effects were supposed always to coincide. Under the influence of this conception F. Cohn divided bacteria, according to the effects they produced, into pigment-forming or chromogenic, fermentation-provoking or zymogenic and disease-producing or pathogenic. Thus by the aid of physiological characteristics, he obtained a more extended application for his classification into form-species, especially as regards those forms that, on account of their minuteness, did not admit of sharp distinction. Many of the species thus obtained are, it is true, collective, and with more 
accurate knowledge have been resolved into several species; here belong for example, $B$. termo, $B$. subtilis or the hay-bacillus, $B$. mesentericus or the potato-bacillus; to-day such names are sometimes used in a general, sometimes in a limited sense.

At first stress was laid upon differences and it was recognized that different genera and species exist among bacteria as well as among the Cyanophycea or among the moulds. These discoveries, which were supported by careful methods devised by J. Schröter and ingeniously extended by Klebs and especially by R. Koch, formed a basis for all subsequent investigation. The further discoveries of J. Schröter and Hueppe concerning the pigment bacteria, of Pasteur, F. Cohn, Fitz, Duclaux and Huepperegarding the processes of fermentation and decay, and of Davaine, Pasteur, R. Koch, Gaffky and Löffler in regard to disease-producing bacteria, established bacteriology upon a firm foundation.

It was supposed, however, in the beginning that in every typical fermentation or infectious disease only one kind of micro-organism was causally concerned. But Mitscherlich had even then discovered that the yeasts of top and bottom fermentation are of different species, and $I$ too found that not one species merely, 
but a whole series of bacteria are able to form lactic acid out of sugar; and the same thing was later ascertained in regard to other kinds of decompositions. In the lactic fermentation the kind of sugar determines the nature and course of the process, and from the bacteriological point of view it might almost be said that every germ that produces lactic acid seems to prefer a special kind of sugar. Hansen has lately found a new germ which is capable of causing the oxidation of alcohol to acetic acid, and which is the third germ known to possess this power as two others had been previously discovered,- - one by Kützing and one subsequently by Pasteur.

The same thing has been shown to be true of the power to produce disease, and the once prevalent conception of "specific" germs of fermentations, pigments, and diseases, has been completely shattered.

There are certain well-known fermentations evoked by bacteria, the chemical side of which formerly attracted most attention. These are especially the lactic acid fermentation of sugar, in which alcohol and acetic acid often appear as by-products; the alcoholic fermentation of sugar, in which lactic acid is always produced as a by-product; the butyric acid fermentation of sugar and lactic acid salts; the forma- 
tion of alcohol and butyric acid from glycerin; the viscous fermentation of sugar with formation of gum or mannite; the dextrine fermentation of carbohydrates; the viscous fermentation of proteids; the blue and red coloration of milk (the latter may be due to different causes); the formation of blue cheese; the fluorescence and phosphorescence shown in some culture media; the production of ammonia and sulphuretted hydrogen; and the formation of nitric and acetic acids.

As regards the occurrence and distribution of bacteria, it may be said in general that these organisms are to be found almost everywhere. They are present in the soil, in the water and in theair. Differences in distribution, however, do occur. In the upper layers of the soil are found not only enormous numbers but many different kinds of germs favored by the fluctuations in humidity and by the varying temperature. Here in the ground they take part in the decomposition of organic substances, and convert these to ammonia, oxidize the ammonia to nitric acid, and form carbonic acid; indeed, we may look upon bacteria as the most important promoters of the decompositions called putrefaction and decay. The ground, however, acts upon bacteria like a filter, so that the number quickly diminishes from above down- 
wards, and the ground at a depth of from four to six meters is germ-free. From the soil the bacteria may pass into the water, and we everywhere find in water the same germs as in soil, unless the water be derived from the deeper germ-free layers. In water, just as in soil, bacteria share in the decompositions of organic substance and aid in the transformation of inorganic compounds of sulphur and iron. In the ooze at the bottom of rivers and lakes, where there is lack of oxygen, they bring about the formation of marsh-gas, hydrogen, and sulphuretted hydrogen, and so take the first step in the beginnings of coal-formation. The number of individual germs, and of species, in water and soil depends largely upon the amount of decomposable substances present in the surroundings. In the neighborhood of our dwellings, in the tracts of low land about rivers and lakes, and in river deltas, there is a high percentage of such substances, and in such localities we meet active decomposition and most luxuriant bacterial vegetation. Many species, like $B$. termo, the hay bacillus, and the earth bacillus, are apparently spread over the whole world, others are very rare or limited to special localities. The true home of the comma-bacillus of Asiatic cholera, for instance, seems to lie in the notorious Sunderbunds of the Ganges. 
Other foci of decomposition probably have their own bacteriological peculiarities which make them the home of special germs. The germs causing malignant œdema and lockjaw are often found in the earth of gardens. I once happened to find the extremely rare bacterium of the "blood portent" ( $B$. prodigiosus $)$ in a well in Wiesbaden. Other rare species occasionally appear upon our nutrient media without our being able to ascertain their origin, and then fail to put in an appearance again for years.

In general the germs provoking fermentation and disease must be reckoned among the rarer species. This is true at least in so far as that such germs generally maintain their power only if they have frequent opportunity to evoke fermentations or diseases. Such opportunity implies the existence of course, of some sort of industry however primitive, which is dependent on fermentation, or of a certain aggregation of men and animals on which to live.

Even a very rapid flow of air is unable to detach a single bacterium from a moist surface, but when the soil or the margin of pools becomes dried up, germs may pass into the air along with the dust; the only other way in which bacteria can enter the air is through the 
spraying of water. Bacteria are very variously distributed in the air according to the degree of atmospheric purity; their number decreases at high altitudes, and B. Fischer found that the air over the sea at some distance from land was germ-free.

\section{Practical Applications.}

Many bacterial discoveries are of direct practical importance. As the fermentation industries have been built up through the investigations of Pasteur and Hansen upon yeasts, so the fundamental work of Duclaux and Hueppe upon the fermentations of milk and cheese has paved the way for a complete revolution in the dairy industry. ${ }^{\mathrm{I}}$

A well-known practical result of bacteriological research is the sterilization of milk. Before the discovery was made that it is possible to sterilize milk by temperatures below the boiling point and it was known under what conditions this could be done, this method had been declared by Pasteur to be inapplicable to milk, and its impracticability, as was thought, firmly established. Tyndall is largely responsible for the working out of this method of

1 To forestall the criticism that this conception is onesided, it is necessary merely to mention the fact that other important improvements have been wrought on the dairy farm by the introduction of the separator, and by better methods of housing and feeding stock. 
THE VITAL PHENOMENA OF BACTERIA. I 33

pasteurization as it is called. I was able to determine further the exact temperature at which milk can be made germ-free and showed that, in order to obtain milk that would keep and remain fit for transport, a temperature of $\mathrm{I}_{2} \mathrm{O}^{\circ}$ is necessary; otherwise, condensation must be resorted to. Shortly before the appearance of my work, Soxhlet had attributed the well-recognized success that attends the pasteurization of milk to the subsequent chilling of the fluid; later, upon the basis of the facts I had ascertained, he introduced the method of treating children's milk which goes by his name. This, as a matter of fact, was nothing more than an exploitation of my discoveries, which I had freely placed at the disposition of every one.

Naegeli observed, as Pasteur had done before him, that milk that has been heated does not afterwards become acid, but, on the contrary, alkaline, and he assumed that the germ that produced acid had been so modified by the heat that its ferment-nature had undergone metamorphosis. My own investigations have made the following point clear, namely, that the germs producing acid are actually destroyed by the heat, but that resistant spores of other bacteria are present along with them in the milk, and that these spores resist the heat, subsequently germinate and thereby render 
the milk alkaline and bitter. The bacterial species concerned in this matter, and which belong in great part to the general group of hay or potato bacilli, were later studied by Löffler, Weigmann, Krüger and Flügge. Flügge and I together ascertained that some of these bacteria could form not only bitter substances but also proteid-like poisons. Milk usually becomes bitter because of the formation of peptones; according to von Freudenreich, however, certain bacteria may form other bitter substances.

Important work was done upon the lactic acid fermentation by my pupils, Scholl and Grotenfelt, and later by Weigmann, Krüger, Conn and Kaiser; Grotenfelt first, Weigmann later and more accurately, have established the fact that some of the germs which form lactic acid in milk and in various sugar solutions, produce a fine, aromatic odor. ${ }^{\mathrm{I}}$ I had already in I889 maintained before the German dairy association that dairymen ought to make use of pure cultures of such bacteria to bring about the souring of pasteurized cream in all places where butter is made out of sour cream (as is the case universally north of the Main and in Scandinavia). Grotenfelt has in-

1 Cf. Weigmann, Zum Butteraroma. Centralbl. f. Bakt., Abth. II, III., p. 497 . 
troduced into Finland this method of souring cream; Weigmann has recommended its use in Holstein ; and Stein and Boggild have introduced it into Denmark with marked success, so that butter made from such cream has, in the last year, gained everywhere a majority of the first prizes. In Germany, although the method in the first instance emanated from my laboratory, very little advantage has yet been taken of these facts. The circumstance that the dairymen themselves do not push the matter energetically, but are waiting for State initiative, is in part to blame for this condition. It is most necessary, however, to awaken the farmer, with or without State aid, as is proved by the whole situation of the butter question. The replacement of butter by " artificial butter" which, when real oleomargarine, is prepared out of beef fat, has not solved the question, for the simple reason that good beeffat is itself dear, and hence in the manufacture of oleomargarine, other fats, often of disgusting nature are always in part substituted for it. Consequently oleomargarine is as a matter of fact everywhere sold at prices above its real value and is not a fair substitute for butter. On the other hand, butter is often handled on small farms so badly, and with such lack of cleanliness, that we can certainly under- 
stand why, in view of this indifference of the producer, the consumer often prefers oleomargarine which, to say the least, is always appetizingly prepared.

In the ripening of cheeses, also, bacteria take part. ' Some kinds effect the natural ripening, that is, the transformation of the casein and the production of aromatic chemical compounds which impart the individual flavor to different cheeses, and some kinds bring about the various "diseases" of cheese, the ripening in wrong ways and the formation of poisons. The studies upon cheese bacteria have been carried forward especially by Freudenreich, Adametz, and Beyerinck. If we except the use of the "Edelpilz," a variety of the green pencil mould (Penicillium), in ripening Roquefort and Gorgonzola cheeses, then Persyn, with the aid and direction of Hueppe, was the first to put what was known in the matter to practical use by the employment of pure cultures of bacteria in the preparation of an Edam cheese to which prizes have been repeatedly awarded.

The rancidity of butter due to formation of fatty acid depends, according to Duclaux and Ritsert, upon the oxidation of the fat by atmospheric oxygen in the presence of light, and

${ }^{1}$ See also on this point, Babcock and Russell: "Unorganized Ferments of Milk: a New Factor in the Ripening of Cheese." Centralbl. f, Bakt., Abth. II., III., p. 615. 
in part also, according to Krüger and $\mathrm{V}$. Klecki, upon the production of acid from the milk-sugar. The first sort of decomposition can be avoided by careful exclusion of the butter from light and air, the latter by heating or addition of salt. The "rancidity" first mentioned was formerly confounded with real "acidity."

According to Haenlein, ${ }^{\mathrm{I}}$ we have reason to hope that the tanning industry also will derive practical benefit from bacteriology.

The steeping of flax-stems in water as preparation for retting is performed for the purpose of bringing about a process of bacterial decomposition, and accurate study of this process will perhaps enable us to isolate bacterial species specially fit for this purpose and to use them in pure cultures.

In all these cases in which pure cultures of bacteria are employed for reaching a desired specific effect, it is always our aim to obtain a definite species of bacterium and to utilize the constancy of this species to generate definite products; whence we might infer that the constancy with which a species produces pigment or fermentation or disease is absolute, and that the effect is wholly contingent upon the kind of bacterium present.

1 Centralbl. f. Bakt., Abth. II., I., p. 26. 
Cycles of Activity and Adaptation.

The fact, however, is quite otherwise. Perty, Billroth, and Naegeli long ago denied that constancy of species existed among bacteria. Billroth derived all disease-producing bacteria from a species named by him Coccobacteria septica, while Naegeli asserted that the form and action of bacteria vary without limit. Buchner was the first to succeed in treating the anthrax bacillus so that it lost its power to provoke disease and comported itself like a. mere bacillus of putrefaction. It is true he did not interpret this result correctly, since he was led to believe that the anthrax bacillus had been converted into the hay bacillus. Pasteur next observed that the bacteria of chicken cholera could be made to lose their ability to produce the disease, and later it was ascertained that nearly all of the disease-producing germs could be similarly attenuated. Fitz first established the same fact concerning the bacteria of the butyric acid fermentation, and Hueppe concerning the lactic acid germs, while Schottelius and Scholl proved the same thing concerning the pigment bacteria.

The ability of bacteria to form pigments, fermentation products, or poisons, either in their growth upon dead substance or in the 
living organisms, or to produce disease, is, as a matter of fact, variable. It can diminish, but it can also under some conditions increase.

Bacteria depend for their provision of food and energy upon the conditions of nutrition. If these conditions remain constant the action of the bacteria does not vary. If the conditions of existence do not remain constant, one of three things comes to pass. Either the bacteria change in form and action and adjust themselves to the new conditions, or they form spores which preserve the species until better times return, or they fail to adapt themselves at all and so perish. The various kinds of pigment, ferment, and disease-producing bacteria are therefore in fact not to be considered as species in the natural history sense, but as nutritional modifications.

For this reason we recognize the existence of complete "cycles of activity." According to Fitz the butyric acid germ forms butyric acid out of the saccharoses as the chief product, and butyl alcohol as a by-product; while out of glycerin it forms, besides butyric acid, much normal butyl alcohol, and as by-products propyl glycol and lactic acid. The bacteria of glanders form a brown pigment on potato, and their growth is accompanied by decrease of virulence; the yellow pus-coccus (Staphylococcus pyogenes 
aureus) forms a golden-yellow pigment, induces suppuration, and in sugar solutions produces lactic acid; the comma bacillus of Asiatic cholera causes disease in man, forms in its growth upon potato a yellowish brown pigment, and in sugar solutions produces lævo-rotatory lactic acid; the common bacillus of the colon ( $B$. coli communis) as a rule lives a harmless saprophytic existence in the intestine, but may also cause serious illnesses and inflammations, while in sugar solutions it can effect a lactic acid fermentation, and when grown on potato forms a dirty brown pigment. B. prodigiosus produces red spots upon substances rich in starch, such as potatoes or wafers, a phenomenon which in early times was regarded as the miracle of the bleeding host; when grown at higher temperatures it brings about vigorous lactic acid fermentation without any production of pigment. The mere fact that it is possible to obtain parasitic or zymogenic germs in pure culture, and to cultivate them as harmless saprophytes upon various lifeless nutrient media shows that it is impossible to divide-bacteria into physiological species according to their mode of action.

This is practically opposed to the ideas which were expressed cautiously by Ferdinand Cohn and Schröter, and more outspokenly by 
R. Koch. According to the conception advanced by the latter it is the bacillus, always constant, that is the "cause" of the typical or specific fermentation or disease: it alone produces the uniformity of effect. In reality the bacillus adapts itself to its surroundings and remains the same so long as they remain the same, but changes if they vary. The constancy of those external conditions to which bacteria must adjust themselves alone determines the uniformity of the effects produced.

The full significance of the foregoing facts may perhaps be gathered from the following considerations. If a person contracts a bacterial disease, tuberculosis for example, then, according to Koch, only the tubercle bacillus can be held responsible. It is just this belief that has made the science of bacteriology so popular in the eyes of the unreflecting multitude and of many easy-going physicians. We need no longer, it is supposed, be solicitous about our own mistakes and peccadilloes. Come what may, we are morally protected, and, secure in the consciousness of our individual merit, we now lay all responsibility upon "the bacteria " as formerly upon " catching cold." A fatal blow is dealt to these selfdeceptions and illusions by simply pointing to the fact that bacteria provoke fermentation 
only when they come in contact with fermentable substances under proper conditions, and produce illness and disease only when predisposition toward disease exists. Such liability or predisposition we may either inherit from others or acquire by faults of our own. Where no susceptibility to disease exists, we may harbor the bacillus with impunity. We should, then, revile the malicious bacteria nolonger, but take ourselves to task and mend our own ways. Not that, some measure of reform having been effected, we should behave ourselves irrationally for eleven months in the year, then go to a medical Tetzel and have prescribed as indulgence a four weeks' sojourn at a wateringplace. It is better for the majority of men to put themselves, through sensible ways of living, into such a condition that bacteria can get no lodgment in their system. This, in few words, is the practical lesson of bacteriological discoveries, Koch to the contrary notwithstanding. It is a less comfortable doctrine, but it is scientifically more nearly correct than the other.

The action of environment upon bacteria may be still further considered. If a bacterium that produces disease or that causes fermentation or that forms pigment be cultivated for a long time under conditions in which it 
cannot exert its peculiar activity, it generally adapts itself to the new conditions so completely that it entirely unlearns its original mode of action. In our laboratories many disease and ferment germs have become harmless saprophytes though long-continued cultivation in nutrient broth or gelatin. It is possible also, if the attempt be not too long delayed, to accustom these bacteria again to their original mode of activity by supplying their original conditions of life.

The form of bacteria, as well as their function, changes in response to changed conditions of life. The ray-fungus (Actinomyces) develops its characteristic form only in the animal organism. The so-called tubercle bacillus is not a bacillus at all from the point of view of bacterial classification, but a parasitic growth-form of a pleomorphic mould. It is now well established that there are species of bacteria that pass through only a small cycle of forms, while other species show many forms in the course of their development, a point that has been elucidated chiefly by the investigations of Zopf and Winogradsky. At one time pleomorphism was generally confounded with the variability of individual forms according to the substratum, an error to which an end was put some years ago by the demonstra- 
tion that pleomorphic species may be relatively constant in form, and, conversely, that the forms of simple species may be very variable. Buchner, Gruber and Metschnikoff have discovered important examples of this rule.

If the activities of bacteria be artificially modified,-if for instance, pathogenic bacteria be so attenuated that they have little. or no effect upon animals, -in such a case morphological changes in the germ may be regarded as degenerative; the species may not only be less virulent, but also grow more feebly. It is possible, however, to destroy the power of the "specific" action upon animal organisms while the bacteria themselves remain vigorous or indeed grow even more vigorously. In some cases of this sort, disease germs adapt themselves exclusively to decomposition and become mere saprophytes. The ability of bacteria to form pigments, fermentationproducts and poisons and to provoke disease is proved by accurate investigation to be simply a quality of adaptation, and a knowledge of this fact makes it possible for us to discuss scientifically the question, involved as it is at every point, of the causes of disease (Ch. IV.). Koch's belief that the "cause" of disease is the constancy of the "specific" disease-pro- 
THE VITAL PHENOMENA OF BACTERIA. I45

ducing bacteria renounces at the outset a scientific explanation. With the abandonment of Koch's position, which has been made inevitable by the facts discovered in the last teil years, bacteriology has progressed beyond the stage of a natural history subject and advanced to a truly scientific standpoint. 


\section{CHAPTER III.}

BRIEF DESCRIPTIONS OF THE MOST IMPORTANT PATHOGENIC BACTERIA.

THE starting-point of the discoveries enumerated in this chapter was the observation that definite bacteria with well-marked characteristics occur in certain diseases. For example, spirally twisted filaments were observed by Obermeier in the disease known as relapsing fever, rodlets were found by Koch in anthrax, and chain-cocci in erysipelas. The microbes which have been brought to light by investigation of this kind belong mostly to the class of bacteria. Such microbes found accompanying disease have been discovered successively not only in many epidemic diseases, but also in socalled organic diseases like pneumonia, and in constitutional diseases like consumption; and they have been found so situated that their causal connection with these diseases is generally acknowledged. Koch claimed that three points must be determined in order to afford proof of this causal relation : (I). The microbes 
should be found in such numbers and in such positions that their presence could explain the characteristic symptoms of the disease; (2) They should be grown in pure culture outside of the body; (3) These pure cultures, when inoculated into susceptible animals, should induce the same disease. Proof on each of these several heads could be furnished in the case of many diseases, for example, in the case of septicæmic diseases like anthrax and in tuberculosis. On the other hand, proofs on heads (2) and (3) failed in relapsing fever, proof (I) was not forthcoming for diphtheria and lockjaw, nor were proofs (I) and (3) for cholera.

It was necessary then to make a further advance. The fact that was first recognized, although it did not at once receive the attention it deserved, was the existence of a susceptibility to disease. Only if an animal was predisposed to "take" the disease in question could the disease be imparted to it. If an animal was not susceptible, it. was not made ill or affected by the bacteria in any way. It was next observed that certain bacteria did not produce their deleterious effect mechanically by their presence and increase in the organs, but rather chemically through the formation of poisons. (It is certainly remarkable that Koch who had made the first of these observa- 
tions in 1878 could yet in I 880 confidently advance his three requirements). The fact soon became manifest also that not all those bacteria which the microscope showed to be associated with certain diseases could be cultivated outside of the body; in such cases it was not possible to obtain pure cultures and infect animals with them. It became evident further that the bacterial forms themselves were not always distinct, typical and specific, and that the simple form-characteristics relied on in earlier times could not be made use of, but recourse must be had to other differential diagnostic characters. Many bacteria also were found to be commonly harmless, although able to cause disease under special conditions.

In the light of these discoveries, all our classifications of bacteria are seen to be beset with insuperable difficulties. If we classify according to bacterial genera, the germs of disease are widely separated from one another; if we classify according to diseases, the bacterial groups are broken up. Often one does not know, in a given disease, whether to attach more importance to the localization of the germs in single organs or tissues or to the general effect. The grounds for many of these perplexities will be explained-later very simply when I take up scientifically the dis- 
cussion of etiology. For the present, a preliminary survey is sufficient.

A primary distinction is often made between the truly infectious organisms, organisms namely which, when introduced in small num. bers into the body of men or the lower animals, can increase there abundantly; the poisonous or toxic bacteria which, when introduced even in small numbers into the body of the host, produce poison; and the phenomenon of intoxication or poisoning which is caused only by the direct incorporation of quantities of toxin. Virulence may be said in general to be the power to grow or produce poisons in the body.

Some bacteria produce ill effects by poisons which they generate outside of the body during the course of the decomposition of dead organic material, the organisms themselves not being able to grow in the animal body. A group of facts bearing on this point was first securely established by Panum ${ }^{\mathrm{I}}$ in 1874 . To this class belong many of the bacteria of putrefaction. In some instances after the body has been weakened by the poisons, these putrefactive bacteria may become able to multiply within the organism.

B. Proteus, discovered by $\mathrm{Hauser}^{2}$ in $\mathrm{I} 885$,

1 Virchow's Archiv, LX., p. 358.

${ }^{2}$ Ueber Fäulnissbakterien, 1885. 
was probably included at first in the collective species " $B$. termo." It forms spherical cells and rodlets which unite in long filaments, and belongs, therefore, among the arthrobacteria. Its vegetative rod-forms have numerous diffuse flagella; it liquefies gelatin, producing at the same time a carrion-like odor; it does not stain by Gram's method. If the organism is injected into the vein of a dog, the animal sickens with vomit and diarrhœa both accompanied by hæmorrhage and with yellow discoloration of the sclera. The same hæmorrhagic enteritis occurs when filtered cultures are injected, hence the inference that we have here a case of simple intoxication. In man, Proteus is sometimes found in purulent and malodorous phlegmonous inflammations, in the so-called putrid intoxications, in acute jaundice (Weyl's disease) where it occurs in the urine, and in some cases of rag-pickers' disease.

B. pyocyaneus, ${ }^{1}$ discovered by Gessard, is known both in the rod form and in the filamentous form and is also to be regarded as an arthrobacterium. It is characterized by the blue-green, sometimes leek-green color, that is developed in cultures (cf. pyocyanin p. I22). In rabbits it usually produces only a general

${ }^{1}$ Cf. Barker, Journ. of the Amer. Med. Assoc., XXIX., No. 5, p. 213. 
poisoning ; at times, however, it is very virulent and multiplies in the organism so that a true infection exists. It has been found in cases of general hæmorrhagic sepsis and severe diarrhœa in children; in such cases however the toxic action appears to be more conspicuous than the effects due to multiplication of the organism. Occasionally, it is found also in the inflammation of serous membranes, while upon wounds it attracts attention more by the discoloration of the bandages which it produces than by its growth.

In the case of these two putrefactive bacteria the distinction between intoxication, real toxic action, and real infection is not sharply marked. Only in regard to their occurrence in human beings need this distinction be taken into consideration; there they produce their effect chiefly through intoxication. In this connection it may be mentioned in passing that bacteria which are wholly without effect upon man and the higher animals, and which are for them neither infectious nor toxic, may yet be infectious for lower organisms, such as insects. An instance of this is the infection of flies by the hay bacillus.

Bacteria, which are neither toxic nor infectious may yet prove fatal to warmblooded animals when injected in very great 
numbers. In very large quantities bacterial protoplasm or bacterial proteid is, like any heterogeneous foreign proteid, poisonous to animals, as Hueppe has proved experimentally to be the case with a whole series of harmless bacteria and various kinds of proteids. Landois, Daremberg and Buchner discovered earlier that the blood-serum of one species of animal destroys the blood-corpuscles of another. For a similar reaso11, probably, dead cultures of $B$. prodigiosus or of the hay bacillus kill animals just as surely as dead cultures of pathogenic bacteria, and indeed just as surely as living infectious and toxic bacteria. In the conduct of experiments, therefore, it is necessary to consider not only the poison contained in the poisonous culture fluid, which is able to produce its effect after the bacteria have been removed by filtration, but also the quantity of bacterial protoplasm introduced into the body of an animal. The transitions from infection to intoxication, from disease to poisoning, are therefore manifold and various; and as a matter of fact these phenomena usually occur side by side.

A small number of bacteria is sufficient for infection. In many cases, experimentally well established, a single germ is able to provoke a disease. This is true as regards the 
infection of white mice with anthrax and young rabbits with chicken cholera. The bacteria multiply and overgrow the organs, generating during their growth poisons or toxins which cause the illness of the host, and, hand in hand with this multiplication, the older germs die off and also act injuriously for the reason that they are so much foreign protoplasm. In the course of multiplication the bacteria attack the proteid of the body and split off from it poisons, a process which can take place outside as well as inside the bacterial cells. This chemical action is at first a pure splitting, an anaërobic process. The bacteria are also able to consume the oxygen in the blood or tissue juices, and, in return, generate carbonic acid, so that an overloading of the blood with carbonic acid results in a development of heat, the latter phenomenon expressing itself in a rise of temperature, that is, in fever (C. Roser). But the poisons produced by the bacteria are also able to stimulate the heatregulating centres and so act in a more typical manner upon the temperature. Generally all these processes or several of them at least concur in bringing about the final result, namely, the process and symptoms of disease ; and for this reason we witness individual departures from the traditional diseasc-schema. 
The "specific" action of bacteria must therefore not be represented too simply and schematically. There is always involved the question of a reciprocal action, a struggle of the complicated bacterial cells with the complicated body-cells.

In general, we understand by the "specific" poisonous action of bacteria, the action of the poisons or toxins split off from proteids inside or outside the bacterial cell. The bacterial protoplasm is able, not only to form such "specific" poisons by the demolition of proteid compounds, but also to build them up out of simple substances such as ammonium lactate and asparagin. (Hueppe has shown that this is.true also for the pigment bacteria). The action of these poisons is therefore not the same as the general action of bacterial protoplasm, for the effect of the latter is due to its being foreign proteid. In the latter connection it has been shown that the poisonous effect of foreign proteids, even when it is exerted by bacteria, always consists in a lowering of the body temperature, while the "specific" poisonous effect consists sometimes in a heightening sometimes in a lowering of temperature, and in other cases expresses itself in other and various symptoms, such as paralysis, convulsions or necrosis, compared to which the 
influence upon temperature is of secondary importance.

Some ten or twelve years ago it was perfectly easy to describe and define disease-producing bacteria. In the state of our knowledge at that time it could be said, for example, that anthrax bacilli are microbes which always occur in typical situations in the organism affected by anthrax, and which on being transferred to another organism can again cause anthrax. To-day we know that only the first of these statements is even approximately correct. As regards the transfer to another organism, one might almost as well say that anthrax bacteria do not cause anthrax, a paradox which may be explained very simply. The virulence of the bacteria fluctuates greatly and it is this fact that renders dubious the issue of many inoculation experiments. I shall discuss these questions later, but it seems advisable to mention them now in order to emphasize the scientific inadequacy of the conventional schematic representations according to which specific bacteria are regarded as the "cause" of specific diseases.

In direct relation to the intoxications produced by poisons formed outside of the body and introduced into it, stand the septicæmic, pyæmic, phlegmonous and erysipelatous pro- 
cesses. If animals are injected intravenously, subcutaneously, or intraperitoneally with putrid fluids they die, but not always in consiquence of the poison introduced, for sometimes, especially at the beginning of the process of putrefaction, bacteria occur which are able to multiply in the body of the animal experimented upon. If this increase takes place in the blood it is called septicæmia; the visible changes do not go beyond bleeding or hæmorrhage. If, however, several metastatic localizations in the form of suppurations outside of the blood-vessels supervene, we speak of the affection as pyæmia. If the growth occurs in the skin we call it erysipelas, if subcutaneously, phlegmon. A sharp line of demarcation between these processes does not, however, exist and the same bacterial species evokes sometimes one, sometimes another process.

Anthrax (Fig. 24). The anthrax bacilli were first observed by Pollender in I849, and bý Davaine and Rayer in I850, and were accurately studied by Davaine and more especially by Koch, ${ }^{\mathrm{r}}$ who discovered also the spore-formation. The anthrax bacilli are nonmotile rods of $\mathrm{I} / \mathrm{r} \cdot 5^{\prime \prime}$ in breadth, and about $5^{\mu-10 \mu}$ in length; both the size and the shape

${ }^{1}$ Cohn, Beiträge z. Biol. d. Pflanz., II., 1876. 
1.
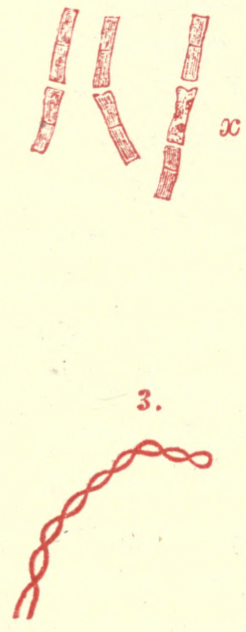

2.

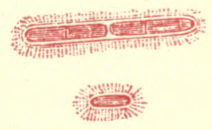

4.

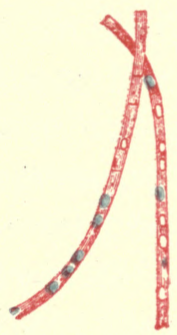

Fig. 24.-Anthrax bacteria.

I. From spleen pulp, (I. I200).

2. From the blood, showing possession of capsule, ( $\mathrm{I}: \mathrm{I000})$.

3. Edge of a culture showing filamentous windings of the so-called spirulina type, 1 I:300).

4. Spore formation, $(\mathrm{I} \cdot 500)$. 

of the rods vary with the conditions of nutrition. In the blood they occur isolated or in short threads; in culture fluids outside of the body, however, they proliferate into long matted filaments. Attenuated anthrax bacilli can also form long threads in the blood which resemble those of the bacillus of malignant œdema. The anthrax bacillus stains by Gram's method. In cultures it is not exacting; it thrives in gelatin, agar, and bouillon, and upon potato, and forms characteristic colonies of tangled threads. In bouillon it forms below the surface festoons of intertwined filaments. It grows between $\mathrm{I} 2^{\circ}-42^{\circ} \mathrm{C}$, and thrives best at blood temperature; above $42^{\circ}$, its growth is perceptibly interfered with. Endospores are formed between $18^{\circ}$ and $42^{\circ}$, but with the higher temperatures they are formed more quickly and abundantly. The organism is a typical bacillus. Free oxygen is necessary for spore-formation, hence this process can occur only outside of the animal body. Certain methods of staining show that in the blood the individual rods are usually not rounded at the ends, but are square-cornered or even swollen like joints of bamboo, while unstained rods from fresh cultures, and often also those from blood appear rounded; in the blood also capsules around the bacilli are often plainly visible. 
Cattle, the European races of sheep, goats, and horses as well as deer and roe are very susceptible to anthrax; the Algerian sheep resist infection. Dogs develop a generalized infection only after intravenous injection; with subcutaneous injection, abscesses arise ; young white rats are susceptible, older rats as a rule develop only local abscesses, but septicæmia may be produced by the injection of very large numbers of bacilli. Common frogs and treetoads are refractory toward anthrax at roomtemperature, but succumb if the temperature be raised; the tree-toads are the more resistant. Toads succumb at the room-temperature. Domestic fowls are resistant to anthrax, but can be made susceptible by chilling, and pigeons may be made susceptible by hunger.

Man is only relatively susceptible to the disease and a local disturbance in the form of a carbuncle always arises at the place of inoculation; when this is in the skin it takes the form of a "malignant pustule" ; in the intestine, that of an "intestinal mycosis." The carbuncle may heal, or a generalized infection or septicæmia may spread out from it.

Infection of the lungs with anthrax occurs in people who are engaged in the plucking and sorting of wool. This form of anthrax is 
called wool-sorters' or rag-pickers' disease. ${ }^{{ }^{1}}$ Infection of the skin may result from the bite of insects which have fed upon animals sick with anthrax and ingested the rods with the blood, or from the handling of hides to which spores cling. Anthrax of the lungs and intestine in the human subject is always to be referred to spore infection.

Buchner showed experimentally that the inhalation of spores led to a general anthrax infection without localization in the lungs, while inhalation of the bacilli produced an inflammation of the lungs. Cutaneous anthrax, which is strictly contagious, appears only sporadically, or is encountered only in individual cases during an epidemic. Spore infection in animals is always dependent upon the external conditions, for spores are formed only in those places in a pasture-ground which have been frequented by diseased animals, or where the dead bodies of infected animals have been interred. Stable epidemics are usually traced to the hay gathered from such localities.

What is sometimes regarded as the inheritance of the disease may be simply intra-uterine infection. A healthy placenta is not traversed by bacilli, but passage may occur if the blood-

1 In some cases of "rag-pickers' disease," however, not the anthrax bacillus but Proteus is concerned. 
vessels have been injured, as for instance by hæmorrhages. The placental tissue of rabbits has a greater tendency to hæmorrhage during anthrax than that of sheep, so that an intrauterine infection results frequently in the former animals, very rarely in the latter. Such hæmorrhages may occasionally arise through rupture of capillaries which have becomc choked with bacilli and hence be due to a mechanical cause, but as a rule they are to be referred to the effect of the toxin. Hankin, Brieger and C. Fränkel have prepared from cultures a poisonous albumose, but Marmier ${ }^{\text {I }}$ has lately disputed the proteid nature of the poison.

In the carbuncle that is found in cutaneous anthrax in the human subject there generally occurs a mixed infection. This may lead secondarily to other septicæmias or to pyæmia, and in this way it happens that people who are healed of the primary anthrax infection sometimes die notwithstanding.

Swine erysipelas and mouse septicamia. The bacteria found in these diseases are extraordinarily slender rods .I-.2\% thick and .8-I.O long. Endospore formation has not been positively observed, and whether or not the organism is a true bacillus is therefore still uncer-

1 Ann. de l'Inst. Pasteur, IX., p. 533. 


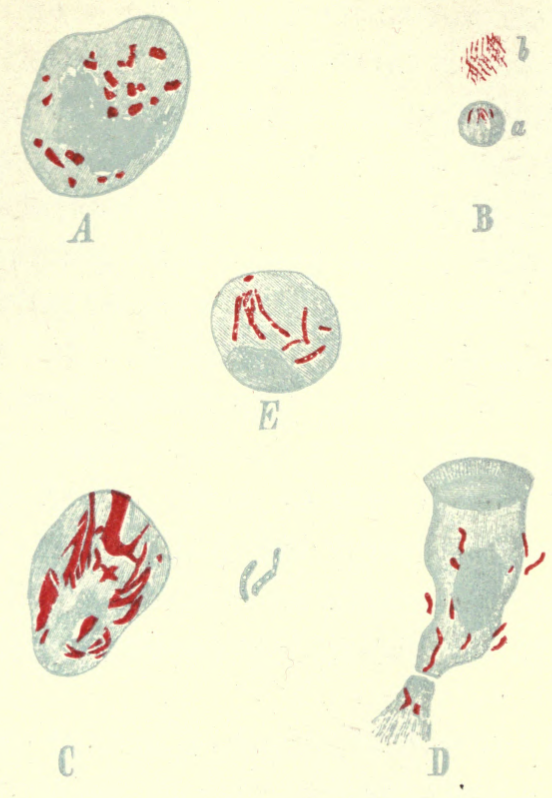

Fig. 25.-Bacteria enclosed in cells. In consequence of the method of preparation the cell-nuclei are somewhat altered. Bacteria stained red, body of cell blue.

$A$, Gonococci from pus, (I: IOoO).

$B$, Swine erysipelas (I:800); $a$, blood corpuscle containing rods; $b$, apparently free colony of rods, which, however, really occupies the site of a disinteg rated corpuscle.

$C$, So-called lepra cell. The cell is almost completely filled with bacteria, so that the nucleus cannot be made out, and the appearance seems to be that of free colonies of bacteria, (I: 1000). By the side of this are some free rods which in consequence of plasmolysis have the coccothrix form.

$D$, Intestinal epithelium with cholera bacteria (after van Ermenghem), 1:700.

$E$, Tubercle bacteria in a pus cell in sputum, (I: IO00). 
tain. In gelatin tube culture the growth along the line of inoculation takes the form of a brush, while single colonies appear almost like bone cells; the bacteria do not grow upon potato, and upon agar they do not grow so characteristically as in gelatin. They retain the stain when treated by Gram's method. In swine they evoke a simple cutaneous erysipelas which makes its appearance in the form of large patches; they may pass over secondarily into the blood, in the cells of which they are frequently enclosed (Fig. $25 \mathrm{~B}$ ), although they occur also in the free condition. Rabbits in like manner develop erysipelas at the place of infection and from that starting-point subsequently develop septicæmia. House mice and especially white mice are extremely susceptible, and sicken at the outset with septicæmia. The mouse is found after death sitting in a characteristic position with its back curved. Blooded swine are more susceptible than ordinary swine, while cattle, sheep, horses, carnivorous animals, guinea-pigs and especially field and wood mice are completely resistant. Virulent cultures become less virulent in their passage through rabbits, more virulent in their passage through pigeons. Natural infection of swine may take place by means of the food; the bacilli pass out of the body with the excre- 
ment. In putrefying fluids the bacilli generally lose their virulence in consequence of the competition of other microbes. Out of such putrid fluids Koch isolated the bacterium in 18.78 and regarded it as the germ producing mouse septicæmia, while Löffler in r882 obtained cultures from swine.

Hamorrhagic scpticamia. I have grouped under this name diseases caused by germs which, at their first discovery, were regarded as distinct species. Here belong the germs causing septicæmia in rabbits (Koch), which bear the same relation to the germs found in the larger domestic animals as do the germs of mouse septicæmia to those of swine erysipelas. Here also are to be placed chicken cholera (Perroncito and Pasteur), the Wildseiche and Rinderseuche of Bollinger, Kitt and Hueppe, and the German Schweineseuche described by Löffler.

The germs occur in the form of spheroids and of both short and long rods, in which polar granules usually arise by plasmolysis during the process of staining; they are arthrosporous bacteria, are non-motile, and are decolorized by Gram's method. The growth in gelatin and upon agar and potato is not very characteristic. In peptone solutions the bacteria form phenol and indol. Inoculated into the larger animals, 
DESCRIPTIONS OF PATHOGENIC BACTERIA. I63

the bacteria produce phlegmonous erysipelatous processes in the skin and pneumonitic processes in the lungs, but in the intestine marked changes are very seldom brought about. Spreading from the place of inoculation a general infection in the form of septicæmia results. If fowls are fed with pure cultures an enteritis is set up, and if the animals be injected intramuscularly a coagulation necrosis of the muscular tissue is caused; a general infection often concludes both processes. In slightly susceptible animals only local abscesses and necroses occur. If the bacillus is in a condition adapted for growth in the body of mammals it is relatively more virulent towards them than towards fowls; if it is adapted for an existence in birds the reverse is true. Because of the discovery of these two extremes it has been thought that two varieties exist, mammalian septicæmia and avian septicæmia, which however, pass over into one another. Such fluctuations in virulence in a state of nature have given rise to variations in the statements of authors regarding these diseases.' The fact that epidemics are more often observed among swine than among cattle is due to the differences in stabling and feeding, swine being more exposed to danger than the latter. Where wild swine 
are in the open along with other wild animals, all the susceptible species sicken. ('These epidemics of wild animals were all at one time regarded as anthrax). The disease may be contracted by cattle, domestic swine, wild swine, horses, deer, fallow deer, red deer, rabbits, and guinea-pigs, - to which the foregoing statement concerning virulence is especially applicable,and by mice; also by fowls, pigeons, and geese. What has been stated concerning the virulence of the disease for mammals holds good of birds as well. This disease is also closely related to the Büffelseuche of Italy, the germ of which, however, although forming indol, does not form phenol.

Of a different species, though similar both in form and culture, is the germ causing Schweinepest, first correctly identified by Selander. These bacteria are actively motile and, according to investigations by Hueppe, Caneva and Bunzl-Federn, they gelatinize milk with formation of alkali. The bacteria of hæmorrhagic septicæmia, on the other hand, coagulate milk with production of acid, so that by this test a simple and sure differential diagnosis is possible. The American swine disease or hog cholera (Salmon) and the swine plague (Billings) are identical with this disease. ${ }^{\mathrm{I}}$ Whether

1 Some confusion exists here. See "Additional Investigations 
the German Schweineseuche also exists in America is still somewhat doubtful; in Germany the Scandinavian-American swine-plague has been observed, at least sporadically. The disease manifests itself especially as a severe affection of the intestine.

A third and related group of germs discovered by Reitsch and Joubert, are morphologically similar, but the bacteria are actively motile, coagulate milk with production of acid, and form both indol and phenol in peptone solutions. The disease they cause was observed in Southern France among swine introduced from Algeria. Eberth found similar organisms in cases of ferret disease and spontaneous rabbit septicæmia. The difference between this and the first group lies in the motility of the bacteria, and in the fact that the swine suffer more from enteritis, as in the Schweinepest.

Two years ago a disease of swine was rife in North Germany, the chief symptom of which was a diphtheritic affection of the large intestine. According to Deupser, motile bacteria were always present. Unfortunately the exconcerning Infective Swine Diseases" by Theobald Smith and V. A. Moore, U. S. Dept. of Agriculture, Bureau of Animal Industry, Bull. No. 6. Selander appears to have worked with the bacillus of swine-plague and not that of hog-cholera. See for a very recent discussion of the nomenclature and etiology of these diseases, Preiss, Zeitschr. f. Thiermedicin N. F. II., 1898, p. r. E. O. J. 
tremely simple differential diagnosis between the Schweinepest and the French-Algerian Schweineseuche was not made.

These various affections of swine illustrate in a striking maniner the importance of bacteriology as a means of diagnosis of disease. The German Schweineseuche probably has its true home in the Alps so that its epidemic extension in the year I895 to Hungary and Servia is not remarkable, since sporadic cases have occurred there for years, although probably confounded previously with anthrax or with swine-erysipelas. The first case in Bohemia was observed by Hueppe in the summer of $\mathrm{I} 895$.

The Pyogenic Bacteria are, strictly speaking, the staphylococci, which received this name from Ogston because the cocci in the tissues are often disposed in grapelike clusters. In cultures they appear as micrococci which form yellow, orange or white pigment and are consequently distinguished as Staphylococcus pyo. genes aureus, citreus or albus, respectively. They liquefy gelatin and coagulate milk; they stain by Gram's method. Introduced subcutaneously into the body of animals in small tubes they exert a positively chemotropic effect upon the white blood-corpuscles, i.e., they attract them. Inoculated directly intu ani- 
mals they produce, according to their virulence, local suppuration, pyæmia or septicæmia. In man they have been observed in abscesses and in inflammation of the bonemarrow. The ability to induce suppuration is, however, by no means limited to these microbes. If cells of the body are destroyed mechanically, or by poisons, the necrotic tissue thus formed attracts the white blood-corpuscles. These corpuscles are adapted to the task of keeping free the circulatory channels and at the same time they assist in the utilization of the material fitted for resorption into the body. Hence the wandering-out of the white bloodcorpuscles from the blood-vessels into the tissues seems to be an important act of nutrition. When, however, white blood corpuscles which have been thus attracted come into the region of bacterial poisons they are paralyzed by the poisons, prevented from wandering back, and become local pus-corpuscles. It is now known, that, besides the pyogenic bacteria, other bacteria also can bring about pus formation, and the same thing is true as well of bacterial poisons and of other poisons such as corrosive sublimate.

In cases of severe suppuration the so-called Streptococcus pyogenes or erysipelatos is the one most commonly found. It is a coccus form 
arranged in chains; and stains by Gram's method. According to its virulence the Streptococcus produces simple or bullate erysipelas of the skin, suppuration of various organs, and also acute lung inflammations of an erysipelatous and spreading character, and acute puerperal fever. The same Streptococcus produces also acute anginas with diphtheritic incrustations, and the diphtheria-like affection which attacks a patient recovering from scarlet fever. The streptococci found in the so-called frambœsia, a skin disease of the tropics, are certainly not the cause of the disease, and are probably only erysipelas cocci that have penetrated the skin at the injured places.

In association with the process of caries or decay of the teeth are found all possible kinds of pyogenic germs. According to Miller the enamel of the teeth is first attacked by acids which are formed in the mouth as the result of bacterial decompositions and then the pyogenic bacteria in the mouth penetrate into the decalcified organic substance of the tooth. If cavities are created in this way then it is possible that other microbes, as for example those of tuberculosis and actinomycosis, may enter the body by way of the decayed teeth.

If we consider the great fluctuations in virulence shown by the pyogenic staphylococci 
and streptococci and, on the other side, the great differences in the susceptibility of man, we can well understand how these widely spread bacteria may produce suppuration of the internal organs or multiple external abscesses in one person, in another angina or catarrh of the mucous membranc, and in still another rheumatic processes. It may be, moreover, that these organisms are etiologically concerned in those obscure pathological processes referred to "catching cold" and which we can hardly speak of as specific diseases. Bacteria of this sort which live in or upon sound individuals without harming them may be called "œco-parasites." If any weakening of the tissues be brought about by privation, or any seat of disease be created by sudden injury such as burning or freezing, these ubiquitous bacteria take advantage of such a local predisposition to display their pernicious activity.

Wherever a predisposition exists on the part of the tissues, we find a number of microbes that can call forth inflammation and suppuration. In inflammations of the valves of the heart there are found under various circumstances, staphylococci, streptococci, or gonococci, and typhoid, pneumonia or tubercle bacteria. The same thing is true in certain 
inflammations of the joints and serous membranes.

If the tissues have become altered by other diseases, such as tuberculosis or scarlet fever, staphylococci or streptococci may insinuate themselves secondarily and produce secondary. diseases or mixed infections ; thus after scarlet fever there are often found diphtheritic incrustations accompanied by the presence of streptococci upon the mucous membrane. The destruction of lung tissue that takes place in tuberculosis is brought about by the suppuration induced by staphylococci and streptococci. Koch and Gaffky also found in one such case Micrococcus tetragenus, a coccus grouped tablet-form in blocks of four and surrounded with a capsule; it is perhaps a phase in the lifecycle of a sarcina, and should therefore more correctly be called Merista or Sarcina septica. It stains by Gram's method. Its growth upon our ordinary culture media presents no striking peculiarity. It does not liquefy gelatin. On inoculation, white mice and guinea-pigs succumb with a sort of septicæmia, while gray mice and field mice appear to be immune.

Pneumonia.-Pasteur first cultivated from ordinary sputum, and Talamon from pneumonitic sputum, a septic bacterium which A. Fränkel proved to be the cause of true fibrous pneu- 
monia in man. These bacteria are often lanceshaped, and are frequently grouped in pairs, for which reasons the organism has been given the name Diplococcus lanceolatus. They are arthrobacteria and stain by Gram's method. They are so sensitive to drying that a few days' desiccation is sufficient to render them powerless. When shut off from access of air, as in egg-cultures, they retain their virulence for many weeks and even for months, and their vitality for many months (Bunzl-Federn). They cause a simple typical septicæmia in rabbits and, when virulent, in white mice and guinea-pigs also, but for the latter animals large quantities are usually necessary. Dogs succumb to injection with the toxin but not to infection. In man the pneumococci induce typical fibrous pneumonia, which at times passes over into septicæmia; they are found besides in inflammations of the serous membranes, of the pleura, of the cerebral membranes, and in inflammations of the middle ear. They are found also living as œco-parasites in healthy persons, so that " catching cold" often affords them an opportunity of invading the body. In this fact lies the explanation of those familiar instances in which a healthy person suddenly develops pneumonia as a consequence of taking cold. 
In atypical cases of lung-inflammation, erysipelas streptococci have sometimes been found. Friedländer found also an arthrosporous bacterium which develops capsules, and in which both coccus and rod forms occur. This species is called Bacterium capsulatum pneumonice (Fig. 4, D.); it loses the stain in Gram's method. Upon gelatin it shows a nail-shaped growth and the gelatin near the surface is colored brown ; in contrast to the Diplococcus lanceolatus it is rather hardy. It causes septicæmia easily in mice and guinea-pigs, and also in rabbits upon the injection of large quantities.

It is seen by the statements already made that capsules are formed occasionally by a number of bacteria, as for instance by the anthrax bacteria. Capsule formation also takes place regularly in certain species of bacteria which in consequence have been denominated " capsule bacteria." The type is Friedländer's pneumo-bacillus. Identical with this organism, and differing from it only through variations in virulence, is the bacterium of rhinoscleroma, first seen by Fritsch in nasal tumors, and first cultivated by R. Paltauf and Eiselsberg. A bacillus called $B$. crassus sputigenus was also cultivated by Kreibohm from human sputum. This organism proved virulent for 
mice and rabbits ; it stained by Gram's method. Another capsule bacillus has been cultivated by Weichselbaum from a case of endocarditis with purulent infarction, one by Mandry out of bronchial mucus, and another by Kockel from suppurated hepatic cysts and meningitis. Fasching cultivated a capsule bacillus from the purulent mucous membrane of the nasopharyngeal space, and Abel one from ozæna. All of these reports of the discovery of capsule bacilli are not as complete as they should be, but $\mathrm{R}$. Pfeiffer succeeded in cultivating from the peritoneal exudate of a guinea-pig a capsulated species which actually invested the blood and tissue juices of the animal under experiment with a ropy quality. Chiari, in a case of cystitis in man, which led to suppurating inflammation of the kidneys, and from that to pyæmia, found a capsulated bacterium, generally occurring in rod-form; it stains by Gram's method. This bacterium is fatal to white mice, and causes pyæmia on subcutaneous and intraperitoneal inoculation : guinea-pigs, inoculated subcutaneously, develop extensive suppuration; and, when the inoculation is intraperitoneal, peritonitis and general infection result ; rabbits, inoculated subcutaneously develop suppuration, when inoculated intravenously, septicæmia and when the kidneys are in- 
jected, suppurating nephritis with ensuing septicæmia occurs.

Inflammation of the membranes of the brain can be produced by various bacteria, such as Fränkel's pneumococcus, the streptococcus of erysipelas, tubercle bacilli and $B$. coli communis. However, Weichselbaum and later, H. Jäger, have made it appear probable that the epidemic form of cerebro-spinal meningitis is caused by a particular species, the Diplococcus intracellularis. These bacteria stain by Gram's method, both in cultures and in preparations from the tissues, but in sections become decolorized; they form capsules, and are cultivated more easily than the lancet bacteria. White mice proved refractory to inoculation. The experiments with the organism are not yet complete enough to be altogether convincing.

The bacteria of infuenza were discovered by R. Pfeiffer in I89i. They are even somewhat smaller than the bacilli of mouse septicæmia, about two to three times as long as they are thick, without capsules, and are decolorized by Gram's method. 'They grow in the form of very fine glassy drops, and succeed best upon bloodserum or blood-agar or when hæmoglobin is added to the medium. A similar bacillus, which can be cultivated more easily and is called the 



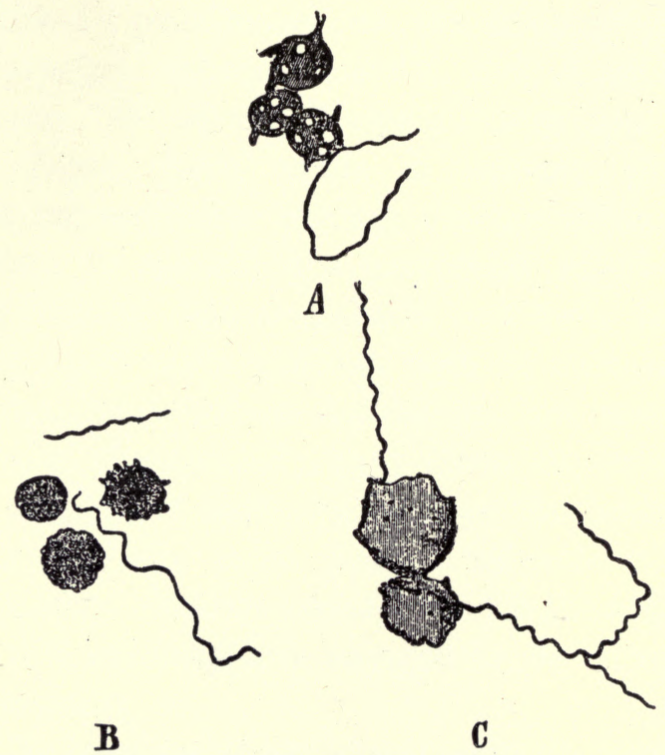

Fig. 26. $-A$, cholera bacteria in the blood of guirea pigs after infection of the small intestine. (From photograph by van Ermenghem) I : 700 .

$B$, and $C$, The Spirochæete of relapsing fever (after photographs), $B, \mathrm{I}: 700 ; C, \mathrm{I}: 1000$. 
pseudo-influenza bacillus, is perhaps only a variety of the influenza germ which has become saprophytic and so impotent. Among the lower animals only the ape has proved susceptible to inoculation with this germ, although rabbits may be infected with large numbers of the bacteria and develop fever and paralysis. Besides la grippe, the influenza organism causes in man atypical lung inflammations, hæmorrhages, and especially paralysis and persistent muscular weakness.

A true septicæmia is caused by the spirochæte of relapsing fever discovered by Obermeier in r873. The germ is more delicate in structure than the cholera bacteria, and up to the present time is known only in the form of long spirals, and not in the S or comma form (See Fig. 26, B, C, opposite). Moczutkowski has successfully infected healthy men with blood containing the spirochæte and Carter and Koch have done the same with apes, thus establishing the etiological significance of this germ. Attempts to cultivate the spirochæte have not yet succeeded. The germs fail to retain the stain in Gram's method. According to Metschnikoff the bacteria are enveloped during the fever-free periods and in great part destroyed by the cells of the 
spleen which function as huge devouring cells or " macrophages."

The existence of animal parasites, especially Tania and Gregarinida, in fishes has been known for some time; vegetable parasites, such as Saprolegnia, have also been known; and likewise the fact that some of the internal organs of fish, particularly the sexual organs, are poisonous. Mosso discovered that the blood of the eel is poisonous, and the poisonous quality of putrid fish has also been ascertained. Fischel and Enoch found in I89r, while working in my laboratory, that fishes, too, can succumb to bacterial infection. They discovered that a disease affecting carp is a sort of septicæmia accompanied by numerous hæmorrhages. The accompanying bacteria were endosporous, grew upon gelatin, agar, blood-serum, potato, and rice, and stained by Gram's method. It was then established for the first time that these bacteria form the same proteid-like poison while growing as parasites in the animal body, which they produce saprophytically in cultures. The bacteria and spores, freed from poison, infected carp, mice and guinea-pigs, and the animals all perished from septicæmia. The poison itself was also injurious to dogs, which sickened with diarrhœa in the same fashion observed in the "carp cholera." Emmerich and Weibel 
have observed in trout also a kind of septicæmia caused by bacteria,

The germs causing gonorrhoea and blennorrhoea were discovered with the aid of the microscope by Neisser. They were cultivated by Bumm upon human blood-serum and later were studied in a more thorough-going fashion by Wertheim especially by the aid of the bloodserum plate method devised by Hueppe; they grow only at blood temperature. According to Eraud and Hugounenq they secrete a poisonous proteid-like substance when grown in peptone solution, but not when in asparagin solution. The germs are biscuit-shaped; they give up the stain when treated by Gram's method; both these characteristics serve generally to distinguish them positively from the Staphylococci. They are usually enclosed in the gonorrhœal pus cells (Fig.25A), but occuralso in the neighboring organs, and are found in cases of peritonitis, ovarian inflammations, in the joints in gonorrhœal rheumatism, and in inflammatory conditions of the valves of the heart.

Nicolaier in I885 discovered in the pus formed in cases of lockjaw or tetanus rodlets which form endospores at one end. The end of the rod containing the endospores is broadened and swollen, giving to the germ the shape of a drumstick. Here, therefore, we meet with 
a representative of the genus Plectridium. In the vegetative stage the rods often elongate into filaments; they stain by Gram's method. In gelatin stab-cultures, delicate branches, like those of a fir-tree, grow out from the inoculation line into the gelatin; this appearance is less marked in agar. In glucose-bouillon, vigorous gas-production takes place accompanied by a pronounced turbidity which clears gradually, a deposit settling to the bottom. The gelatin is slowly liquefied by an enzymotic action. The bacteria are anaërobic and in cultures develop a repulsive odor. Growth can take place between $15^{\circ}-42^{\circ}$; spore formation can occur within the same temperature limits, but at the room temperature the rod-forms may persist for at least a week without forming spores. The vegetative cells grow poorly above $42^{\circ}$ and perish at $60^{\circ}$, while the spores are very resistant and withstand the action of both heat and chemicals.

Only cultures mixed with other organisms cause subcutaneous suppuration; the pure cultures are unable to do this. Perfectly pure cultures were first obtained by Kitasato through the application of a method based on the resistance of the spores to heat, and by Kitt through anaërobiotic methods. A powerful poison, in all likelihood of a proteid character, is formed in. 
the cultures. The bacteria are able to form this toxin synthetically in nutrient media free from proteid as well as by splitting up the proteids in albuminous media. The effect produced by the bacteria upon the animal organism is to be attributed to the action of the poison, since the effect runs parallel with the quantity of poison carried with or formed by the bacteria, and not with the number of bacteria themselves. The poison, like strychnine, acts upon the spinal cord and not upon the muscles or peripheral nerves. Mice, rabbits, sheep and horses are susceptible, fowls, dogs and men somewhat less so. Tetanus spores when alone do not usually germinate in the body, but they can germinate when introduced along with particles of soil or splinters of wood, or with pus. Accordingly infection in this disease is usually a mixed infection, and the tetanus bacillus is not to be regarded as a strict parasite. In the soil and in ooze it may perhaps participate in the marsh-gas fermentation.

These latter statements may also be true of the bacteria of malignant adema. These organisms were first described by Pasteur as the Vibrio septique, and were afterwards studied accurately by Koch. The motile rods have flagella on the ends and sides. The rods grow 
out into long filaments both in the animal body and in cultures; they are decolorized by Gram's method. During spore-formation the rods become spindle-shaped; the bacteria belong, therefore, to the genus Clostridium. They are anaërobic. In gelatin they grow with vigorous gas-production; the margin of the colonies is frayed out into fine rays, and the gelatin is gradually liquefied. In agar stabcultures also the colonies show branching. In bouillon, a turbidity makes its appearance followed by a deposit of sediment. The effect brought about in animals by subcutaneous inoculation is to be attributed not se much to the growth of the bacteria as to the formation of poison; only after the death of the host has occurred do the bacteria multiply very much, but then they multiply even in the blood, where a state of affairs similar to that in anthrax may sometimes be observed, although during life the blood is germ-free. Subcutaneous inoculation in guinea-pigs gives characteristic results: the animals become uneasy, draw themselves together in a heap and cry out at the slightest touch. Mice, rabbits, sheep, goats, horses, swine, dogs, fowls and ducks are also very susceptible. Man is moderately susceptible ; gangrenous emphysema is sometimes at least, caused by these bacteria. One 
instance is on record where two typhoid fever patients, who were infected with this organism in the course of a musk injection, perished from œdema. The bacteria of œdema are frequently found in the earth and in marshy soil.

The disease of cattle known as "quarterevil," "black-leg" or symptomatic anthrax, the bacillus of which develops subcutaneously with production of gas, is caused by bacteria which resemble those of malignant œdema in almost all points. Infection of animals is favored by the simultaneous introduction of lactic acid, probably because this substance brings about a necrosis of the cells. It is for a like reason, probably, that according to Roger, the natural immunity of rabbits to this disease can be overcome if the metabolic products of $B$. prodigiosus or of Staphylococcus be injected simultaneously with the bacillus of symptomatic anthrax. Cattle, sheep, goats and guinea-pigs are especially susceptible, horses, asses and white rats less so, while swine, dogs, rabbits, gray rats, ducks, pigeons, and fowls appear to be immune. Sometimes, for example in reciprocal protective inoculation, there appears to exist nothing but a difference in virulence between the bacteria of malignant œdema and those of symptomatic anthrax, but the question of actual 
identity must be regarded as still an open one. Symptomatic anthrax was formerly regarded as a form of anthrax till Feser and Bollinger determined its true specific nature in 1876 ; Arloing, Cornevin, and Thomas were the first to obtain cultures.

In diphtheria, rods were first observed microscopically by Klebs, and in 1884 Löffler succeeded in cultivating them on artificial media. The rods take stain badly and are easily plasmolyzed, so that usually the ends of the rods stain more plainly than the middle, or, sometimes, the staining of a number of granules gives a beaded appearance to the cell. The bacteria retain the stain when treated by Gram's method. The rods are localized in the diphtheritic patches upon mucou's membranes and are not dispersed through the body. The effect produced by their presence upon the animal organism is therefore due to the formation of poison. The poison was at first regarded by Roux and Yersin as an enzyme, and by Brieger and Fränkel as a toxalbumin; it is formed in media containing proteid and also in solutions devoid of proteid, as in ammonium lactate or asparagin (Uschinsky), and in proteid-free urine (Guinochet); and even after the formation of the toxin, no proteid reaction is obtained from these media; the proteid nature of 
the poison is consequently doubtful (cf. p. I23). Endospores have not been observed, and C. Fränkel has noticed occasional branched filaments. It is, then, evident that the position of the diphtheria germ in our system of classification is not clear; in any case, the germ is not a typical bacillus. Cultures develop between $18^{\circ}$ $-42^{\circ}$,-best in blood serum to which bouillon and sugar have been added, not so well upon glycerin agar. The colonies are white and usually remain distinct from one another; upon serum is formed a delicate white incrustation; in gelatin stab-cultures a scanty growth develops in the form of small white colonies. In broth, small grayish crumbs are formed which sink to the bottom ; rarely a diffuse clouding occurs; milk is coagulated by the growth of the bacteria. Guinea-pigs are especially sensitive to inoculation; somewhat less so are rabbits, young dogs, sheep, goats, horses, pigeons, and fowls. (The ordinary spontaneous diphtheria of fowls and pigeons is an altogether different disease). In the animals named above there arises, just as in man, a necrotic inflammation of the mucous membrane and, proceeding from this, an acute poisoning often accompanied by paralysis. The diphtheria bacteria have been found in man in the diphtheritic incrustation of the 
mucous membrane, in conjunctivitis fibrinosa, and (by Abel) in wound diphtheria. Virulent diphtheria bacteria have also been observed, existing as œco-parasites in healthy individuals; these may, under special condilions, induce self-infection or be the means of conveying the disease to susceptible persons, particularly to children.

Virulent diphtheria germs lose their virulence under cultivation, especially in agar cultures, while their growth becomes at the same time more luxuriant, that is to say, more saprophytic. Similar but non-virulent bacteria are sometimes found occurring spontaneously in man, Löffler being the first to discover this fact. Many bacteriologists, among them Roux, Yersin, C. Fränkel, and Hueppe, regard these so-called pseudo-diphtheria bacilli merely as true diphtheria germs which have become impotent and saprophytic, while Löffler, Hofmann, von Wellenhof and Escherich regard them as a totally distinct species. The pseudodiphtheria germs do not alter the reaction of alkaline bouillon while the diphtheria bacteria render it acid at the outset, but it afterwards becomes again alkaline.

Cholera asiatica. The so-called comma bacilli found in this disease were discovered by Koch in 1883 (Fig. 27). They occur in the form 

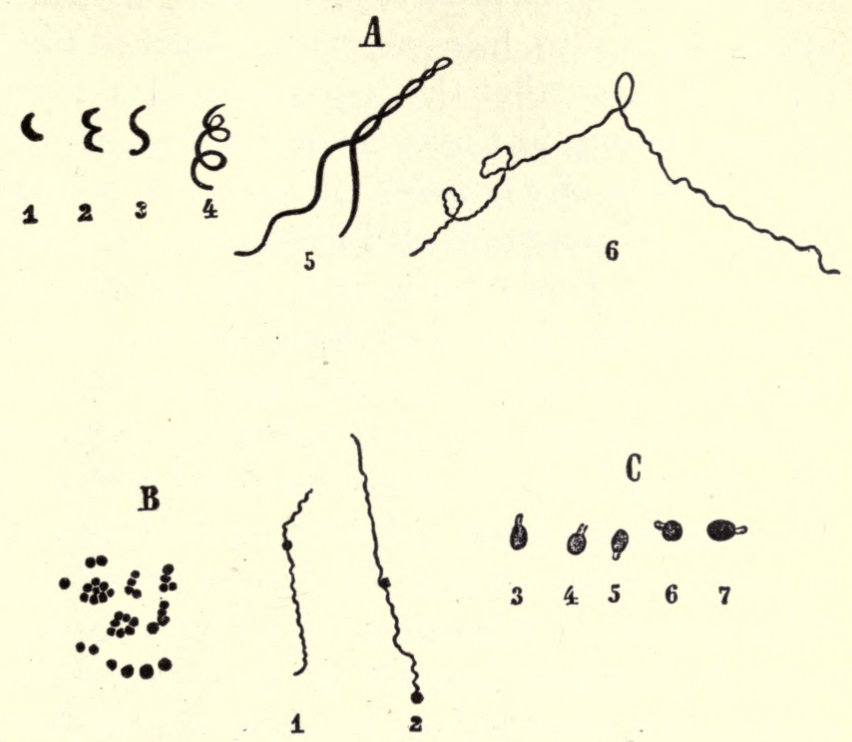

Fig. 27. Cholera asiatica.

$A$, Comma bacilli, I-4 after drawings ; 4 , twisted coil, so-called Spirodiscus, (about I : I200); 5, 6, spiral filaments with spirulina twistings (after photographs, about I : 700).

$B$. Ripe arthrospores (after photographs), about I : Iooo.

C. I and 2, Arthrospores in filaments (after van Ermenghem, from photograph), about $I: 700$.

3-7, germinating arthrospores (after photographs by Pertik, I : I200).

of rods curved like a comma and frequently bent far around like a crescent ; often, however, they appear perfectly straight. They grow out into $\mathrm{S}$ forms and long corkscrew filaments, the spirals of which are sometimes closely, sometimes loosely wound. Both the formation and germination of arthrospores have been observed. On our system of classification, then, 
they should be classed as Spirochate. Metschnikoff claims to have observed branched filaments also, so that the comma bacillus may perhaps belong in the cycle of development of some species of Cladothrix, a group in which all forms of comma bacilli have been actually observed by Zopf (cf. Fig. 5). The germs are decolorized by Gram's method. In the intestine they occur not only free, but also in the epithelium (Fig. 25D), and can even penetrate into the wall of the intestine itself as far as the muscular layer. Further penetration, however, ensues only in fatal cases, and then only immediately before death; the germs are as a rule, however, found in the gall-bladder; in animal experiments, both when inoculated into the peritoneal cavity or into the stomach, they may occasionally pass over into the blood, in which they sometimes appear like the Spirochate of relapsing fever (Fig. $26 \mathrm{~A}$ ). The effect produced in man depends less upon their proliferation in the intestine and in the intestinal epithelium than upon the formation of a toxin which, with concomitant lowering of the body temperature, proves fatal to men and susceptible animals. This proteid-like poison can be formed not only analytically but synthetically also, as for example out of ammonium lactate and asparagin. The toxin has been 
DESCRIPTIONS OF PATHOGENIC BACTERIA. I 87

obtained from cultures by Hueppe, Scholl and Petri. (Hueppe first obtained it from the bodies of cholera patients in I892, and Bosc likewise found the poison in I895 in the bodies of cholera patients.) R. Pfeiffer has attempted to identify the poisonous action of virulent comma bacilli with the effect of their cell proteid, and has accepted the theory of Cantani that it is not the living comma bacilli which through their formation of poison, are the effective agents, but rather the dead comma bacteria by virtue of the action of their poisonous body-substance. The cholera toxin is not, however, identical with the proteid of the bacterial cell; the effect due to the action of the latter substance is manifested also by various forms of impotent comma bacilli, but the toxin is formed only by the virulent variety.

The cholera bacteria grow in gelatin in the form of colonies which appear like fine fragments of glass or a tangle of glass threads; they liquefy the gelatin slowly. This initial character of their growth in gelatin is tolerably distinctive, yet many colonies grow rapidly, others more slowly. In consequence of such atypical growth, diagnosis is often quite difficult, and it is frequently necessary to postulate the existence of varieties of the species. Cultures obtained from an outbreak of cholera in 
Massowah especially are to be separated from cultures of cholera germs obtained in European epidemics.

In peptone solutions the bacteria produce indol and also reduce nitrate to nitrite; consequently on the addition of hydrochloric or sulphuric acid the nitroso-indol reaction takes place in the form of a rose-red coloration which has been named the "cholera-red" reaction. In ordinary bouillon a pellicle is formed on the surface, in glucose-bouillon this does not occur. On potato at high temperatures a yellowishbrown pigment is formed; in milk a rennetlike separation into curd and whey is sometimes produced. The differential diagnosis of cholera has become very difficult because many comma bacilli have been found which grow in gelatin and bouillon very much like the typical and atypical varieties of cholera bacteria.

In the lower animals, no spontaneous cases of any disease caused by Koch's cholera bacteria have ever been observed; when inoculated artificially, however, virulent germs prove infectious for guinea-pigs and often also for pigeons ; in the latter animals the toxic disease passes into a septicæmic. Another comma bacillus nearly related to Koch's, which was found by Gamaleia in a fowl epidemic and named after Metschnikoff, is infectious for animals ; pigeons 
DESCRIPTIONS OF PATHOGENIC BACTERIA. I 89

especially succumb easily. These bacilli give the cholera-red reaction and resemble Koch's bacteria in other respects as well.

The comma bacilli of Finkler-Prior do not afford the cholera-red reaction since, although they form indol, they do not reduce nitrates. Upon potato at the room temperature they develop a yellowish, slimy incrustation. The comma bacilli cultivated by Deneke from cheese likewise give no cholera-red reaction; they produce in milk a sulphur-yellow pigment. In the rivers Spree, Elbe and Seine, comma bacilli have been found which behave exactly like Koch's bacteria. These water bacteria, it is true, are phosphorescent, while the cholera bacteria are not generally so, but Rumpel ${ }^{\text {I }}$ has twice cultivated luminous comma bacilli from cases of cholera, and on the other hand, phosphorescent comma bacilli may lose their phosphorescence, although still remaining pathogenic. From a case of summer diarrhœa occurring in Bohemia, Zörkendörfer cultivated a species which was neither infectious nor gave the cholera-red reaction.

The virulence of the cholera bacteria varies extraordinarily and this fact has given rise to much controversy. Under saprophytic conditions of life, as in water, for instance, the germs

1 Berl. klin. Wochenschr.,_1895, No. 4 . 
lose their virulence, and this change comes about more quickly in pure water than in polluted water. Infection on the other hand is favored by a diseased condition of the mucous lining of the stomach, and Metschnikoff has discovered that the infection of animals can be accomplished more easily if other microbes are inoculated simultaneously with the cholera germ.

Intestinal alterations like those observed in cholera may also be broughtabout by the intravenous inoculation of putrid fluids, as Hemmer, Virchow, and many others noticed long ago. R. Fischel observed similar appearances in children, as a consequence of sepsis.

Cholera nostras. This disease is not to be attributed to a single bacterial species. The fact seems to be that several œco-parasites, under special conditions which serve to create a predisposition, become able to invade the body, multiply there and form poison. A case of this sort was communicated by me in 1887 : a person, after drinking very cold beer while irr a heated condition, became the subject of a violent cholera-like attack with typical ricewater stools, an effect that was brought about by the ordinary colon bacillus, $B$. coli communis. The same bacteria have been subsequently often found in summer diarrhœa, 
indeed, they were regarded by Emmerich as the cause of Asiatic cholera. Cases of cholera nostras in which the comma bacilli of FinklerPrior were found, have been recorded by Finkler-Prior, Lustig, Gruber, Ruete and Enoch. Zörkendörfer found in one case still a different kind of comma bacillus, and in another case Beck found streptococci.

Typhoid Fever. The bacteria of this disease were first demonstrated microscopically by Eberth and Koch, and in I884 were cultivated by Gaffky. They are short plump rods with rounded ends, often joined in filaments. They stain in sections less readily than many other bacteria, and in consequence of plasmolysis show granulation and polar granules. Endogenous spores are not found, so that the germs must be placed with the arthrobacteria. Gram's coloration is negative. They are actively motile and possess flagella on the ends and sides. The size of the rods varies very greatly and according to the media in which they are growing. They grow at the room and at blood temperatures and are not fastidious about their food-substance. Upon gelatin they form white, irregular, often leaf-shaped colonies which spread over the surface in a fine iridescent film. Upon certain potatoes they do not grow at all, upon some they form a delicate yellow 
brown coating. As a rule, however, they spread out upon the potato in the form of an invisible film the existence of which is made apparent to the observer only through the increased glistening of the surface. This growth on potato is usually characteristic, but unforiunately it is not constant and is observed occasionally in other species, so that differential diagnosis of the typhoid bacteria is at times very difficult. Many saprophytic species from water and soil grow, especially upon gelatin, very much in the manner of the typhoid bacillus and can ordinarily be distinguished from it only by such characters as individual form, behavior towards Gram's stain, motility, and growth upon potato.

It is often extraordinarily difficult to distinguish the typhoid bacillus from B. coli communis. Microscopically and culturally the difference is inconsiderable. The greatest pains have been taken to discover fundamental differences. As a rule $B$. coli forms a dirtyyellow incrustation upon a piece of a potato on which the typhoid bacillus grows in the form of an invisible film. $B$. coli generally coagulates milk and the typhoid bacillus does not; in glucose solutions vigorons gas-production is brought about by $B$. coli, but not by the typhoid bacillus ; $B$. coli forms indol out of 
peptone, while the typhoid bacillus does not, so that when potassium nitrite and sulphuric acid are added to both cultures a rose-red coloration appears in the culture of the former, and not in that of the latter. $B$. coli forms dextrorotatory, the typhoid bacillus lævo-rotatory lactic acid out of milk-sugar. The reduction of nitrates to ammonia is accomplished by both species. However, many of these statements are positively contradicted by some observers.

There are in fact at present two opposing views. The one which to me seems to be the better founded is that the bacteria of typhoid fever and $B$. coli communis are two distinct species. The other view is that the common intestinal saprophyte, $B$. coli communis, is an œco-parasite which, under special conditions, may become able to invade the body, and penetrate into the living organism where it undergoes transformation into the typhoid bacterium.

Both kinds of bacteria are usually not infectious for the lower animals, but as a rule merely toxic; only when the bacteria are very virulent does a multiplication take place in living rabbits and mice. The "true" typhoid bacteria produces typhoid fever in man, penetrating from the intestine into the Peyer's 
patches and thence into the mesenteric glands and the spleen. They are found in the rosespots on the abdomen, but the circulating blood is usually free from them. They may induce also broncho-pneumonia, meningitis, myocarditis, orchitis, and especially suppurations such as otitis, periostitis, peritonitis and empyema. They may also produce inflammation of the kidneys, and I have cultivated them from the urine during life in cases where albuminuria occurs, while A. Pfeiffer has cultivated them from the diarrhœal stools, where they generally appear only after the first week of the disease.

The "true" colon bacteria have been repeatedly observed in pneumonia in children and also in inflammatory processes in the intestine, especially in inflammation of the appendix and in perforation-peritonitis; also in otitis, puerperal fever, and more often, in inflammations of the bladder when inflammation ascending to the kidney may be induced.

The typhoid bacteria have been found in the water of wells, especially in the slime at the bottom, and once also they have been found in soil ; the colon bacteria are often found in polluted water.

In cases of meat-poisoning, bacteria are usually found which bear a striking resemblance 
to the colon bacillus. A. Gärtner ${ }^{\mathrm{I}}$ has isolated a species which has frequently been found in cases of poisoning from meat, sausage and milk. In cultures, however, after about two transfers, a difference in the behavior toward stains makes its appearance. The colon bacterium generally shows polar granules, but in Gärtner's bacterium, after staining with gentian-violet and decoloration with 2 per cent. acetic acid, the middle portion remains colored.

In the epidemic of bubonic plague occurring in China, in I894, bacteria were found by Yersin and Kitasato which occur in the form of cocci and short rodlets, and belong therefore to the genus Arthrobacterium. The characteristic growth of the microbes upon agar and gelatin has not been communicated up to this time. $^{2}$ In man they are found at first in the

I Correspondenz-Blatt d. allg. ärztl. Ver. von Thüringen, I888, No. 9 .

${ }^{2}$ There seems still to be some uncertainty respecting the identity of the germs originally described by Kitasato and Yersin. (Ogata, Centralbl. f. Bakt., XXI., I897, p. 769). The plague bacillus that has found its way to bacteriological laboratories and with which successful inoculation experiments have been made has well-defined characters. It is rod-shaped, and is about $\mathrm{I} \mu$ in diameter, though varying considerably in length and exhibiting marked pleomorphism. It is wholly without the power of independent movement. It stains easily with the ordinary aniline dyes, but is decolorized by Gram's method. Growth occurs readily on the ordinary nutrient media. On agar, white circular colonies, somewhat transparent and with iridescent edges, are formed. The germ multiplies best at about the temperature of the human body, though it also grows at $8^{\circ}-10^{\circ}$ 
buboes, thence they extend into the lymphatic glands and shortly before death are found in rare instances and in small numbers in the blood. Subcutaneous inoculation of rats, mice and rabbits, causes these animals to sicken with formation of buboes; the animals also succumb to stomach infection with virulent cultures taken directly from man. An epidemic among rats preceded the epidemic of the plague in that quarter of Hong Kong lately visited by the scourge ; buffalo and swine also sickened simultaneously. The question of the mode of transmission of the disease is still obscure; one well-supported possibility is that of the conveyance of contagion by flies.

"Mouse typhoid" is, according to Löffler," caused by an anaërobic, arthrosporous bacterium which grows slowly beneath the surface of gelatin. In the interior of the gelatin it de-

Spore formation has not been observed. Under favorable conditions of moisture, temperature, etc., the plague bacillus may survive for a long time outside of the animal body. (For a good description of the characters of this bacillus cf. Abel, Zur Kenntniss des Pestbacillus, Centralbl. f. Bakt., XXI., I897, p. 497, and the paper of Ogata cited above.)

Rats, mice, guinea-pigs and rabbits are susceptible and manifest symptoms closely resembling those of the bubonic plague in man. Animals such as rats are naturally infected and probably play an important part in the dissemination of infection. An anti-plague serum has been prepared by Yersin and Calmette, and has been used with distinct success in parts of China and India. E. O. J.

1 Centralbl. f. Bakt., XI., r892, p. 130. 
velops delicate white fleecy clouds which become diffused through the medium. In agar yellow-white colonies limited in extent, arise. The small rods are like needle-shaped crystals, O.8-I $\%$ long, O.I-O.2\% thick, and are often grouped in pairs; they are not motile. These bacteria are interesting from the fact that Löffler used them successfully in combating a plague of mice in Thessaly. The cultures were smeared upon bread which was distributed over the fields so the mice might feed upon it, the bacteria having proved to be harmless for all the animals experimented upon save mice.

Tuberculosis. Tumors in connective tissue may occur in the form of nodules or tubercles varying from the size of a millet seed and under to the size of a pigeon's egg. By the term tuberculosis, however, is understood a definite kind of nodule formation which shows, besides small cells, epithelioid cells (Fig. $25 \mathrm{E}$ ), and often giant cells, and is caused by an organism studied microscopically by Koch and Baumgarten in 1882 . The organism was also cultivated, and was more accurately and fully investigated by Koch (Fig. 28.). The rods are often plainly enclosed in a sheath, inside of which are found, along with the rous, whole series of cocci formed as the result of plasmo- 

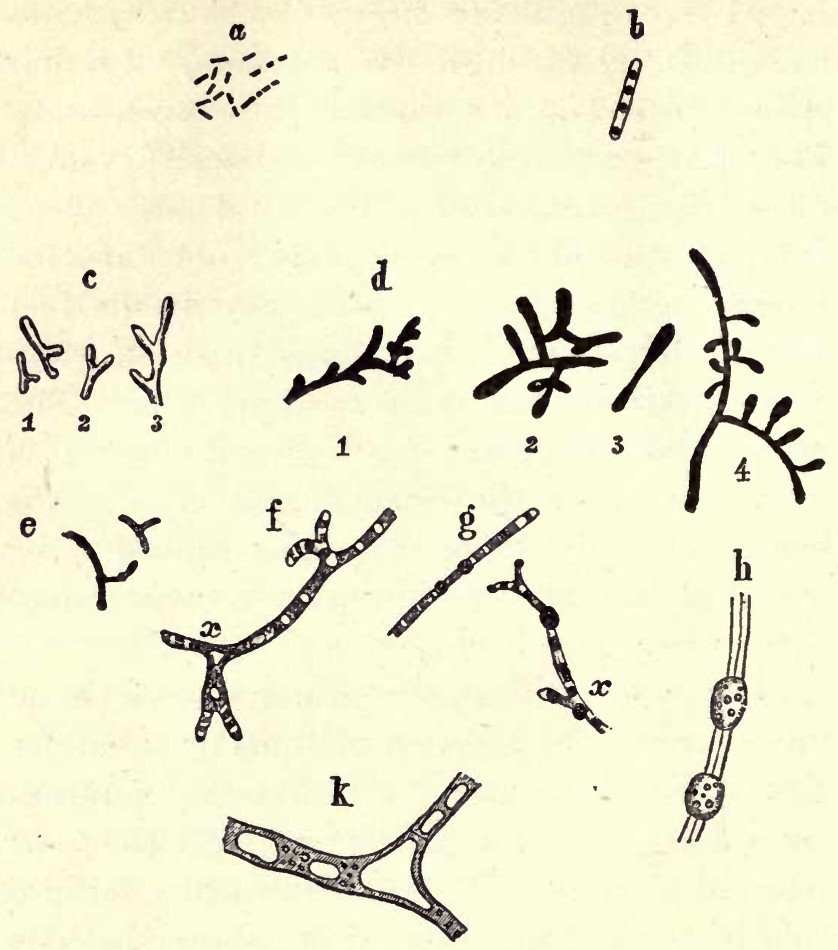

Fig. 28.-The Germ of Tuberculosis.

$a$, ordinary forms found in cultures and sputum (after photographs), about $\mathrm{I}: 900$.

$b$, Shows plasmolyzed cell contents, so-called coccothrix forms (I : 1250$)$.

$c$, portion of the edge of a fresh culture of the germ of mammalian tuberculosis, unstained (about $I: 2000$ ).

$d$, stained, I-3, after photographs by F, Fischel, I, the germ of avian tuberculosis from glycerin agar, 2, 3, the germ of mammalian tuberculosis from egg cultures; 4, mammalian cultures from glycerin agar, Hayo Bruns. (I-3, about I : I200 ; 4, I : I000) $e, g, h$, Formation of Chlamydospores ; $e$, mammalian tuberculosis (after photographs, I :9000) ; $g$, from sputum (drawing after Coppen Jones, I : I250); $h$ chlamydospores of Mucor for comparison. $f$, branching of filaments (after Coppen Jones), I : 1250 ; at $x$ it can be seen that the vacuoles extend from the' main stem into the side branches, as in $k$, a hypha of Penicillium thus showing the existence of "true" branching. 
lysis. The rods develop filaments which exhibit true branching; the branches often show club-shaped buds. There are no endospores as was at one time claimed, Koch having mistaken vacuoles for spores. On the other hand, according to Coppen-Jones chlamydospores are actually formed. The so-called tubercle bacillus is consequently not a bacillus at all, but the parasitic growth-form of a pleomorphic mould.

The cultures grow, although slowly, upon bouillon, blood serum, and agar, and thrive best when glycerine is added to these media. The bacteria when derived from man and other mammals generally grow more slowly than those obtained from the body of fowls. Growth is first apparent in the former after I4 days, in the latter after 8 days; the former develop dry scales, the latter a somewhat moister and smoother film; the former grow between $29^{\circ}-42^{\circ}$, the latter between $25^{\circ}-44^{\circ}$. Hueppe and Fischel, by varying the conditions of cultivation, have so modified the mammalian germ that it grew like the germ of fowl tuberculosis, and the latter like the germ of mammalian tuberculosis. The virulence also was influenced in such a way that mammals could be infected by the bacteria of fowl tuberculosis and vice versa. Consequently, the view of Maffucci and Koch 
that there are two different species or varieties of bacteria, one of which causes mammalian, the other avian tuberculosis, falls to the ground. The two kinds are simply nutritional modifications, the one being adapted to the mammalian organism, the other to the avian organism which is endowed with a somewhat higher temperature. Fischel cultivated from the body of an ape bacteria which were in no wise different from the bacteria of avian tuberculosis, and I have cultivated bacteria from fowl and pheasants which bore all the characteristic marks of the germ of mammalian tuberculosis.

In man the micro-organism is found in simple miliary tuberculosis; in tuberculosis of the skin and in lupus, in scrofula and tuberculosis of the joints ; when in the lungs in association with various pus-producing bacteria, it produces lung-consumption. The clinical conceptions phthisis and lupus therefore need to be further defined to accord with their etiology, i. e., we must distinguish tuberculous, carcinomatous, or syphilitic phthisis and tuberculous or carcinomatous lupus; the unqualified terms, phthisis and lupus always mean at present the respective forms caused by the tubercle bacillus. Experiments upon animals show that, besides simple tuberculosis, the bacteria induce also simple phthisis and suppuration. 
If tubercles occur in which, instead of the tubercle bacillus, other bacteria are found the affection is called pseudo-tuberculosis. Malassez and Vignal have observed an affection of this sort which is caused by cocci, A. Pfeiffer and Eberth one by rod-forms, Fischel one by filamentous bacteria and Eppinger one by a Cladothrix. Non-communicable tubercles may be produced also by the eggs of distomes and by other foreign bodies; even dead tubercle bacilli may, according to Prudden, cause tubercle formation.

Tuberculosis occurs spontaneously in apes as well as in man, and also in cattle. (In these animals the form of pleural tuberculosis with a tendency to calcification is called by the special name Perlsucht; the rods found here are somewhat smaller and more pointed.)

The disease occurs also in guinea-pigs and rabbits. Field-mice, when artificially inoculated, also sicken; among dogs only over-fed pet dogs, like pugs, are even relatively susceptible; goats seem to be immune. The disease may occur epidemically among fowls and pheasants.

Infection in man is for the most part extrauterine, yet placental intra-uterine infection does sometimes occur and may manifest itself only after birth, thus giving an appearance as 
if the tubercle bacteria themselves were inherited. As a matter of fact only the predisposition to tuberculosis is really inherited. A. Gärtner obtained eggs which contained tubercle bacteria only in the case of intra-abdominal experimental tuberculosis of female canaries. 'The infection of birds' eggs corresponds, however, to a placental infection in mammals and not to the infection of a mammalian egg. The conveyance of these bacteria into the ovum by means of the semen does not take place; but, in cases of tuberculosis of the male sexual organs an infection of the female sexual organs may result and a placental infection of the fœtus follow in its track.

In the outside world the bacteria are found, according to Cornet, only where.sputum has been deposited in great quantities, as in the sick-room, while in the open the sun soon destroys them, so that they have been found out of doors only once, and then (by Schnirer) in dust adhering to grapes.

In leprosy Armauer Hansen discovered rods which behave toward stains like the tubercle bacteria, but are somewhat more pointed in shape. They are found with special frequency in the skin, where they are enclosed in large cells (Fig. 25 C), which were earlier described by Virchow as lepra-cells. Attempts to cul- 
tivate the germ have not succeeded. Arning successfully infected a criminal condemned to death at Honolulu, and Melcher and Ortmann seem once to have obtained an infection in rabbits.

In syphilis, Lustgarten has, by staining, demonstrated special rod bacteria both in primary syphilitic manifestations and in the inherited disease. This is really the only fact that supports the view that these bacteria are the cause of syphilis. Bacteria occur in the secretion of the prepuce which, in consequence of being impregnated with fat, stain in a manner similar to Lustgarten's bacteria; the wax of the outer ear imparts to various bacteria a similar peculiarity of stain.

It is by no means easy to distinguish between the bacteria of tuberculosis, leprosy, syphilis and smegma by methods of staining. The tubercle bacilli, by virtue of a mucouslike substance occurring in the membrane (isolated by Weyl), possess a remarkable resistance to acids. Ehrlich was the first to make use of this property in differential staining. If these bacteria are stained red with a mordant stain, as with carbolic acid fuchsin or aniline water fuchsin, the stain resists subsequent treatment with strong mineral acids, while other bacteria as well as cell-nuclei are 
decolorized. The latter may then be given a contrast stain with a green or blue dye. With this treatment the red tubercle bacilli stand out in sharp relief against a green or blue background. The leprosy bacteria when once stained, behave in almost the same manner but, according to Baumgarten, they differ from the tubercle bacteria in staining quickly and well in a simple watery solution of fuchsin without mordant. The syphilis bacteria are easily decolorized by mineral acids, the smegma and earwax bacteria by alcohol.

Actinomycosis in man was referred by $\mathrm{B}$. Langenbeck as far back as I 845 to the growth of a mould, but was first accurately described by J. Israel in 1878 ; the microbes were obtained in pure culture by Bostroem, M. Wolff and J. Israel. Actinomycosis in cattle was recognized in 1877 by Bollinger, and the disease was communicated to calves by Ponfick. When bones, such as those of the jaw or the mastoid process, are attacked by the suppuration accompanying this disease there are found small, gritty, yellowish granules which consist of a central core of tangled filaments, from which club-shaped rays shoot out peripherally. The threads are often branched and have the character of true sheathed filaments inside of which both rod and coccus forms are found. 
The various forms of this germ that have been discovered up to the present time are almost the same as those found among tubercle bacteria. In cultures also the growth-forms often suggest those of the tubercle bacteria; perhaps these organisms belong to one and the same genus of moulds. The ray-fungus stains by Gram's method like the bacteria of tuberculosis and leprosy. In the beginning it grows best when the access of air is prevented, but soon adapts itself to aërobic conditions. Infection has succeeded with rabbits and guineapigs. ${ }^{I} \quad$ Natural infection, it is thought, may take place through introduction of the parasite into the body upon grains of various cereals, but I have not succeeded in demonstrating microscopically or culturally any one of the growth forms in a single case that has presented itself. Actinomycosis may spread from the jaw to the internal organs, lungs, liver, heart and brain; perhaps the skin also may be primarily affected. Hofmann von Wellenhof and Gruber found a bacteria-like organism living under saprophytic conditions which

1 The actinomyces fungus discovered by Duncker in swine is different from that occurring in cattle and from that found in human actinomycosis. The microscopic forms of the cattle actinomyces of Germany differ from those shown by an actinomyces from Tasmania and the mainland of Australia, sent me by Archibald Park in 1891 . 
behaved itself in experiments upon animals very like the actinomyces fungus.

In glanders, Löffler and Schütz discovered in I882 minute rods which do not form endospores and are joined to one another in short threads; according to Semmer branching is occasionally shown; the rods do not stain by Gram's method, and in sections can often be perceived only with considerable difficulty. They grow only at a temperature above $22^{\circ}$, and form moist, shiny white layers upon agar and blood serum; upon potato they develop yellow incrustations, later becoming brown; virulence is very soon lost. The freshly cultivated bacteria are very virulent and the disease is extremely contagious, so much so, that already two bacteriologists; Protopopoff and Hofmann von Wellenhof, have lost their lives through accidental self-inoculation.

Men, horses, mules and asses are especially susceptible to this germ, next stand goats and cats, sheep and dogs are more resistant, and swine still more; neat cattle are immune. Guinea-pigs and field and wood mice succumb readily to experimental inoculation; house mice and white mice, on the other hand, are immune. According to Leo, however, white mice succumb if they are made artificially diabetic by feeding with phloridzin. Among 
birds, only pigeons are susceptible. Experimental glanders in the guinea-pig takes the form of an acute miliary tuberculosis which leads to death in a few days.

The existence of parasites in affections such as the granulation tumors has not been proved up to this time; especially is this true of carcinoma and sarcoma. It may, however, be mentioned that the Perlsucht form of tuberculosis was formerly considered, on the ground of microscopic observations, as lympho-sarcoma, and rhinoscleroma was thought to be a kind of sarcoma. Another form of tumor which develops in the spermatic chord of the horse and was regarded on histological grounds as sarcoma was attributed by Rivolta and Johne to the invasion of bacteria, the germ being an ascococcus or coccus arranged in rounded zoöglœal masses.

It is important to bear in mind that bacteria. are not the only organisms that can provoke fermentation and disease. We need only recall, in fact, the familiar case of the alcoholic fermentation which is produced by the socalled yeast plant. These yeasts really belong to the group of moulds, whether we take Hansen's view that they should be placed in the ascospore-forming genus Saccharomyces, or regard them with Brefeld, Juhler and Jörgensen 
as developmental forms of different genera and species of moulds. It was demonstrated some time ago by Lewis that flagellates or ciliabearing monads were sometimes found in the blood of rats and, according to Gaule, Rättig and others, members of this group are found also in the blood of frogs. There undoubtedly exist, therefore, microbes belonging to the animal kingdom which are capable of inducing fatal septicæmia. Von Wittich and Koch found septicæmic monads of a like kind in the blood of German marmots.

Loesch as far back as I87 I, and subsequently Koch, Kartulis and others demonstrated the presence of amœbæ in the human intestine in cases of dysentery and also in the liver-abscesses not infrequently accompanying this disease. These amœbæ belong perhaps to the group of protozoa. The successful communication of the disease to cats and dogs by inoculation with the amœbæ makes it seem probable that the amœbæ are the cause of the disease. In the intestinal ulcers there are always found bacteria as we1l, rod-forms especially, probably the results of secondary infection; in the liver-abscesses, streptococci and staphylococci are at times to be observed along with the amœbæ. Organisms of a similar kind, which, to be sure, were placed by Woronin among the Myxomycetes or slime- 
fungi, occur in a remarkable plant disease, the "finger and toe disease" of cabbages ; Woronin called this myxamœba, Plasmodiophora brassica.

In some diseases of plants, bacteria may appear as the exciting cause, but as a rule the acid reaction of plant tissue hinders bacterial growth. The wet-rot of potato is caused, according to Reinke and Berthold, by an endosporous bacillus which penetrates the interior when the cork layer is injured. According to Wakker, the "yellow" disease of hyacinths in Holland is due to bacteria which occur in yellow slimy masses in the vessels of the bulb and in the vessels and parenchyma of the leaves. Ad. Mayer considered the mosaic disease of tobacco leaves to be due to bacteria, and Arthur attributed a widely-spread disease of the pear-tree in America to a species named M. amylovorus. ${ }^{\mathrm{I}}$

Among men and domestic animals there are some diseases caused by microbes belonging to the group of animals, known as Protozoa; the taxonomic position of these organisms is still in controversy, however. The disease known as surra, a severe and often fatal

1 An excellent summary of the present state of our knowledge regarding bacterial diseases of plants is given by Erwin F. Smith, in the American Naturalist, Aug. 1896, pp. 626 et. seq.-E. O. J. 
septicæmia occurring in India among horses, asses, and camels, is caused by flagellate monads (Crookshank.)

In I882, Laveran proved that animal microbes were present in the blood of patients suffering with malaria; this microbe was called Plasmodium malana by Marchiafava and Celli. Gerhardt has been able to cause malaria in healthy men by transfusion of blood containing these minute orgarisms, which are certainly to be regarded as the exciting cause of the disease. Attempts at cultivation have not succeeded up to the present time, so that the course of individual development must be inferred from inspection of the different forms in various stages of development.

In the smallest disk-shaped forms,-which, however, can change their shape in an amœboid fashion,-the nucleus is large in proportion to the cytoplasm; in the older individuals the case is reversed; the plasm of the young forms is homogenous, that of the older ones often granular. In the older forms there is always found the black malarial pigment which is called melanin and is supposed to be the digested and altered hæmoglobin. The fully formed parasites develop flagella which often break loose from the cell; frequently the flagella show knob-shaped swellings usually 
at the end. Some parasites occur in the form of crescents which, in blood removed from the blood vessels, are slowly altered to spindleshaped, oval, and finally spherical structures; $i t$ is still uncertain whether this transformation takes place also in the circulating blood. While the spores are being formed, the pigment gathers at the centre. The protoplasm then falls apart by radial striations into a rosetteshaped figure; the peripheral portions of this become the spores, the central heap of pigment remaining behind. The spores arise, therefore, by a kind of segmentation of the cellcontents. The unpigmented spore remains free in the blood for some time, then attaches itself to a red blood-corpuscle which it penetrates and then proceeds to nourish itself at the expense of the hæmoglobin of the corpuscle. The crescents, according to Laveran, are the encysted form of the parasite; according to Mannaberg, however, they are a conjugation-body or syzygy, that is to say, an incomplete fusion of two parasites ; on this interpretation, conjugation would be a preparation for sporulation.

Two views prevail as to the relation of these forms to the different kinds of malarial fever. Golgi assumes the existence of three varieties of the parasite (namely, a quartan, a tertian, 
and a quotidian parasite), each one of which produces different forms of the fever in accordance with the peculiarities of its development. Marchiafava would add to these yet a fourth, the malignant tertian parasite. This belief in the existence of several parasites corresponds to the usage of physicians and has therefore found wide acceptance. But it must still be considered as an open question whether the evidence for the existence of these varieties is altogether conclusive. Such progress as has been made in bacteriology should incline us to use great caution about accepting any attempt at schematic division. Laveran in fact still maintains the other view; according to him there is only one pleomorphic parasite and the different kinds of fever are due not to different varieties or species of the parasite but to the varying dispositions of men. This view has the great merit of being more in harmony with the progress of micro-parasitology.

Since it has been shown that the so-called tubercle bacilli are parasitic growth-forms of a mould, I may, in conclusion, add some remarks upon the diseases of men and animals due to moulds. The true moulds are aërobic and capable of forming spores only with access of air, while the mycelium and the torula forms are able to develop when air 
is shut off. We usually find moulds therefore, parasitic only upon the surface of the body,-upon the skin or the mucous membranes. The favus mould was identified by Schönlein as far back as I839 as the cause of scald, and was named in honor of its discoverer Achorion Schönleinii; the different kinds of favus occurring in man may be only varieties of one species. The very similar Trichophyton tonsurans, which was found in I 845 by Gruby and Malmsten, is certainly another species. The cause of the disease pityriasis versicolor was discovered by Eichstedt in 1846 to be the Microsporon furfur.

The disease known as thrush, an affection of the mucous membrane, is caused by Oidium albicans; it occurs often among children, especially upon the mucous membrane of the mouth, while in adults it can develop only in specially weakened conditions such as those brought about by typhoid fever or phthisis. The torula form may also grow and germinate in the interior of the body. When rabbits are inoculated intravenously, a general mycosis of the internal organs is brought about. In man, a case is recorded by Wagner in which the oidium made its way into an injured vein and from there into the brain, where it gave rise to a fatal mycosis. 
The true moulds have been observed growing spontaneously upon the cornea, in the passage of the outer ear, upon the mucous membrane of the larynx and in the lungs; in these places they can also form spores. The internal organs to which the germs must be conveyed by means of the blood vessels are rarely affected by moulds, since the moulds as a rule grow only superficially. On the other hand it is easy to cause infection of the internal organs of the lower animals with moulds by injecting spores into their circulation; but new spore-formation never occurs under these conditions. There is, so far as I know, only one instance where an infection of man has taken place by way of the intestine. In one species of Mucor a form and arrangement of the $\mathrm{my}$ celial threads occurs which recalls very strikingly the ray-fungus. It is a most remarkable thing that these disease-producing monlds, like Aspergillus fumigatus and flavescens, Mucor rhizopodiformis and corymbifer, although not usually able to act pathogenically, and generally unable to adapt themselves to a parasitic existence, are yet sometimes able to enter immediately upon the production of disease on the sole capital of characters acquired through a saprophytic habit of life. This striking example shows that pathogenic bacteria must 


\section{be carefully studied in their relations to their} saprophytic adaptations, if we do not wish to embrace ideas which have indeed the merit of being convenient to physicians but are in other respects wide of the truth.

[I have thought it of interest to give a brief résumé of Sanarelli's recent papers upon yellow fever. ${ }^{1}$

The most important study of yellow fever that appeared before Sanarelli's investigations were undertaken was that made in I888-9 by Dr. Sternberg, whose researches led to an essentially negative result. Sanarelli, in 7 out of $\mathbf{2} 2$ autopsies made upon the bodies of victims of yellow fever found a specific bacillus (B. icteroides) which he regards as hitherto undescribed. The reasons assigned for the failure of himself and others to isolate this microbe in all cases of yellow fever are: I. That B. icteroides multiplies in the human body only to a limited extent, the complete and characteristic effects of the disease being produced by only a very small quantity of toxin. 2. That this toxin, whether directly or indirectly, facilitates to a remarkable degree secondary infections of all kinds. These secondary infections with the colon bacillus, streptococcus, staphylococcus, etc., may of themselves be fatal to the patient, and Sanarelli believes that the fatal termination of several cases observed by him is to be explained in this way. 3. That these mixed infections not only lead to the speedy disappearance of the specific microbe, but also frequently end by transforming the organism of the patient into a. culture medium for almost all kinds of intestinal bacteria.

The bacteriological complications arising from these facts enhance considerably the technical difficulties of isolating the specific bacilius. Sanarelli did not succeed in finding the germ in the gastro-intestinal contents and is inclined to doubt if it usually occurs there at all; he did, however, discover it in the circulating blood and in some of the important organs of the body, notably in the liver. He refers to the prevailing belief that the infectious material in yellow fever is localized in the stomach and is to be sought for especially in the black vomit, but prefers, for his part, to regard the gastric disturbances as due to the selective action of the toxin, a view similar, it will be remembered, to his interpretation of the intestinal lesions of typhoid fever.

${ }^{1}$ Annales de 1'Inst. Pasteur, June, Sept., Oct., s 897. 
Bacillus icteroides grows readily upon the ordinary nutritive media fluid and solid. It is described as a rod about $2 \mu-4 \mu$ in length, with rounded ends, often joined in pairs, and staining readily with the ordinary aniline dyes, but decolorized by Gram's method. The colonies upon a gelatin plate resemble in some particulars those of the colon bacillus, but never show any trace of the chestnut color developed in cultures of the latter; so-called pleomorphism of the colonies is, however, marked.

Contrary to what is true of most of the known pathogenic microbes, the growth of $B$. icteroides upon agar is especially characteristic and furnishes a diagnostic test of the first importance. If the cultures are allowed to develop in the incubator at $37^{\circ}$ for from 12 to 24 hours, and are then transferred to a temperature of from $20^{\circ}$ to $28^{\circ}$, there is produced what Sanarelli regards as a highly characteristic appearance. The growth at the lower temperature forms a sort of halo around the portion of the colony developed in the incubator, and this appearance is so singular that according to Sanarelli a mere superficial inspection suffices to distinguish immediately, and with the naked eye, a colony of $B$. icteroides in the midst of all other bacterial colonies yet described. As the growth goes on, an effect is produced as if a layer of opaque paraffin had been poured over the agar and then impressions made in it with a small circular seal, the imprints of this seal corresponding with the original transparent colonies grown in the incubator. The final aspect of the culture is compared to a miniature archipelago in which the islets would be represented by the colonies first developed, and the surface of the water by the layer subsequently formed at the lower temperature.

Blood-serum and potato proved themselves to be rather unsuitable media for $B$. icteroides. In milk the germ grows readily, but - without producing coagulation. The most favorable fluid medium tested by Sanarelli was beef broth containing lactose and calcium carbonate.

The germ is pathogenic for most of the domestic animals. Mice, guinea-pigs and rabbits succumb readily to inoculation with a pure culture. The rabbit is considered as the most favorable subject for experimental inoculation, and possesses notable advantages over the guinea-pig both in susceptibility and in the regularity and constancy of symptoms and death. The dog, however, presents the most instructive instance of close analogy with yellow fever as manifested in man. Both in the symptoms and in the anatomical lesions Sanarelli was able to trace a correspondence at once constant and precise. As is the case in man, the liver and the kidneys are the organs es. 
pecially attacked; secondary infections with the streptococcus and colon bacillus sometimes occur.

In the second memoir Sanarelli details the results of his experiments with the yellow fever toxin. - Cultures of the germ I 5-20 days old, made in ordinary peptonized meat broth and filtered through a Pasteur-Chamberland tube, afforded him a potent toxin. The toxin thus prepared, when injected into the bodies of susceptible animals, produced substantially the same symptoms as inoculation with the specific bacillus. In the dog, particularly, inoculation with the germ-free toxin set in motion the same train of specific symptoms and caused the same pathological changes in the tissues. "The toxin of yellow fever is an exceedingly powerful cellular poison comparable solely, in some points, to the diphtheria toxin. Its contact with the tissue elements of the animal organism, especially the higher species, determines, like that of the diphtheria toxin, a violent irritation, followed by retrogressive processes which always end in the necrosis and fatty degeneration of the protoplasm."

Some very interesting experiments bearing on the question of mixed infection are next described. When $B$. icteroides is sown upon culture media on which, the colon bacillus, streptococcus and proteus respectively, have been previously grown, it is found that the growth of the former is distinctly inhibited by the presence of the soluble products of the other microbes. The latter, on the contrary, grow excellently in a medium previously inhabited by $B$. icteroides, and are only slightly incommoded by the presence of the soluble products of one another, the products of the proteus bacillus seeming most injurious to all concerned. A similar result was revealed by a study of the 'vital antagonism' of B.icteroides and the microbes concerned in the secondary infections. Both Streptococcus pyog. and Staphylococcus pyog. au. speedily gain the upper hand over B. icteroides, and a similar, though less marked superiority, is manifested by the colon bacillus. These facts certainly shed much light on the difficulty of demonstrating the presence of the yellow fever germ in the bodies of victims of the disease, and go far to explain the negative result reached by many observers.

In an attempt to account for the important part played by maritime commerce in the diffusion of yellow fever, Sanarelli records a curiously significant observation. It was noticed that gelatin plates sown with $B$. icteroides sometimes remained without development, although agar plates sown at the same time evinced abundant growth. But if a colony of mould made its appearance on the gelatin plate, colonies of $B$. icteroides immediately sprang up around 
it. After some days the colonies of B.icteroides form a sort of constellation around the mould, the most abundant development taking place in the immediate neighborhood of the latter. This observation was experimentally verified with six species of moulds (not named) " accidentally isolated " in the laboratory, all of which proved, although in different degrees, capable of favoring the revivification and multiplication of the yellow fever germ. To this singular symbiotic relation Sanarelli is inclined to attribute the ready domiciling of the disease on shipboard and its connection with warmth, moisture and darkness, conditions which, by directly favoring the germination of moulds, indirectly favor $B$. icteroides.

In some brief notes upon the resistance of the germ to physical and chemical agents it is stated that, by exposure of broth cultures to $55^{\circ}$, the germ is killed in about twenty minutes, and that it is instantly destroyed by a temperature of $65^{\circ}$. Dry heat at $110^{\circ}-125^{\circ}$ is speedily fatal, and exposure for one hour aud ten minutes at $100^{\circ}$ also suffices to destroy vitality. Considerable resistance is shown to desiccation, a result of evident practical importance. In sea water the bacillus shows great vitality, surviving in the sterilized brackish water of the La Plata for upwards of ninety days.

Sanarelli's third memoir is devoted to a consideration of immunity and serum therapy. The serum obtained from the bodies of yellow fever victims causes agglutination of $B$. icteroides, although the intensity of the reaction is said to be quite variable. This serum does not exert any protective power in inoculated animals. Serum from a convalescent provoked a tardy agglutination and manifested a slight preventive power.

An attack of yellow fever in man confers some degree of inmunity against a second attack, and hence it would seem as if it might be possible in some way to vaccinate animals against the disease. Attempts to produce immunity in the rabbit failed on account of the excessive sensibility of this animal to the yellow fever virus, and the same difficulty prevented the use of the goat and the sheep. The work upon immunization was mainly limited, therefore, to experiments upon the guinea-pig, the dog and the horse. In all these animals immunization is an unusually difficult and laborious task. While it is possible to immunize a guinea-pig against cholera or typhoid fever in from two to three months, it needs six to seven months of assiduous and delicate work to vaccinate this animal against yellow fever. Dogs may be immunized somewhat more readily, but never become tolerant of large doses of toxin. Horses are treated first with small doses (5-10 c.c.) of a filtered culture of the 
germ injected subcutaneously, followed with intravenous injections. After two months of treatment with filfered cultures the more potent doses of cultures sterilized by ether may be used; it is not until five to six months after the beginning of the treatment that the first injection of a living culture may be safely hazarded. During this process of immunization many of the animals die and all are profoundly affected.

The serum of animals immunized in this way is endowed with protective and curative properties and can be used with success in animal experiments. A single instance may serve to illustrate the results obtained by this procedure. A horse under treatment for the space of nine months received subcutaneously during this period 29c.c. of filtered cultures and 350 c.c. of cultures sterilized with ether, and intravenously 2640 c.c. of sterilized cultures, 345 c.c. of living broth cultures and I9 c.c. of an agar culture. The serum (0.5 c.c.) from this animal, when injected into a guinea-pig 24 hours before inoculation with several times the fatal dose, conferred immunity; 2c.c. proved potent enough to save the lives of guinea-pigs when injected 48 hours after inoculation.-E. O. J.] 


\section{CHAPTER IV.}

THE CAUSE OF INFECTIOUS DISEASE.

THE wish "to know the cause of things" is as old as mankind itself. In medicine the scientific period may be said to dawn at the moment when the question as to the connection of disease with environment was clearly propounded by Diodorus and by Hippocrates, "the father of medicine."

In former times men were generally satisfied, and they are frequently satisfied to-day, with the vaguest conceptions of things, conceptions based on the common ground of a search after animate causes or personifications. Universal knowledge is plainly unattainable in any given section of time; hence men have always been forced to piece out in imagination part of the lacking facts,-that is to theorize; and the form such speculation assumes is naturally in accordance with the measure of cultivation prevailing at the time. Even now, as is clearly shown by the conceptions of image-worship among both the educated and uneducated there weighs upon wide strata of society an impera- 
tive necessity for personification, for animate cause. Men abandon the idea of such animate causes only after more profound thought and arrive first at a mechanical, then at a monistic conception of the universe. Guided by the pervasive, all-embracing law of the conservation of energy, the exact sciences have everywhere struggled through to a mechanical, and in part even to a monistic standpoint. The extraordinary complexity of the phenomena which confront us in the consideration of the origin of disease doubtless accounts for the fact that up to this time no one of the conceptions in medical theory,-either the dominant ones or those in direct conflict with them,have been freed altogether from the old mystical animism. For this very reason not only do scientific periodicals resound daily with the clash of antagonistic principles, but the conflict is continued in the daily press and even in the conversations on street corners.

In the presence of the great pestilence which the Greeks before Troy ${ }^{\mathrm{I}}$ ascribed to the arrows of the offended god Apollo, Homer makes the father of gods and men say:

"Lo, how men blame the gods! From us they say, spring troubles. But, through their own perversity, and more than is their due, they meet with sorrow."

1 The passage in question occurs in the Odyssey I., 32-34-E. O. I. 
This notion that pestilences are punishments for sins, and that they can be combated by sacrifices, prayers, and pilgrimages, survives to-day in the midst of civilized Europe, an example of the deep-rooted proclivity in untrained minds towards a search after the animate, towards ontological speculation. The convenience of this ontological conception has given to the bacteria, as if in pure mockery of all scientific thought, an opportunity to celebrate their resurrection as the true disease-entities. Now, indeed, every sewing-girl knows that these good-for-nothing bacteria are the cause of "fevers." Given the specific germ and the supposition is that we know everything needful; methods of fighting the disease, of disinfection and of healing are mere unimportant details. We cannot enough scorn those older physicians who knew nothing about bacteria, but who could not bring it into harmony with their better philosophic schooling that these things should be suddenly presented to them in pure cultures and in beautifully colored microscopic preparations, as the cause of disease. But in truth a sound kernel lay in their criticism. It was in a kindred spirit that Liebig ridiculed Pasteur, remarking à propos of Pasteur's statement that the yeasts were the cause of alcoholic fermentation, that one could not see 
causes. Physicians, however, were not embarrassed by such considerations and, under the influence of Koch's ingenious methods, it became a pastime to show the causes of disease in pure cultures; the amusement flourished even in the drawing-room, and the phraseology of the new game became popular everywhere.

We shall probably best reach a scientific understanding of the significance of bacteria in the origination of disease if we consider briefly the chief ideas hitherto held concerning disease. The conception, now generally embraced, of a "specific infectious disease" presents itself first in the writings of the great English physician, Sydenham. By this term is understood a sharply defined characteristic malady which, in uncomplicated and "typical" cases, is clearly distinguishable in its course and symptoms from other diseases ; measles, smallpox, scarlet fever, malaria, pneumonia, and cholera are such "specific infectious diseases." It was precisely this individuality of the "typical" cases that pointed to an individuality of origin, and in exactly this general sense Sydenham first compared "species of disease" with species of plants. In the eyes of this physician, therefore, the "specific" disease itself was an "entity," it was personified. To have done away with this conception is one of the great services of Lotze 
and Virchow, who recognized more clearly than their predecessors that disease, as well as normal life, is a process. A process, a mechanical or dynamical process, cannot, however, be a living entity; and hence Lotze and Virchow struck a fatal blow at the unscientific notion of a disease essence. Something in addition to this notion, however, dwelt in the conception of Sydenham, namely the observation that the "specific" disease must have a cause, although he did not separate sufficiently the conception of a predisposition to disease from that of the cause of disease. He recognized further that the character of the specific infectious disease varies greatly in different epidemics, and attributed this variation to the genius epidemicus, without remarking that the term expressed a fundamental departure from his conception of rigid disease types.

From the manifest opposition between Sydenham's conception of a "disease species" as an entity, and Lotze and Virchow's conception of disease as a process, we are able at once to understand Virchow's direct and vigorous opposition to those bacteriologists who still stick fast in the fetters of ontology, and for whom disease-producing bacteria are only mystical entities which they would like to set in the place of the older personifications of priestcraft 
to be worshipped by devout physicians and laity.

Virchow, following up the process of disease as far as possible, came at last upon the diseased cells. Here he too fell into a singular error. He set up the diseased cell as the essence of disease, thereby substituting another entity for the one he had just thrown down. It was a weak place in the cellular pathology and one which Virchow's opponents were of course quick to attack, without, however, giving due consideration to one point in his theory, namely, that he did not lose sight of the disease process in his contemplation of the diseased cells as the microscopic disease entities. He rightly conjectured that the something that appeared as disease must be something that was already preformed in the normal organism. As the cause is essential to its effect, so the production of disease requires an inward predisposition. Lotze had already expressed himself in a similar way.

In regard to the normal processes of life the same principle had been established for a long time through the investigations of the German physiologists Haller, Reil and Johannes Müller. Whatever be the outside forces that act, the eye perceives only light, and the ear only sound; the glands simply secrete and the muscles con- 
tract. It is therefore the internal condition of the organism, of its organs, tissues or cells, that alone determines the character of the effect. The impulse that must come from outside to produce these effects is called the stimulus. Hence there must exist a fundamental internal organization, that is to say, a predisposition to something external. Since also the physiological manifestations remain the same, while the character of the stimulus varies, the true cause of the manifestations must lie in this internal organization. The intrinsic predisposition is physiologically the true and sufficient cause, and therefore the sole cause of the normal processes of life. On this side Virchow and Brown indeed recognized the fact that a quantitative excess in a normal stimulus may be the cause of disease; too much light, for example, produces blindness. The effect of a stimulus may likewise be too great if the natural predisposition of the organism be too feeble, although the stimulus itself is still within physiological limits for a normal organism. Disease, then, may be regarded as the effect produced by quantitative changes in normal conditions, either when the physiological organization is too feeble or the stimulus too intense. Apparently, at least, infectious diseases which were presumed to introduce an entirely new 
qualitative element scarcely fitted into this conception. The doctrine of the causation of infectious diseases is accordingly not indebted to Virchow for its furtherance nearly so much as are other realms of pathology.

On the other side, those investigators who were dissatisfied with Virchow's explanation fell into the opposite error in their own investigations. The Viennese doctor Plenciz had expounded very clearly and more fully than any one had done before him the doctrine that the cause of disease must be sought in the existence and activities of minute, specific living things. Afterwards Eisenmann and still more acutely Henle set forth this parasitic theory of infectious diseases, which grew then steadily stronger through the added force of important discoveries. In our own time, through the work of Davaine, Pasteur, Klebs, F. Cohn, J. Schröter, and Koch, it has become the prevailing theory. By his statement of this theory Henle was thrown into just as sharp opposition to Virchow as Koch has been recently, and at that time was forced by Virchow's want of consideration into other lines of activity, a fact that enables us to understand many personalities in current controversy.

The now well-established parasitic theory of disease asserts that every "specific" infec- 
tious disease is caused by a "specifically" characteristic small living thing or microbe. Most of these microbes-but not al1belong to the group of bacteria. These bacteria, which are therefore entities altogether external, are, as Koch has set forth with great clearness, the sole true and sufficient cause of the infectious diseases. Differences in these diseases are due to differences in the small living things at the bottom of the process, in the disease-producing bacteria alone. In short, bacteria constitute the "entities" of infectious disease. According to the theatrum diabolorum, the view prevailed in the Middle Ages that "every $\sin$ is under the control of and operated by a particular devil"; at present each disease in similar fashion has its own devil in the form of a specific bacillus. Beelze$\mathrm{bub}$, the god of invisible evil flies, is peculiarly the protecting patron of the "specific" bacteriologists.

Between this conception-a matter in which the French daily press finds. its oracle in Pasteir and the German in Koch-and the conception of Virchow, there exists a profound antagonism. It is the same conflict that prevailed between Liebig and Pasteur over the physiology of fermentation. Liebig sought the cause of fermentation, as Virchow did that 
of disease, in the internal constitution of the fermentable substances, while Pasteur conceived the cause to be the external and visible yeast-cells. This conflict of opinion is now still further complicated by Pettenkofer's theory that, at least for certain diseases such as typhoid fever and cholera, the determining cause or essence is to be found in the external conditions which vary according to time and place. Here we have put forth as the true and sufficient cause of epidemic disease three wholly dissimilar things, upheld by three different schools, and which are all treated as "entities" or personifications. Virchow finds an internal cause in the diseased cells, his opponents see an external cause in the germs that bring about disease, and Pettenkofer sees a cause in those external conditions which play no particular rôle either in the eyes of. Virchow or in those of Virchow's chief opponents. At the same time, however, it must be said that Virchow consistently attempts to break free from the personification idea and to arrive at some conception based on the comprehension of processes.

I shall now attempt to show what is false in each of these conceptions and what is scientifically tenable, and in so doing I shall point out that all these investigators recognized a 
part of the truth, but that no one of them attained to a real comprehension of the continuity of causes in the sense of modern exact science. I hope also to show that the existing antagonisms resolve themselves into a higher unity by means of which the solution of the problem becomes again surprisingly simple, a result quite common in cases where each such antagonistic principle is unduly inflated that it may redound to the glory of its school.

\section{Causes and Their Identity and Equivalence With Effects.}

While the modern investigator in the exact sciences holds the conception of cause and effect only in a unitary or monistic sense, and while in epistemology there is a similar understanding of these terms, among the people at large the word cause connotes quite different meanings. Sometimes the word is used in the same sense as it is by the man of science; such a case is the recognition in reference to an explosion that the degree of destruction is dependent upon the kind and quantity of the explosive material. Sometimes, however, we characterize as the cause the spark or the electric current which precedes the explosion and evokes it. In the first case the cause is some- 
thing internal and exactly concurrent with the effect, in the second case the cause is something external which neither qualitatively nor quantitatively stands in any sort of congruent relation with the effect. In order to eliminate this double sense of the word cause and to put an end to all confusion, a general agreement as to its usage was reached in connection with the discovery of the law of the conservation of energy by R. Mayer and his successors, and this usage has generally been conformed to in epistemology also.

If potential energy or the capacity for doing work is transformed into kinetic energy or actual work the two are equal in quantity. They pass over quantitatively into one another, and the work appearing as effect accurately corresponds to and is measured by the initial capacity for work as cause. The true and sufficient cause of any effect is always something internal, something that follows from the kind and amount of the initial energy, and from that quality and quantity alone and entirely. This is the conception of a cause,-Ursache-, an idea which the German language can express so felicitously, while other languages must paraphrase it (in Latin, e. g., causa prima or princeps, to which the further definition causa interna and vera or 
sufficiens are necessary for completeness) in order to represent everything that the prefix $U r$ denotes to a German. It is the absolute thing "that exists behind all change and remains primordially the same" as Helmholtz expressed it. This alone we now call cause, - Ursache,-both in the exact sciences and in epistemology, and we accept nothing but that conception as true and sufficient. Only what is provided for in the cause both in quality and quantity can appear as effect, and everything that appears as effect already exists in quality and quantity in the cause, that is, in the internal organization.

\section{Resistances and External Conditions.}

In a strict sense causes may pass over of themselves, freely and spontaneously, into their effect, as when a thrown or lifted weight immediately falls. In practice, as a rule, this does not happen, since in order to render a definite work possible, we prevent the raised weight from immediately falling again by hanging it up by a cord or by placing a support under it. Such a resistance to the immediate conversion of potential energy into work may be removed in a given case easily or with difficulty, and a corresponding appli- 
cation of external energy is necessary in order to do away with the resistance and so bring about the actual fall of the weight just at the right moment. The removal of the resistance, as compared with the actual conversion of the capacity for work into work, is in itself something purely adventitious; the conversion comes about now easily, now with difficulty, now in this way, now in that, according to the given external conditions. When uncertainty existed about such connection, therefore, the expression "occasional causes" used to be employed. Such modifying conditions are not necessary to the effect, they have not in themselves the character of true causes, but they are practically important. Corresponding to every form of potential energy there exist by. virtue of the external conditions, definite initial circumstances and kinds of resistance which determine whether a given form of potential energy, a given possibility of work, a given internal cause can be converted easily or with difficulty or not at all into kinetic energy, into work, into effect. So long therefore as the external conditions remain the same, the same form of potential energy must be convertible with the same ease into kinetic energy, the cause into the effect. If the conditions change, then the transformation may take place more 
easily or with more difficulty or not at all, since by altering the conditions the natureand amount of the resistance may be changed. This quantitative conception of conditions was first set forth by me at the Naturalists' Meeting in Nuremberg in I893, and Mach at the same time showed that the constancy of conditions is full of significance likewise for the constancy of physical processes.

\section{The Liberation of Energy.}

If the conversion of cause into effect, of potential energy into kinetic energy is prevented by any sort of resistance, such conversion can obviously take place only if this resistance is removed. This process may be-callèd, with R. Mayer, the liberation of energy, and the external forces which accomplish this are called liberating impulses. I have shown that we cannot content ourselves with neglecting these liberating impulses as of minimal amount, but that they are connected in a definite and quantitative way with the liberation of energy; the impulse must always introduce energy enough to overcome the resistance.

A11 changes of one form of energy into another are visible or invisible movements, and the impulses that set free the energy are like- 
wise transmissions of a movement. Because of the continuity of energy, therefore, every form of liberated energy acts through the transmission of movement in such a way as to set free other forms of energy. In the processes of disease external signs of this process are afforded in the succession of changing symptoms. The impulses that set free energy are something external, and under certain conditions may be altogether lacking; it is at least redundant to speak of liberating causes.

We now know of course that small causes produce not great, but only small effects, whereas small impulses, when of sufficient power to overcome resistances, may set free great effects. 'The effect is always a process, not an entity, and the causes which alone produce the effect are internal. External conditions and external impulses are always links of unequal value in an endless chain in which a movement exists. Breaking the chain at any one point makes the production of the effect impossible.

It is in itself a matter of complete indifference what notation one adopts. I have myself decided upon a definite and unambiguous terminology and thus reached clear-cut and definite conceptions. Such a terminology is applicable in all realms of human science, and 
therefore should make an end once for all of the loose terminology which has been in vogue in medicine. When I presented this view at the Naturalists' Meeting in I893, the objection was made from varions sources that, in view of the incomplete theoretical knowledge and scientific training possessed by many physicians, my exposition was somewhat too recondite. I have tried now in this way to make it sufficiently clear that in the exact sciences there is absolutely no place for the toys of ontology, for entities or for essences, but that we must deal with dynamic phenomena, with processes which interlock with one another. That, I trust, is the plain sense of my detailed exposition.

I now hope also to show in a.way intelligible to my readers that even in the organic kingdom and especially as regards the doctrine of the origination of infectious disease we have no place for the "entities" of Sydenham's "specific disease," or of Virchow's diseased cells, or of Pettenkofer's determining circumstances of time and place, or of Pasteur's, Kleb's, - F. Cohn's, and Koch's "specific " disease-producing bacteria. I hope further to show that, in considering the origination of infectious disease and the dynamic processes which are concerned, we can take account of 
all these things without degenerating into the mysticism of ontology. Although Behring rates it as one of Koch's services to science that he established the entity of disease by setting forth the bacteria as the specific cause, yet it is clear that in adopting such a conception scientific medicine would take a long step backwards. In such a confusing state of affairs a clear and unambiguous terminology has always been an advantage. This, however, some of my opponents who are adherents of the bacteriological ontology, did not seem to appreciate, because it is advantageous for any exploded theory to have a vague, ambiguous nomenclature. This is plainly in order that its advocates may be able to say, after each 'new victory of science, that they had always really meant something quite different from what every reader of their works had previously supposed them to mean.

\section{Atomic Combinations and Resistances.}

When organic substances are built up out of the elements or out of very simple compounds, there always results as the product of such a synthesis not only an increased number of atoms in the molecule but an increased number of combinations of atoms. The indi- 
vidual atoms are more firmly bound to one another in the very simple molecules that serve as a starting-point than they are in the complicated synthetic products. Carbonic acid and water, out of which starch and sugar are formed by green plants, are simple molecules, and the atoms in the molecule are firmly united as compared with the more complicated and more unstable molecules of starch and sugar formed out of the same atoms. Carbonic acid, water, sulphuretted hydrogen, ammonia, and nitric acid, all of which may enter into the synthesis of proteid are very simple, stable atomic compounds compared with the loose and complicated combinations in which these same atoms are bound in the proteid molecules. Along with an increase in the number of atoms in the molecule not only the number of atom-groupings increases, but generally also the looseness of combination. Conversely also, if a complicated and unstable molecule be broken down, and fall to pieces into simpler and more stable compounds, the ease with which the breaking-down is accomplished and the number of possible new combinations must be in general dependent upon the complexity of the demolished molecule. In a molecule built up out of simple compounds there exists just as much energy or 
internal cause as has been expended in its construction. The manner in which the atoms are grouped or bound together produces also a definite resistance which may be overcome with more or less difficulty.

In these cases, therefore, the resistance bears a much closer relation to the store of potential energy than in most cases in inorganic nature; the resistance is a direct consequence of the process of construction, and therefore a property of the molecular structure. In the structure and constitution of every organic body the total amount of energy which may manifest itself as effect exists as the potential energy of combination, as the internal cause. The kind of energy is prefigured also in the molecular structure, and so, finally, is the kind and amount of resistance which prevents the immediate and free transformation of cause into effect. I have explained the reasons for the latter phenomenon briefly, as it is unnecessary to consider details in this place. The looser and more manifold the atom-grouping of a molecule is, the more energy the molecule contains; so much the less also is the energy needed to overcome the resistance and liberate the energy of the molecule, and so many more are the different kinds of external impulses which are able, by the application of aniso- 
chronous movements, to overcome the resistance and convert the potential energy into kinetic, the cause into effect.

In purely inorganic processes the liberating impulses either bring about an effect or do not bring it about according to the extent to which they are quantitatively adapted for the removal of resistance. The quantitative effect of the liberating impulses bears a relation to the quality of the potential energy set free only through the particular form of motion involved. In the liberation of the energy of complex organic molecules, on the other hand, the impulses bear more of a qualitative relation. But whether they can or cannot make themselves felt in such a qualitative way again depends in the last instance exclusively upon the character of the molecular structure. The nature and amount of the resistance offered depend also upon the structure, that is to say, upon the internal organization of the organic substance upon which a liberating impulse impinges. Resistance in this case is therefore in plain terms a result of adaptation, while in the inorganic realm it often results from the simple juxtaposition of different processes and their reciprocal action.

Accordingly in our inquiry into the causes of organic processes we meet all those phe- 
nomena that we find in inorganic processes, but they are better regulated and more intricate, in the first place because of adaptation, and in the second, because of the complexity of the phenomena involved. We find various forms of potential energy or internal causes which may be transformed into kinetic energy, into work or into effect. The effect, so far as its special features are concerned, depends solely upon the qualitative character of the compound, that is to say, the mode of union of the atoms in the molecule. This qualitative relation is more striking in the realm of the organic than in the inorganic, where it has been recognized from the time of R. Mayer to that of Hertz that qualitative relations may be overridden. At bottom, however, exactly the same subjective limits wall us in, although that is a fact that need not be dwelt upon here. Every quality is of course from one point of view a sort of sense-illusion or sense-limit, and not anything truly objective. We find forms of resistance, then, which result from characteristics of molecular structure and therefore present not only the well-known quantitative but also a qualitative side worthy of consideration.

Finally we need to consider the liberating impulses which quantitatively and qualitatively serve to remove the resistance. We 
must now picture the problem to ourselves in a somewhat different way, because in the historical development of the subject the aspect of quality so predominated that the quantitative side was wholly overlooked or not recognized, and only Liebig, Lotze, Virchow, and Naegeli suspected the existence of and partly recognized individual factors of this kind.

The explanation of the fact that a long time elapsed in the natural sciences before the dualistic contrast between organic and inorganic was abandoned is that the conceptions of the Critique lingered long in men's minds. Kant was a dualist, and for him inorganic processes were the consequences of necessity; organic processes, of purposiveness. Schopenhauer found quantities in inorganic processes, qualities or stimuli in organic. Unfortunately dualism in the latter form still haunts the minds of many physicians who often never suspect its retrogressive character as compared with the mechanical and monistic point of view.

Predisposition to Disease: Acquired and Inherited.

As the result of inheritance, individual development, and adaptation to existing conditions of life, every man,-and man is the sub. ject I place from now on in the foreground,- 
possesses within his organism, that is in his organs, tissues, cells and body-fluids, at a given time and place, a definite kind and amount of potential energy or cause. This, when it becomes manifest, we designate variously as a physiological property or irritability, as a morbid susceptibility, as a predisposition to disease, or as immunity. A predisposition to certain diseases exists among different races and species. Negroes for example are infected with smallpox much more easily than Europeans, while the latter not only sicken more easily with yellow-fever but the disease assumes in them a more fatal character. Variation in susceptibility to disease is also found among individuals of the same species, as is established by such a fact as that among our population only 3 to 7 per cent. contract cholera, while others of the population, although under the same conditions, resist the disease. In spite of the ample opportunities of infection with tuberculosis which are afforded every one, only some 20 to 25 per cent. of the population really contract any form of the malady. Indeed, if we consider the most dreaded of all known infections, the Black Death of the Middle Ages, we are told that only one fourth of the whole population of Europe contracted the disease, some 75 per cent., therefore, 
being naturally protected, while it is reported that the small-pox in Central America destroyed one-half of the native inhabitants.

That the different organs of the body possess different degrees of predisposition to disease may be inferred from the fact that diseases which are now known to be infectious were once regarded as organic, as, for instance, inflammation of the lungs and catarrh of the intestine. The striking fact that different organs are attacked by tuberculosis, and that the disease selects different organs at different periods of life beautifully illustrates this point. The experience of physicians, and the vast material placed at our disposal in statistics of disease and death have, in short, shown the existence of a predisposition to disease and have made it clear that susceptibility to different diseases varies greatly according to the period of life and according to sex.

Plant parasites furnish some fine examples of predisposition. Laboulbenia musce is found only in the house-fly. Cordyceps, on the other hand, occurs in the larvæ of different butterflies and other insects. Phytophtora infestans occurs only upon potatoes, while Phytophtora omnivora attacks a number of other plants but not potatoes. Species of moulds of the genera Pythium and Sclerotinia attack only plants 
that are young and rich in water and therefore less resistant, but do not attack the older plants which are less rich in water. Cystopus candidus, according to De Bary, causes the white rust of the garden-cress (Lepidium satioum); all plants, in fact, are susceptible to the attack of this fungus, but only when they are in the cotyledon stage; when the cotyledon falls off the leaf becomes resistant and the spores and germ-tubes of Cystopus penetrate only locally in every case, without being able to push far into the interior. The blister-rust of spruce needles occurs according to Cramer in its other parasitic forms only upon the leaves of the Alpine-rose and wild rosemary, Chrysomyxa rhododendri and ledi. In localities where these two plants do not occur no blister-rust is found upon the spruce. Similar relations exist according to De Bary, between the rust of wheat and the æcidia of the barberry. The "local" disposition is, therefore, in reality the local presence of the host. According to De Bary, if the "disease predisposition" due to the presence of the host be removed-e. g., if the barberry bush be banished to a distance-the disease disappears, only to arise again when susceptible host-plants are introduced.

Perhaps the most remarkable fact in this connection is that definite predispositions may 
be acquired as the result of external changes. An attack of illness due to " catching cold " or of rheumatism-affections causally related perhaps-increases the tendency to those diseases, while an attack of any one of the more acute infectious diseases, such as small-pox, scarlet fever, or measles, confers immunity against another attack. Susceptibility to disease is transmuted into protection against it. Such an individually acquired immunity can be handed on from mother to child. I shall not in this place broach the much mooted question whether or not acquired characters can be inherited, and shall not try to set forth here how, upon the basis of my representation of the problem of causation, the question really comes within our reach. It may suffice at present to make clear that, under certain circumstances, acquired characters, among which may be reckoned acquired tendency to disease or acquired immunity, must be inherited. According to Kaltenbach, twin-sisters, originating from two different ova, were exposed in equal measure to infection from scarlet fever; one of them remained en'irely immune, the other succumbed inmediately. The latter resembled the father, the immune child the mother, who, fourteen months previously had experienced a severe attack of scarlet fever. Here was a pronounced inborn 
quality, but this quality was inherited, and the character thus transmitted was originally acquired through disease. An interesting observation has been made in certain cases of twins and triplets. When, by infection of the mother with small-pox opportunity was given for placental, intra-uterine infection of all the offspring, one or another of the children remained free from the disease, although the possibility of infection taking place by means of the placenta was proved by its occurrence in the case of one or more of the children. But it has also been observed that a pregnant woman who had been successfully vaccinated gave birth to a healthy child who nevertheless sickened three years later with small-pox, and in another case small-pox was observed in a fœtus whose mother had previously suffered with the disease. Whether an acquired disposition is transmissible depends upon the kind and duration of the influence. On this point it is easy to deceive oneself. In Ehrlich's experiments in regard to rendering animals resistant to poisons, at first sight it seemed as if the young inherited immunity; another interpretation proved, however, to be the correct one. The young of a non-immune mother, when fed oil the milk of an immunized mother, acquired immunity, thereby showing that the immunity 
was not conveyed by direct inheritance. It was instead an instance of extra-uterine, individual immunization brought about by means of the protective substances contained in the milk of an immune mother or nurse. According to Tizzoni, however, immunity to tetanus acquired by the father can be transmitted to the offspring. ${ }^{\text {. }}$

The existence of a definite predisposition to or immunity to disease is dependent upon the inherited organization of the body, and, upon its adaptation to the conditions of life, among which may be numbered not only soil, water, air, and the general factors of weather and climate, but also social conditions. These changing circumstances or external conditions act upon the internal disposition which remains always the same. If these conditions change, then readjustment must occur, that is, changes in the internal constitution must take place. Every change in environment, every considerable change in nutrition may, therefore, make itself felt by its effect upon our predisposition. By utilizing the information gained from experiments along this line we have at our disposal a means of influencing the disposition in our favor, as, for instance, by the removal of

${ }^{1}$ Later experiments have failed to confirm the statement that an immune father can transmit immunity.-E. O. J. 
social mal-adjustments, by improvement of the locality in which we dwell, by changes in metabolism through the introduction of better nutriment, or by regulation of the temperature conditions of the body. Finally, we are able to make use of the fact that by undergoing a disease the predisposition to that disease is removed and converted into its opposite, immunity.

In no case can anything appear in the form of disease which was not previously present in the body as a predisposition; external forces are able merely to make this predisposition apparent. It is therefore at the outset important to hold fast to the fact that we are in a position to act upon a given physiological organization by a whole series of changes in external conditions; we can either heighten a predisposition or remove it. Herein lies also the reconciliation of the physician's art, which has reference to the individual, with the official health regulations, which have regard to the conditions making for the betterment of all. When the physician, by thorough observation and investigation, knows the conditions that influence a given disposition in a definite way, when he is scientifically trained and has a true conception of hygiene, and is at once physician and naturalist, then he is able to cure disease 
by use of the very same forces which serve to create or alter the human constitution. In this simplesense there is a true art of healing.

The external conditions to which a human being is subjected according to season and locality make themselves felt throughout the organs, tissues, and cells of the whole body. This they do through the mediation of metabolism and by the aid of the nervous system, factors that determine the character of the synthesis or the building up of the organism, and, as before mentioned, that determine also the kind and amount of the resistance that hinders release of energy. We are accordingly set the further task of guiding the course of events by the use of those conditions that create resistances, and guiding them furthermore in such a way that the physiological resistances are naturally and readily overcome, and the liberation of energy follows easily and in normal paths, while all sorts of pathological resistances are avoided and the pathological setting-free of energy prevented. Since the kind and amount of resistance met with in the organic kingdom is a consequence of organic structure, this task practically coincides with the first, namely that of influencing by the aid of suitable external conditions the potential 
energy or the cause, or, in a word, the disposition of men.

\section{Disease-Stimuli.}

The liberating impulses, as they are called in the inorganic sciences, are called stimuli in speaking of normal life-processes, and we may speak of the particular stimuli that evoke disease as excitants of disease, as Liebig spoke of the excitants of fermentation.

Through a depression of the physiological organization and a consequent lowering of resistance, normal physiological stimuli may become disease stimuli; or, the organization and resistance remaining the same, a normal stimulus may become more intense and be converted into a disease stimulus; in other words, the stimulus may come into play only quantitatively. If this be so, it is easy to understand how the kind of effect that we call disease depends qualitatively upon the kind of organ, tissue, or cell concerned, and indeed solely upon these and their internal adjustments (Virchow). If the disease stimulus, however, be a living thing, then, according to Koch's conception, this natural law would be summarily abolished and the quality of the disease stimulus, that is to say, the kind of disease-producing bacteria, would determine 
the disease, or bring about the effect. We find only apparent support for this latter view from such facts as that anthrax bacteria always evoke anthrax, and tubercle bacilli tuberculosis in susceptible animals, and that many diseases, such as malaria and pneumonia, have a typical and often cyclical course. If the facts are considered attentively, they reveal a state of affairs really quite different. If we suppose that the pathogenic bacteria are "specific entities," that they are the true and sufficient cause of disease as Pasteur and Koch have affirmed, then at least four conditions would have to be fulfilled. First, the disease-producing bacteria should exert no other effect than that of producing disease; second, their ability to produce disease should remain constant; third, they should affect all animals in the same way without reference to particular species; and fourth, they should produce only a single, sharply defined, typical and "specific" infectious disease. In such a way as this Koch has really pictured things to himself,- - this is indeed the leading motive of his school-while Pasteur who also originally looked upon the question in the same way, later adopted other opinions. The dogma of the "specificity" of the minute organisms that excite disease, the belief in the existence of pathogenetic or pa- 
thogenic bacteria, meaning thereby belief in unvarying specific character and physiological effect, was especially developed by Henle and later was worked out by Davaine, Pasteur, J. Schröter, F. Cohn, Klebs, and Koch. Other investigators, among whom I need name only Naegeli and Billroth as the leaders, have maintained, in opposition to this view, that bacteria are constant neither in kind nor in action.

Now in the first place, are disease-producing bacteria capable of producing any other effect than that of disease? By the modern method of pure cultures it has been established beyond all doubt that disease-producing bacteria do indeed display other activities ; the successful culture of pathogenic bacteria is in itself a proof that such bacteria are not restricted to a parasitic existence and to the exciting of disease. Thus for example the bacteria of glanders develop a brown pigment upon potatr; the cholera bacteria form a yellow or brown pigment upon potato and in sugar solutions cause an acid fermentation ; the so-called golden pus cocci, which are the most common pyogenic bacteria, form in cultures a splendid yellow pigment and in sugar solutions produce acid. Whereas formerly, in accordance with F. Cohn's view, bacteria were distinguished according to their 
"specific" activities and characters into disease-producing or pathogenic; fermentationcausing or zymogenic, and pigment-forming or chromogenic, the foregoing examples show that a single bacterial species, a single "specific" minute living thing is capable of exercising all three of the specific activities formerly held to be essentially distinct. The "specific" bacteria are therefore not the true cause; that lies in the character of the nutrient medium; the bacteria can elicit only what is preformed in the structure of the medium. I have given the name of " cycle of activity" to this class of phenomena. These facts plainly militate against the doctrine of "specific" disease germs held by Cohn and Koch, and they help us to understand one important thing concerning the production of disease, namely that it is not the transferable " essence" that determines the character of the "specificity" of disease, but the similarity and the permanency of the conditions of life. Since disease germs that are presumed to be "specific" are able to cause fermentations and to form pigments, it is clear that a close relation exists between the "parasitic" bacteria occurring in living human beings and the so-called "saprophytic" bacteria, or bacteria of putrefaction, which are able to live outside of the human body upon 
dead, lifeless, organic or inorganic material. Such relations are sometimes very easily traced, but are often obscure and in other cases are wanting. The parasitic organisms may accordingly be separated into obligatory parasites, facultative saprophytes, and facultative parasites.

In the group of obligatory parasites the dependence upon processes of putrefaction, and the ability to live at the cost and by the destruction of lifeless food material, have gradually been completely lost, or at least such relations have up to the present not been made out. In this group may belong perliaps the yet undiscovered germs of the so-called acute exanthemata like smallpox, scarlet-fever and measles, and also the germ already discovered in relapsing fever. The facultative saprophytes are those germs that we find as a rule living as parasites, but which, under special conditions, can maintain themselves also upon lifeless material, and by breaking down this lifeless nutrient substance are able to grow, multiply and perpetuate the species. Such a saprophytic condition has been brought about in the case of the tubercle bacillus by Koch and by Fischel, one of my pupils, and I was able to show that this organism, which up to that time had been called tubercle bacillus is only 
the parasitic form of a pleomorphic microbe, the other forms of which make their appearance only in the course of its saprophytic existence and were hence at first entirely overlooked. The group of facultative parasites comprises those species which can maintain and reproduce themselves in a purely saprophytic way upon lifeless material without ever necessarily attacking living hosts as parasites; indeed to attain certain stages of development it is necessary that they should live the life of real saprophytes. - To this latter group belong the majority of the disease-producing bacteria now known, such as the bacteria of anthrax, typhoid fever, and cholera.

Finally, there are bacteria which in a strict sense never invade the living organism, but yet are dangerous and able to provoke disease. Many of the bacteria of putrefaction are able to generate out of lifeless nutrient substances poisons that can act injuriously on human beings without participation of the poison-forming bacteria themselves. This may even happen in the normal organism during intestinal putrefaction, a process which seems in itself to have become necessary as a result of adaptation. Such bacteria may be designated as œco-parasites, and may be regarded as forms on the road to become facultative parasites. 
The organism may also be affected through the removal of protective structures of the body by the action of putrefactive poisons ; for example, the intestinal epithelium may be destroyed; saprophytes may then enter into the dead tissues, and may even penetrate still farther into the body, as for instance into the nearest lymph glands. The common bacterium of the large intestine, $B$. coli communis, can do this. There are found, furthermore, transition forms between the different groups of parasitic microbes, so that it is evident that we are not here dealing with rigid groups, but only with a division which enables us to recognize more easily the characters important from a human standpoint. In the process of putrefaction, then, a process which forms an absolutely necessary link in the cyclical course of matter, are found represented the fundamental phenomena of parasitism out of which by development and adaptation to living hosts the various and more advanced stages of parasitism have arisen.

Putrefaction may exert in other respects an important influence upon the excitation of disease ; volatile or soluble poisons of putrefaction may weaken the living organism so that it can be attacked more easily and successfully by the true parasites or by their toxins. The 
mere presence and growth of certain saprophytes acts in such a way that disease germs following in their wake can get lodgment upon man the more readily, while on the other hand other saprophytes may hinder the lodgment of pathogenic organisms. Among the various effects produced by saprophytic microbes outside and inside a living host must be included those that either favor or hinder the lodgment and action of disease germs. That is to say, these microbes act upon the disposition toward disease. They present therefore only individual cases, albeit particularly difficult to evaluate, of external relations or conditions which may now exalt an existing disposition to disease, now diminish it or remove it altogether.

This explanation should make it no longer difficult for the reader to understand the very various modes of action of disease-germs in man, since every possibility of action has developed out of two activities already manifested in the process of putrefaction, namely out of the formation of poisons by bacteria, and out of bacterial growth and multiplication. At one extreme, therefore, we find a kind of parasitic action in which not the bacteria themselves but the poisons formed by them and absorbed into the circulation are the more important factor, while upon the other side stand those 
parasites which act especially through the formation of local growths or tumors. To the latter class belong the germs causing tumors, which have been investigated with especial ascuracy among plants, and a well-known example of which is the germ of human tuberculosis; to the former belong the germs of diphtheria and tetanus; the cholera germ also approximates to the former group. Between these extremes stand the other pathogenic bacteria: in some the proliferation of the bacteria, in others their production of poison is the predominant factor. Disease-producing bacteria may therefore affect man in very different ways. They may cause changes by growing and multiplying in vital organs and through thus altering the metabolism of important tissues may influence unfavorably the metabolism of the whole body; or they may rob the body of important nutrient material and introduce the products of their own metabolism into the body of their host : or they may, in the act of satisfying their own need of energy, split off from the proteids of the human body certain substances which act upon man as poisons; or they may themselves generate poisons in their own bodies and, like poisonous plants, be in themselves poisonous. The mode of action may vary according to conditions; for 
example, ergot is a local growth for the grain, a poison for man.

In all cases, from the simple germs of putrefaction and the œco-parasites up to the obligatory parasites, one thing is a pre-requisite to successful invasion, namely, that as compared with the mechanical or chemical attacking powers of the microbe the mechanical and chemical resisting powers of man be relatively feeble or impaired. If this is not the case the human organism either does not allow the germ to gain entrance to the body, or when entrance is effected it nullifies the poisonous action by a counteraction.

After what has now been stated no particular assurance is necessary that bacteria and other minute pathogenic organisms do not exercise their injurious effect upon man from an inbred wickedness and pleasure in doing mischief, but that in the phenomena of parasitism we have to do simply with questions of adaptation, with the utilization of situations, so to speak, which man himself provides by his own sins of hygienic omission and commission, and which therefore he himself is able to remove. The germs of putrefaction dispose of the dead bodies of all organisms in nature, simply to satisfy their own need of energy and the conditions of their own metabolism. This is also the case 
when they adapt themselves to the conditions of intestinal putrefaction. They may for the same reason invade the living organism whenever its normal protecting power has become enfeebled through errors in hygiene.

The second question is, Do the so-called "specific" disease germs vary in their capacity to produce disease? Buchner was the first to succeed, upon the basis of systematic experiments, in proving that the so-called anthrax bacilli can be modified artificially in such a way that they are no longer able to bring about any illness, but behave like perfectly harmless saprophytes. The same discovery was soon afterwards made accidentally by Pasteur in regard to the bacteria of the disease called chicken cholera, and we now know from hundreds of experiments that no peculiarity of disease-producing bacteria is more easily affected than the very capacity in question, commonly presumed to be "specific," namely that of producing disease. The physician who seeks the "essence" of the disease in the "specificity" of the disease germs can plainly attach importance only to those parasites whose "specific" capacity of producing disease is invariably exercised. The facts that demonstrate the variability of this capacity therefore obviate all need for seeking an "essence." 
The third question is this: Do the same "specific" disease germs affect all animals with the same typical disease? This question must also be answered in the negative. We see that each kind of disease germ affects only certain hosts; syphilis, leprosy, cholera and typhoid fever are known only in man, while tuberculosis, glanders and anthrax attack both man and certain kinds of animals. Further illustrations are given on p. 243 and in the chapter treating of the individual species of bacteria; others will be brought forward later.

The fourth question is, Does a "specific" disease germ cause only one disease? We may distinguish in this inquiry two groups of phenomena. In the first group belong those facts showing that similar symptoms may be evoked and that the same organs or tissues may suffer anatomically similar changes through the action of entirely different germs. For example, the formation of nodules or tubercles in connective tissue may be brought about by the germs of syphilis, leprosy, glanders, and tuberculosis; suppuration can be caused by the germs of wound erysipelas, the tubercle bacilli, the anthrax bacilli, and the germs of typhoid fever and pneumonia; both the common bacteria of the colon and the chol- 
era bacteria can incite diarrhœa; the bacteria of tuberculosis, of typhoid fever and pneumonia may produce inflammation of the pia mater; tubercle, typhoid, and pneumonia bacteria, gonococci, staphylococci, and streptococci, may cause endocarditis; the phenomena of bloodpoisoning are caused by a whole series of bacteria. In these cases, therefore, the determining cause resides in the tissues and their disposition, not in entirely distinct kinds of bacteria.

The second group of facts, belonging with these but obtained in another way, demonstrate that one and the same "specific" disease germ may produce very different affections. Diphtheria bacilli, for example, may occasion local diphtheria or paralysis or acute blood-poisoning; the bacteria of erysipelas may bring about erysipelas in the skin, but are able also to produce suppuration or inflammation of the lungs; the pneumonia germs may cause typical pneumonia, blood-poisoning, inflammation of the cerebral membranes, or inflammation and suppuration of the middle ear; tubercle bacilli excite tubercle formation in connective tissue, inflammation of the cerebral membranes, suppuration and true consumption or phthisis. The preceding sections contain still other examples. 
Perhaps still a third group might be added, comprising the critical diseases like intermittent fever, relapsing fever and pneumonia. Many observers suppose, in accord with. Henle, that the germs of these diseases in man have a course of development sharply defined by hours or days, and that therefore the life-cycle of the germ determines the cycle of the disease. So far, however, as we know anything about these germs, we never find such remarkable cycles occurring outside of the human body. The pneumonia germs cause crises only in man, while in rabbits they bring about simple bloodpoisoning without any cycle. In cultures they show no regular cyclical character at all. For these reasons I am inclined to seek the basis of such cyclical manifestations in peculiarities of the human organization, and the more so that even in man pneumonia may sometimes occur without crisis and show a resemblance to forms of blood-poisoning. I have already mentioned the conflicting views of Golgi and Laveran respecting malarial fever.

Upon sifting all the available material, I cannot find a fact which is in real harmony with Koch's conception of "specific" disease-germs. I must protest also against the view held by Billroth and Naegeli, which is extreme and one-sided, and I expressly acknowledge that we 
can distinguish species and genera among bacteria and other minute organisms. Such constancy as we observe, however, is not the mystical constancy of "specific" essences, but a constancy made possible by the permanence of the environment. Micro-organisms change with the changes in their surroundings, and the placing of this fact on a sure footing constitutes the great advance that modern bacteriology has made beyond the standpoint reached by Koch.

Just as the human being possessed of a definite organization is compelled continually to adapt himself to changing conditions of life, so is the microbe also constrained to the same task. In the majority of men the bodily constitution is always oscillating, manifesting now increase, now decrease of a definite disposition toward disease. The microbes also vary according to the conditions imposed upon them and display increased or decreased capacity to grow or form poisons in the human body, capacity in other words to remove with greater or less difficulty the resistance inherent in the human organization. Accordingly we observe the occurrence sometimes of mild, sometimes of severe epidemics, and in every epidemic, along with the "typical" cases, we find especially grave or 
especially light cases which do not conform to the schema.

If we diminish the disposition of a man toward a disease we influence his organization in the sense of exalting its resistance to infection. In this way the same effect is produced as when we diminish the "contagious" or toxic quality of the disease germ, the disposition of the man to the disease remaining the same. The ordinary anthrax bacteria, for example, cause in guinea-pigs a generalized blood-poisoning which is speedily fatal, and in dogs, which are naturally immune toward this disease they cause at most an abscess, or a local suppuration. But if we diminish to a certain extent the disease-producing power of the anthrax bacilli, they provoke in the otherwise very susceptible guinea-pig merely a local suppuration, which readily heals.

The disease germs remaining constant, it is possible to heighten natural predisposition to disease by starving animals, or chilling them, or modifying their metabolism unfavorably, as by inducing artificial diabetes. In such cases animals succumb to the very disease germs against which when in a normal healthy condition they are immune. We know also that through hunger, insufficient nutriment, and disorders of metabolism such as diabetes, 
human beings are rendered more easily susceptible to infection than when in a sound and normal condition. Before the days of antiseptics the "healthy skin" played an important part in the progress of a wound.

The "specific" qualities of disease germs, qualities which they possess as do all living things adapted or adapting themselves to definite conditions of life, can only become manifest in the shape of a specific infectious disease when the forms of motion which they impart in order to overcome the resistances arising from the organization of the human body happen to accord with the possibilities of motion which occur in the structure of man as the result of inheritance and adaptation. Only in this way is it possible to account for the fact that-as has been proved concerning some moulds-micro-organisms which, so far as we know, occur only as saprophytes upon dead material are able to produce disease when for the first time,-thus excluding any possibility of an adaptation,- - they are artificially inoculated into susceptible animals.

If the facts are considered in a scientific spirit, rigorously and without prepossession, it is seen that the sum of the qualities of a disease germ is only apparently the "essence" of an infectious disease, that in reality, here as elsewhere, 
a true internal cause is to be found, inherent in the internal organization of man. Just as in all natural processes without exception, so here, the disease germs act as liberating impulses and are able to set free only what in the form of a predisposition toward disease is in some way prefigured both in nature and amount in the human body.

The dependence of either resistance to or disposition to disease upon the conditions of life, as well as a like dependence of the disease germs upon their own conditions of existenceinasmuch as they likewise are living organisms -explains, without recourse to violent assumptions, such facts as that insignificant, local, infectious diseases may become world-wide, as cholera has become in our own century, that new infectious diseases may make their appearance, as for instance cerebro-spinal meningitis in the last hundred years, and that diseases once widely spread like leprosy and the bubonic plague may dwindle almost to the vanishing point. We can easily understand the fact also that, even under conditions originally very different, similar cultural influences arising from similar unsanitary social conditions lead everywhere to the same danger from diseases such as tuberculosis, for the reason that such condi- 
tions create a larger number of the same or similar dispositions toward disease.

That the "specificity" of the disease germs is a phenomenon of adaptation, and hence not an essence is manifest also from the fact that the parasites adapt themselves to given conditions of life not only in their mode of action but in their form. Koch has shown that the anthrax bacteria develop their characteristic form of rods only in their parasitic phase. The tubercle bacilli have such a strongly marked capacity of adaptation that Maffucci and Koch even distinguished as separate species or varieties the germs of mammalian and avian tuberculosis. Fischel and Hueppe, however, by the choice of suitable parasitic and saprophytic conditions of life succeeded in converting each kind, one into the other, and thus in proving that it is the similarity or difference in conditions which ultimately brings about the great divergence.

Finally, in other cases of which accurate studies were made long since, especially among the higher animal and plant parasites, a close adaptation to the conditions of life is manifested in the fact that a parasite, in order to complete its development, needs not only an interchange of parasitic and saprophytic modes of life, like the facultative parasites among bacteria, but 
requires a complete and more or less extensive alternation of generations. Such a parasite, in other words, attacks different animals and plants, one after another, in each of which it passes through a definite stage of development.

Among most parasites there occurs a free or saprophytic stage which is advantageous to the maintenance of the species. In such a case the parasite is often autœcious, that is, no change of host occurs. In alternation of generations there is always change of host or heterœcism, so that in the extreme cases of strongly obligatory parasitism this occurs in a fashion as if saprophytism were altogether omitted. In the tape-worm, for example, we know no free stage; the eggs pass into the outer world but do not develop (at-least up to the present nothing of the sort is known). The scolex of Tania solium is found in hogs, the tape-worm in man; the scolex of Tania mediocanellata is found in cattle, the tapeworm belonging to it in man; the Echinococci are found in man, the respective tape-worm in dogs. The scolex of Bothriocephalus latus is found in predaceous fishes, and the tape-worm in man, but free living embryos arise from the eggs in water. In this latter case, therefore, a limited free stage does occur. In Distomum 
hepaticum three parasitic and two free stages are known.

We know that among the rusts or Uredinea there occur upon grain both summer spores or uredospores (stylospores), and winter spores or telentospores ; out of the latter are formed saprophytically on the fallen leaves a promycelium which develops sporidia; these sporidia get lodgment upon the barberry leaf in which the æcidia develop and form besides spermogonia, the so-called spermatia. We have therefore three or four parasitic forms and one free form. Among the smuts or Ustilaginea the mycelium develops spore-bearing filaments upon the grain; out of these spores a promycelium with sporidia is formed saprophytically; the sporidia may invade young plants and so begin again the parasitic cycle, but they are able also to vegetate saprophytically for countless generations in a torula form. Here two saprophytic forms and one parasitic form are able to exist. The spores of most vegetable parasites are able to develop either a saprophytic form or another parasitic form.

An alternation of generations of just this kind has not yet been demonstrated among disease-producing bacteria and other microbes, but with some species its existence is not wholly improbable. It is obvious that such complica- 
tions increase the difficulty of research, already arduous, but the fundamental facts that have been discussed are not thereby affected or in any way altered. The body of a living organism offers relatively constant conditions, and that explains why, in spite of the complexity due to an alternation of generations in several hosts, the parasites can remain relatively the same.

\section{Infection and Contagion.}

I cannot conclude my examination into the causes of infectious disease without referring to still another feature of the external conditions which may be very important practically. Granting the existence of a given disposition toward disease, disease germs can evidently afford opportunity for the manifestation of this disposition only when they come in contact with it. That is the broad meaning of the word infection. From this point of view, accordingly, an unsuitable condition of the general surroundings of life, such as air, water, soil, and kind of nourishment, may be of importance by virtue of being the means by which the disease germ is first introduced into the body. The quite various channels of the mouth, the lungs, and the skin are available for entrance. The organs affected in an in- 
fectious disease are sometimes in the place where the discase germ enters, sometimes in tissues remote but more disposed toward the disease; the expression locus minime resistentice is used to denote this latter relation.

From this standpoint we classify those diseases as contagious which can be directly communicated by mere contact with the sick and do not need a go-between; and as miasmatic or non-contagious those which are not transmitted directly from the sick but are caused by external agents. In the great majority of infectious diseases both possibilities of communication exist ; one or the other is the more usual merely. In this sense malaria is never naturally contagious, but may be artificially communicated by transfusion of blood; cholera is generally not contagious ; small-pox is always contagious. The concept contagion is accordingly used in a narrower sense than that of infection, and if we depart from this general usage we must always declare the fact and make it abundantly evident. I say this expressly because certain bacteriologists use the term contagion to express the same conception as that implied in the term infection or wound infection. If this is done in the face of usage, of the clinical experience of physicians and of the experience of every layman, then naturally I8 
all diseases must be called contagious, for the word used in this fashion loses completely its peculiar and narrower significance. By some such quibble, for example, Koch and certain of his followers are able to declare cholera to be a contagious disease, while medical experience as well as bacteriological experiments prove plainly that cholera as a rule is not in the strict sense a contagious disease. 


\section{CHAPTER V.}

CAN DISEASE BE CURED BY COMBATING THE CAUSE?

IN the preceding chapter I have attempted to show what it is that we understand scientifically by the expression, the cause of disease. I would lay especial stress upon the idea that disease is always a process resulting from the action of a series of factors of unequal value; these factors may be pictured as acting in an endless chain which it is possible to break asunder at any point. If a link be missing at any point the closing of the chain is made impossible,-the disease cannot be brought about; we are able to avert the disease, which is always our first and most important task. Even if the chain be already closed, the disease already in progress, we may still perhaps succeed in warding off the full effect,-in parting the chain and curing the disease. It results, however, from the unequal value possessed by the separate links of the chain that 
- these have not the same significance before the closing of the chain and afterwards, and that again in the case of different diseases, special differences in the value of individual links may exist.

I choose this comparison in order to make clear at the outset that there can be no curative schema applicable to all cases. The duty of physicians is to treat men suffering from different diseases, not to treat the diseases themselves. Quite apart from the psychological factors which in the exhilaration of exactness are now generally too much neglected, it must be acknowledged that medicine has for a long time shrunk from all questioning about the causes of disease and cure.

The symptoms of disease were; to be sure, considered after a fashion, and then medical practice entered upon a wild and many-sided activity which generally found its outward expression in prescriptions of large doses of some drug for all symptoms, both great and small. A movement counter to this was necessarily provoked. Hahnemann used, for every disease, only one remedy, without reference to the number and succession of symptoms, and observed that better results followed with small quantities of the remedy than with large doses. Then the Viennese school, which Hah- 
nemann still dominated, lapsed into giving nothing at all to the patient, and rested content with observing the course of the malady. With this "do-nothing" method of treatment the outcome was at least as satisfactory as if the patient had been harassed with all sorts of medicine. On the other hand, in certain cases where physicians with their great activity, their many remedies and large doses of medicine had done only harm, Hahn and Priessnitz achieved remarkable cures by using ordinary water, a remedy everywhere accessible. Men gradually learned again to consider the common substrata of life, such as air and food, in their causative aspect, and forty-one years ago Brehmer founded in Görbersdorf a now famous sanitarium where he adduced strong proof in opposition to the conclusions of medical empiricism of thousands of years, that the dreaded disease, lung consumption or tuberculosis, is curable by hygienic measures. Forty-eight years ago Semmelweiss taught that the terrible malady known as puerperal fever which exceeds in fatality even small-pox and cholera, could be prevented by simple cleanliness. These instances, together with Jenner's successful combating of the much dreaded small-pox by means of inoculation with harmless cow-pox virus, constitute good 
reasons for the change of view that has come about. It is evident from our exposition of the causes of disease that there is no special "vital force" and no peculiar " healing power of nature." In healing processes as well as in disease processes we have to deal with things that are both natural and comprehensible.

What, for instance, is meant by the cure of a disease? There are very different things which may lay claim to this title. The cure of tuberculosis by Brehmer's method convinces us that we can actually cure certain diseases by utilizing those phenomena which in the preceding chapter I have instanced as conditions that nature herself furnishes in order to convert a given predisposition toward disease into its opposite, immunity. 'This method makes use of external factors such as air, water and food to influence the organization of man and does not concern itself at a11 with the disease germs, the tubercle bacteria. The human organism is treated with no remedy, no foreign substance. Both prevention and cure of the disease are attained by use of the same hygienic factors. Through this method the natural forces of the organism are strengthened and the organism itself made capable of dealing with its minute invaders. The method produces its effect also by increasing, so to 
speak, the resistance to any pathological discharges of energy.

A cure of another sort is seen when we successfully combat malaria with quinine. Here we introduce into the organism a substance which in certain quantities is a poison: we cast out the devil by the aid of Beelzebub; we take the risk that perhaps we may be introducing so much poison into the body that a disease due to the drug will result. The same thing is true when we treat syphilis successfully with mercury, or rheumatism with the salicylicates. Indeed the reproach of the homœopathist is that with the ordinary large doses of medicme that are given, we do not effect a cure but merely increase the suffering of the patient by superinducing a disease due to the drug. It is, however, noteworthy that under such treatment malaria patients do get free from malaria and become perfectly well, and that the rheumatic patient gets rid of his painful joints and swellings and is able then calmly to discard his salicylicates. There must obviously be something wrong with the homœopathist's explanation.

When bodies like quinine or the salicylicates are used in this way, it is at once assumed by some that such substances act antiseptically, and that their efficiency in the body is due to the 
fact that they destroy the parasites, that they bring about an internal disinfection, so to speak. We know, however, that antiseptics and disinfectants in general are more powerful poisons towards the sensitive body cells than towards parasitic microbes like those that provoke disease. We can speak of a true internal disinfection, accordingly, only when certain substances bear closer chemical relations to certain parasites than to the cells of the body, when, in a word, they act "specifically." It is, in fact, the opinion of physicians that quinine and the salicylicates are "specific" curatives. Quinine is supposed, according to Binz, Behring and some others, to destroy or paralyze the "specific" germs of malaria which ensconce themselves in the red blood-corpuscles in the body. This view is based upon the experimental demonstration that quinine paralyzes these parasites in a drop of blood; the other fact, that quinine paralyzes also the susceptible body cells, the white blood corpuscles, is often not sufficiently taken into consideration, and just as little is the fact regarded that in such quantities as are used in these experiments quinine kills other microbes also. Quinine is an excellent disinfectant for bacteria in the vegetative stage and especially for many different kinds of pathogenic microbes. In a con- 
centration of I : 500-800 it checks the movements not only of malarial parasites, but also, according to Koch, hinders the development of anthrax bacilli, and according to Moczutkowsky, that of the spirillum of relapsing fever, notwithstanding the fact that it does not possess the same specific effect when administered in these latter diseases as in malaria. It must be kept in mind also that the amount of quinine which must be added to a drop of blood in order to destroy the malarial parasite has no special bearing upon the cure of malarial fever. The cure of malaria in man, even when large doses of quinine are given, is accomplished with a quantity of the drug so slight that in experiment it is not sufficient to bring about the paralysis or death of the disease germ.

The question may well be asked, therefore, whether quinine is not efficacious in quite a different way from that commonly supposed; since it neither paralyzes nor kills the parasite. The latter effect would demand relatively large quantities; the cure of malaria can be brought about by small quantities. Now we know that small quantities of a chemical substance can act in a very different way from large quantities. Paracelsus long ago supposed that curatives-arcana, he called them-include substances that destroy the "seed" of disease, 
and others that awaken the "healing power" of nature. Capable physicians, like Van Swieten, Brown and others, recognized after him that the action of small doses differs from that of large doses of the same drug; opium for instance soothes in large doses and stimulates in small. This important empirical fact was for a time almost wholly lost sight of, and only the significance of large doses was appreciated, until Hahnemann attracted attention again to the value of small doses. Even the childish extravagance which found vent in homeopathy could not impair the sound kernel of truth which the doctrine contained. In more recent times accurate investigation along this line has again been carried on by Nothnagel, H. Schulz and Hueppe. It is now evident that we have not to deal with any mystical " potentialization," with the supposed fact that a remedy becomes more potent the more it is diluted, but with a fundamental biological law (cf. p. 9o) which Arndt, H. Schulz and Hueppe first expressed as follows : Every substance which can paralyze or kill any cell or cell protoplasm can also act in small quantities (on the other side of an indifferent point), as a stimulus to cell activity. The absolute quantities leading to such effects are very different with different substances. 
From a consideration of this law, to which there is no exception, and because of a recognition of the important fact that when the cure of malaria is brought about with so-called large doses of quinine the substance is actually pres. ent in the blood in smaller amount than is requisite for the paralysis or destruction of the malarial parasite, some investigators have come to the conclusion that quinine cures because the small doses stimulate the cells of the human body-perhaps those of the blood-and thus effect a "specific" counteraction. Over against the mystical idea of a "specific" stimulus it is to be always remembered that particular stimuli are also general protoplasmic stimuli. Under some circumstances it must happen that not the desired stimulation of the body-cells will take place, but that instead the parasitic cells will be stimulated and consequent harm result. There are indeed cases of malaria in which quinine is injurious even in large doses, and Steudel and Küchel are of opinion that sometimes malarial cases may be directly precipitated by small or medium doses of quinine ; in latent malaria, that is, the quinine given as a preventive acts as a stimulus to the parasites. The latter thereupon react to the stimulus and provoke a case of fever, the quantity of quinine present in the blood being all the time insuf- 
ficient to destroy or harm the germs. In such cases, however, quinine is given only prophylactically and therefore only in small doses; so-called large doses may act in just the same way.

If proper quantities be selected the stimulative effect of small doses must, theoretically at least, be brought into play without any such poisonous effects as might possibly follow from larger doses. 'The cure is consummated without poisoning, without causing a drug disease; it is effected by the intervention of the body cells. The remedy heals simply because it acts as a stimulus and temporarily exalts the natural forces of the organism. Since some cases of malaria may be cured by simple treatment with water, it follows that the malarial parasite as well as some others can be successfully combated by a more simple method of stimulating and strengthening the body-cells.

If the cells of the human body are affected more seriously and in larger numbers by some very severe attack, then stronger stimuli, that is to say larger amounts of the drug, are needed. In such cases the poisonous action of the drug usually becomes manifest also, or it may happen that the stimulus fails to act because it is applied too late and is hence unable to affect many points. The full util- 
ization of simple non-poisonous means of cure needs therefore the use of only small quantities of any remedy and consequently necessitates that treatment should be applied as soon as possible. The same is true of every causal method of healing disease.

The "specificity" of curation by means of a chemical substance may be due to the fact that such a substance acts as a disinfectant only upon certain "species" of microbes or parasites, or it may lie in the fact that such a substance acts as a stimulus upon certain body-cells of the human organism. After what I have set forth in the preceding chapter I need hardly explain that I use the word "specific" in this sense only in a very general way in order to express any degree whatsoever of close relationship between substance and cell. There can here be no question of a strongly specific action in the dynamic sense, of an interchange between molecule and molecule. Chemical substances therefore, that act antiseptically and "specifically" upon parasites may be able to exert such an action not merely upon a single species of parasite; nor have we cause to suppose that they act as a stimulus to only a single set of body cells. At times indeed "specific" substances may even exert a harmful action when given in the "specific" disease. 
If we keep this fact always before our eyes and do not fall straightway into the pit of specificity, as of late infortunately many physicians (and among bacteriologists Behring) have done, the idea of a "specific" curative can do no harm, since by the expression we mean merely a closer degree of mutual relationship and use it simply as a convenient paraphrase.

From clinical and experimental evidence I draw simply the following conclusion: there are chemical substances that can cure disease. We need not abandon the hope of finding new substances which, in this strictly limited sense, act " specifically," and we may at least cherish the hope that such remedies will remove the cause of disease not by their poisonous action, that is by killing bacteria and other parasites, but by acting as stimuli to the cells of the human organism and effecting a cure by "specifically" stimulating the cells set apart for defence.

In those diseases due primarily to the toxic action of bacteria the poison formed might presumably be rendered harmless by means of antidotes or innocuous remedies which serve either to paralyze or neutralize or hinder the action of the poison. The occurrence of a true neutralization of organic poisons of the kind 
under consideration has, however, up to the present not been proved; on the other hand an antidotal action, exerted within certain limits is known to occur, as when, for example, we counteract the effect of a poison that excites the nervous system by one of those poisons which depress nervous activity and in larger quantities paralyze it. The counteraction, like the poisonous action itself, is effected through the intervention of the body-cells. It does not, however, appear altogether impossible to combat even the toxins of infectious disease with chemical antidotes or indifferent chemical substances, if we only free ourselves from unchemical notions about "specificiiy."

The scientific physician is plainly bound to take into consideration everything pertinent to the subject, and must not allow himself to be misled by forms of expression. If on one day there is general agreement among physicians to prescribe no medicine, on the next the disciples of the same school are sure to assail the orthodox physician with the reproach that there was a time when he did not know that healing substances occur in the juice of many plants. Chemistry is now able to separate the important principles of these juices from the unimportant, those with heal- 
ing properties from those with none, and to produce new substances among which curative bodies are to be found. If in these investigations the deplorable error of polypragmaty, or great activity in prescriptions, is avoided, and science and medicine are allowed time for testing the value of these chemical substances, then certainly nothing can be said against the search for "specific curatives" of disease. Unfortunately many errors have been caused in these latter days by a superfluity of recommendations of untried, really valueless and often dangerous remedies, the announcements of which are a source of ridicule to many clinics. Such excesses should not, however, blind us to the theoretically sound basis for investigations of this sort, namely, that chemical substances may be produced analytically or synthetically which are available as curatives or antiseptics against disease. The real foundation for such a belief is easily seen to be the existence of chemical bodies, often very complex, which present, by virtue of their molecular composition, definite possibilities of motion related to analogous conditions in living things. They impinge upon the energetical possibilities of these living things in such a way as to set free energy, whether they do this by acting as stimuli to the man 
or as antiseptics or disinfectants upon the parasites. At present, many physicians, rejecting the good together with the bad, in their condemnation of the extravagances just described, would ban also the sound scientific principle; some of them discard the use of chemical substances altogether, a proceeding which as I should like to prove definitely, has gone too far.

Since it has become clear lately that surgeons, in spite of antisepsis and even in spite of the possibility, as Bergmann expressed it, of disguising gross stupidity under the " mantle of Lister," are beginning once more to be truly modest and that too especially as concerns parasitic processes in the body, the physician also is being compelled to pay attention to various auxiliary factors. Military surgery estimated correctly the true importance of certain general hygienic factors of cure such as fresh air and good food at a time when internal medicine was still far removed from this position. Lately there has been a similar change in the current. For example it is known that in carcinomatous and sarcomatous tumors early operations often prevent the generalization of infection and so far can effect a cure. But it is found also that an operation frequently occasions a general infection in cases 
where without interference the seat of disease would have remained localized and been removed by nature itself. Thus general miliary tuberculosis occasionally follows operations upon tuberculous bones or joints, general septicænia or pyæmia may follow operations upon osteomyelitis, and a general infection may follow incisions in phlegmonous angina and phlegmon. In operations upon malignant carbuncle, generalized anthrax infection which otherwise would not have been forthcoming, sometimes results. Such experiments often bring to us a keen craving to possess, besides the hygienic remedies, "specific" remedies, and to enlarge again the sphere of action of internal medicine, now greatly limited by the surgeon.

Conformably to the law regarding stimulus we may expect to cure sometimes without doing harm even when we make use of chemical substances. But chemicals often show closer relationship to certain tissues or cells than to others, without our being compelled to assume a true specificity, a fitting of molecule to molecule. Add to this that every stimulus acts more intensely upon an accessible tissue which is already over-stimulated and diseased than upon the corresponding sound tissues or cells and it will be seen that for this reason much smaller quantities of medicine are neces- 
sary than when it is a question of killing parasites in the body. If a remedy acts etiologically, however, and attacks the energetical relations obtaining between parasite and host, then it must act upon all phases and the quantity must vary only according to those factors which are manifested externally as symptoms. That is the necessary consequence of a uniform conception of the continuity of causes.

Virchow, in the beginning of his pioneering activity, held another conception. He regarded the single phases of the disease as "essences," considering them from the one-sided point of view of the diseased cells, and held the opinion that the separate phases and symptomis of the disease must be treated quite differently. It is certainly interesting that Henle, Virchow's greatest opponent in etiology and co-creator of the "rational" therapeutics, and who, again in opposition to Virchow, emphasized particularly the physiological factors involved, arrived at the same symptomatological position as concerns the treatment of disease. Virchow himself has never in recent times taken an opportunity to express himself unambiguously on this point, and while his criticism of newlydiscovered phenomena and of tendencies in science has been often dogmatic and frequently 
even captious, we can always understand why many younger physicians adhere to his mode of expression, although it lies more than a generation behind us, and pay too little heed to that development of pathology which has taken place outside of Virchow's sphere of ideas or in opposition to them.

Proceeding in this way, Behring has lately assumed that we can arrive at a uniform causal method of treating and curing disease only by holding fast to Koch's view of the "specificity" of the disease germ, a view already exploded. Such a view of course relegates Virchow's cellular pathology to the background. I hope to have shown that the consistent development of the doctrine of causation upon the firm basis of cellular pathology leads to the same conception as that held by Behring, namely, that a disease can be treated in a uniform way with one substance. By this method of treatment we interfere only with one part of the process and trust to nature herself to obstruct the further action of the disease stimulus.

My conception is less one-sided than that of Behring in so far as that I should not like to forget that a successful treatment can in no wise take into account merely the "specificity" of the disease germ but must consider above 
all else the human organism. Not only the toxin of the disease germ but the human organism itself may be dealt with. Diphtheria, for instance, may perhaps be treated causally and the patient cured without any reference whatever to the bacilli and their poison; this indeed frequently happens in tuberculosis. While Behring would level his weapon only against the diphtheria toxin, Löffler, the discoverer of the diphtheria bacilli and till lately a strong supporter of Koch's dogma of "specificity," maintains that diphtheria can perhaps be cured by destroying the poison-forming bacilli. To keep to my introductory figure, it is possible to consider disease as a process which is carried out like movement in an endless chain. Disease may be cured by influencing this uniform movement in a way which is itself uniform but of varying intensity. It is possible also, always proceeding with an eye to causation, to aim at breaking the chain apart at different points and in that way interrupting the movement.

If we are dealing with slighter and more local affections upon a micro-biological basis, as for example certain catarrhal or inflammatory conditions of the eye or the throat, then we are able by suitable water dressing to increase locally the natural defensive powers of 
the organism which abide in its body fluids, its local tissue cells and wandering cells, in such a way that this simple physical remedy becomes a cure. If the local affection is on the point of becoming general, as is observed at times in so-called catarrhal or rheumatic processes, then we can frequently cut short the whole process by a hot bath. This succeeds because such a physical method, through the intervention of the nerves and by the raising of the body temperature, incites to a temporarily increased activity the same natural protective forces of the body.

By the artificial alteration of those natural conditions the significance of which as curative factors I have previously attempted to indicate, we are able to act more rapidly.although not so durably upon the organization of man, and in such a way as to enable him to battle successfully against the germs of disease. As with chemical remedies, the judgment of a competent physician is necessary here also, since such changes in conditions might lead sometimes to an overtaxing of the organism and thereby do harm instead of good. A scientifically trained physician with hygienic notions and with marked individuality remains always and everywhere the best remedy and the surest means of cure. 


\section{CHAPTER VI.}

IMMUNITY-PROTECTIVE INOCULATIONCURATIVE INOCULATION.

In the preceding chapter I have shown how it is possible to prevent disease or even to cure disease when already in progress by availing ourselves of the same simple hygienic factors which nature herself employs to convert a predisposition to disease into immunity.

Nature uses one remarkable method of transforming a predisposition to disease into immunity, and this method requires special consideration, since for some time it has been utilized also as a means of curing disease. The patient who has successfully passed through certain "specific" infectious diseases has derived some positive gain, inasmuch as he appears protected or immunized against a second attack ; therapeutical and medical interference with disease, on theother hand, recognizes as its highest aim the prevention of harm to the patient, the majority of cures being accompanied with injury. The individual who has "had" 
certain specific diseases rests in perfect confidence that he will not again contract the disease. It is true, the hygienist must acknowledge the fact that this good fortune falls to the lot of only a portion of those who have had the disease, and that even this fraction often gain it at the expense of long illness, loss of work and other injurious consequences. From this point of view it is certainly preferable, considering all things, not to contract infectious diseases at all.

The very old observation that protection against a disease may be acquired by enduring an attack of that disease has led some mothers to adopt the practice of exposing their healthy children to small-pox, scarlet fever and measles, with the expectation that the children when thus exposed intentionally and artificially to the infection will contract the disease in a milder form than the more susceptible children who have previously sickened in a natural way, but that the children thus deliberately infected will gain the same amount of protection as the others. Thucydides recommended that those who had recovered from the plague at Athens, and had thereby acquired protection, should be employed in the care of the sick. In India and China the custom of blowing into the nostrils dried and pulverized 
material from small-pox pustules was resorted to for the purpose of obtaining protective inoculation, and, later, in the Orient, the method of inoculating pustule scabs beneath the skin came into vogue. This latter method, the socalled practice of variolation was introduced from Constantinople into Western Europe by Lady Mary Wortley Montague between I7I7 and I72I. European physicians learned the art so well that only an inconsiderable proportion of those treated died of the artificial smallpox inoculation while an enormous number of men ordinarily perished with natural smallpox. Those individuals who passed through the artificially induced small-pox were almost as well protected against the disease as those who had at much greater peril overcome the natural contagion.

It was observed at a later date by herdsmen and milk-maids in both England and Schleswig-Holstein that cows occasionally developed on the udder an eruption resembling smallpox, and that this was communicated to the persons engaged in milking. Those who had been thus infected with "original" cow-pox, which at first was regarded as a peculiar disease, were often protected just as well during epidemics of true small-pox as those who had had the small-pox. These observations were 
confirmed by Fewster and Sutton in London in I768. The landowner Jesty in 1774 first intentionally inoculated himself and his family with cow-pox for the purpose of gaining protection against small-pox. A Holstein teacher, one Pless, and above all the English surgeon Jenner developed the method systematically. They inoculated persons first with the cow-pox, then with genuine small-pox, and observed that in these cases the inoculation with smallpox material no longer produced any effect. In order to do away with the danger, for danger was never wholly absent since some persons died in consequence of the artificial small-pox inoculation, and especially to put a stop to the spread and maintenance of the small-pox contagion by these artificial-inoculations, Jenner, after thirty years of experiment, introduced the practice of systematic inoculation with the supposedly independent virus of cowpox. This is the method of vaccination as opposed to that of variolation. The fourteenth of May, r796, is regarded as the day of the first official inoculation with vaccine, and hence the century jubilee of this great hygienic achievement has been lately celebrated. The protection conferred by vaccination was not so effective and did not last so long as that afforded by artificially induced small-pox or by a natural 
recovery from the disease, but the method always protected many individuals and the protection lasted for a long time.

As far back as I839 Thiele proved that the supposedly peculiar and independent disease of cow-pox was nothing other than true human small-pox which had been so weakened by passing through the organism of the cow that it behaved in human inoculations not like human small-pox, but like cow-pox. Ceely in I84 I produced cow-pox in cows by inoculation with human small-pox. A decade later Bollinger and Stamm first accurately established the fact that there is no separate disease of cowpox (a statement that must, to be sure, be corrected in so far as that vesicular eruptions sometimes occur on the cow's udder which represent a peculiar disease of bacterial origin, similar to the cow-pox, but not conferring protection against sma11-pox). Stamm in his citation of one case drew attention to the possibility that cow-pox, in being carried over to man, might again become malignant and indeed even like the original small-pox. The very practice of vaccination might keep small-pox alive in the land and did not tend to extinguish it, since the human race could not cope naturally with the disease as it could with the plague and leprosy. Since Stamm became eventually 
a fanatical opponent of vaccination the things he really accomplished were disregarded. His work contained nevertheless a sound kernel which, together with the facts previously discovered by Jenner and Thiele, included many things in the way of practical experiment and simple observation of nature. Later all this ground had to be experimentally won anew.

Isopathic or Specific Inoculation With Living Parasites-Attenuation of Disease-producing Bacteria.

This new principle is connected with the name of Pasteur, who in I880 observed that the parasites of chicken cholera, a malignant disease of the domestic fowl, related to the swine-pest, could by artificial treatment be made to suffer such loss of virulence that the animals inoculated became affected only locally and did not experience a general and fatal infection. The animals after being affected in this way only at the place of inoculation could subsequently be inoculated with the virulent parasite without fatal results ; they were protected against the disease by the preliminary inoculation with the weakened virus. In a similar way, by attenuating various microbes, such as the bacteria of anthrax, of symptomatic anthrax and of swine erysipelas the attempt 
was made to secure protective virus (vaccines, lymphs) which should affect the animals but slightly and yet protect them against a subsequent infection from either artificial or natural sources.

In 1884 Ferran $^{\mathrm{r}}$ first protected guinea-pigs against fatal doses of the cholera bacteria by subcutaneous inoculation with the same germs. After Gamaleia had discovered a method by which comma bacilli of constant and high virulence could be obtained, W. M. Haffkine cultivated two varieties of different degrees of virulence and with these he carried out in India in $1893-94$ protective inoculation against cholera, although with slight success. ${ }^{2}$

Diminution of the virulence of bacteria is especially effected by cultivation with abundant access of air, at times in connection with access of light-conditions the significance of which in the removal of virulence has already been mentioned on p. 56,- by cultivation at high temperatures (p. 66), and by the addition of chemical substances (p. 90). Sometimes it is advantageous to proceed with the attenuation in definite stages in order to obtain virus of different degrees of strength. In the case of

${ }^{1}$ Compt. rend. de l'Acad. des sciences, CI., I 885.

2 At the present date Haffkine's results as a whole must be looked upon as distinctly encouraging. E. O. J. 
anthrax, for example, we adopt the plan of inoculating the animals first with a weaker then with a stronger virus and testing the immunity thus obtained by inoculation with a fully virulent material. It was next discovered that animals which, according to Pasteur, were vaccinated securely against wound anthrax, nevertheless, according to Koch, succumbed to intestinal anthrax, and that therefore artificial immunization does not always protect against natural infection. Quite satisfactory results, however, are obtained in both anthrax and swine-erysipelas, and particularly in the disease of cattle known as symptomatic anthrax in districts in which the diseases in question are very prevalent. In the latter disease a protective inoculation is generally made spores weakened by steam being used (Kitt). According to the method employed for attenuation the less virulent varieties may be degenerate, not growing well in cultures; or they may have simply become less parasitic, that is to say, more saprophytic, and grow even more lustily than the parasitic parent form (they may have become, that is to say, varieties or modifications of species, such as occur for instance in the sweet and bitter almonds, in the hemlocks with or without conine, in the cinnamon trees with or without aromatic bark). 
Another method of attenuation based in this case upon utilization of the living animal body was also first used by Pasteur. ' If the bacteria of swine-erysipelas are transferred from swine, in which they possess a definite degree of virulence, to pigeons, and thence again to fresh pigeons, they acquire in the course of this transfer a heightening of their virulence. Conversely, a diminution of virulence is brought about by transfer from rabbit to rabbit. By use of the bacteria which have become weakened in their passage through the body of the rabbit it is possible to protect against that degree of virulence shown in spontaneous swine-erysipelas; or it is even possible to go a step farther and heighten the artificial immunity so that it protects against the germ whose virulence has been increased artificially by passage through the body of the pigeon.

Pasteur discovered a similar thing in rabies. The virus,- - from which a definite microbe has not yet been isolated,-becomes weaker (the degree of virulence shown in rabid dogs being designated as "street-virus") by passage through the ape, stronger by passage through the rabbit. Pasteur made use of the spinal cord of rabbits in which virulence had been exalted to the highest point, and called this strongest obtainable virus "virus fixe." In 
the production of the desired degree of virulence the spinal cord is dried in air free from water and carbonic acid; by that means the virus is weakened. The duration of the process of attenuation determines the amount of decrease in virulence. If animals are inoculated with the weakest material and then with a slightly stronger, and so on, it becomes possible eventually to inoculate safely with the fresh and most virulent cord of a rabbit. The animals thus vaccinated no longer die from rabies; they have even become immune to a more virulent rabic virus than is likely to occur in nature.

In all these cases, cultures or viruses were used which, though attenuated, were still active, but in I887 Hueppe discovered in the case of chicken cholera and Wildseuche, and Chauveau in I889 in the case of anthrax that even cultures altogether attenuated, which had become purely saprophytic and no longer excited any sort of pathogenic action could nevertheless confer immunity against virulent cultures.

In all the inoculations hitherto described the material used in inoculation, however obtained, and whatever degree of attenuation it might possess, was identical in kind with the infective substance. Protective inoculation would seem 
from this to be strictly "specific," or still more precisely expressed, "isopathic."

Still another step was taken in the same direction. The experiments described above were carried out with living microbes. Even when attenuated cultures were used it sometimes happened that some of the inoculated animals died either through accidental inoculation of too large amounts of material or through greater individual predisposition to disease, thus affording direct proof that attenuated material might, by passing through suitable animals, again become virulent. The attempt was made therefore to dispense altogether with the living parasites and their attenuated modifications.

Inoculation With Metabolic Products-Protective Substances and Poisons-Immunity Does Not Depend Upon Habituation to Poison.

Panum in 1874 first established the fact that the poisonous action of bacteria is due to soluble poisons formed by the bacteria, but separable from them, and that this poisonous action could be advantageously combated indirectly, namely, by combating the germs forming the poison. It was afterwards discovered by Koch in 1878 , by Chauveau in 1880 , and later by many other observers that a number of pathogenic germs actually injure the organism less 
by their proliferation in the body than by the formation of soluble poisons, which are absorbed, pass into the circulation and so affect important tissues like the nerves, muscles or glands. It was shown to be possible, by separating the poisons from the bacteria by filtration or by killing the bacteria by means of chemicals or heat, to produce with these poisons manifestations of disease that appeared to resemble those which earlier had been produced only with the living bacteria. These poisons were at first, in accordance with Brieger's view, held to be organic bases, the so-called ptomaïns. Later it was seen that the bacterial poisons were poisonous proteid bodies or substances closely related to proteids or at least not positively separable from them, and that they often possessed properties similar to those of the digestive ferments (p. I25).

The French investigators Toussaint and Chauveau as far back as I880 endeavored to establish the theory, in opposition to Pasteur's view, that the protective effect resulting from the incorporation into the body of attenuated disease germs depends upon the fact that the soluble metabolic products of the germs confer immunity. The American investigators Salmon and Smith finally proved, in I886, that this is sometimes the case, by successfully 
using poisonous "metabolic products" to protect against the virulent disease called American swine-plague. Such soluble substances, it was hoped, could be measured accurately and then safely introduced into the body in definite quantities. With substances of this kind, freed from germs by heating or by filtration, Foa and Bonome produced immunity against Proteus; Charrin against Pyocyaneus, Roux and Chamberland against maligant œdema, Roux against symptomatic anthrax, Gamaleia against the Vibrio septicæmia of pigeons and against cholera, and C. Fränkel against diphtheria.

It might seem safe to infer from these facts that immunity consists in accustoming the organism to the "specific" poisons of the disease germs. Such a conclusion, however, is not in harmony with the observations previously mentioned as made by me in 1887 and by Chauveau in I889, for we succeeded by the use of entirely attenuated bacteria, which had become wholly saprophytic and no longer capable of forming specific poisons, in producing immunity towards these same bacteria in a fully virulent condition. Hueppe and Wood succeeded also in 1889 in producing immunity towards disease-producing bacteria by inoculation with ordinary saprophytes derived from water 
and soil; immunity towards anthrax was obtained in this way and the first harmless protective inoculation thereby effected.

The conviction became general, moreover, that many of the methods employed to separate the "specific" poisons from the parasites forming them destroyed or altered the so-called "specific" poisons, and it was seen that immunity was still obtained with the metabolic products. In fact, if only the poisons themselves were introduced, immunity did not result, as Roger and Charrin discovered before in working with Pyocyaneus, C. Fränkel with diphtheria, and Hueppe with chicken cholera. Guided by these facts, Gamaleia and Hueppe, and afterwards H. Buchner, were led to the discovery that the "specific" poisonous substances found outside the parasites in the culture fluids, were not identical with the protective substances occurring in the disease germs or their metabolic products.

By these discoveries along the line of "specific" immunization it was established that: I, Undergoing the disease, 2, Inoculation with attenuated germs, 3, Inoculation with disease germs which have become wholly impotent, 4, Inoculation with saprophytes, and 5, Inoculation with the metabolic products of the parasite, can all confer immunity while; 6, Inocu- 
lation with the specific poisons effects no immunization.

It was next proved by various series of experiments that completely attenuated bacteria can not as a matter of fact any longer form the "specific" poison. Following out this clue the attempt was made to deprive virulent cultures of their poison. The bacterial poisons have, as mentioned on p. I24, the character of active proteid bodies, and in a moist condition they are very sensitive to high temperatures. If the fluids containing the poisons be warmed to about $55^{\circ}-65^{\circ}$ they become for the most part inactive and lose their poisonous qualities. As Hueppe has discovered for chicken cholera and Asiatic cholera, Brieger and C. Fränkel for diphtheria, F. and G. Klemperer for pneumonia infection in rabbits, Brieger, Kitasato and Wassermann for cholera, diphtheria, typhoid fever and swine-erysipelas, immunity can be obtained by the use of cultures devoid of poison. The explanation of this kind of immunity is that the bacteria are prevented from growing and forming their poisons in the body ; they are destroyed just as saprophytes are, and the organism of man or of the lower animals is in consequence not subjected to a contest with the bacterial toxins.

We are still in the dark as to the nature of 
the protecting substances. That they are integral elements of the living protoplasm of the bacterial cell appears certain ; they are supposed to possess a higher phosphorus content than the toxin, and they pass with greater difficulty through porcelain filters. We must infer from the protective action of impotent cultures, that these substances are the expression of the more immutable qualities of the species, and not, like the poisons, of the variable characteristics. It may be legitimately conjectured that foreign protoplasm and active proteid are usually able to confer some sort of immunity although in varying degrees according to nature and origin.

If experiments are made with proteid-like poisons of diverse origin (with the vegetable poisons abrin and ricin, as Ehrlich has done, and as Roux, Behring and Tizzoni have done in a similar way with tetanus and diphtheria poisons), it is seen that the animal organism comports itself toward these poisons just as toward arsenic, alcohol, nicotine or morphine. The organism accustoms itself to increasing quantities of the specific poison, and becomes tolerant of it, but is not affected to the extent of acquiring immunity, and is not, properly speaking, immunized. If true immunity be obtained with " metabolic products," bodies 
must be present in these products which act unlike the poisons.

To put it briefly, the protecting bodies are either the bacterial cells themselves, or they exist in the cell-body, or they become separated externally from the cells. In the so-called metabolic products present in culture fluids after bacterial growth are found not only the true toxins but always along with these the dead bodies of the bacteria, together with the dissolved portions of dead bacteria and the soluble cell substances that have separated from the bacteria during life. In the active culture fluids, not only the poisons, but cell substances of another kind are present in solution, and both of these may be separated by filtration from the living or dead bacterial cells. If culture fluids in which active parasites have grown be heated to about $70^{\circ}$ the "specific" poisons are destroyed or changed, altlough at this temperature the soluble cell substances which confer immunity appear to suffer no essential alteration. But not only those parasites which are attenuated and form little poison and those that have become impotent and no longer form poison, but also certain harmless saprophytes which form no poison at all, possess such soluble protective cell substances. It is very improbable that the protecting substances are 
nothing but the poisons modified by heating, as some investigators have asserted. The formation of both protective substance and poison appears to be a "specific" activity of certain species of micro-parasites. The attenuation of disease-producing bacteria depends accordingly upon the fact that the capacity for forming poisons is diminished while other cell activities are not essentially influenced.

\section{Proteids.}

Those proteid bodies which are obtained by boiling bacterial cultures with and without addition of potash lye or of glycerine are certainly not the substances that bestow protection. Whether the proteids obtained by this method are produced from the real protective substances by the high temperature is still uncertain. H. Buchner discovered that such proteids provoke aseptic fever and inflammation, and Husppe and Scholl found also that they act in characteristic ways, and cause leucocytosis or local suppuration. Prudden and Hodenpyl found that they act as a formative stimulus to the body cells and Gärtner and Römer that they bring about lymph secretion. In this category belong such substances as the "tuberculin" obtained by Koch from tubercle bacteria and the "mallein," obtained from cul- 
tures of the glanders bacillus. These proteids confer no specific immunity and no specific tolerance of poison ; they are neither the specific protective substances nor the specific poisons of the bacteria. According to Koch it is possible to accustom the body to the presence of large quantities of these proteids. They bring about a reaction of the body cells and tissues by exciting an inflammation which enables the organism to defend itself from the invading parasites. In rare cases a cure of tuberculosis can perhaps be effected by tuberculin, but, as is well known, the expectation of a "specific" cure has not been fulfilled. The inflammatory reaction, with the resulting increase of temperature which follows the injection of tuberculous animals with tuberculin may reveal the existence of an internal seat of disease. This method of using tuberculin has been widely introduced for the diagnosis of the disease of cattle known as "pearly disease," and mallein likewise is frequently used with success to obtain an early diagnosis of glanders. It must however be mentioned that sometimes the reaction is not forthcoming, and other processes often intervene for the simple reason that the proteids are not specific in the ordinary sense of the word. Indeed, according to Weichselbaum, Ortner and Klein, tuberculin has no effect at all upon uncompli- 
cated human tuberculosis, but does bring about a reaction in the case of mixed infections occurring in the form of inflammation of the lungs by stimulating the pneumonically infiltrated parts. According to Römer it is possible to employ in the place of tuberculin and also of mallein the proteids produced by many different kinds of bacteria. Certain proteids, therefore, act as powerful stimuli and in such a way that active proteid bodies of a kind to be mentioned presently, and which are possessed of bactericidal and antitoxic power, make their appearance in the blood in greater abundance than before; such proteids are not themselves the specific protecting substances.

In this discussion it is of practical advantage to distinguish between natural resistance or immunity, acquired immunity (gained either naturally or artificially) and the habituation to or tolerance of poison. In natural immunity microbes and parasites can not invade the body of the organism ; the body possesses the power of destroying the parasites and their poisons. In specifically acquired immunity the body has gained the power of preventing the invasion of certain definite parasites and their formation of poison, although before the acquisition of this property these germs were able to enter the body and do harm. In a state of 
habituation to poison the body has acquired merely the power of "paralyzing" the specific poison, although the parasite may perhaps still be able to grow in the body; the latter event, however, is no longer of moment because any poison formed is rendered innocuous. In both natural and acquired immunity the body disposes of a quantity of poison equal to that formed in the course of a natural or artificial infection, while by gaining an habituation to poison, the body becomes accustomed to very much larger quantities. The body, then, may acquire the power to cope with poisons, or the power naturally existing may be heightened, in a manner differing, at least quantitatively, from that shown in natural resistance and acquired immunity: for example, according to Behring, an animal may not be tolerant of tetanus toxin although displaying immunity to the disease, or, conversely, the animal may be susceptible to the toxin at a time when its blood-serum is to the very highest degree antagonistic to it. In hydrophobia both the poisonous action and the immunizing power are associated with the central nervous system and inoculation with material from this source can produce immunity even when the material no longer acts poisonously. By inoculation with "metabolic products " the body acquires immunity to the dis- 
ease as well as tolerance of the poisons ; hence stress must be laid sometimes upon one, sometimes upon the other process according to the mode of action of the parasite.

In diseases such as tetanus and diphtheria which are due less to the multiplication of bacteria than to the action of their toxins it is perhaps better to immunize not with attenuated, but, according to Behring's method, with fully virulent or hyper-virulent cultures since what we endeavor in the first instance to obtain by immunization is merely a form of habituation to poison. This method of procedure, however, is not necessary. As mentioned above, Fränkel was able to produce immunity against virulent diphtheria bacteria by the use of cultures deprived of their toxin, the explanation being simply that the immunized organism, in preventing the growth of the bacteria, thereby prevents the formation of poison, so that habituation to the poison itself becomes unnecessary.

Protective Serum-Active and Passive Immunity-Tissue Immunity and Antitoxin Immunity.

There is still another and entirely different method of specific immunization. In I884 Ferran used subcutaneous injections of the 
blood-serum of cholera patients for the purpose both of curing patients suffering with cholera and of protecting healthy individuals from its attack, but it is not clear what his theory of the proceeding was. Héricourt and Richet in I888 inoculated dogs with pyæmiastaphylococci, and the dogs developed local abscesses. When the serum of such dogs, after healing was accomplished, was conveyed to rabbits-animals which otherwise would have rapidly succumbed to infection with the disease-all of the rabbits were found to be protected, whereas the serum of healthy uninoculated dogs protected the rabbits only in a fraction of the cases. The serum of healthy dogs exerted a certain influence, but the serum of those dogs which had endured the definite affection possessed much more perfectly the power of imparting immunity to the disease. The quantitative difference in this case at least was in favor of the preliminary "specific" immunization.

Babes and Lepp discovered in I889 that the serum of dogs immunized against hydrophobia protected other dogs against the disease. More important was the discovery of Behring and Kitasato in I89o, that the blood and bloodserum of animals that had been immunized against tetanus and diphtheria conferred upon 
susceptible animals immunity to the diseases in question and therefore apparently acted qualitatively or isopathically. Ehrlich showed that the milk of immunized animals exerted the same effect. Immunity obtained by the use of the serum was somewhat transient as compared with immunity acquired by means of inoculation with the living parasites or their metabolic products, and as compared with the acquired habituation to poison : it lasted only a short time, but on the other hand it made its appearance very quickly. It was, so to speak, "passive," while the other was "active." This difference between active and passive immunity, which apparently cannot be bridged over, may be illustrated by the following examples:

If sheep are endowed with àn active and durable immunity against cutaneous anthrax, they will nevertheless succumb to intestinal anthrax, as Koch has proved. If rabbits are inoculated with rabbit septicæmia in one ear or on the cornea of one eye, a subsequent infection on the same side of the body no longer takes effect; but, according to Löffler, the animals still succumb to infection of the ear or cornea on the other side, and it is only after some time that a general immunity of the whole organism can be remarked. According to Pastenr, rabbits which are protected against hydrophobia 
arising from skin infection or from wounds, succumb if the virus be inoculated directly into the brain. According to experiments by Hueppe and Salus, if fowls be inoculated in a pectoral muscle with the bacteria of chicken cholera, or pigeons be inoculated in the same way with the germ of human cholera, the birds can not afterwards be successfully infected on the same side of the body, although an infection of the pectoral muscle on the other side is still effective; then ensues a stage where even this mode of inoculation no longer succeeds, but where direct inoculation into the blood current still suffices to cause death. Guinea-pigs which have been securely immunized against cholera infection by way of the peritoneum succumb, just as readily as if nothing had happened, to infection through the stomach.

Protective inoculation requires time, for the simple reason that the protective substances must act as liberating or exciting stimuli upon definite tissue-cells of the body. This kind of immunity is acquired only through the intervention of the body-cells ; active immunity is an immunity of cells or tissues. The same thing holds good of the habituation to or tolerance of poisons. "Active" immunity of the sort obtained through the influence of the 
body-cells, and, although in somewhat slighter degree, "active" tolerance of poisons, can persist for months and even for years, because these conditions do not depend upon the transient bacterial invasion, but upon the acquired properties of the body-cells. The body-cells, because of their relatively great independence of varying conditions of nutrition, are able to cling to their inherited or acquired characteristics. For this reason they render more permanent the qualities of the blood and other body-fluids which maintain an interchange of substances with them.

Without this intervention of the cells the body-fluids very quickly rid themselves of foreign substances either by excretion through intestine, stomach, kidneys or skin, or by oxidation or by chemical combination. New and lasting characteristics are not acquired or preserved by the body-fluids alone. It is the organism of the host,-the cellular tissue of the human being,-that reacts towards the stimulus of those bacteria or bacterial proteids or toxins with which we endeavor to heighten the resistance towards parasites or parasitic poisons. Bacteriology affords powerful support to cellular pathology, a fact that can not be urged too strongly against Behring's view.

In the case of " passive" vaccination, or the 
antitoxin-immunity obtained with serum, animals seem to be immunized so quickly that any participation of the body-cells in the process appears to be out of the question. Protective substances are apparently introduced directly with the serum; they must therefore act almost immediately, and like all foreign substances are also soon eliminated. Let us seek to discover therefore the nature of these hypothetical substances that are contained in the protective serum.

When Ehrlich rendered animals immune towards two proteid-like poisons of vegetable origin, abrin from the jequirity-bean (Indian licorice, Abrus pracatorius) and ricin from the castor-oil bean, tolerance of these respective poisons seemed to consist in the fact that the immune animals possessed in their serum a kind of antidote, antitoxin, or "anti-substance" (Antikörper) as Ehrlich somewhat singularly expressed it. These substances, which are themselves proteid-like, were supposed to paralyze the proteid-like poison, or, as Behring conceived, to neutralize it. The difference between active and passive immunization, between tissue immunity and antitoxin immunity, consists, then, in the fact that in active immunity the organism inoculated forms this antitoxin but slowly and with the help of its 
cells, which, however, can continue for a long time to produce the antitoxin. "Passive" immunity differs in the respect that these "antisubstances" are introduced into the body all cut and dried, as it were. In the latter case the animal treated with serum experiences the benefit of the antidote without on its side bearing any of the burden of preparation, while the animal alone that affords the protective serum assumes actively the dangerous responsibility of forming the antidote. In passive immunization the cells of the secondarily protected animal contribute nothing to the acquisition of immunity, and consequently the antidote incorporated in its body remains like a foreign proteid ; the cells eliminate this strange proteid as quickly as possible. It is for this reason that passive immunity is not lasting.

As Behring's conception has grown in favor, Ferran's experiments upon cholera have been unwittingly taken up again; immunity against cholera has been brought about by the use of the serum of cholera patients. G. Klemperer, Lazarus and Metschnikoff found that this serum, varying it is true in an extraordinary way, and often not having any effect at all, usually protected guinea-pigs against an infection of cholera bacteria which otherwise would have been fatal (protection was often im- 
parted by the use of so small a quantity as o.oIcc.). This protection was positive against intraperitoneal infection, less sure against infection by the stomach, and not effective at all against the cholera toxin. R. Pfeiffer now tests for the presence of immunity by using a culture obtained from the last epidemic and which he regards as a typical cholera culture. He conceives that this method is available for determining whether cultures of comma bacilli are "true" cholera bacteria and for distinguishing them sharply and without fail from other comma bacilli. The method in brief is this : a guinea-pig is infected with the culture of comma bacilli the nature of which it is desired to determine; if the anti-substances produced in the serum of this animal are able to protect against inoculation with the test culture, then the culture in question is true cholera; if it is not capable of protecting against infection with the test culture, the germs are considered not to be cholera bacteria. This test or standard is however quite indefensible, since it takes for granted the very thing to be proved. I obtained in Hamburg several cultures from severe cholera cases that occurred in this very epidemic of I892, and which culturally were absolutely alike; yet the serum obtained through inoculation failed to produce reciprocal immunity. 
At the time of this epidemic a culture of a comma bacillus was obtained from the Nordhafen in Berlin which agreed in all respects with Koch's comma bacteria, and on this basis the river Spree was officially declared to be "infected"; afterwards this species was found not to respond to Pfeiffer's reaction, and so could no longer be regarded as a cholera germ. Inoculation with the Finthen cholera germ did not yield me a serum that would protect against the cholera bacteria of Hamburg. R. Pfeiffer himself did not obtain from the Massowah cholera germ a serum that would protect against his test culture, although this Massowah culture was obtained in the course of a severe cholera epidemic of Indian origin which had furnished us with orie of our most virulent cholera cultures; and a culture of this same germ had caused a severe case of laboratory cholera in Italy! Rumpel in I893 obtained two cultures of comma bacilli from cholera cases that had ended fatally and these when non-luminous, protected against Pfeiffer's test-culture, but if employed at a time when they were phosphorescent afforded no protecting serum. Rueteand Enoch found finally that inoculation with a culture of the Finkler-Prior comma bacillus afforded serum that would protect against Pfeiffer's test-culture. 
The principle of specificity as exemplified in the setting up of "true" species of bacteria can evidently be carried to such an excess as to lead eventually to scientific absurdities. The error made by R. Pfeiffer is due to the fact that in consequence of the post hoc, ergo propter hoc fallacy, he conceived that immunization was bronght about by the antitoxin.

Ehrlich was the first to attempt to measure the efficacy of the toxins. Such a calculation appears somewhat more exact than it really is because the outcome of an attempt to establish the degree of toxicity of a substance depends upon the animal subjected to experiment, and the animal, for the reason that it is a living organism, often reacts more delicately than a balance to be sure, but never so precisely. The process of determining the strength of a dose is as follows. The minimal fatal dose of the poison is first determined; for instance diphtheria cultures may be obtained, o.Icc. of which is sufficient to kill a guinea-pig of 500 grams weight inside of $24-48$ hours, and tetanus cultures, $0.002 c c$, of which can kill a guinea-pig, the solid poison being estimated to be more potent than strychnine or even prussic acid. Such a degree of immunity as may be gained by an animal through protective inoculation enables it to withstand many times the 
minimal fatal dose, and injection of the minimal fatal dose itself is now borne without reaction.

Behring and Ehrlich made the estimation outside of the animal body by mixing a definite quantity of the toxic solution obtained from cultures with graduated quantities of the protective serum. In this way mixtures of varying grades of action are obtained, first those that manifest unmistakable toxic action, next those by which the course of the disease is retarded, then those in which only local phenomena make their appearance, and finally those in which the quantity of serum injected at the same time with the toxin completely inhibits the action of the latter. A serum o.Icc of which renders entirely impotent ten times the minimal lethal dose is termed normal serum One cubic centimeter of this normal serum is called an immunization unit. If O.OIcc. of a serum confers protection, the serum would possess ten immunization units.

Roux's method of calculation starts with the living animal. He computes the body weight of the animal which is protected against the minimal lethal dose by a unit volume of serum. He employs Icc. of a toxin solution, o.Icc. of which kills a guinea-pig of 500 grams in 24 hours; this starting-point, therefore, is the same as that of Behring and Ehrlich. If Icc. 
of this toxin solution is nullified by $0.05 \mathrm{cc}$. of a serum, on simultaneous injection, Icc. of the serum evidently protects IOO,OOo grams of animal against the minimal dose, and the inmunizing value is hence, according to Roux, I00,000. With very potent serum, infinitesimal quantities are sufficient to produce immunity; in diphtheria about $\frac{1}{100,000}$ of the body weight and in tetanus about one-trillionth can protect the animal.

\section{The Nature of Antitoxin.}

These facts must not cause us to mistake the action of antitoxin for a neutralization, a direct nullifying of the poison by the antidote in the sense of a molecular interchange such as occurs between acid and alkali, although such a comparison has been used by Behring. The action of antitoxin, so far as at present known, is simply that of a cell stimulus. We are even able to prove directly that the protective serum, or the supposititious antidote in it, does not actually destroy or neutralize the poison used in immunizing or in establishing a tolerance of poison, but that both bodies can exist side by side.

Buchner prepared a mixture of tetanus toxin and serum which was neutral in the Behring- 
Ehrlich sense, and, upon injection of the mixture into white mice no influence of the toxin was to be noted. Had it been a real neutralization we should expect that a correspondingly large quantity of this mixture would have had no effect upon other animals. When the mixture was inoculated into guinea-pigs, however, signs of tetanus poisoning made their appearance. In reality, therefore, toxin and antitoxin could not have acted directly one upon another, but both substances must have exerted their effect in the animal organism side by side. A partial nullification and prevention of the toxic action does appear, to be sure, in such cases, but I was able to bring about the same result by mixing enzymes with the toxin. A mixture of canine serum and rabbit serum acts less powerfully upon the typhoid bacteria than does either serum by itself (Buchner). One kind of active proteid body, therefore, seems to act to some extent upon another, but this action is not always sufficient to destroy the toxic power of a mixture, and on the other hand an antagonistic action of this sort is not usually specific, but is wholly general in character; for, according to Behring, it is possible to diminish the toxic power of the culture fluids with use of iodine terchloride, and even, according to Vaillard, with simple iodine. 
Roux and Vaillard found that a mixture of tetanus toxin and tetanus antitoxin which was wholly without effect upon healthy animals, caused tetanus in animals of the same species which had previously suffered from other diseases and thereby become weakened. They discovered also that healthy animals which had supported inoculation with the mixture apparently without any effect, subsequently developed tetanus when inoculated later with the products of other bacteria; at least part of the toxin had remained in the body of the animal for several days without producing any effect, but also without being destroyed.

Calmette, Phisalix and Bertrand found that snake-venom, abrin and ricin are destroyed by heat less easily than are the respective antidotes found in the serum after the establishment of a tolerance of these poisons. If a mixture of one of these toxins and its antidote be heated, the antidote is the first to be destroyed, the poison remaining behind. By heating such mixtures to $68^{\circ}-70^{\circ}$ these observers demonstrated that the poisons persist in spite of the treatment, and therefore can not have been neutralized or destroyed by the antidotes. On the other hand, when a mixture of the diphtheria toxin and its antidotal serum is heated to $68^{\circ}$ the toxin is destroyed first and 
the strength of the antidotal element is merely weakened.

We may now ask what are these "specific" anti-substances found in the blood after the establishment of a "specific" habituation to certain poisons? They are, so far as we can judge, different from the real bacterial poisons, from the alexins or defensive proteids of the blood and from the ferments, since in contrast to the toxins they are able in general to withstand higher temperatures, and greater exposure to insolation and putrefaction without becoming impotent. Even if they possess the same degree of resistance or are less resistant (as is anti-abrin compared with abrin), they differ in other respects. So long as the "specific" protective inoculations are alone considered, the participation of the bacteria must be regarded as the sole or essential determining factor in the production of these substances.

Two interesting observations upon man also favor the view that bacteria take part in the formation of the anti-substances. Buschke, after he had infected himself with material suspected of harboring tetanus virus, used a prophylactic injection of tetanus serum and observed that tetanus-like symptoms ensued. Bearing in mind the great susceptibility of man 
to tetanus it would seem from this as if some component derived from the tetanus bacteria were present along with the anti-substances. Similarly Marcuse observed in a child after the injection of diphtheria serum the appearance of paralysis of just such a character as would be produced by diphtheria toxin.

But on the other hand an important fact lends countenance to the view that the cells of the human or animal organism which forms the anti-substance are the more important factors. If we administer a given quantity of toxin in the form of many small doses one after another, and in another instance inject the same quantity all at once in one large dose, the amount of antitoxin found in the animal after the same lapse of time is considerably larger in the first case than in the second. (Roux.) The numerous small stimuli are in this case able to act cumulatively upon the body-cells concerned in the formation of the antagonistic substances, while by the other method a great part of the single large dose of foreign active proteid is at once eliminated. If it were a case of simple chemical combination, the total quantity of antitoxin formed would necessarily be the same in both cases in the same period of time. The toxins therefore act as stimuli upon the body-cells, and these forth- 
with contribute to the blood new defensive substances.

The "specificity" of protective inoculation with the anti-substances depends therefore only apparently, - just as in the case of protective inoculation with living parasites and with metabolic products, - upon the "specificity" of the microbes.

It would seem, accordingly, that the " specific anti-substances " of the blood resulting from "specific" immunization and establishment of tolerance of poisons are substances derived from "specific" disease germs, worked over, however, in a peculiar way and made active by "specific" body cells, or brought into union with an active proteid of the body to form a new and active substance. Emmerich has suggested the name "immunizing proteids" for these hypothetical substances.

\section{Do the Antitoxins Bring About Specific Immunity?}

The fact that new bodies of this sort are formed, that is to say that new qualities appear in the organism, does not necessarily prove that these substances are the ones that exert the specific protective effect. I have already urged this point, but have been unable 
to carry conviction until recently, supported by Gottstein and Schleich, I proved that a specificity of this kind must depend chiefly upon the fact that when a man acquires protective inoculation there must be stimulation or excitation of those particular, specific organs, tissues, cell-territories or cells which are especially involved in the disease in question. Just as bacteria can be separated into species, so also do differences exist between the cells of the different species of host animals and also between the cells of the various organs and tissues of the individual organism; the livercell is not only a cell : it is more than that, it is a liver-cell, and the liver-cell of a dog is not only a liver-cell, it is the particular sort of liver-cell pertaining to a dog. What is fair to the bacterium is only fair to the body-cell.

Still other reasons induce us to declare for the preponderating significance of the bodycells and against the determining influence of the bacteria in bringing about the establishment of specific tolerance of poisons. In the first place it is very improbable that where a genuine habituation to poison exists, or where an establishment of tolerance of simple poisons like ricin or abrin is effected, the habituation to these poisons is bound up with the formation of an altogether new and peculiar foreign body 
in the blood. Such an idea is hardly anything more than a hasty conclusion ad hoc. In habituation to alcohol no "anti-alcoholin" is formed, in habituation to morphine no "antimorphine," and yet a tolerance of these poisons is established apparently by simple intervention of the body-cells. The susceptibility of the body to such poisons and the degree of protective action established, vary according to the method of introducing the poisons, the period of life and other influences. The degree of habituation to poison that may be acquired is also very different according to the organs involved. Schleich has accustomed animals to receive with impunity large doses of chloroform, morphine and cocaine, and yet the animals are nevertheless poisoned with slight doses, when these are introduced directly into the brain, just as in Pasteur's method of inoculation in rabies. The highest grades of poison tolerance show indeed a definite dependence upon the method by which the tolerance has been brought about. This can signify, however, nothing less than a direct dependence of these conditions of tolerance or immunity upon the cellular influences of the human body, and these influences can certainly be brought to bear in the absence of any specific anti-substances in the blood. The poison tolerances belong in the same cate- 
gory with the phenomena which have been associated with the name of Mithridates, the king of Pontus, who fortified himself against poison by taking antidotes. The peculiar, specific influence of the body-cells may in itself suffice for our complete understanding of the matter. A specific influence of this kind, however, as may be inferred from our previous exposition, is dependent upon specific external conditions only in so far as the surroundings stimulate or set free predispositions already existing, as when for instance they cause a specially marked activity of the body cells which differs from the former condition only in a quantitative direction. Since the bodycells are not directly available for experiment, and we are often able to gain information as to their content of energy only indirectly through the setting free of energy, many investigators draw the fallacious conclusion that the specificity of the exciting germ is the sole determining factor and that a new quality is involved in the change that takes place in the organism.

The fact is important also that the active anti-toxins generally confer no immunity. If cultures of tetanus or diphtheria bacteria or of some other parasite be heated to about $65^{\circ}-70^{\circ}$ their specific toxic activity is taken away, while their capacity for conferring immunity upon 
animals still continues in force. Such heated cultures have gained at the same time in place of their toxic action, a protective power similar to that shown by the serum of animals made "specifically" tolerant of poison. In my laboratory Bunzl-Federn treatcd culture fluids with digestive ferments, and succeeded in the case of pneumonia in obtaining protective substances of the kind that, according to Behring, are supposed to exist only in the form of the anti-substances of the blood-serum, in those organisms that are tolerant of poison. Klemperer and Krüger, and Nencki and Smirnow reached the same result by making use of the action of the electric current upon toxic bacterial cultures. The hypothesis is untenable that in the latter experiments, which were condicted outside of the body, antagonistic substances are produced from the poisons. As with other bodies of this kind the poisons are destroyed by the treatment; the bacterial cell substances which confer immunity simply become modified, since the cultures thus deprived of poison are capable of bestowing immunity.

The samc result follows from other experiments. The anti-substances vanish from out of the blood rith relative quickness, and hence protective inoculation with these substances 
has been considered by Behring and Ehrlich as "passive." Now in the passive immunization that is effected in the case of diphtheria, the animal still remains immune after the antisubstances have disappeared from the blood, and experiments made outside of the body show that the blood has been robbed of all protective power. The explanation of this is to be found in the fact that the poison tolerance was effected by means of old cultures which contained, besides the poison, those bacterial cell substances which have already been shown to be the most important factors in active immunization (p. 3II).

If rabbits are inoculated with toxin-free tetanus spores together with lactic acid, the animals become immune, but their serum imparts to other animals no protection against tetanus (Roux and Vaillard). Immunity and poison tolerance are evidently, in this instance, not associated with the presence of antitoxin in the blood. Behring has found that it is possible by means of too frequent or too large injections of poison to immunize animals so highly_or more correctly to administer to them so much poison-that they exhibit symptoms of poisoning and become hyper-sensitive to the toxin, in spite of the fact that their serum displays the most powerful antitoxic action. 
In such a case the power of forming antitoxin is present without a corresponding immunity. According to Mosso, the blood of the eel possesses poisonous qualities, and according to Calmette, the blood of both poisonous and nonpoisonous serpents, of salamanders and of toads is also poisonous; the toxicity of the blood of all snakes is approximately the same, whereas snake-venom shows the greatest differences in the different species. In contrast to snakevenom, which, according to Fayrer and Ward, can withstand a temperature as high as $75^{\circ}$ and is weakened only at $80^{\circ}-90^{\circ}$, the poison of the snake-blood, like the generality of the active bodies found in the blood, is destroyed at $65^{\circ}-70^{\circ}$. These facts demonstrate the independence of the two poisons, one of another, and this independence is substantiated by various experiments. According to Sewall, whose experiments have been extended by Calmette, Phisalix and Bertrand, animals can be made immune against snake-venom, and also against poisonous snake blood (Calmette). Toxic serpent blood kills animals which are immune against serpent-venom, and conversely. In spite of this difference of action, one active poison does influence the other. Serpent blood that is normally poisonous may become temporarily non-poisonous in consequence of the 
establishment of a tolerance of the organism to serpent venom.

The blood of the hedgehog, according to Phisalix and Bertrand, is poisonous to guincapigs. If this blood be heated and its poisonous qualities destroyed, it is able to protect guinea-pigs against the bite of the common adder. The protection against the poison in this case evidently does not depend upon the action of an anti-substance, nor can it be due to the neutralization of the poison by a specific antidote.

When immunization is accompanied by the acquisition of a tolerance of poison it is frequently the case that no antidote for the specific poison can be discovered in the serum of the protected animal. Emmerich first proved for swine-erysipelas and pneumonia that the active bodies to which the properties of the protective serum are due act not antitoxically, but bactericidally; that is, that they kill the specific bacteria. Novy established the same thing for the swine-plague, and $\mathrm{R}$. Pfeiffer has recently discovered that the same fact is true of cholera.

In the latter case the normal serum of healthy animals may act bactericidally, although in a lesser degree than that of animals specifically inoculated. On this ground it 
may be questioned, as in the case of the antitoxin, whether the bactericidal substances of the serum are compounds of the bacterial cell substances with the active body proteids, or whether they are simply body proteids. On the first supposition, it might be expected that any newly-formed compound would, because of its recent origin, be especially reactive and able to act as an intense stimulus to the body cells. The appearance in this case of peculiar bactericidal and antitoxic substances would be only apparently traceable to the emergence of new qualities, to the creation of "specific" substances. The hypothesis might rather be held that, through the action of a chemical stimulus especially appropriate on account of its greater reactivity, what happens is merely that a larger quantity of the same bactericidal or antitoxic substance already present makes its appearance in the blood of immunized animals, and that a normal animal in a healthy condition already possesses the substance as a means of defense, but in a smaller amount. In spite of the proof that elements of "specific" microbes are concerned in the production of the antitoxins or germicidal substances found in the blood of animals "specifically" immunized or made tolerant of poison, it is very probable that these "specific" bacterial 
substances merely furnish the necessary stimulus. The peculiar antitoxic and bactericidal action observed in such cases is due to the qualities of the substances which are formed in the serum in larger quantities in those animals made immune or tolerant of poison; normal animals already contain the same "specific" substances but in smaller quantities. The property of specificity which is seemingly a newly-acquired quality, may not unreasonably be conceived of as a quantitative variation and as dependent upon the bringing into action of normal forces by appropriate stimuli.

The formation of antitoxin is certainly nothing but an accessory or concomitant to artificial immunity and habituation to poison, and, since it is not necessary for the acquisition of these properties, it is not their cause.

Before we discuss the consequences of this fact let us consider another side of protective inoculation in general.

Anticipatory Inoculations-Specific Curative Inoculations-Specific Serum Therapy.

In considering Brehmer's method for the cure of tuberculosis, I have already mentioned that the same remedies which nature employs to convert a predisposition toward disease into 
immunity and thereby prevent disease, may also be used to cure the disease. The same thing holds good of protective inoculations, which were at first used to prevent the breaking out of disease, or to render an attack of disease more mild. When disease broke out before the protective inoculation had been made, the so-called anticipatory inoculation was sometimes resorted to. Inoculation was performed in the usual way in the hope that an immune condition would develop quickly enough to protect the still uninjured individual. This was practiced, for example, in human small-pox with vaccine, and still more frequently in sheep-pox with ovine.

Pasteur introduced an entirely new idea. Immunity frequently makes its appearance very quickly. This was regarded erroneously as the manifestation of a specific character, but so far as it has been controlled by subsequent investigations, it seems often to be due merely to the sudden rousing to activity of the normal protective forces of the body by the stimulus of the invasion. On the other hand, the infection, starting from the moment of penetration of the disease germs, requires time to become manifest as a due sequence to the multiplication of the parasites and their formation of poison ; this interval is called the period of in- 
cubation. If the period of incubation be long the disease may require days before showing itself openly; perhaps in this intermediate period it may be possible to bring about a successful protective inoculation, even although a successful infection had previously occurred. Such was Pasteur's train of thought, and he sought to accomplish the desired end by making use of the much-discussed method of inoculation against rabies. If we do not neglect the local factor in protective inoculationalready several times mentioned-and the way in which immunity spreads from the place of infection to the blood and central nervous system, it must be unconditionally admitted that Pasteur's method of treating rabies has certainly achieved success in cases in which no favorable issue could have been hoped for from the use of other means. Partial success has been attained also in the method, described on p. 305, of inoculation with the metabolic products of bacteria, carried out on the same theory. That is to say, the incorporation of the protective substances is resorted to only after the disease has broken out.

In the same group of conceptions belongs the use of proteids for curative purposes. The first experiments were made in $1884-86$, by Ferran and Zaeslein, who administered dead 
cultures of comma bacilli to cholera patients. Koch's experiments with tuberculin, in I89o, are the best known experiments of this class, but the results obtained have not approximately fulfilled the hopes aroused. Such favorable results with this substance as have been recorded may be attributed to the power of tuberculin to excite inflammation, (p. 3I3), a point wholly missed by Koch and discovered by Hueppe and Scholl. F. and G. Klemperer have used the proteids of Diplococcus lanceolatus to combat pneumonia, and E. Fränkel those of the typhoid bacteria, as protection agairst typhoid fever, but without specially successful results.

In those cases which are to be regarded as instances of rapid immunization it is necessary to meet any increase in the intensity and duration of the disease, by administering stronger or more potent doses of the immunizing substance, so that the danger of poisoning the organism is increased. Acting upon his conception of passive immunity, Behring thought it possible to avoid completely this danger, and to cure certainly and without risk of harm, by introducing the protective serum, even after successful infection had been brought about. This is the real significance of the serum therapy, although, from the beginning, it has been 
represented by Behring in the light of an entirely ontological specificity of the micro-parasites. The serum therapy must be placed, therefore, in the same category with Pasteur's inoculations for rabies, and not in that with Koch's inoculations with tuberculin. According to this view one "species" of animal, man for example, is naturally immune against a "specics" of micro-parasite; immunity against the "specific" disease of small-pox can be gained only through "specific" small-pox virus, "specific" tolerance of the toxin of diphtheria, only through the "specific" diphtheria toxin; hence a completely immune body must contain "specific" antidotes against all these disease germs and also against their poisons.

The logical consequence of this doctrine as Pasteur, Koch and Behring have shown, is that against every "specific" infectious disease, a "specific" protective inoculation or an attempt to establish a "specific" poison tolerance must be adopted as the method of prevention or cure. The methods which have been employed for this purpose have been differently conceived and carried out in different epochs. In 1638 , a method of this sort was followed by Robert Fludd, who prepared a remedy against consumption from the sputum of consump- 
tives. This doctrine was set forth still more lucidly in $\mathrm{r} 833$, upon the basis of the fundamental proposition laid down by the German veterinarian Lux, that all contagions diseases carry in their own contagious matter, the remedy for their own cure. Formerly, this principle was called Isopathy, now it is called "Specific Therapy," in order that we may avoid the appearance of having learned anything from our predecessors, or of causing it to seem as if scientific medicine had any relations whatever with such scorned doctrines as Isopathy or Homeopathy. In reality, it is the same dogma in another garb. Lux, for example, prepared hydrophobin against rabies, variolin against small-pox, pneumophthisin against consumption-Koch now calls it tuberculin and Klebs anti-phthisin-and scarlatin against scarlet fever. But the chief difference in the preparations of Lux, was that the first was prepared for the dog, the others for the cat.

The fact has already been mentioned (p. 3 I 7 ) that,-before Behring and Kitasato,-Ferran, Héricourt and Richet, and Babes and Lepp sought and with partial success, to cure infections already in progress by the use of protective serum. Waggish philologists maintain, to be sure, that the practice is even much older, 
and that Horace, in his words "sero medicina paratur" must have been expressing his conviction that the universal cure would be prepared from serum. The principal service in the development of serum therapy was rendered, however, by Behring, who also knew how to interest in the problem careful fellow-workers like Kitasato, Ehrlich, Wernicke and others, with the result that in the minds of many workers the different varieties of curative serum now seem to present the sole opportunity for medical investigation, as some years ago, under the influence of the tuberculin investigation, was the case with the proteids.

The starting point of the serum therapy is the observation that animals, after being successfully infected regain their health when treated with a subcutaneous injection of the serum of immunized animals. The result varies according to the time which has elapsed since the infection. If, for example, the mucous membrane of the trachea is infected with diphtheria bacilli, the injection of serum under the skin causes, within 24-26 hours, the fibrinous exudate of the mucous membrane to be thrown off, stops the poisonous action, and prevents further general infection. When the infection is subcutaneous the fibrinous exudate in the derma is changed by the use of 
the serum into a suppurative one, so that, by sloughing off of the necrotic tissue local healing makes its appearance, and this is accompanied by the prevention of general infection and poisoning. If the serum injection be delayed more than 36 hours, the local disturbance may still frequently be healed, but, on the other hand, general infection is not prevented and is only retarded in its course.

Clinging to his notion of a "passive" protective inoculation in which only the animal producing the serum incurs risk, while the animal receiving the serum reaps the benefit, Behring has maintained with the greatest positiveness the absolutely innocuous character of the curative serum. But the statements made above on p. 327 concerning the nature of the anti-substances of the serum militate against his view. If we accept Behring's assumption of the purely specific nature of the anti-substances, the fact that one component of these substances is the bacterial toxin itself, as the cases of Buschke and Marcuse directly prove, is at variance with his idea that the anti-sera are altogether harmless. The following facts also are opposed to such a belief.

Favorable specific effects such as an immunity against living parasites and an habitua- 
tion to their poisons, are often deceptive, if we fail to consider sufficiently the method of introduction or inoculation. A state of protection against infection by way of the skin may be present in cases where immunity does not exist at all to infection by way of the blood or brain ; it may be present for one side of the body or for one extremity and be lacking in other regions. If this fact is forgotten then it may appear as if the influence of the body-fluids were preeminent, when in reality the last word rests with the body-cells. On this basis Schleich has very happily attempted to explain why diseases like diphtheria, that start from the mucous membrane of the throat, or that start from the lungs, like pneumonia and influenza, or from the intestines, like cholera, confer upon the organism little or no immunity from another attack; it is because large tracts of cells remain exempt from the effects of the first invasion and therefore acquire no protection. It seems as if perhaps toxic properties did not exist, when in reality toxic manifestations are prevented only by chance. The allegedly non-poisonous diphtheria serum itself, when introduced into the derma, shows a toxic action which manifests itself in pains and in swellings of the joints and in the form of peculiar and obstinate skin affections at times 
like those of scarlet fever or measles, as well as in bleeding, kidney inflammation and paralysis, and it is very doubtful whether the list of possible injuries is yet exhausted, for perhaps other mischievous effects may come to light with other methods of use. Occasionally, marked degeneration of heart, kidney and liver is witnessed immediately after the injection of the diphtheria serum; and this fact shows clearly that in the use of this antitoxin a danger exists of the same character as that displayed in Buschke's experience with the tetanus serum. If the action of the serum were simply antitoxic, danger of this kind ought to be impossible. We have the paradox of an antitoxin producing a toxic effect. According to Emmerich, animals that have been treated with diphtheria serum afterwards succumb more easily to an infection with Staphylococci and Streptococci, a fact that points also to a poisonous action of the antitoxin upon the tissues. In man an acute outbreak of tuberculosis has been more than once observed to follow a serum injection. In view of the assurance with which Behring brings forward his serum as something absolutely without precedent, terming it, by way of contrast to all previously known remedies, an "absolutely harmless remedy," it is important to show that 
the curative serum acts, to say the least, in the same manner as any foreign, active, fermentlike substance introduced into the blood and is not absolutely innocuous. There is serious disappointment in store for us if we do not succeed in ridding ourselves at once of the fallacy regarding the absolute harmlessness of the antitoxin. With the best intentions in the world it is impossible to understand what is the aim of such glorifications as those with which this remedy has been greeted and which remind us of the puffs of patent medicine, for the simple facts prove that the claims made are not justified. On the other hand, it is a question that is certainly open to discussion whether or not the employment of the serum upon man may still be recommended in the face of this real danger, for the risk may be considered as overbalanced by the benefits obtained in other respects. We may reasonably hope that if the chief danger, the infection with the specific disease germ and consequent poisoning with its toxin, be avoided through the agency of the serum, nature will easily dispose of the lesser accessory dangers. Looked at in this way, indeed, danger from the use of the tetanus and diphtheria sera does not seem to me to be great.

The tetanus serum, first used upon man by 
Tizzoni, has up to the present not yielded conspicuously successful results. A decisive success has, however, been claimed for the diphtheria serum, sometimes in an exceedingly unscientific and vehement fashion. Even scientific congresses take sides by a majority vote upon the question, purely scientific as it is, and certainly not yet ripe for conclusion, and seek to suppress the opposing view. The exaggerations in the tuberculin affair, for which afterwards no one was willing to stand sponsor, are still sufficiently mortifying to many clinicians, who by their manifest lack of critical discernment in scientific matters, were placed in a very unfortunate position. Yet this experience seems, inside of four years, to be completely forgotten. At present a somewhat more rational examination of the matter is being made with the aid of collective investigations, but the statistical material leaves almost everything to be desired.

In the first place the statistical basis is of a very dubious character. Conclusive control experiments under absolutely similar conditions do not exist at all. In certain cases the period of introduction of the serum has coincided with the occurrence of a mild epidemic. The mortality from diphtheria varied from I875-I89I between $6.2 \%-34 . \mathrm{I} \%$, in different 
cities (Feer); in Berlin (Gottstein) the mortality from r880-I894 ranged between $23.8 \%-46.5 \%$. Moreover, the mortality is very different in the different months, and in Berlin it varies enormously according to the district, in some parts of the city sinking even to $9 \%$. The occurrence of diphtheria was formerly determined clinically, and the anginas, the mild cases of throat inflammation, were left out of account. According to Behring, however, the diphtheria serum, because it is obtained by the aid of pure cultures of diphtheria bacilli is effective only against those cases of throat trouble that are provoked exclusively by the Klebs-Löffler bacteria. By adopting this classification the gravest cases of septic diphtheria are excluded. Further, it is asserted that the cases ought to be treated as early as possible. At present the proof of the prèsence of diphtheria bacilli is sufficient to lead to treatment with the curative serum, in spite of the fact that many cases in which the diphtheria bacillus is found never become diphtheria clinically, while on the other hand many cases are regarded as pseudo-diphtheria which clinically might be called true diphtheria. Under the influence of these three fundamental requirements, namely, that the diagnosis shall be based solely upon the presence of the 
bacillus, that every such case shall be taken under treatment as early as possible, and that pathological and clinical experience shall be left out of account, the statistics are distorted so extravagantly in favor of the serum therapy, that available material for comparison is lacking. In spite of this distortion the result of serum therapy in the hospitals is not so favorable as that obtained in the aggregate. Nevertheless there seems to exist in the hospitals a certain diminution of the mortality through the use of the curative serum, if the earlier results are used as a basis of comparison. It must be borne in mind that people who in quiet and coolly critical times would not come to the hospitals, do, under the influence of such excitement as was stirred up by Koch's tuberculin and by Behring's serum, betake themselves to those places where they will be tréated with the universal panacea. Keeping in mind both the essential change in the diagnostic conception of diphtheria and the successful results obtained with the serum, which are really considerable, we are still able to say that serum therapy, as well as protective inoculation with the serum, does not possess the character of a "specific" treatment. From a "specific" cure we must expect altogether different results from those thus far obtained, 
and above all the effect upon severe cases must be decisive, a feature in which up to the present this therapy has failed.

The collected statistics of the investigation in Germany during the period from October I, I894, to April I, I 895, showed among 4,4.50 calses not treated with serum a mortality of 622 or $14.7 \%$, among 5,790 cases treated with serum a mortality of 552 or $9.5 \%$. Direct comparison under exactly similar conditions of a sufficient number of cases can however not be made. I do not deny that the curative serum is perhaps able to influence diphtheria favorably, and that hence some slight progress has been made. I deny only that we have the right to set forth such trivial results as "specific," and such a method of treatment as the true and only really causal mode of therapy. On account of the merely moderate success so far attained, we are at liberty to hope that not only so much as is claimed, but perhaps even more, may eventually be compassed in a more simple and reasonable way.

The hope that immunization as well as cure may be effected with the use of the curative serum, must be abandoned as I have previously shown on p. 34I. The slight protection which the body seems to gain from the serum injection is not specific, and, in contrast to a true 
protective inoculation, is of very short duration; in diphtheria it varies from 8-I4 days to IO weeks at most. It is not possible to immunize effectively against diphtheria with curative serum, a fact which on account of the confidence we are justified in attaching to really specific protective inoculations is a matter of practical importance. This result of experiment is in full accord with clinical experience which has shown that an attack of diphtheria confers little or no immunity. Although it is generally possible to bring about some small degree of immunity with diphtheria serum the immunization does not necessarily have anything to do with the presence of special anti-substances. The slight protective effect that has been observed might arise from the fact that when old cultures are used we introduce into the animal besides the poisons other bacterial cell-substances which are capable of producing immunity; or it may be that the effect is caused simply by another sort of action due to the suitable stimulative action of a sufficiently active chemical body.

In line with Behring's conception, R. Pfeiffer has prepared a curative serum against typhoid fever by inoculation of animals with typhoid bacteria. Marmorek, also, who obtained very virulent cultures of streptococci by 
adding human blood serum to bouillon and with these brought about a condition of high immunization or tolerance of poison employed the serum of animals immunized in this fashion to protect against streptococcus infections. These streptococci are the germs of puerperal fever and erysipelas, and are also especially concerned in the septic conditions of diphtheria. The streptococcus serum therefore supplements, as it were, the diphtheria serum in complicated cases and mixed infections. These investigations are just beginning to be taken up scientifically, and are in part still in the advertisement stage; we shall have to submit to many a serum before connection is again made with scientific investigation.

Phagocytes and Alexins-Antitoxic and Bactericidal Substances in the Blood.

Up to this point we have considered only the subject of "specific" immunizations and the establishment of habituation to poisons. These phenomena seem to present a fundamental contrast to those of natural resistance or immunity. H. Buchner, especially, has laid great stress upon this contrast. In natural immunity there exists only the specific ability of the body to cope with definite parasites and their poisons ; in "specific" immu- 
nization, however, a "specific" something is added by the "specific" parasites.

The existence of this essential difference can be properly attested only by experiment. Fowls which are, by nature, immune to tetanus do not possess in their blood any antisubstance which destroys the tetanus toxin, yet these animals show no symptoms of the disease when they are injected with tetanus culture. . Natural "specific" immunity seems in their case to be connected with some general property of the tissues, in contrast to artificial immunity which is supposed to depend upon the presence of specific anti-substances in the blood.

In the first place, we must ask, what are the facts upon which we base our conception of the protective power of the human and, in general, of the animal organism?

As a matter of fact, the animal body ordinarily possesses the ability of ridding itself of bacteria and their toxins. It is always to be borne in mind in this discussion, that in certain diseases the toxins, and in others the bacteria themselves play the more prominent part. The fact that the animal organism can cope with living bacteria was observed in I864, by $\mathrm{M}$. Traube and Gescheidlen. These investigators introduced putrefactive bacteria into the blood, 
and noted that after a very short time, the germs had entirely disappeared. The eminent naturalist Metschnikoff, has since urged with great vigor the view that the wandering cells of the body, known as the white blood-cells or pus corpuscles, betake themselves to the place threatened by the bacteria, where, acting as "devouring cells" or phagocytes, they engulf the foreign bacteria, kill and digest them and thus render them incapable of doing harm. Certain of the fixed tissue cells, it is supposed, also possess this power of phagocytosis. It was known, some time ago, that the wandering cells possessed the power of taking up into themselves lifeless foreign elements found in the blood and of removing them from the bodyfluids, thereby making and keeping the blood and lymph channels free of foreign particles. There arose, consequently, the question as to whether the wandering cells generally kill the living bacteria or whether perhaps other influences kill the bacteria, and the wandering cells merely remove the lifeless bodies, just as they would remove other foreign bodies for the purpose of keeping free the circulatory channels. (See frontispiece.)

In I884, Grohmann found that cell-free blood destroyed moulds and bacteria. This fact was observed afresh by Fodor, in I887, and has 
been confirmed again and again in the course of: manifold and varied experiments. It was shown by Buchner that even blood that has been frozen, and in which the wandering cells have consequently been rendered wholly impotent, kills bacteria almost as quickly as fresh blood-serum. On the other hand, blood that is warmed to $60^{\circ}-70^{\circ}$ loses this power. From these facts, we must infer that the bloodplasma itself is able to kill bacteria in a purely chemical way; the substances in the blood-plasma, which are thus effective are the so-called "active proteids" or alexins. But certain of these active chemical protective substances are also able to neutralize the bacterial toxin, as we may conclude from the fact that if active blood-plasma is brought in contact with bacterial poisons outside of the body, the poisonous action of the latter is diminished or seems even to be completely annulled, whereas in the same blood inside of the organism, chemical combinations and oxidations or other transformations may also play a part in rendering the poisons innocuous or in eliminating them. The organism possesses in the peculiar chemical substance known as nucleic acid, which is found in the cell nucleus, a substance that kills bacteria and combines with basic poisons. A similar 
action perhaps goes on in the intestine, where the peptones of digestion, which produce a poisonous effect when injected directly into the circulation, are made harmless by being converted back again into proteid by the epithelium cells.

The organism, therefore, has at its disposal certain purely chemical aids, variously developed in the various organs, tissues or cells, for rendering innocuous the foreign, active or ferment-like soluble poisons, and it also possesses substances in solution in the bodyfluids, which are able to weaken parasites and destroy them.

The protective power of the blood is only manifested plainly outside of the body in the cell-free serum ; as H. Buchner discovered, it is diminished and eventually destroyed, in proportion to the amount of hæmoglobin with which the serum is mixed, a fact which explains why it is that the blood-poisoning diseases are so likely to run a fatal course. According to Hankin, the protective substances of the blood serum are derived from the leucocytes of the blood; they are, so to speak, proteid substances made active through the intervention of the living cells, and like the enzymes, they survive the cells forming them. Emmerich, accordingly, postu- 
lates the existence of a hypothetical "immunizing proteid" (p. 332), which is a combination of such active leucocytic proteid with bacterial proteid. The formation of such substances, however, is advantageous only when kept within certain limits. If too many leucocytes are broken up so that a cloudy solution, rich in eosinophilous granules arises, then such a serum, which when originally possessed of a merely moderately alkaline reaction and intact leucocytes could kill bacteria, may become through the steady increase in alkalinity a favorable nutrient medium for bacteria (Fischel). Hence we may find connected with the state of the serum all degrees of bodily condition from perfect immunity to a high predisposition to disease. During the interchange of substances in cell nutrition, other active proteid bodies may pass over into the serum from the cells and tissues of the body, and so by the indirect participation of those cell territories which are concerned in any special disease, these organic elements may be a factor in the predisposition to disease, without it being necessary to assume that anything of a foreign nature is added to the body. Within the body, however, blood or any body-fluid, if devoid of cells exerts no defensive action. Metschnikoff discovered, for ex- 
ample, that in septicæmic processes the cellfree aqueous humor of the cye-which contains alexins-not only fails to kill bacteria, but the bacteria grow in the fluid luxuriantly and multiply, whereas they die off in the blood of the same animals, when it contains cells. It is possible to enclose bacteria in permeable membranes and introduce them into the blood or tissue fluids. When this is done, the alexins that are present in solution enter the membrane by diffusion, but the wandering cells cannot penetrate it; the result is that the parasites grow in the fluids, although these contain alexin, but perish in the blood of the same animal in which the cells are present. Buchner interprets this latter occurrence by the supposition that in such experiments the number of bacteria introduced is too insignificant as compared with the quantity of the serum, but this explanation can be only partially correct.

Frequently the conditions are extraordinarily intricate, so that it is difficult to distinguish the share of the cells from that of the tissues. When a local disturbance occurs as the result of parasitic invasion, then a reactive inflammation with the formation of a limiting wall of lencocytes takes place, an event that must be considered as a natural healing pro- 
cess, and that often aids in recovery. Ribbert asserts that this surrounding mantle of white blood-corpuscles prevents nutrient material and oxygen from reaching the bacteria, but perhaps also the white blood-corpuscles disintegrate, and so become chemically active in the way pointed out by Hankin. In all such cases, there are certain stages in which the parasites in the foci are destroyed without being first taken up by leucocytes. Even Metschnikoff has lately admitted some such indirect participation on the part of the leucocytes.

According to R. Pfeiffer, if we inject into the peritoneum of a guinea-pig living cholera bacteria suspended in bouillon to which some cholera serum has been added, a remarkable alteration of the bacteria makes its appearance. They become changed to spherical structures, a transformation which R. Pfeiffer looks upon as a kind of disintegration, and explains as an accompaniment of death. More accurate experiments by Metschnikoff have, however, resulted in suggesting a somewhat different interpretation. If we proceed according to Pfeiffer's method, a disintegration of the leucocytes immediately follows the injection, and this disintegration takes place among those uninuclear, polynuclear and eosinophilous cells which Metschnikoff looks upon as 
primarily "devouring cells." On the basis of my own observations, I should refer this "phagolysis," this disintegration of the leucocytes, to the action of the foreign active proteids contained in the serum, since I have obtained a similar result with enzymes. The peritoneal fluid is by this means converted into a fluid over-rich in active proteid, and poor in phagocytes. Now when the bacteria are transferred from their bouillon into such a differently constituted fluid they attempt, as at all times when some injurious influence threatens the species, to withdraw themselves from the danger by passing into the resting-stage, and they consequently form arthrospores. Metschnikoff indeed regards these spherules in this light, and they do indeed appear like true arthrospores (Fig. ${ }_{9}$ B, p. 36), and not like comma bacilli which have undergone degeneration (Fig. 9, p. 19) or granular disintegration (Fig. IO, p. 20). To be sure, many of these spherules die, but very many also survive and really preserve the existence of the species, as Metschnikoff proved through obtaining cultures which yielded an abundant growth, a result which, if we adopted Pfeiffer's view, would not be expected to occur.' Later the fluid again becomes normal, these spherules are taken up by leucocytes and only then 
lose gradually the power to grow. In their intermediate stages also, as Metschnikoff discovered, many of these spherules develop again into comma and screw forms, although Pfeiffer supposed development to be impossible, believing that the germs were previously destroyed by the body-fluids. (Metschnikoff's observation, moreover, agrees in part with the observations of F. Fischel, so far as experiments which were conducted so very differently can be directly compared.) The leucocytes, returning after a time, take up in this second stage both the comma and screw forms and gradually destroy them. We know that the germs are taken up by the leucocytes while they are still in a living condition, and not after they have already been killed by the body-fluids, from the fact that the bacteria germinate in cultures. The body-fluids therefore, in spite of what at first glance has the opposite appearance, are not able to destroy the comma bacilli without the help of the cells. The effective agent in the fluids according to Metschnikoff is the active proteid afforded by the leucocytes (Hankin) and not a derivative of the peritoneal endothelium as R. Pfeiffer supposed. Metschnikoff was able to bring about the same result in a test-tube experiment by adding leucocytes to a bouillon culture of comma bacilli mixed with 
cholera serum. We may infer that it is the leucocytes and the substances derived from them which effect the change of the comma bacilli into granules, from the fact also that the same sort of disintegration takes place within the leucocytes. If bouillon be injected into the peritoneum before the injection of the bacteria mixed with serum, the disintegration of the leucocytes does not take place, but phagocytosis of the bacteria immediately begins and the germs are in part transformed into spherules inside of the phagocytes. One point appears certain, and is in accord with Hankin's observation, namely, that at least those active proteid bodies of the serum, which apparently arise from the white blood-corpuscles included under the term phagocytes, are able to exert a damaging effect upon micro-parasites, and that therefore the condition of the body-fluids is not in every case a matter of indifference. But such a condition of the fluids really depends upon the influence of the cells.

The bactericidal substance, therefore, which constitutes the protective substance or alexin of the blood plays an important part in the living body, but it is only one of the manifestations of phagocytic activity, since it is possible by means of specially devised experiments to suppress this chemical bactericidal action with- 
out altering the final result. The body-cells which by virtue of their specific and constant qualities convert the nutritive proteid into active proteid, thus bestowing upon it their own peculiarities which it in turn communicates to the fluids, are the factors of chief importance. Behring's doctrine of humoral pathology, that mysterious doctrine of the all-importance of the body fluids, which virtually ignores the cells, is a dogma vindicated by no sort of satisfactory experiment. The bactericidal active proteid substance that is found in cholera serum is certainly not an anti-substance against the cholera toxin (R. Pfeiffer) ; a truly antitoxic body has not yet been found in the blood after cholera inoculations, in spite of the statements of Behring and Ransom, although the occurrence of such a substance is not improbable. ${ }^{\mathrm{r}}$

The protective serum, as Behring terms it, certainly contains very different sorts of substances. Doubtless elements of the specific parasites enter into the formation of the antisubstances, and among these, perhaps, actual protective substances exist, but along with these, and in greater amount, occur those peculiar, normal active chemical bodies, which

1 Recent experiments show the existence of a cholera antitoxin. E. O. J. 
have been rendered active and brought into solution through the stimulus of a foreign proteid, and which in general act germicidally or antidotally.

Now C. Fränkel and Sobernheim have as a matter of fact shown that by heating protective serum to $70^{\circ}$ the bactericidal and antitoxic substances are destroyed, while the serum continues to exert a protective effect. The anomaly may be only apparent, and due to overhaste in generalization. The physical participation of the tissue-cells, of the wandering-cells, and of other mechanical aids, and also the share of the chemical protective substances of the blood (alexins) and of other chemical influences may be developed in different degrees in individual cases, and may manifest their activity differently according to the mode of attack of the parasites; just as the parasites themselves sometimes produce their effect chiefly through their multiplication, sometimes chiefly through formation of poison.

In every case the human organism possesses within itself powerful means of defence, both cellular elements and chemical substances. The latter are derived directly or indirectly both from the stationary tissue-cells and the motile wandering cells; these chemical substances enable the organism to cope with sap- 
rophytes and also with parasites and their poisons. This power is in itself nothing peculiarly "specific," but only specific to the extent that we are in general able to distinguish species and races, organs and tissues. In this general sense some species of microbes are able to enter into close relations with man, while others only sustain relations more remote and others none at all. Seemingly qualitative deviations are often only quantitative modifications of some of the fundamental activities that are common to all cells. The qualitative aspect is at bottom merely due to an accommodation of our ideas to the subjective limits of our knowledge just as we anthropocentrically distinguish light and clectricity, tuberculosis and diphtheria, without any intrinsic necessity. If this is kept in mind there can be no great harm in asserting that the natural resistance of man to disease-producing bacteria has a "specific" character, that it exists as a natural endowment protecting against certain species of parasites and not against others. It is another expression, a different statement of the well-known fact.

As compared with this condition, "specific" immunization presents further problems. Metschnikoff has found that before animals have received a protective inoculation against 
anthrax, the wandering cells of the uninoculated animal do not take up the anthrax bacilli and the same is true of some other diseases; after the protective inoculation, however, they all do this, and in each individual instance the protective activity thus acquired by the wandering cell is manifested, it is claimed, only against the one disease, and is therefore isopathic or "specific." The bacteria taken up by the phagocytic cells are not always digested, however, and may sometimes multiply in the cells and at their expense, a phenomenon that is often to be seen in swine-erysipelas, leprosy and tuberculosis. In the latter disease wandering white blood-corpuscles freighted with tubercle bacteria may distribute the parasites over the body, and so lead to general infection. But facts of this sort prove also that cells are able to take up into themselves living and fully virulent bacteria; they confirm therefore the contention of the phagocytc theory.

According to Behring the tissues form the anti-substances very slowly in the process of "active" immunization. But this notion is wholly incorrect. I hava already shown that the formation of anti-substances is only an incidental and not a causal and necessary accompaniment of immunity. Immunity may be brought about and yet these antagonistic sub- 
stances be altogether wanting. The more important factors are the active proteid bodies that are always present in the blood and tissue juices. These fluids are, however, dependent for their peculiar qualities upon the peculiar qualities of the cell-territories, and the "specific" substances stimulate just those cell territories which are of special importance for the individual diseases.

Effectual protective inoculation and habituation to poison come about only through the intervention of the body-cells, which are stimulated to one of the infinitely various activities made possible by their complicated structure, and which are prompted by the stimulus, to a mode of action differing only quantitatively from their normal activity, although the action is seemingly of a qualitative character and unprovided for in the physiological organization. The effect thus produced outlasts the transitory stimulus, because it is - bound up with the permanent and independent cellular elements of the body. The retention of the newly-acquired property depends upon the condition of the body, and upon the kind of stimulating substance and its manner of introduction; the more profound the stimulus, the more durably does it impress itself upon the organism, and the better is it fitted for in- 
terfering with the usual energetical processes of the body-cells. Viewed in this aspect, the "specific" bodies are as a rule best suited for attaining the desired end, but since their specificity is not due to an ability to effect a neutralization of molecule by molecule, other bodies also must be able to interfere in the same way and to influence the same "specific" cell territories. Even the passive protective inoculations are not entirely dependent upon the mere addition of chemical substance to the blood serum, but owe their influence to a stimulus to the cells and a corresponding reaction on the side of the cells, and hence in reality they also are active.

The distinction between active and passive inoculation is only a quantitative one, and both kinds of immunity result from the action of "specific" stimulating substances upon the body-cells and the reaction of the cells to these stimuli. The "exhaustion hypothesis" first propounded by Klebs and Pasteur, according to which certain substances occurring in the organism of the host and necessary to the life of the micro-parasite are exhausted by the growth of the parasite, thus rendering the host an unsuitable culture medium is untenable. The "retention hypothesis," put forward by Chauveau, which supposed that metabolic 
products accumulate in the body of the host and are injurious to the bacteria forming them in the way that lactic acid is injurious to the lactic acid bacteria, or alcohol to the yeast cell, is in a restricted sense correct, and agrees with what we know of the formation of antisubstances, but the hypothesis itself has no special significance.

The distinction between natural immunity and artificial immunity can no longer be maintained. In both, the wandering cells may be able to take up parasites. Even in naturally immune animals, anti-substances may at times be present. Abel has found sometimes present in the blood of healthy men an anti-substance that protects against the diphtheria toxin; Stern has found one protecting against the germ of typhoid fever, and Metschnikoff one against cholera, and on the other hand, as already mentioned, animals that are specifically immunized against these diseases, may not possess any anti-substances in their serum.

The conditions of hyper-immunity, natural immunity and artificial immunity are all resident alike in the cells and tissues of the body. The wandering cells of an animal may be endowed from the outset with special voracity or they may acquire this property, for the wandering cells, of course, are both directly and indi- 
rectly deperdent upon the condition of the whole body. The tissue juices also are able to interpose in the contest, by virtue of the active proteid substances they contain. That very quality, however, which, according to Behring, is the cardinal one, namely, the possession of anti-substances, the very character wherein the "specificity" of the parasite is most sharply expressed, appears to be of secondary significance. The anti-substances are frequently absent where immunity exists, and their presence or absence is without regularity. This fact helps to perplex us still more about the phenomenon of "specificity," so far as " specificity" is looked upon as an explanation of the real heart of the matter, or the "specific" microparasite is regarded as the exclusive factor in the production of immunity. Where Behring and Pfeiffer speak of the specificity of parasites and anti-substances it is more correct to speak simply of the activity of body cells and fluids.

If stimuli act upon a normal physiological condition that exists as a momentary adaptation or upon a condition of health regained after a complete cure, the stimuli that sometimes effect protection and cure may, by repetition, bring about at times a more ready discharge of energy (as we witness in the 
"learning" of physiological stimuli), and the irritability or disease predisposition is heightened. This is what happens in rheumatism, catarrh, influenza, pneumonia and diphtheria. Or it may be that the resistance to a discharge of energy is increased as the result of adaptation, and thus an habituation to the stimulus makes its appearance, so that the same stimulus is no longer able or is less easily able to cross the physiological threshold and cause reaction. The degree of resistance not only varies greatly in different diseases, but even in different individuals towards the same disease. There are some men who become ill through vaccination, and others who gain through vaccination no immunity whatever against small-pox. Only a slight immunity is acquired as the result of an attack in some diseases, as, for instance, in tetanus and cholera.

A part only of the "specific" curative inoculations - possibly, for example, Pasteur's inoculation against rabies-are to be conceived as anticipatory protective inoculations. The action of the anti-substances in serum therapy, especially, shows that some of these cures by injection have nothing to do with protective inoculation and depend simply upon the effect of one active body, the antitoxin or the prcteid of the serum, on another active body, the 
toxin; the brief immunity that accompanies the cure, results from stimulation of the natural defensive forces of the organism, and from the rendering of these forces active, and is an accessory phenomenon which does not contribute to the cure. Such curative effect as we strive to obtain with serum, and do obtain in such very different degrees, must be much more general in character than that obtained by "specific" antidotes against "specific" poisons, and can be brought about in a far simpler way. Even in those cases in which we are unwilling to relinquish the specific disease germs as the starting-point in our quest for a curative substance, we may well find some way to spare ourselves the time-robbing, expensive and circuitous route through the body of animals.

Are There Protective and Curative Inoculations That Are Non-Specific?

It was shown, in I889, by Woodhead, Wood and Hueppe that it is possible to immunize animals against anthrax by inoculating them with the bacillus of green pus (B. pyocyaneus), and its metabolic products. It was then shown by Hueppe, and confirmed by Klein and Sobernheim, that it is possible to immunize animals against cholera by employing many 
different kinds of bacteria and bacterial products, and it was at once recognized that the basis for this result lay in the rendering active both of the ordinary cellular defensive elements of the body and of those chemical elements that have gone into solution, although Klein erroneously supposed that the bacteria employed in these experiments form the same poison as that formed by the cholera germ and bring about their protective effect by causing an habituation to their poison. These first experiments were prompted by certain unexpected results of investigation. The discovery was made that if we introduce into cultures of parasitic bacteria micro-organisms of a different sort, as, for instance, the bacilli of blue-green pus into cultures of anthrax bacteria, the latter grow more feebly. These experiments belong in the class of antagonistic effects described on p. II9. In such cases, there could be no question of any "specific" protective inoculation or of any adaptation to a specifically identical material from the cultures, or of any habituation to the presence of the same sort of foreign protoplasm or to a similar poison. In the course of various attempts made to bring about the cure of bacterial diseases in this way we gradually learned to see that the effects produced depend upon the excitation of an in- 
flammation, and hence upon a stimulation of the cell territories already seized by the bacteria or involved in the invasion.

After it had been discovered by Nägeli, Pasteur and Koch, and still more precisely by Emmerich, Freudenreich, Woodhead, Wood and Hueppe that some pathogenic bacteria are destroyed in cultures by saprophytic bacteria, the attempt was made to effect a cure by incorporating such saprophytes into the body of previously infected animals. Clinical experience afforded some justification for this procedure, as for instance in the observations that cancerous tumors degenerate if the bacterial disease of erysipelas makes its appearance at the diseased locality, and that the sickening odor of a cancer may abate and even cease when bandages wet with a lactic acid fermentation are applied. Cantani, by his use against tuberculosis of bacteria of putrefaction was the first to employ such a "bacterio-therapy." Animal anthrax was more satisfactorily combated by Emmerich, di Mattei and Paulowski, by use of the living bacteria of erysipelas or the microbe of the bleeding-host $(B$. prodigiosus), and by Bouchard, Woodhead and Wood by use of the bacteria of green pus. Up to the present, therefore, we have attempted to imitate two natural methods of producing im- 
munity, first, the isopathic, or homeopathic, that is, the prevention of infectious diseases through inoculation, after the manner of vaccination against small-pox, and second the antagonistic or allopathic, the utilizing of the antagonistic action of different species of bacteria in their struggle for food.

The experiments upon antagonism which were made with living bacteria were repeated by the same observers with the metabolic products of the germs. The result was the same, both for protective and curative purposes.

Römer was the first to prove that it is possible in dealing with animal tuberculosis to obtain the same success with the use of the proteids of other bacteria as was gained with tuberculin. Along the same line, C. Fränkel attempted to influence favorably the course of typhoid fever by use of the proteids of the typhoid bacteria, and Rumpf achieved the same result with the proteids of the bacteria of green pus, while other proteids did not work so well. Since these experiments were carried out upon man, I will briefly set forth the results so far as the statements permit of comparison.

Fränkel recorded among 6o cases of typhoid fever, 5 deaths or 8.3 per cent., Rumpf among 
only 30 cases 2 deaths, or 6.6 per cent., while Gläser's statement regarding 3285 cases, from I869-i 877 , without specific treatment, showed a mortality of 7.5 per cent., with a minimum of 5 per cent. and a maximum of 9.6 per cent.; in the general hospital at Hamburg between I 882-I89I, the fatality was 2298 among 25,824 patients, or 8.9 per cent. with a minimum of 6 per cent. (I887) and a maximum of I9 per cent. (I882). How far larger numbers would affect for the worse the results of Fränkel and Rumpf we can not conjecture since the above data were communicated before the termination of all the cases. The only conclusion that can be fairly drawn therefore, is that it is possible to inject both isopathic and antagonistic substances into typhoid patients. Whether it is possible to bring about a cure by this method is still wholly uncertain; in any case the same result was achieved,-probably even a better result,-without use of any of these remedial substances and therefore without risk of doing injury.

The proteids bring about their effect (as shown on p. I8o) in a general way, by exciting inflammation in the tissues invaded by the microparasites. H. Buchner has proved also by researches made upon the action of arsenic that the reactions of the human body taking 
place in the form of inflammations can be made serviceable for curative purposes without there being anything specific about the process. In the chapter upon the healing of disease in general, I have already mentioned the fact that by evoking similar reactions from the body through the use of physical agents, it is possible to arouse to temporarily exalted activity the natural protective forces residing in the local cells, the wandering cells and the active chemical bodies of the tissue fluids. In the same way the rise of bodily temperature, if it does not overstep certain limits may have a good effect upon the course of the disease, and the idea of the older physicians who regarded fever and inflammation as the healing efforts of nature, may thus in the light of experiment turn out to be, to a certain extent, correct. The old view that an excretion of the "materia peccans" takes place by means of the kidneys, intestine and stomach is, likewise to be regarded as correct within certain limits (p. 202). All symptoms of this character are the outward signs of a natural and necessary reaction towards an impulse that tends to liberate energy. Symptoms in themselves may be either good or bad. How far they are actually beneficial or injurious depends upon the point of view 
or upon the special circumstances of the - case.

Starting from the idea of antagonism and from the clinical observation that morbid tumors are favorably affected by an outbreak of erysipelas, Emmerich and Scholl have made animals immune against streptococci, and have attempted to cure anthrax, tuberculosis, sarcoma and cancer with the serum of these animals. While Emmerich and Scholl obtained good results in their experiments upon man, other clinicians who have worked with this serum have up to the present time not met with success.

With a more precise analysis of the facts, then, it appears that the specific serum containing the antitoxin does not cure because it immunizes, but that it cures in spite of its not immunizing. The serum cure is not a sort of rapid immunization, but is based solely on the fact that strongly active bodies present in the curative serum act antitoxically or bactericidally, and hence display in an exalted degree an activity which we find exists also as a general capacity of the normal healthy serum of all animals, although developed in different ways according to the species. There is, in fact, between the antitoxic and bactericidal power of the normal serum which is deter- 
mined by the species of host-organism, and the same property of the serum which has been acquired or heightened by specific immunization or habituation to poison, not a qualitative but merely a quantitative distinction. The stimulus that produces a state of immunization and habituation to poison has , the visible effect of increasing the quantity of active bodies in the blood serum. Only seemingly in this case has a new qualitative character been added, for the bacterial components found in the curative serum have nothing to do with the antitoxic effect. The bacterial substance constitutes merely the special form of stimulus and may be altogether absent without any change in the result if only in some way or other there is provided some sort of stimulus which induces the specific cell territories and cells of the host to generate sufficient quantities of the active bodies.

The bacterial component,-and this can be regarded as the sole specific element,- - is certainly not essential to the formation of the antitoxin as is seen from the following experiments, which in great part we owe to Roux and his pupils Calmette, Phisalix and Bertrand.

I. The normal serum of healthy warmblooded animals acts in vitro upon specific toxins just as if it contained specific antagonistic 
substances. The blood of healthy men in many cases neutralizes the diphtheria toxin (Abel), the typhoid toxin'(Stern), and the toxin of cholera (Metschnikoff), while it has no effect upon tetanus toxin, snake venom and abrin. (From the first observation, Wassermann has drawn the far too hasty conclusion that in such cases the healthy individuals had previously resisted a mild attack of diphtheria.) I have called attention previously (p. I83) to a similar observation of Héricourt and Richet to the effect that the serum of healthy dogs protects rabbits against staphylococcus pyæmia.

2. Antitoxins that are formed specifically in serum act in vitro upon poisons of a specifically different character in the same manner as upon poisons specifically similar, while the converse does not always obtain: "anti-venin" annuls the poisonous effect of abrin, but not of diphtheria toxin, tetanus toxin or ricin; antiabrin neutralizes the toxic effect of snake venom, diphtheria toxin and ricin, but not that of tetanus toxin; tetanus antitoxin is antagonistic to snake venom, but powerless against ricin and abrin ; rabies serum is potent against snake venom, but impotent against the diphtheria and tetanus toxins, and against ricin and abrin; streptococcus serum is potent against snake venom, powerless against the others; 
cholera serum is moderately effective against snake veriom, but without effect against the others; diphtheria antitoxin is powerless against snake venom, tetanus toxin, ricin and abrin; the antitoxin sera of swine-erysipelas and typhoid are powerless against all these poisons.

3. Within the animal body, also, specific serum anti-toxin may exert an effect upon specifically different poisons. The serum of animals immunized against the venom of any one species of snake protects animals against snake venom of any other species and against scorpion venom. The serum of animals immunized against cobra poison renders rabbits immune to abrin. When Marmorek wished to endow animals simultaneously with the antitoxin protecting against diphtheria and with that protecting against streptococci, and for this purpose injected streptococci into horses which Roux kad previously immunized against diphtheria, the animals endured the treatment almost without reaction while animals not previously treated for diphtheria reacted very vigorously; the diphtheria antitoxin, therefore, in the body of the animal exerts a protective action against the streptococci and their toxin.

4. Antitoxins which in vitro neutralize specifically similar or dissimilar toxins may 
be without effect in the animal body. The civet-cat is immune against the bite of a serpent and its serum is antitoxic against snake venom, so that the reason for the natural tolerance of the poison might be thought to be the possession of this quality. The blood of the hedge-hog, however, which is likewise immune against snake venom, contains also, but in much slighter amount, an antidote against the snake venom. Swine, on the other hand, which are also immune bear in their serum no antitoxin against snake venom, and dogs, which do succumb to snake bite, possess in their blood an antitoxin against snake venom. The antitoxin is therefore sometimes present, sometimes absent, sometimes it is of assistance in protecting an animal, sometimes not. Animals immune to tetanus, and likewise animals immune to abrin, succumb to snake venom, in spite of the fact that both tetanus antitoxin and anti-abrin paralyze in vitro much larger quantities of snake venom than would suffice to kill these animals. Diphtheria serum mixed with abrin retards the poisonous effect of the abrin in the animal.

5. A serum or antitoxin which in vitro does not act upon the poison may yet exert an antidotal or curative effect when injected into the body of the animal. Rabies serum does not 
immunize animals against rabies, but does against snake venom. The serum of rabbits which have been immunized against rabies protects animals against cobra venom almost as well as does the cobra anti-venin itself. Dogs, however, which are immunized against rabies, and possess a serum protecting other animals against snake venom are themselves susceptible to snake venom. On the other hand rabbits immunized against snake venom have become resistant towards the "streetvirus" I of rabies, but still succumb to the more virulent rabies of rabbits.

6. A protective and curative effect may be wrought without the specific antitoxin. Animals immunized for abrin are immune against anthrax (Calmette). Rabbits immunized against anthrax are relatively immune against abrin, but their serum contains no anti-abrin. The fact that fowls immunized against tetanus possess no tetanus antitoxin has already been mentioned. The antitoxin that is present in the blood after immunization is therefore at least superfluous for purposes of protection.

The specificity of action of the anti-substances is obviously not essential to their antidotal effect, and it is therefore not necessary to assume it in a causal interpretation of im${ }^{1}$ The rabic virus procured from dogs which is of a constant intensity. 
munity. The common feature in all cases of immunity of this sort is the formation of active bodies in the serum of the immunized animals by means of the stimulus exerted by the poison that is introduced, and it is the action of these active bodies upon the active poison that causes the molecular movement of the latter to cease. Sometimes the specific, isopathic stimulus of the same nature is best adapted for thus rendering active the body-proteid, and hence is in a sense necessary, but sometimes a heterogeneous and specifically dissimilar, or even an entirely foreign stimulus is sufficient. Although the results of the experiments upon man are still in dispute the results obtained by experiments upon animals with specifically different bacteria, metabolic products, proteids and sera are frequently just as favorable as the results obtained by isopathic and homeopathic treatment with specifically identical or closely similar material.

For protective inoculation and healing, accordingly, isopathy or the use of specific disease germs and their metabolic products is not essential; the same results can be reached with other bacteria. But probably it is not essential that bacteria or bacterial products be employed for this purpose. In experiments upon animals I succeeded in the case of two 
diseases, pneumonia and cholera, in influencing favorably the course of the disease by other active bodies, and in curing entirely without the use of chemical substances of this class.

Protective and Curative Inoculations Without the Use of Microparasites or Their Products.

Immunity may certainly in some cases be obtained by other methods of treatment. Wooldridge in I 888 prepared from the thymus gland of the calf and from other tissues proteid bodies in the form of "tissue fibrinogen" with which he obtained immunity against anthrax; this sort of immunity probably depends upon increased leucocytosis and the phagocytic action thus made possible. Upon this action of the thymus proteids also depends the fact that cultures of pathogenic bacteria grown in thymus bouillon are at times impotent. (Brieger, Kitasato and Wassermann thought that the thymus removed the toxic quality of the cultures, but this is not the case.) I myself was able to confer immunity against cholera by use of the digestive ferments. Soluble active spermin in an alkaline medium is able to immunize for the reason that it evokes a favorable leucocytosis (Poeh1). If the formation of insoluble active spermin out of the nuclein of the 
leucocytes, together with reduction of the alkalinity of the tissue fluid, goes on in the body itself, basic bodies accumulate and act as autotoxins, and the leucocytosis becomes of an injurious character, e. g. post-hæmorrhagic, cachectic or ante-mortem. Hildebrandt rendered rabbits immune against the ferment emulsin, and these animals then showed immunity likewise against the bacteria of rabbit-septicæmia. A sort of natural immunity existed normally and this was heightened by a special impulse which simulated a specific protective inoculation. In all these cases other " active " proteid bodies acted as a stimulus upon the body cells in just the way that "active" bacterial protoplasm is supposed to do. Natural immunity is thus united by a series of intermediate links with acquired and specific immunity. The common feature lies in the stimulation of the particular cell territories and wandering cells which are necessary for defence.

Not even bodies of the kind under consideration, however, are essential. Ordinary chemical substances, if they are able to interfere in the continuity of energy, act in a similar way. This is indubitably true of those cases in which the cure depends upon the excitation of inflammation, and Liebreich has done us the great service of showing that in tuberculosis the 
same effect can be brought about with cantharidates as with tuberculin. ${ }^{\mathrm{r}}$ Dixon showed subsequently that creatin had a similar effect, Hebra did the same thing for thiosinamin, and Mosetig for teukrin, and Spiegler has still further added to the list of such substances. To the same class of therapeutic methods belongs also the intravenous injection of cinnamic acid in human tuberculosis (Landerer). This substance, likewise, seems to act through the excitation of inflammation and so far has appeared to afford the best results obtained with any of these compounds.

Localized hyperæmia, such as makes its appearance in consequence of the diminution of the original pressure caused by opening the peritoneum may act favorably; and cure has in fact been effected in peritoneal tuberculosis by means of laparotomy. Acting on this conception Bier has recommended producing artificial hyperæmia by the use of bandages in cases of tuberculosis of the limbs. We must assign to the same class of phenomena the fact that, according to Rokitansky, tuberculosis often sets in when an anæmic condition of the lungs prevails as the result of

${ }^{1}$ Outside of the determination of this fact little consideration has been devoted to the question whether these salts contribute as much as or more than tuberculin to the cure of tuberculosis in man. 
defective heart action, while on the other hand when the lungs are hyperæmic tuberculosis does not occur. According to many statements success has been attained by the use of small doses of quinine and arsenic as prophylactics against malaria. This result has been brought about by stimulating the body cells, so as to increase the defensive powers of the whole organism, a fact that for the sake of completeness I have mentioned before on p. I62 in connection with the discussion concerning the curative effect of quinine.

The non-specific actions, however, go even further than this. Rummo, for example, has accustomed white mice to strychnine. The serum of these animals contains no antitoxin; they have not acquired immunity against snake venom and diphtheria, but they have acquired immunity against tetanus. In this case the modification of the toxic action wrought through the stimulative effect of the strychnine upon the spinal cord is certain, and the influence of the body cells is strikingly apparent. At one time Behring himself produced a certain degree of immunity against anthrax by the use of iodine terchloride. Schutz also has cured with iodine terchloride animals which had sickened with swine erysipelas, and has protected healthy animals 
against the disease by preventive treatment. The blood of animals protected with iodine terchloride imparts immunity to healthy animals and cures animals already affected. In this case the notion that any specific antitoxins are formed is entirely without justification; the action may depend only upon some general protective power that is acquired, or upon a quantitative intensification of the defensive power already existing, that is, upon the rendering active of the cells and the active proteids of the body fluids.

Although many negative experiments with other bacteria have been made, yet the positive results already obtained are sufficient to make clear the falsity of the ordinary one-sided interpretation of "specific" protective inoculation and habituation to poison.

General metabolic influences also may simulate specific immunization. Von Fodor has shown that the resistant power of rabbits to anthrax infection is increased by the subcutaneous addition of alkalies to the blood and Kurt Müller has shown that the resistant power of white rats to anthrax is exalted by the subcutaneous injection of meat extract. We may hence justifiably infer that it is possible by suitable nourishment together with a flushing of the body by bodily exercise to 
heighten the general immunity, as indeed Pettenkofer and G. Jäger have demonstrated. A properly nourished and exercised body is able to cope with many species of bacteria simply by means of its normal body cells and fluids, without its being necessary for us to assume the existence of anything heterogeneous and "specific".

It is demonstrable, therefore, in ways that differ quantitatively according to the method used, that by means of very various impulses the natural protective and defensive forces of the human organism, of its organs, tissues, cells and fluids can be made active or by stimulation raised above the normal. The liberating stimulus then becomes, as it were; a stimulus to increase resistance. It may even be that stimuli of entirely different characters evoke a defensive reaction as great as was formerly attributed only to specific stimuli, whereas the latter stimuli sometimes bring about only a tolerably moderate defensive reaction. In general, however, the defensive reaction which is provoked by isopathic or specific stimuli is the stronger and more persistent and hence often appears to be peculiar in kind. But we can really understand everything that the mysterious doctrine of specificity has tried zealously to render obscure by re- 
ference to what is already known of the physiological protective forces of the body and the manner in which they are stimulated or called into activity. The specific methods of calling the bodily forces into activity are usually to be preferred, since stimuli of this character bear a recognized relation to the defensive organs of the body, but by this I do not mean to claim that they are the sole or always the best means of producing the desired effect. Any such notion as the doctrine of specificity must be set aside if we do not wish to bar the road to a scientific interpretation of immunity. A protective inoculation may appear specific not only when it is brought about by isopathic or specific bacteria and their products, but also when it is attained by means of stimuli of a wholly different kind. On the other hand the use of appropriate specific stimuli may call into activity only defensive contrivances of a slight and generalized character.

The question is not whether something is demonstrated or demonstrable in every case, or whether it is the best or most practical thing, but it is rather whether the thing exists at all. We are able to trace back the various forms of specific habituation to poison and protective inoculation, like those of natural curative and protective power, to the same general natural law 
under which come the phenomena of natural immunity and predisposition to disease. The possibility of recognizing such a high conformity to law in these broad processes seems to me to impart a truer perception of these things than the totally blind and mystical idea of "specific" activity, a conception which is no longer consistent with belief in organic continuity. I once compared such boundaries in nature to the jurist's treatment of his paragraphs, as projections of the beams in our eyes which we all carry on account of the limits of our subjective knowledge. Every line which we are able to obliterate affords us truer insight. On the other hand I must oppose that affected simplicity which is not the mark of truth, however it simulates it, and which is able to see in bacteria alone the cause, the prevention and the cure of infectious disease. It is not a question of a simple equation with one unknown quantity, but more correctly of a greatly involved equation with three variable quantities. 


\section{CHAPTER VII.}

THE PREVENTION OF INFECTIOUS DISEASE BY COMBATING THE CAUSE OF THE DISEASE.

WHEN the devastating disease of cholera first invaded Europe early in the present century it caused great mortality. This destruction of life led the authorities first in England and later in France and Germany, to make accurate record of the morbidity and mortality statistics of infectious diseases, both independently and in their relations to other diseases. The reform of medical statistics begun in England at this time afforded science its first basis for the comparison of the data of disease.

Epidemiological observations upon cholera made it probable that cholera is not strictly a contagious disease but that it sustains relations with the outside world, especially with the water and the soil. From this fact impartial observers deduced the probability that the frightful havoc wrought by cholera might be due to the unhygienic surroundings of city dwellings which at that time were thoroughly bad, and they declared that all human sur- 
roundings must be made sanitary and wholesome. Under the pressure of events, which gave to cholera the title of " the police force of nature," not only a complete and thorough organization of the English public health service was effected, but those sanitary reforms in sewerage and water-supply that were then thought to be necessary, were introduced upon a larger scale and the carrying out of such measures was often made compulsory. The result justified the endeavors, and when cholera broke out anew its violence was greatly diminished and it was altogether suppressed in those localities where sanitary measures of this sort had been adopted. The favorable effect of these reforms was shown not merely in the case of infectious diseases of the character of cholera and typhoid fever. We soon learned to regard those infectious diseases which furnished the larger part of all cases of sickness and death as "preventable" diseases. Simon, Farr, Parkes, Pettenkofer, and Stamm were the men who were foremost in furthering this work. But in spite of the great improvement, all diseases were not prevented. The influence of sanitary measures made itself felt chiefly in respect to those infectious diseases which, from their method of dissemination, required us to assume their connection with the outside world, while 
the effect upon the so-called constitutional diseases like tuberculosis, - which we must now regard also as an infectious disease-was less marked and the real contagious diseases like small-pox and scarlet-fever were only indirectly affected.

If we bear in mind what was remarked earlier regarding the development of strict parasitism out of occasional parasitism (p. 257) and that of this latter condition out of simple putrefactive power, we are at once in a position to understand how it is that works of sanitation which directly improve the soil and water may affect directly only those disease germs which stand in some sort of relation to the outer world. Measures of this kind cannot in general act directly upon the occasional saprophytes, and the strict parasites of the kind found in tuberculosis and relapsing fever, and which may possibly be present in the acute exanthemata like typhus, small-pox and scarlet fever. When such measures do exert an ameliorating effect upon these diseases and diminish the number of cases, only an indirect action can be claimed. This indirect action may be exerted in different ways. These measures may for example hinder or prevent the passing over or transfer of disease germs to human beings, and they may also, through the im- 
provement of sanitary conditions, diminish the predisposition of man to disease and increase his power of resistance. Hygienic measures therefore do not aim necessarily at preserving every life at all cost, but rather at favorably modifying the constitution of man, and elevating the general hygienic condition of the race. Whereas Pettenkofer sees in the "circumstances of time and place" and their modification by works of sanitation, an influence that can be exerted only upon the parasites as found outside of the body, and Koch considers of moment only the influence of these measures upon the transmission of the parasites, it was proved by Hueppe in 1887 that the "local disposition" consists also and perhaps chiefly in the influence of the local surroundings upon the human beings living in the place. We may now hold this opinion also on the basis of bacteriological evidence. In I889 Hueppe and Wood discovered that harmless bacteria found in a certain locality could confer protection against specific diseases, while on the other hand Metschnikoff discovered in 1894 that the invasion of the cholera bacteria is favored by the presence of certain saprophytes. Such "indigenous" saprophytic microbes may act upon the predisposition toward disease possessed by the 26 
dwellers in a given locality so as either to diminish or increase it. The inhabitants of any locality are affected not merely by soil, water and air, but also by other and varying conditions of time and place, for example by nourishment, by habitation and by social environment, as we see exemplified in the fact that the development of similar industrial conditions has everywhere brought about a parallel increase of tuberculosis.

The so-called works of sanitation act, then, by influencing favorably certain social factors. But this influence varies greatly according to the very different weight which the predisposition to disease, and the conditions for the conveyance of the disease and disease germs possesses in the various infectious diseases. Whatever the theory of the matter may be, the spirit is as little affected by our interpretation as is the spirit of the law by craftily constructed paragraphs. I must hark back again to the multiplicity of the phenomena involved; in this chain three links, to keep to my comparison, are of special importance. One of them has been viewed by Pettenkofer, and another by Koch in a one-sided way, but the three together have been sufficiently considered by no one.

If we remember that in practice, we estimate 
provisionally, though not quite precisely, the number of sick persons in the community by the actual mortality, then the total mortality can be looked upon as an expression of the force of constitution or of the sum of the bodily energy of the inhabitants of a town or country, that is convertible into effect not by a physiological but by a pathological stimulus. The contrast between physiological and pathological is of course employed only in an anthropocentric sense; for nature herself deals only with a struggle for existence, with a selection of the fittest to resist disease. If we remember furthermore that all forms of parasitism can develop and must have developed out of the putrefactive processes so essential in the cycle of life phenomena, we are at once able to understand how, so long as there exists available energy in a form departing from that of the normal physiological organization, nature will cause an increase in some diseases, a decrease in others, or permit wholly new diseases to develop out of the numberless possibilities which putrefactive processes hold always in store.

A réal and permanent decrease in infectious disease is possible only when there exists less energy capable of release in this form, when in other words we remove the pre- 
disposition to disease and increase the resistance and cause thereby all setting free of energy to take place physiologically. So long as this is not the case infectious diseases will be always with us, though some of those now prevalent may disappear, while others will remain, and entirely new ones arise. Viewing the question in this aspect, it is easily seen that the infectious diseases can be designated as preventable diseases only with some reservation. The infectious diseases are the expressions of an actually existing and unavoidable situation or state of adaptation, which, however, by paying heed to the causes that lead to it may to a certain extent be prevented from recurring in the future. I have elsewhere expressed myself in a similar way, for the anthropocentric conception of disease is not scientifically tenable and is one of which we can at most make use to impress public functionaries and sanitary police. - Schleich has in a somewhat different way concisely described disease as " a form of the struggle for existence against those injurious influences to which man is not yet adapted." The process of adaptation to these injurious influences, however, has for thousands of years been decimating the human race, and the nation and the community are often robbed 
of their most worthy members, while the more worthless individuals prove to be adapted; infectious diseases do not remove with certainty merely the anti-social elements of the community, while leaving and bringing to maturity only the socially useful. Hygiene has accordingly undertaken the task of removing these injurious influences. This reform may be brought about either by making war upon the disease germs, or by combating those conditions of life which are of importance for the disposition either of man or of the parasites, or which have an influence through the fact that they make possible the transmission of the parasites to man.

Measures of hygiene bearing directly on the cause may be applied to different links of the chain to prevent its closing, that is to say, to prevent the outbreak of disease in individuals or groups of individuals. In this method of contest with disease many more things prove useful practically than might be theoretically supposed, and pure reason needs to be supplemented by practical common sense. Experience has certainly a word to contribute. Since detailed considerations belong to the more restricted province of hygiene, I shall simply make some brief statements, for the sake of completeness, to illustrate the in- 
fluence of the scientific conception of bacteriology upon the improvement of individual and national health.

The removal of the predisposition to disease is the most thorough-going way of making all infectious disease impossible, and in this direction much practical advance has already been made. It seems to me, indeed, that in demanding full consideration for this question, hygiene carries within itself a powerful educative force for social healthfulness, the significance of which for the future hygiene of the race can perhaps hardly be divined. This force, however, can make itself fully felt only through the medium of a general sanitary education. In the preceding century and in the first half of the present century, J: P. Frank, Hallé and Lévy attempted to bring this about. Men were to be observed like hot-house plants and only the hypochondriacs were to be grown large; they were to eat only with the balance and control the amount of their drink with measuring glasses,-in the chemical, not in the Munich sense,-they were daily to ascertain their temperatures with the thermometer in order that no mistake might be made. Education to a state of panic is not a wholly new discovery of the Kochian bacteriology, and the earlier products of the 
scare system are certainly just as ridiculous and disgraceful as the newest. The hygienists of the older physiological or clinical schools were far surpassed in hygienic tact by true teachers like Basedow, Rousseau, Salzmann, Guts Muths and Jahn, and among these we may also reckon Frank, who maintained that the healthy youth must be kept habitually in good condition and made physically hardy. A true hygienic education, for the attainment of which the great physicians recommend cleanliness, temperance and work, can never lead to effeminacy and fear of disease.

This is not the place to enter into a consideration of details, the more so since I once discussed many of the points in question in connection with the totally neglected hygienic and national aspect of the woman question. In our cities much mischief is generally done by the notion that florid children are healthy children. The florid appearance is often merely the result of a qualitative overfeeding. Especially in well-to-do families in the city, children are generally nourished with a diet too rich in animal proteid, and to aid the digestion and deglutition of this food, the very dangerous poison alcohol is used in the form of wine, beer and even brandy. But even where conditions are unusual children generally' cannot help 
drinking too much, especially when eating, although if the food is properly prepared no drink is usually needed while eating, and children at first resist instinctively the bad example set by their elders in this matter. The action of the gastric juice and the other digestive juices is impaired by much drinking, and the specific weight of the body is diminished. An over concentrated form of nourishment on the other hand causes peculiar chemical bodies to accumulate in large quantities in the intestine; these are taken up into the circulation and act injuriously as self-poisons or leucomains and as substances inducing fatigue, and at times may even bring about grave manifestations of disease, such for example as are recognized in tetany and coma. Such an overconcentration hinders also the mechanical development of the digestive organs, especially of the stomach, so that the adult takes as small a portion of food as a child. Many ladies afford astonishing examples of this condition, through their efforts to remain slender and interestingly pale by taking a very small quantity of food. A child naturally eats a large quantity of food in order to accustom its digestive organs to the quantity needed later by the adult and to properly develop the capacity of the stomach, and an increase in quality and 
consequent falling off in quantity works little more than injury. Coffee, tea and alcohol are no drinks for children. The story of the youth who when questioned as to the virtues of the old Germans declared them to be "Treue, Wahrheitsliebe und-Gastwirthschaft" is in perfect accord with the present customs of both children and adults. Our educated youth, instead of fuddling themselves and killing time in smoky rooms with skat-playing, would do better to develop themselves in mind and manners and to keep the body strong by gymnastics, sports and athletic games. I need only mention this to call attention to a common error of omission. The body that is trained and hardened by exercise is more resistant to disease in general, as Pettenkofer and G. Jäger have shown. The flushing out of the body by training, with the consequent increase in its specific weight, is, as G. Jäger rightly remarks, an important method of obtaining immunity. To the same end a proper habituation to the feeling of thirst is very important, because otherwise this feeling leads to excess in drinking, and to drinking at the wrong times. The regulation of diet in training in the more limited sense should never be carried out according to a fixed scheme. The human being does not possess like the carnivora, degenerate 
sweat glands, and consequently large and sudden losses of water from violent exercise have a different effect upon him, and the kidneys are thus often seriously injured through ignorance. Many bacteriologists taboo raw fruit and salad, and this precaution may be wise, particularly if, as Lahmann recommends, qualitative consideration be given to the salts in the food, specially to those occurring in green vegetables. I have found that in training very remarkable and uniform changes occur in the relative proportion of the most important salts in the urine as compared with the proportion appearing in a condition of rest or of light work; the amounts of urea, uric acid, and phosphoric acid are affected in very different ways, a condition that indicates a profound alteration of metabolism and must surely exert an influence upon heart and kidneys if proper precautions are not taken. These extreme degrees of metabolic disturbance are connected with the ordinary conditions of life throigh all possible intermediate stages. The place of habitation as well as the nourishment must be carefully looked after. These things may all be learned in a properly directed education just as easily as table manners, so that they become as it were instinctive. There is no greater folly than to change suddenly an 
accustomed and perfectly suitable method of nourishment because of fright at the outbreak of an epidemic.

In contrast to presumably unreasoning animals, the human being, who is supposed to be capable of reasoning, has frequently, strange to say, behaved himself most foolishly in the matter of food and has accentuated this fault by his lack of sense in the matter of drink. It is everywhere observed that the misuse of alcohol increases the danger of cholera infection, and if, as H. Weyl believes, brewers are exempt from this rule the fact may well be due to the circumstance that people of this class are picked for their vigor and are large eaters. Where inordinate abstemiousness exists as the result of poverty, the trouble may be remedied by proper interposition, as is seen for example in the success which has attended the feeding of poor school children. Hunger is a powerful aid to cholera, and it may well be supposed that the first pandemic of cholera, so pregnant with ill for the future, arose from the circumstance that the seemingly insignificant endemic disease happened to coincide with one of those great famines that occur in India from time to time.

The whimsical misconceptions about such matters which usually prevail among us in 
times of cholera epidemics have, with reference to the wretched conditions that existed during the cholera epidemic at Hamburg in I892, been well characterized by Else Hueppe: "Whoever wished to eat, drink and live strictly according to the way prescribed must almost forego the habit of eating and drinking, must change his whole mode of life without receiving anything better in exchange. This necessarily leads to the greatest absurdities. Of what use is it to recommend spring water or red wine to a man when he has only bad brandy with bad water? The thirsty man drinks even out of a pool! What is a poor devil to think when he hears of investigations upon the relations of the comma bacillus to caviar or to tropical fruits while he is hardly able to obtain a piece of bread or a potato ?"

We need an education in hygiene which shall not inculcate the fear of disease; such an education is both an individual and a social question and sharp separation of the two is simply impossible. As with the individual the sins of the father are visited even upon the fourth generation, so social ills affect the innocent together with the guilty. The minors, individual and social, need our protection against commercial exploitation and need also a hygienic protec- 
tion. The warfare against social misery means also protection to the well-to-do upon a side on which they are themselves powerless. It is undoubtedly possible, by the bettering of our ways of life and by the hygienic education of the community, to diminish greatly the sum of predisposition to disease and to heighten the immunity of the whole people. Personal and public measures of sanitation, thus understood and administered, constitute also a form of racial hygiene deliberately conscious of the end to be secured. The actual solidarity of the interests of all classes of people and a knowledge of the practical limits of egotism will gradually bring to maturity more practical social hygiene than any appeal to our sentiments of humanity.

Among individual measures of this character cleanliness may claim an altogether special place, that cleanliness which the Englishman. says is health itself, and which I have declared to be the first and better half of disinfection. But in this respect, also, education must lay the foundation. It must be a thing taught in the common schools, in the factories and the workshops; in the army it has already achieved great success. I think that Else Hueppe grasped the kernel of the matter when with reference to the terrible social misery which 
the Hamburg cholera epidemic revealed, she acknowledged that the better situated individuals were raised quite by themselves above the surrounding uncleanliness but added "When, with the present facilities for compassing cleanliness, filth continues to exist, the general conditions of life must be at fault and for that reason, in such an unclean locality, there is always found diminished resistance of the body toward disease. This fact helps to explain somewhat more adequately than any onesided consideration of disease germs and contagion the difference in resistant power which is so strikingly to the disadvantage of the poor. The disease germs are certainly widely disseminated in any epidemic, and some doorway by which contagion may enter is to be found everywhere. But in the case of the well-to-do the main avenues of entrance are for the most part warded better than among poor people because the whole bodily organization is in better condition."

In this education to healthfulness, just as in Brehmer's method for the cure of tuberculosis, no regard at all is taken of the disease germ ; the predisposition of the man alone is kept in view and this predisposition is acted upon by means of those general conditions of life of which I have made mention earlier, so 
that the intentional modification of these conditions of life may affect the predisposition toward disease. The microbes that are present in any given locality may be able, as already pointed out, to act in such a way as either to heighten or diminish the predisposition to disease, so that in this respect also the influence exerted upon the body may possibly be, and in individual cases can even be demonstrated to be, a particular example of the action of external conditions.

Along this line of hygienic education, in addition to a comprehensive supervision of bodily welfare in the schools through gymnastics, athletic sports and games, the controlling authorities should see to the creation and advancement of a system of instruction in scientific and practical hygiene adapted to the capacity of the schoolchildren. There should be, in connection with the instruction in natural history and natural science, instruction in hygiene planned respectively for the common schools, the secondary schools and the professional schools. Starting from the structure and mechanism of the human body and the presentation of its daily needs it is possible to arrive at some understanding of the general conditions of life and so advance from personal hygiene to public hygiene. Along this same 
road the practical importance of self help in cases of misfortune might be taught. And in the Hochschulen and the Seminars, technologists, administrative officers and teachers should find opportunity for familiarizing themselves with the facts of hygiene, each according to his special needs, in order that he may be able to conduct his work in the real service of the people. In this important matter of hygienic instruction Germany and Austria are extraordinarily backward, and are far outstripped by some countries, as for example by Hungary.

Besides the general increase of the power of resistance, that is rendered possible through the use of the measures I have suggested, it is possible to gain an isopathic or specific resistance against certain diseases by means of preventive vaccination. I may refer my readers to the thorough treatment of this topic in the preceding chapter (p. 3I4) and content myself here with a statement of the fact that the old method of vaccination against small-pox by means of cow-pox has, with but slight modifications, stood the test of time. Even the opponents of vaccination now direct their attacks rather against compulsory vaccination than against the inoculation itself, so far at least as they are candid 
and equipped with the necessary rudiments of knowledge. I cannot, however, touch here upon the question in detail and shall simply content myself with reiterating the statement that those countries possessed of a system of compulsory vaccination, that is to say, of an effectual protective inoculation, make such an extraordinarily favorable showing that the opposite condition that exists in other countries constitutes the very best refutation of the opponents of vaccination. In Germany, since the introduction of compulsory vaccination, not as many as one in I00,000 living inhabitants has died of the small-pox, while the mortality in Austria is about 60 and in Hungary about 450 times as great. In Saxony, between I886-I892, 7 I persons died of small-pox; in Bohemia, I9,607.

The more recent work upon protective inoculation has developed no practical result for man. But the work has not been wholly without practical result, since protective inoculation of cattle against symptomatic anthrax may be set down as completely successful, and the protective inoculations against anthrax and swine erysipelas have at least been of benefit to certain districts.

Far more successful up to the present has been the struggle against external conditions 
that favor disease, and in part also that against the faulty social conditions that operate to this end. It is primarily due to the adoption of such measures that civilized states are not now seriously threatened by diseases like cholera.

The betterment of the subsoil by drainage or canalization, and the various modes of removal or destruction of the waste products of human life and habitation have increased the healthfulness of our dwellings and improved the quality of that indoor climate to which city dwellers are inevitably exposed much of the time. Those substances whose soluble or gaseous decomposition products are offensive and diminish our capacity for resistance to disease are removed from our vicinity. The introduction into the animal body of soluble products of putrefaction at the same time with infective material favors infection even in experiments upon animals; with such assistance germs less virulent than the normal are able to bring about infection, and attenuated germs become again infective. Attempts to prove by animal experiments that the gaseous products of putrefaction have a similar effect have not wholly succeeded. But there is this to be remembered, namely, that the animals used in our experiments are accustomed to a very different atmosphere from that which we ourselves 
breathe. Dogs and rats are in part carrion feeders; rabbits, guinea-pigs, rats and mice live crowded in narrow burrows or holes in which such a stench prevails as would nauseate a human being. To conclude from negative experiments that gaseous decomposition products have no influence in diminishing man's resistance to disease would be a gross laboratory fallacy. The man who is accustomed to pure air does in fact become ill in the bad air of the defectively aerated, overcrowded and insufficiently lighted dwelling of the proletarian. The instinct for cleanliness is fostered by such hygienic measures as can be directed to overcoming these improper conditions and the pure air itself affects favorably the respiratory organs and occasions deep breaths to be taken. The practical application of these facts together with, above all, the introduction of pure water has gradually changed into almost universal cleanliness, the uncleanliness that was once prevalent in continental Europe, and that had crept in since the Thirty Years' War. A supply of good water free from all suspicion of infection, removes any direct relations which might otherwise exist between ourselves and the infiltrated subsoil; on the other hand a bad well in the neighborhood might bring us into direct contact with contaminated soil. 
Virchow long ago attributed the immunity to cholera shown by the city of Würzburg to the fact that a good water supply had put an end to the relations with the filth-saturated earth. Dwellings supplied with abundant natural light and with pure air must gradually augment this advantage.

The foundation for these reforms must still frequently be laid by an improvement of the building laws and by energetic measures against dishonest contractors. Care for the welfare of the people has already made progress in Germany. Cities that neglect their duty must, as in England, be legally compelled to it. Unfortunately these very hygienic questions generally receive shamefully inadequate consideration in representative assemblies. Often they are employed for catching votes before the election and afterwards with affecting unanimity are forgotten by all parties." Matters of this kind, in which all classes are concerned in an equal degree, are not well adapted for placing one's favorite party in a superior position, hence the subject is dropped altogether. Unfortunately many physicians have shown themselves even more backward in such matters than the administrative officers. And yet there is hardly anything more full of import for the people at large than 
the national health, for physical well-being affords the indispensable basis for all efforts of a social and national kind. No civilized continental state yet possesses a central official board of health, and we have not yet obtained very much benefit from the advisory boards which do more for the decoration and glorification of the administration than in really safeguarding the national health. When by the aid of hygiene the efforts of physicians have reached their culmination, and prevention of disease is recognized as better than cure, then in the spirit of our modern striving after the social ideal we must turn also to the urgent task of reforming our Health Departments in accord with the theory and practice of public hygiene. The hygiene of the community afforded us our first and most useful social institutions; in this field has been proved the possibility of accomplishing great social undertakings, and, in contrast to the almost exclusively bureaucratic treatment of social questions in parliament, we have here made substantial gains. None the less, hygiene has not yet obtained the place belonging to it in sanitary administration. The latter, instead of being always prepared to act in the spirit of preventive hygiene, for the most part plods on in the good old way with "fresh emendations to the appendix of the 
modified supplement of the most recent provisional administrative instructions."

While the conditions predisposing to disease which are met with in faulty social conditions and in the general substrata of life, such as air, water, soil and food, act chiefly "upon the human susceptibility to disease, and the improvements made in these particulars diminish this susceptibility, they act in part also by affecting the dissemination of the disease germs. This fact was known long before the days of bacteriology through data of the weightiest kind furnished by epidemiology. In all these matters, however, bacteriology has made us more certain of our ground. Formerly we could, if we wished, assume with Pettenkofer that cholera was not spread by drinking-water, and could quietly omit reform in this matter from the order of the day. I maintained in I889, with the unanimous approval of the German association of water technologists and of the international congress of hygiene at Vienna, that the once insoluble question concerning proof of infection with drinking-water after the outbreak of an epidemic is now a superfluous one, and that we are in a position to convince ourselves beforehand at any moment whether a given source of water makes infection at all possible. We 
are able now in every case to close the well before the child has fallen in ; we need not delay action until an epidemic makes its appearance. In I892 Hamburg was scourged with cholera for its negligence about water-supply, yet that harmful consequences were likely to flow from this neglect had long been predicted by all physicians and technologists capable of judging in the matter. Applied correctly and sensibly bacteriology is certainly able to assist our insight into such questions and a science of hygiene minus bacteriology is simply impossible. In our estimation of external conditions according to their ability to spread infectious disease, bacteriology has afforded great service, and our former inability to judge of these relations from the standpoint of the possibility or impossibility of infection has already given way to a true advance in the direction of a practical preventive hygiene. To be sure, little legislative attention has yet been paid to this point, and the legal regulation of the water question which was urged by me at the international congress of hygiene in Vienna in I887 still remains unaccomplished in spite of the fact that I brought up the matter anew in London in I89I and in Budapesth in I894, and again proved that such regulation could be enforced. The sentiment that attaches 
value to the sanitary welfare of the whole community is for the most part lacking in our government. We almost always refrain from expending at the right time some thousands of dollars, and then when an epidemic is precipitated in our midst we sacrifice millions in paralysis of commerce and manufactures, as Hamburg was forced to do in I892.

The outlook is less promising in the matter of the immediate conquest of the disease germs. The Pasteur-Tyndall-Miquel period when the air was supposed to contain clouds of bacteria was followed by the Kochian era when all fluids were declared to be infected, when stationary and transportable cuspidores were devised, and when the disinfection nuisance reached an unprecedented height. In this latter period an imperial decree dealing with infectious disease was promulgated in the form of a law for safeguarding the people by means of penal enactments ; to execute this law one half of the 'people of Germany would have to be changed into guardians of the other half to preserve them from harm or to watch them during their imprisonment for misdemeanors - with the exception of the children, of course, who already have guardian angels.

The general works of sanitation, whose relations to predisposition to disease have been 
already set forth, may prove also of value through their action upon the disease germs. By improvement of air, water and soil and by control of the food supply the dissemination of disease germs can be restricted and even prevented. In this respect bacteriology has often led to a correction of the practice of earlier times and has especially strengthened in essential points the simple methods of procedure in vogue in England.

Disease germs that have somehow found their way to the deeper layers of the soil may probably maintain their vitality for years since they are there withdrawn from competition with saprophytes, and the absence of air together with the presence of moisture favors the continued existence of the germs without permitting their multiplication. In this way may be explained the fact that, according to the statement of Dönitz, cholera at one time. broke out in Japan among soldiers who were reinterring properly the bodies of their fellows who had died from cholera the year previously and had been buried in a common grave. Similarly cholera broke out in a single street in a small city of Nassau when excavations were going on in the street the year after a cholera epidemic. In cases of this kind proper sanitary measures at the outset would have 
prevented subsequent resurrection of the disease germs.

Works of sanitation have also the effect of interfering with the food requirements of disease germs. In pure soil or in good water the disease germs either cannot multiply on account of the competition of the common germs of putrefaction, or else they adapt themselves to the new and unfavorable conditions of life and suffer loss of their virulence and infective power; that is, they lose their ability to attach themselves to man, to multiply and to form poisons and they finally become again simple saprophytes. Until recently comma bacilli in water were always sought for in vain, but after the cholera outbreak of 1892 and I 893 the bacilli were found in many places and were often present in abundance in the rivers Elbe, Spree, and Seine. These comma bacilli possessed characteristics of such a kind as to cause them to be naturally regarded as cholera bacilli modified and rendered more saprophytic by an aquatic existence. It is to be borne in mind in this connection, to be sure, that individual germs may escape this process of adaptation; but the purer the soil or the water, the less does any such conserving influence come into play and the greater are the chances that the disease germs will succumb in one way or 
another. Virulent germs may persist longest in the slime at the bottom of lakes and rivers because in such places abundant food material exists together with restriction of the air supply.

The competition with the bacteria of putrefaction to which disease germs are subjected acts in such a way that even in cesspools and dungheaps disease germs perish as a rule, so that practically the disinfection of such localities is to say the least needless. It only exceptionally happens that the emptying of a cesspool is followed by an outbreak of typhoid fever. Such a proceeding as the application of milk of lime to manure heaps affects sensible people merely by exciting their sense of the ridiculous.

Works of sanitation are effectual also in a more indirect way. The human being who has become immune through their agency may himself have such an influence upon the invading parasite that the virulence of the latter becomes diminished. The virulence of disease producing bacteria maintains its force or may even be increased in susceptible animals, but generally decreases and may disappear in the process of adaptation to resistant or immuue animals, a fact that was first established by Pasteur (cf. p. I 75).

Works of sanitation act upon saprophytes 
as well and interfere with the dangerous forms of proteid putrefaction which play a rôle in intoxications and are of importance in the ontogeny and phylogeny of parasites, and they do good service also by favoring beneficial forms of decomposition and oxidation, such for instance as the process of nitrification or formation of saltpeter in the soil. In this way also they diminish the possibility of an adaptation of saprophytes to parasitic conditions of existence; they diminish, that is, the likelihood of the origination of new infectious diseases. There is hence no question that works of sanitation do exert an influence upon the disease germs, although this influence has not the high importance which we must attribute to their effect upon human predisposition toward disease.

Human beings may still be counted, and, as individuals or groups of individuals, are amenable to treatment, but such is not the case with the milliards of disease-germs. An attempt to overcome the plague of flies by killing the individual flies would justly be laughed at, and yet there have not been wanting bacteriologists who à la Zacherl would take arms against the individual bacteria and try to fell to the ground every single bacillus.

In localities where the danger from fire is 
slight we may build our houses of wood and thatch them with straw. Where, however, the danger is greater we must build our houses fireproof in order that when one house takes fire a whole district shall not burst into flames. Compared with the quality of material the measure of extinguishing the separate sparks is of less importance in preventing the spread of the conflagration. The method of spark chasing does not help much in the case of buildings of wood and straw, as can be seen in out-of-the-way villages, or even in Scandinavian cities which are still built wholly of wood. The satisfaction of afterwards seeing the incendiary caught and punished helps no one to regain his property. The extinction of sparks will always be less valuable service to the civilized community than the intelligent construction of the house and the adaptation of it to existing conditions.

The combating of infectious diseases by warring directly with the disease germs, the socalled method of disinfection, must be kept within reasonable limits and employed only where we are able to assume that disease germs really exist.

It may facilitate our understanding of this simple demand,-which I advanced in I889 in opposition to the standpoint of Koch, at that 
time extreme,-if I remind my readers that the antiseptic method of treating wounds, devised by the genius of Lister and aimed directly at the germs present in the air and alighting upon wounded surfaces, is carried out to-day only in a rather small number of cases. Operative medicine, taking up again a method introduced by Semmelweiss in 1847 and improved in accordance with the spirit of the times, now generally prefers to proceed aseptically from the outset, and to rely, and with greater success than by the other method, upon the natural aids man possesses against his small foes.

My conception of disinfection is similar to this. I would use methods of disinfection only for the purpose of preventing disease. What disinfection cannot accomplish in this way it cannot accomplish at all, as we ought to have learned by this time. Whoever expects more of disinfection than this deceives himself and others, and leads to an ill-advised expenditure of money which might be better employed in effective works of sanitation.

But even where it is really possible to disinfect with an appearance of success, disinfection does not accomplish anything save where it is associated with cleanliness. Under the influence of Koch, people became accustomed 
to the idea of being able to disinfect without much ado, and Flügge expressed himself very positively in regard to the old conception that attached importance to simple filth as provocative of disease. The view held by Koch quickly burned itself out. We are able to-day to convince ourselves easily that Koch's conception is largely mistaken. Years ago I defended the contrary view in the words: "Disinfection is successful only where cleanliness is associated with it. Cleanliness is the first and better half of disinfection." The great disinfection nuisance of 1892 brought the real necessities of the situation again to the realization of a wide circle. At that time even the health department at Berlin, which is conducted under the influence of Koch, had to admit that: "Cleanliness is better than poor disinfection." It is to be hoped that a step further will be taken, and that the authorities will conclude not to disinfect at all except where there is abundant prospect of success. If we proceed along the line I have suggested, directions for disinfection need not be so long that we forget at the end what we read at the beginning, and they will cease to be official guides to abject panic and fear of bacteria.

Unfortunately one question remains but partly solved. In the recent cholera epidemic 
in Italy in the last decade, and again in 1892 , and in one instance also in Germany, the instructions to admit foreign goods only when disinfected were followed literally, and imported disinfectants were disinfected. Now the question is, are such disinfectants disinfected and made impotent by disinfection or is their efficacy increased?

In the presence of infectious diseases in the neighborhood or in one's own family, disinfection of the body of healthy individuals may be brought about by perfect cleanliness obtained by the use of warm water and soap; in case of direct contact with contagious disease there must be added the washing of the hands with sublimate or solveol (neutral cresol). Only the germ containing substances given off from the sick, such as sputum, vomit or excreta, all of which should be kept in a moist condition and therefore collected in vessels containing water, need be treated with disinfectants of a kind specified as suitable by the physician or prescribed by the local authorities. Such disinfectants are carbolic acid, solutol (alkaline cresol) or fresh milk of lime. The vessels are then to be emptied into the privy where the bacteria of putrefaction will care for the remaining germs more effectively. As regards many of the details of the earlier and mistaken methods of 
THE PREVENTION OF INFECTIOUS DISEASE. 433

disinfection, a searching criticism supported by abundant material will be found in the section by Else Hueppe in our work upon the cholera epidemic in Hamburg in I892, entitled, "On the personal care of health and the nursing of the sick." Many hospital managements have already improved their instructions in regard to disinfection according to the suggestions contained in this paper.

Disinfection of the linen of the sick may be accomplished by isolation and collection of the several pieces in a tub of water, care being taken to control spilling. The individual pieces are then rubbed on the soiled places with soft soap, and the linen is rinsed out in cold alkaline soap solution and well boiled. By this process disease germs are destroyed. If the linen is first placed in a steam disinfecting apparatus the specks of dirt become fixed and the value of the linen is impaired. Disinfection of linen by steam is therefore to belimited to cases of necessity. On the other hand mattresses and articles of clothing, and, when possible, furniture, should be disinfected in the steam apparatus.

Daily disinfection of the sick-room should, apart from the essential measure of admitting fresh air and sunlight, be limited to wiping with a damp cloth the dust from the lower 28 
parts of the walls, from the doors and from the floors. After the sick-room is vacated or after death has occurred, it is best to leave the room undisturbed for some days in order that the germs in the air may settle down. Then the dust may be removed from the floor and the lower part of the walls with a moist cloth; after that, if need be, the floor and woodwork may be wiped with a disinfectant. Carpets may be cleaned with bread; the particles of dirt and the bread-crumbs that fall off should be carefully taken up in a moist condition and burned; calcimined walls are to be covered with a fresh coat of lime-wash when it is necessary. The best means of disinfection however are always to be found in light and air. Pure outer air attenuates to a state of impotency the germs present in a room. He who successfully attacks the dread of light and fresh air, and effects corresponding improvements in building construction, accomplishes more for an effectual disinfection than he who torments himself with the ordinary methods of disinfection and the inundation of dwellings with disinfectants.

Again, in the separation of the sick from the well we often overshoot the mark, and the compulsory conveyance of the sick from dwellingplace to hospital is frequently very injurious. 
In Hamburg the transportation of cholera patients from their miserable dwellings to a good hospital at some distance was not borne very well by the patients; on this account the mortality in the hospitals was greatly in excess of the average mortality. The psychic disadvantages also are frequently quite considerable and the abolition of humanity by bacteriology seems to me a step backwards. I discovered, - and the discovery has subsequently been several times confirmed,-that cholera convalescents, even after they have perfectly regained their health, may still harbor cholera. germs for weeks; and according to Rumpel, both during and after an epidemic, completely healthy individuals may harbor such germs ; diphtheria convalescents also may for months carry about diphtheria bacilli, and this may occur too in healthy individuals. On account of these facts compulsory isolation upon the basis of bacteriological findings may lead to the greatest injury. It has been shown by actual examination that it is highly improbable that any considerable number of new contagions follow in the train of those healthy individuals and convalescents in whom bacteria are found. The imprisonment of healthy and convalescent individuals is an inadmissible restriction of personal freedom. 
The ways in which disease is generally disseminated speak also against bacteriological excesses. In India mere removal of the place of encampment has always proved an important means of protection against cholera and such removal does not threaten the new neighborhood with the disease. The German military hospital at Metz has acted upon the surrounding conditions of health only in a favorable way and has not conduced to the spread of typhoid fever and diarrhœa.

In diseases, too, of the character of scarlet fever we have, to the delight of the martinets, done too much in the last decade in the matter of isolation. In all these matters, after giving bacteriology its due, greater value must again be attached to medical experience. The advance in the science itself has frequently led to a change of view from the extreme claims of Koch and has confirmed the wisdom of the moderate conceptions of the English. In most cases bacteriology has led us to the same conclusions as epidemiology. A method of combating disease which does not adjust itself to our modern social conditions both industrial and social is worthless from the beginning. The colossal injury to trade and commerce wrought by cholera in I 892 abundantly showed that the way of fighting disease then employed 
does only harm, while a preventive method is perfectly feasible and would not paralyze the industry of the country. Control of cholera by a milder system has proved to be the only truly effective proceeding.

The campaign against disease germs and their diffusion is not without good prospects of success. This campaign must be directed also toward securing the prevention of disease, since we are limited by social conditions in attempting to apply the method,-more correct in principle,-of the destruction of the predisposition to disease. But the campaign against germs can succeed without involving us in any trenchant resistance to the modern social order. It is the duty of really civilized states to create conditions suitable to aid in this undertaking. This duty consists in the reform of the sanitary conditions upon the basis of the theory and practice of public health. "It is," says Sonderegger, "a momentous error to believe that any sanitary police system, no matter how carefully conducted, can be of any use where practices conducive to the public health are neglected."

${ }^{1} \mathrm{~A}$ most disgraceful case of the application of extreme bacteriological notions to the combating of disease may be found in the fact that a few years ago even half-civilized and barely tolerated miniature states of the east like Bulgaria had the effrontery, on the breaking out of cholera, to impose a scandalous blockade against the large European states. 
But just because these solid foundations are frequently lacking and because the circles of government officials are not yet in full possession of the facts, the ministers of finance, empowered to make the great expenditures of civilization, do not wish to disburse much money for this purpose, and in our municipalities more politics than political economy is practiced. Upon the continent of Europe the authorities are very quick to adopt sanitary police measures and mutually supporting ordinances. Police regulations are especially welcomed in those places where the will and the creative capacity for social reforms are lacking. By such measures, however, attention is merely directed to the fact that a sanitary organization on the basis of hygiene and adapted to the need of the times is still an urgent want.

A simplification of the statistics of sickness and death is an imperative step in the accomplishment of any measures of reform. This can only be brought about by the help of practicing physicians. For this purpose the schemata must be very concise and no difficulties in respect to their transmission by post should be imposed. Especially in times of epidemic physicians have more to do than to satisfy the curiosity of red-tape statisticians. 
Physicians have no energy or time to be wasted in doing a favor to the association for the benefit of paper manufacturers which is so firmly established in bureaucracy. But it is indispensable that by simple participation of the attendant physicians, and by reliable coroners' inquests, a correct and speedy notification and enumeration of the cases of infectious diseases be made possible, while the interference of official physicians in private affairs is entirely inadmissible and contrary to our Germanic notions of law. Even legislation must make allowance for the awakening recollection of our own nationality. Those fine times are past when the appointed authorities were able to direct the local physicians to cause the epidemic to cease since it had lasted long enough.

In spite of this progress the administration is still guided too little by actual conditions. A gratifying change of opinion however, in which we see at work the influence of bacteriological discoveries, is already to be noted. That the prevention of infectious disease by combating the cause of the disease is a great social achievement cannot be denied. 


\section{CHAP'TER VIII.}

\section{THE HISTORY OF BACTERIOLOGY.}

MEN justly attempt to understand what at present exists by considering the manner in which it has come into existence, and we are hence in the habit of drawing up an historical outline of any subject we may be carefully considering. In bacteriology, however, we have been for some time engaged in a complete revaluation of our data. The old facts remain, but new facts have been added to them with the result of bringing to inaturity new theories. These have either not conformed at all to ideas generally received or have perhaps fallen in with older views which had been apparently set aside. Under such circumstances it is best first of all to learn to know the data now at our disposal in order to consider as objectively as possible the facts and theories of an earlier time.

Knowledge of the occurrence of poisonous insects such as mosquitos and tse-tse flies led people of the older civilizations to an ontological conception which set up Beelzebub as the supe- 
rior god or patron of the invisible or visible poisonous flies that brought disease. The Roman writer Varro supposed in like fashion that, as we recognize with the naked eye both large and small insects hovering over the marshes, so insects still smaller are able to exist, and these forms, so small as to be invisible, might perhaps be the cause of marsh fever; previous to this men had usually looked upon emanations or injurious gaseous substances as the cause of this fever. Paracelsus had a dim foreshadowing of the truth when he spoke of the "seeds" of disease. The Jesuit Kircher, from observations upon the process of putrefaction and the worms which made their appearance in the course of this process and which he observed with a poor little microscope was the first to develop in a very comprehensive fashion the theory of a "contagium animatum" (I67I). Van Leeuwenhoek, the "father of micrography," was, however, the first really to discover the " world of the infinitely little." He worked during the last quarter of the I 7 th century, with the help of a good microscope that he himself constructed, and studied the organisms found in infusions, putrefying fluids, pus and other substances. Among the organisms that he observed and noted were those we now know as bacteria, then perceived for the first time. 
Leeuwenhoek's successors busied themselves with describing and classifying these "infusion animals." Among these investigators are especially to be mentioned v. Gleichen-Russworm (I778) and Otto Friedrich Müller ( I 786), the latter of whom made good drawings, applied many of the names we still use and established genera still recognized. Bory de St. Vincent (I 824) made a further advance, and in I838, Ehrenberg, and in I84 I, Dujardin' followed with new discoveries, which were added to in 1852 by Perty and in 1853 by Ferdinand Cohn. In opposition to their predecessors these later investigators reckoned bacteria among the true plants and Perty clinched the demonstration by the discovery of endogenous spore-formation.

Cohn sought to develop the systematic classification of bacteria. He carried out a system of separation into many genera and species, laying stress upon the differences observed. Perty recognized clearly the occurrence of a variation in form according to the substratum, whereas before this there had been simply a general recognition of a Protean-like change of form.

From the time of Kircher onward, the doctrine of a "contagium animatum," went hand in hand with the amassing of this systematic 
knowledge. Among others Lancisi, Réaumur, Linne and Plenciz gave their adhesion to the theory, Plenciz in 1762 advancing comprehensive reasons for it. The investigations of Pringle upon infectious diseases and disinfectants also belong to this period. The doctrine, however, soon became discredited, because of the growth of the opinion that not merely the causers of disease were alive and parasitic, but the diseases themselves were parasites; names like lupus and cancer still remind us of this. Of even greater influence was the fact that the study of pathological anatomy under Malpighi, Bichat and Virchow busied itself only with the consideration of the anatomical changes in disease, and lost all comprehension of the outside factors. This went so far that only in 1874 did Virchow express a very restricted recognition of the parasitic theory of infectious disease.

The question how far microbes are concerned in the processes of putrefaction and fermentation approached the matter on quite another side. Some asserted that the infusoria and moulds on account of their ubiquity

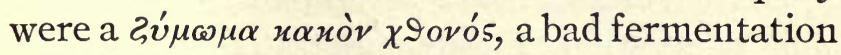
product of the soil, originated by spontaneous generation, while others derived them legitimately from germs of the same kind. Micheli 
succeeded as early as I 729 in cultivating many moulds from spore to spore. So far as the smut and rust fungi were concerned, however, origin by heterogenesis seemed still possible till in r8or, Persoon, and in r853 De Bary solved this question finally. The notion of the spontaneous generation of insects was overthrown by Swammerdam (I669) and Redi (I688), so that the supporters of this doctrine were forced to have recourse to still smaller organisms. Needham believed that he could prove experimentally the spontaneous generation of "infusion animals" and his conclusions met with general assent for a time, but Bonnet (I762) and Spallanzani (I769) overthrew his claim so completely that Appert (I8o9) was able to devise a successful method for the preservation of food materials on the basis of theirwork. This was the first practical result of the older bacteriology. New opponents continued to arise till Franz Schulze (1836), Schwann (1837), Schroeder and v. Dusch (I854-I86I), van der Broek (I857) and Pasteur (from I 857 onwards) overthrew by conclusive evidence every argument for spontaneous generation, and demonstrated that all microbes arise by legitimate descent out of germs of the same kind. The doctrine of spontaneous generation became in the hands of Béchamp 
the doctrine of microzymes, that is of the origination of active granules in the living organism; in the hands of Wigand it became the doctrine of the anamorphosis of protoplasm, that is, of the transformation of higher cell protoplasm into bacterial protoplasm; and in those of Fokker, the similarly conceived doctrine of heterogenesis. The kernel of truth in the whole matter is that there really are cellular elements whose activity lasts longer than the life of the cell. A11 the effects of this sort are in the same class with the power manifested by the "active" proteid secreted by the gland-cells in the form of the solvent enzymes; these enzymes often appear as cell granules which have outlived the cell and have become independent, but they only display part of the cell activities, and are not capable of forming new cells.

If the "infusion animals,"-and in this group were included the organisms we to-day call bacteria,-could not arise in albuminous fluids by spontaneous generation, but could spring only from germs of their own kind which had somehow made their way into the fluids, then on the other hand it must be assumed that the germs in proportion as they multiplied would evoke various decompositions by virtue of their life activities. This was 
shown by Astier in $18 \mathrm{I} 3$ in regard to the yeasts, and by Sette in I8I9 in the case of the microbe of the bleeding host, but Cagniard de Latour and Schwann were the first to succeed in bringing proof for this view and proof which was of so satisfactory a kind that Turpin in the following year attributed all fermentations to the life of microbes. These experiments were in I84I supplemented by Fuchs with experiments upon blue milk, and again by Remak in I84I, and Mitscherlich in I84II843, each of these observers finding different kinds of ferment organisms in different fermentations. Helmholtz in I843 made important observations upon the germs of putrefaction. It was however in the years following I 857 that Pasteur finally established the truth of the view that all processes of fermentation and putrefaction alike are caused by living things, and that in each different fermentation different kinds of microbes are concerned. The specificity of the ferment germ appeared according to his investigations to be the cause of the typical specific fermentations.

Goeze and Bremser's study of the development of tapeworms afforded insight into the cause of tapeworm and pinworm diseases. Then Prevost ( 1807 ) discovered that moulds are the cause of many plant diseases, and this 
work reached a positive conclusion when De Bary proved that parasitic moulds occurring upon different plants, and till then regarded as different species, belong in the cycle of development of a single species, and showed that such a change of host or heterœcism took place among the rusts or Uredineæ. Bassi and Balsamo discovered in 1835 (published in $\mathrm{r} 837$ ) that the disease of silkworms known as muscardine is caused by a mould, and Audouin found that this mould forms spores, by the help of which the germs of the disease live through the winter and are able to spread the disease anew the next year. Schoenlein discovered the mould that causes scald-head in I839. At the same time the itchmites were discovered anew.

On the basis of these discoveries regarding the processes of fermentation and disease, Eisenmann, and still more acutely Henle, again urged (r840) the doctrine of a contagium animatum, and with such success that in spite of Virchow's opposition the doctrine henceforward never disappeared from the order of the day. Another thing contributed also to the establishment of this doctrine, namely, that the need of assuming external causes of disease was making itself felt among epidemiologists. Pettenkofer especially, from 
I854 onwards, developed the view that a distinction must be made between those disease germs which develop endogenously only in sick men and those which reproduce themselves ectogenously outside of the human body. The experiments begun in 1857 by Semmelweiss upon the prevention of childbed fever by keeping away decomposable substances, and those by Lemaire in I860, who proved that carbolic acid annulled the action only of living germs and not of enzymes, were recognized to be of great importance.

But direct discoveries also were not lacking. Pollender in 1849 and Davaine and Rayer in I850 discovered the anthrax bacteria. The etiological significance of the germs was clearly pointed out by Davaine about I863, and in 1877 Koch, by the discovery of the spores, brought the question to a satisfactory conclusion, as in earlier times Audouin had rendered complete the discovery of Bassi. A similar discovery was made by Pasteur in I 865 in another disease of silkworms, pébrine, which he likewise brought to a satisfactory conclusion by the demonstration of spores. Obermeier in 1873 discovered the Spirochæte of relapsing fever. Von Recklinghausen, Waldeyer, Klebs and Weigert had already found bacteria in the tissues in various dis- 
eases, when Koch in I878 published his investigations upon wound infections. According to his conclusions every special disease had corresponding to it a special disease germ just as there appeared to be a special germ for each fermentation. Pasteur's comprehensive work laid the foundation for the conception that each special fermentation and disease was causally dependent upon a special micro-organism, and Koch's work capped this view just as comprehensively.

This idea corresponded so admirably with the general expectations of a physician brought up on ontological conceptions that in the immediate future the wish became father to the thought. Koch advanced this line of work in a remarkable degree by the methods he devised about I880. The isolation of pure cultures of a large number of micro-parasites was achieved and in many cases it was demonstrated by successful transfer to animals, that the microbes had great significance in the origination of those diseases in which they were observed (cf. Chapter III., p. 87). In this series of investigations, Koch's discovery in I882 of the germ of tuberculosis stands out conspicuously as especially epochal. This is indeed the greatest discovery due to the carrying out of a method which has as yet been 
made in bacteriology. Even the discovery of the cholera bacteria in 1884 by Koch and his co-workers Gaffky and Fischer was of less importance because of the fact that this investigation was not brought to a satisfactory termination; indeed, Lister in I89I at the International Congress in London declared that the etiological significance of the comma bacilli first became admissible through the proof brought by Hueppe of the formation of poison. (That the parasitic bacteria exert their effect through the formation of poison has been set forth fully in preceding sections.) Along this line of work there is as yet no proof that micro-parasites occur as the exciting cause of the typical acute exanthemata like small-pox, typhus fever, scarlet fever and measles. It is certainly striking that the results up to the present time should be negative in just those diseases most markedly contagious, and this is perhaps explicable on the supposition that bacteria are not concerned in these affections.

Enlightenment as to the germs causing malignant tumors, especially the epithelial tumors and among them the carcinomas would be equally desirable. The objects that have up to the present been described as the parasites of carcinoma will not stand criticism. Important reasons, moreover, are adduced for 
the view that these tumors are perhaps not to be attributed at all to micro-parasitic cause, and hence very stringent proof is necessary to produce conviction on this point.

The whole tendency to search out " specific" germs of disease and fermentations is a relic of the natural history point of view. The notion that every specific disease is caused by a specifically constant parasite is in accordance with the ontological wish of many physicians who are thus spared the trouble of further reflection. There is, in addition, the fact that in courses of instruction we are compelled first to convey to pupils in a methodical manner and by concrete examples a general understanding of the contagium animatum. An introduction to the subject matter starts necessarily from the specificity of the microbes. In the brief time at the disposal of most students they usually do not, on the basis of their own observations, pass beyond this stage, so that the courses in bacteriology have aided largely in bringing it about that this ontological and thoroughly unscientific conception of the relations of bacteria to disease has become the common property of physicians. A pedagogical necessity has thus directly contributed to impair the scientific training of physicians.

It is a false premise that the constancy of 
species, the specificity of the parasitic microbes is the cause of disease. As Henle deduced the etiology of disease from the constancy of the specific disease germs, so, in association with Perty, Billroth and Nägeli have just as logically developed the view that the bacteria vary and adapt themselves both in form and action to the conditions of existence. Both investigators overshot the mark, for Billroth assumed the existence of only one pathogenic species which he called Coccobacteria septica, and Nägeli recognized no constant species outside of Sarcina.

Hans Buchner as far back as ${ }^{2} 878$ treated the virulent anthrax germ culturally in such a way that it became impotent; unfortunately in I880 he went still further, supposing, in accord with Nägeli's idea, that by cultivation he transformed the pathogenic anthrax bacillus into the saprophytic hay-bacillus and vice versa. Koch also went too far in his criticism when he assumed that Buchner simply confounded these very different species of bacteria. Prazmowsky and De Bary have found that attenuated anthrax bacteria at times really form pellicles on the surface of fluids like the hay bacillus. It is impossible, however, by cultivation to change one kind into the other, and the 
germination of spores in the two species is very different (Prazmowsky and Brefeld). Nevertheless Buchner intentionally and with a clear understanding of his aim attempted to influence the disease-producing activity of the parasite, which was the factor considered by Koch as causal and necessarily constant, and this result he was the first within certain limits to achieve. A similar result was accidentally obtained in I880 by Pasteur, who found that virulent cultures of the bacteria of chicken cholera become impotent after standing for some time in the air. From this discovery by Buchnerand Pasteur we may date a new period, the scientific epoch in bacteriology. If we are able at will to diminish or altogether annul the most important characteristic of bacteria and the one formerly supposed to be necessarily constant, that is the "specific" ability to produce "specific" diseases, fermentations, putrefactions or pigments, and on the other hand to heighten this power, then we must change our whole conception of causal relationship. By means of artificial protective inoculations such as Pasteur in I880 undertook for the first time with the attenuated bacteria of chicken cholera, the whole realm of experimentation became accessible.

These investigations caused stress to be 
laid again upon the significance of the animal organism in the etiology of the infectious diseases, in predisposition toward disease, in natural immunity and in immunization, although the correct etiological interpretation was not immediately perceived. H. Buchner and Metschnikoff especially furnished important aid in this work, and Hueppe in I893 maintained in a purely mechanical and monistic fashion and in a manner free from all ontology the causal continuity existing in infectious diseases and thus did away with the last remnant of ontology, even in the complicated realm of organic science. In this scientific conception of etiology lies the final reconciliation between cellular pathology and bacteriology, a reconciliation which could not and would not be brought about previously because each of these conceptions in its ontological relations held only its own idol worthy of worship. With the removal of this remnant of ontology went the last reminder of the personifications of priest medicine. The abandonment of every form of ontology makes it possible for medicine to develop in as strictly a mechanical way as any other natural science.

Although medicine has been greatly preoccupied with bacteria, bacteriology has till now exerted only a very slight influence upon medical thought. For the majority of physicians 
it has happened merely that one disease entity, the diseased cell, has been replaced by another disease entity, the pathogenic bacillus. On the basis of such a conception, however, thousands of observations upon healthy and diseased human beings remain irreconcilable and just as little capable of comprehension as before. Only on a conception not ontological, but mechanical or dynamical, forming a part of the monistic conception of the universe, will all discoveries be made more intelligible; and the variable as well as the constant will find its place, the mysticism of ontology having been taken away from both. By advancing this scientific conception bacteriology is qualified to influence medical thought favorably and to render it essentially more profound.

Bearing this possibility in mind the position of scientific bacteriology in medicine and hygiene is sharply and clearly defined. As I have tried to show connectedly in the present work, the striving of scientific medicine after unity finds in this scientific exposition of bacteriology a clear and comprehensive expression.

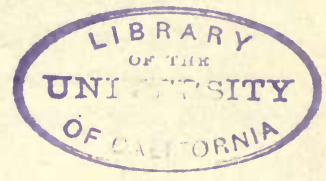





\section{BIBLIOGRAPHY.}

THE large number of bacteriological papers that appear in the course of a year, and the scattering of the records of research in different periodicals have brought into existence certain publications which make a specialty of recording and summarizing all the more important contributions. Baumgarten's Jahresbericht über die Fortschritte in der Lehre von den pathogenen Mikroorganismen is one of the most comprehensive of these, but is usually late in appearing. Alfred Koch's Jahresbericht über die Fortschritte in der Lehre von den Gährungsorganismen covers a somewhat different field, and deals more with the general biological side of bacteriology. The Hygienische Rundschau (bi-weekly), and the Centralblatt fïr allgemeine Gesundheitspflege (monthly) include especially matter bearing on the hygienic aspects of the subject.

The Centralblatt für Bakteriologie, Parasitenkunde und Infektionskrankheiten is the most important aid in keeping abreast of current progress. At the beginning of 1895 the scope of this journal was somewhat broadened, and a division of territory made, the journal being now issued in two sections, one dealing with the medical and hygienic side: Abtheilung I., Medizinischhygienische Bakteriologie und tierische Parasitenkunde (2 volumes yearly, 15 marks a volume); and the other with the general biological and technological side: Abtheilung II., Allgemeine, landwirtschaftlich techno- 
logische Bakteriologie, Gärungsphysiologie and Pfanzenpathologie (I volume yearly, I6 marks).

The chief journals in which the results of original research are published are the following:

Zeitschrift für Hygiene und Infedionskrankheiten (edited by R. Koch and C. Flügge).

Annales de IInstitut Pasteur (Duclaux).

Arbeiten aus dem kaiserlichen Gesundheitsamte.

Archiv fïr Hygiene (Pettenkofer).

Annales de Micrographie (Miquel).

Journal of Pathology and Bacteriology (Sims Woodhead). Journal of Experimental Medicine (Welch).

Many important papers appear also in the various medical journals and in periodicals devoted mainly to pathology or hygiene. Several important discoveries have been first announced through the Deutsche medicinische Wochenschrift.

The following reference manuals and general textbooks may be mentioned :

Abbott. Principles of Bacteriology. 4th Ed., I 897. Baumgarten. Lehrbuch der pathologischen Mykologie, I 886-90.

Cornil et Babes. Les Bactéries, 3d Ed., I 890.

Crookshank. Bacteriology and Infective Diseases, 1896.

Duclaux. Traité de Microbiologie, I., I 897.

Fischer. Vorlesungen über Bakterien, 1897.

Flügre. Die Mikroorganismen, 3. Aufl., 1896.

Fränkel, C. Grundriss der Bakterienkunde, 3. Aufl., I 890.

Günther. - Einführung in das Studium der Bakteriologie. 4. Aufl., 1895 .

$\checkmark$ Heim. Lehrbuch der bakteriologischen Untersuchung und Diagnostik, 2. Autl., 1898 .

Hueppe. Die Methoden der Bakterienforschung, 5. Aufl, , I891. 
Kanthack and Drysdale. Practical Bacteriology, 1895. Klein. Microörganisms and Disease, 3d Ed., 1896.

M'Farland. Text-book upon the Pathogenic Bacteria, 1896.

Migula. System der Bakterien, Bd. I., 1897.

Muir and Ritchie. Manual of Bacteriology, 1897.

Thoinot and Masselin. Précis de Microbie, 3d Ed.,

1896.

Schenk. Grundriss der Bakteriologie, 1892.

Sternberg. Manual of Bacteriology, $2 \mathrm{~d} \mathrm{Ed.,} 1896$.

Woodhead. Bacteria and their Products, 1891.

Works dealing more particularly with the industrial side of bacteriology are :

Conn. The Fermentations of Milk, 1892.

Freudenreich, E. v. Die Bakteriologie in der Milchwirtschaft, 1893 .

Grotenfelt-Woll. The Principles of Modern Dairy Practice, 1894.

Kramer. Die Bakteriologie und ihre Beziehungen zur Landwirtschaft, 1890-2.

Lafar. Technical Mycology. Eng. trans., 1898 .

Migula. Bakterienkunde für Landwirthe, 1890.

Pearmain and Moor. Applied Bacteriology, 1896.

Russell, H. L. Outlines of Dairy Bacteriology, 1894. . Scholl. Die Milch, 1891.

Valuable special bibliographies are appended to the articles on infective diseases in Allbutt's System of Medicine (especially vols. I. and II.). Muir and Ritchie's excellent Manual of Bacteriology also contains references to many of the more important papers on special topics. 



\section{INDEX.}

Abrin, 321, 329, 385, 387.

Actinomyces, 42, 56, 143, 205 note.

Actinomycosis, 204.

Active Proteids, 48, 49, 86, 93 , 98, II8-I 25, 309, 310, 360.

Adaptation, 56 .

Aërobiosis, 56, 62, 96 .

Alcohol (misuse of), 4I I.

Alcoholic fermentation, 57, 59, 207; - of milk, II 7 .

Alexins, 357-377. See Active proteids.

Alternation of generations, 270, 27 I.

Amœbæ, 208.

Anaërobiosis, 50-6o, 96, 97, 178, I8o.

Animal parasites. See Parasites.

Anthrax, I56-160, 261, 266, 302, $308,377,390$; Bacillus of - , see $B$. anthracis; cutaneous $\longrightarrow, 318$; intestinal

- 318 ; symptomatic see Symptomatic anthrax.

Antidotes, 286, 287, 321, 323, 329-33r.

Antisepsis, 68, 72, 430.

"Anti-substance." See Antidote.
Antitoxin, 327-397; diphtheria -. See Diphtheria.

Anti-venin, 385, 388 .

Arrack fermentation, 45 .

Arsenic, 393.

Arthrobacterium, 35, 38, 195.

Arthrospores, 12, 14, 27-31, 36$40,185,365$

Ascococcus, 16, 18 .

Asepsis, 71 .

Aseptol, 76.

Asparagin, 97, 98.

Aspergillus, Oryzæ, II6.

Attenuation, 58, 6o, 6r, 66, 69 .

Bacillus, $23,35,38$; - anthracis, I9, 30, 33-35, 45, 66, 82 , (spores of, $69,72,90$ ), I38, I 56-16o, 261, 266; coli communis, I40, I74, I90, 192, 193, 257; - crassus sputigenus, 172 ; — icteroides, 215 ; megatherium, 30; - mesentericus, I27; - prodigiosus, I3I, I 4O, I 52; proteus, I49, 150 ;

pyocyaneus, I 5O, I 5I, 377;

Solmsii, 32 ; - subtilis, I9, 25, 30, 31, 67, 127 .

Bacteriaceæ, 38 . 
Bacterial forms, ro-13.

Bacterium, 23, 35 ; capsu-

latum pneumoniæ, I72 ; chlorinum, 6I ; - paludosum, 32 ; pediculatum, 45 ; photometricum, 6I; - termo, 25, I27, 130; - Zopfii, I2, I9, 31 .

Beggiatoa, I8, 38, 40, 63, III, II 2.

Black Death, 243.

Black-leg, I8I.

Blenorrhœa, I77.

Blood, bactericidal power of, 359.

Bothriocephalus latus, 270.

Branching, 43, 44.

Bubonic plague, 195.

Building laws, 420.

Capsulated bacteria, I72, I73.

Carbolic acid, 72, 73, 76-78, 83 , $88,90,432$.

Cause, definition of term, 230.

Cell-division, 6, 26.

Cell-membrane, 4,6 .

Cells, structure of, 3-6.

Cerebro-spinal meningitis, I74.

Cheese bacteria, 136 .

Chicken cholera, I62, 300, 319.

Chlamydospores, 29, 34, 43.

Chlorine, 72, 73.

Chlorophyl, 6I, 62, 9I, I03, I07, Io8.

Cholera asiatica, I84-I9I, 243 , 268, 301, 307, 317, 322-324, 339, $390,398,399,4 I I, 425,426$, (Hamburg epidemic, 4I $2,4^{\mathrm{I}} 4$, $423,435)$; poisons of I23, 385; bacteria of $\longrightarrow$, I9, $25,36,43,57,58,60,69,75$,
I 30, I40, 40I; cholera-red reaction, 188,189 .

Cholera nostras, 190.

Cholin, I20, I2I.

Chromatium, 7,8 .

Chromulina, 34

Chrysomyxa rhododendri, 245 ; ledi, 245.

Cilia, 24-26.

Cinnamic acid, 392.

Cladothrix, 7, 8, I5, 38, 40, 42, 44-46, 186.

Classification, Iо, I I, 36-4 I.

Clathrocystis, $16,18$.

Cleanliness, 4 I9, 430-432; teaching of $-4 \mathrm{I} 3,4 \mathrm{I} 4$.

Clostridium, 9, I9, 30-32, 35 , $38,180$.

Coal formation, beginning of, I I 2 II 3, I3O.

Coccaceæ, 37.

Coccobacteria septica, 138

Colon bacilluș. See B. coli communis.

Colonies of bacteria, 13, 14, 16 .

Comma bacilli, 20, 3I, 36, 43 , $60,184,185,189,301,324$, 344,426 .

Constancy, of form, 21, 22, 23 , I26, I39-I 44 ; - of species I $26,137,138$.

Cordyceps, 244 .

Corrosive sublimate, $72,73,75$, 76,432 .

Cow-pox, 299.

Creatin, 392.

Crenothrix, 28, 38, 40; ochracea, III.

Creolin, 78.

Cresol, 77-79, 85 .

Cyanophyceæ, 39, 4I, 64 . 
Cycle of activity, 254, 264.

Cystopus candidus, 245 .

Degeneration forms, 19 .

Deutoplasm, 4 .

Diphtheria, 182, 307, 317, 318, 327,337 ; bacillus of,- 34 , $35,43,263,293,325$; serum, 349, 350, 352-356, 386, 387 ; — toxin, $123,182,316$, 385 .

Diplococcus, intracellularis, 174 ; — lanceolatus, I7r. See Pneumonia, I72, 344.

Discontinuous sterilization, 68 , 69.

Disease, a process, 224 ; parasitic theory of - 227 ; Schleich's description of 404; - stimuli, 25I-272.

Disinfectants, $7 \mathbf{I}-84$.

Disinfection, 68, 7I-90, 430432 ; - nuisance, 424 ; absurdity of,$- 427-429$;

of body, 432; - of linen, 433 ; - of sick-room, 433 , 434.

Disintegration, 20.

Dissemination of disease germs, 422,425 .

Distomum hepaticum, 270.

Division of cells, 6 .

Drinking too much, 408, 409 .

Drying, behavior of bacteria towards, 69, I3I, I7I; behavior of active proteids towards, 88 .

Dysentery, 208.

Echinococci, 270.

Education, hygienic. See $H y$ gienic education.
Electricity, effect of, upon bacteria, 70, $7 \mathrm{I}$.

Emulsin, 39I.

Endospores, 29-35, 39, 40, 42, 64-66.

Energy, relations of bacteria to, 52-55.

Enzymes, 46, 65, 72, 87, 88, 125, 328.

Erysipelas, swine, I6o, I6I, 302, $339,4 \mathrm{I} 7$; bacteria of 263, 303 .

Fermentation, 17-19, 46, 48, 57, 59, 70, 128, 129; lactic acid $\longrightarrow, 134$.

Ferments, digestive, 306, 336, 390 ; lifeless — $47,48,87$.

Fever, 60, 153, 382.

Flagella, 24-26.

Florid children, 407.

Fluorescence, 63.

Formaldehyde, 94, 95, 97, 104, I07, I09.

Form-genera, 34, 35, 126.

Form-species, 34, 35, I 26.

Forms of bacteria, I0, I I.

Friedländer's bacillus, 172 .

Glanders, 206; bacillus of - , 3 r3.

Gonidia, 27, 28.

Gonorrhœa, 177, Fig. 25, p. I6r.

Granules, 3, 4, 26.

Gregarinidæ, 176 .

Hay bacillus, 67, I 27, I30, I34, I52.

Hydration, 52.

Hydrophobia, 315, 318. See Rabies. 
Hygiene, 405, 406, 41 2, 421. Hygienic education, 4I3-4I6. Hyperæmia, 392.

Immunity, 218, 243, Chap. VI.; active and passive - $316-$ 327, 373; natural and acquired -, 3I4-3I6, 374, $39 \mathrm{r}$; influence of nourishment upon -, 394 .

Immunizing proteids, 332,362 .

Inflammation, 391, 392.

Influenza, I74.

Iodine terchloride, 393, 394.

Iron algæ, III.

Iron bacteria, III, II5. See Crenothrix ochracea and Leptothrix ochracea.

Isolation of sick, 435,436 .

Isopathy, $3^{89}$.

Laboulbenia muscæ, 244.

Lepidium sativum, 245.

Leprosy, 202.

Leptothrix, 9, 38, 42; ochracea, III.

Leucocytes, 36I-367, 39I.

Leucocytosis, 390.

Leuconostoc, I4, 3I, 40.

Light, behavior towards, $6 \mathrm{I}$, I07.

Lime, milk of, 432.

Lockjaw, I77.

Luminous bacteria, 62, 63 .

Lysol, 78, 79.

Macrophages, $\mathbf{I} 76$.

Malaria, 210-212, 279-28I, 393.

Malignant œdema, I79-I8I, 307.

Mallein, 312-3I4.
Meningitis, I74

Merista, 170.

Metabiosis, II 7

Micrococcus, 23, 37 ; - amylovorus, 209; — prodigiosus, 26 ; tetragenus, I70; - phosphorescens, 63. Milk, sterilization of, 68,69 .

Motility, 24, 26.

Moulds, 212-2I4, 267.

Mouse typhoid. See Typhoid.

Mucor, 29, II6, 214.

Myconostoc, I4.

Myxomycetes, 208.

Nitrification, 57, Iо9, I 10, 428.

Nomenclature, 23, 36-4I.

Normal serum, 326 .

Nostoc, 40.

Nucleus, 4, 6-8.

Eco-parasites, I69, I7I, I84, I90, 193.

Edema, malignant, I79-I8r, 307.

Oscillaria, 40.

Overfeeding, 407-409.

Oxidation, 53, 55-60, 97, rog, II 2.

Oxygen, behavior towards, 60 , 61. See Anaerobiosis, 62.

Ozæna, I73.

Paraplasm, 4.

Parasites, animal, I76, 269: facultative $\longrightarrow, 255,256$, 269; obligatory -255 ; development of,- 403 ; influence of sanitation upon $\longrightarrow, 400,401$; strict and occasional $\longrightarrow, 400$. 
Parasitic theory of disease. See Disease.

Pasteuria, 17.

Pasteurization, 69.

Perlsucht, 201, 207.

Phenol, 77, 78, 8o, 8r.

Phosphorescence, 62.

Phragmidiothrix, 38 .

Phytophtora infestans, 244; omnivora, 244.

'Pigments, bacterial, 6I-63, 98. Plasmodiophora brassicæ, 209. Plasmodium malariæ, 2 ro.

Plasmolysis, 8, 9.

Plectridium, 30, 35, 38, I78.

Pleomorphism, 43, 44, 46 .

Pneumonia, 339, 344, 390; bacteria of, 6I, I70, I7I, 263.

Poisons, bacterial, 58, 89, Ir8125.

Polymerization, 5I, 52.

Potato bacillus, 25, 67, 127, 134

Predisposition to disease, 242, 266, 295, 40r, 404, 406, 4r 4, 4 I 5 .

Protective inoculation, 389-390.

Proteids, 306, 343; active, 48, 49 , $86,93,360$; passive, 123,124 .

Proteus, 25, r49, r5o, 307 .

Protoplasm, structure of, 3,4 .

Protozoa, 209.

Prussic acid, 8r, 92.

Pseudo-diphtheria bacillus, 184 .

Pseudo-tuberculosis, 20 r.

Pseudo-influenza bacillus, I75.

Ptomaines, $x 18-122,306$.

Pure cultures, 21, 66, 67 .

Pyæmia, 156, I6o, 167, I73; staphylococci, $3 \mathrm{r} 7$.

Pyocyaneus, 150,307 . See $B$. pyocyaneus.
Pyogenic bacteria, I66-I70.

Pythium, 244.

Quinine, 72, 279-284, 393.

Rabies, 303. See Hydrophobia. Reduction, 5I, 53.

Relapsing fever, 175 .

Relationship of bacteria, 40, $4 \mathrm{I}$. Resistance to disease, 26o, 266, 40r, 404, 409.

Rhinoscleroma, I72.

Ricin, 321, 329.

Saccharomyces, 40, 207.

Salicylic acid, 8o.

Salicylicates, 279, 280.

Sanitation, 399-402, 425, 426 ; works of $-, 4 \mathrm{r} 3,4 \mathrm{I} 8,424$, $427,428,438,439$.

Sapocarbol, 78 .

Saprolegnia, 176 .

Saprophytes, 258, 40I, 428; facultative $\longrightarrow, 255$; occasional - 400 .

Sarcina, r6, r8, 37; - septica, I7o,

Scarlet fever, 436 .

Schizophytes, 40-42.

Sclerothrix, 42.

Sclerotinia, 244

Scorpion-venom, 386.

Septicæmia, I6o, I67, 171, I72, 208, 210 ; hæmorrhagic I62; - of carp, r76; mouse - 160, I6r; rabbit —, 3I8, 39I; Vibrio —, 307.

Serum, normal, 326,384 ; curative - $, 383,3^{87}, 3^{88}$; diphtheria - see Diphtheria. 
Small-pox, 243, 244, 296-299.

Snake-blood, 338.

Snake-venom, 329, 338, 385388.

Sodium cresotinate, 79 ; salicylicate, 79 .

Soil, bacteria in, $64,425,426$.

Solutol, 79, 432.

Solveole, 79, 432.

Spirillum, 23, 35, 36, 38, 58, 59; - amyliferum, 30 ; - desulfuricans, I I2; rubrum, 56; - serpens, 25, 30; - undula, $7,8,9$, ro, 29.

Spirobacteriaceæ, 38 .

Spirochæte, 15, 20, 23, 35, 36, 38 ; — of relapsing fever, I75, I 86.

Spontaneous generation, 46-49 Spore-formation, 26-35.

Spores, behavior of to temperature, 64-67.

Staphylococcus, I6, I70; pyogenes aureus, I39, I66, I67 :- pyæmia, 385 .

Sterilization, $67-69$; - of milk, 132, 133 .

Stimulus, to protoplasm, 90, 280-287, 290; disease 'see Disease; Specific stimuli, 389, 395, 396.

Streptococcus, $37,357,386$; — pyogenes or erysipelatos, 167-170.

Strychnine, 393.

Sulphur bacteria, III. See Beggiatoa, II 5.

Suppuration, 262, 263. See Pyogenic Bacteria.

Surra, 209.
Susceptibility to disease, I 47 , I69, 243, 244.

Swine, diseases of, I62-I66 ; — plague, 339; — plague bacillus, 25 .

Symbiosis, II5-II7.

Symptomatic anthrax, I8I, I82, $302,307,417$; bacillus of - , 57,66 .

Syphilis, 203, 204.

Tæniæ, $\mathbf{1 7 6 .}$

Tænia solium, 270 ; - mediocanellata, 270.

Temperature, behavior towards, $63-70,85,86$; rise of - , 382 .

Terminology, 235 .

Tetanus, 317, 318, 327, 329, 330, 337,358 ; - bacteria, 30 , 177: - toxin, I23, I79, $315,316,327,328,385$; serum, 35I.

Teukrin, 392.

Thiosinamin, 392 .

Thrush, 213.

Thymus, 390

Transmission of acquired characters, 246-248.

Tubercles of Leguminosæ, bacteria in, II 5 .

Tuberculin, 312-3I4, 344, 350, 380, 392.

Tuberculosis, I97, 243, 278, $313,392,402$; bacillus of $-, 34,35,42,43$, II 3, I 43 , 198, 263; miliary -, 207 ; peritoneal —, 392.

Typhoid fever, r9I, 380 ; bacteria, $25,34,328,344$; — serum, $356,380,38 \mathrm{I}$; 
toxin, 385 ; mouse typhoid, 196.

Jredineæ, 271.

Urschleim, 4 .

Ustilagineæ, 27 I.

Vaccination, 298, 299, 4I6, 4I7. Vacuoles, 4, 6.

Variability, 2I-23.

Vibrio, 23, 35, 36, 38 ;

choleræ asiaticæ, I9, 25, 36, rugula, $19,29,30$;

septicæmia, 307.

Virulence, diminution of, 30I, 427.

Water, bacteria in, 63,64 .

Water-supply, 4I9, 420, 423.

Yeasts, II6, II7, I27.

Yellow fever, 215, 243.

Zoöglœa, I4, 2O, 2I ; ramigera, I6. 



\section{Important Biological Publications}

THE PRIMARY. FACTORS OF ORGANIC EVOLUTION. By Prof. E. D. Cope. Cuts, I2r. Pp., xvi, 547. Cloth, $\$ 2.00$ (Ios.).

DARWIN AND AFTER DARWIN. An Exposition of the Darwinian Theory and a Discussion of Post-Darwinian Questions. By George John Romanes, LL. D., F. R. S., etc.

(For the American market only.)

I. The Darwinian Theory. With portrait of Darwin. Pp., 46o. I 25 cuts. Second edition. Cloth, $\$ 2.00$.

2. Post-Darwinian Questions. Heredity and Utility. With portrait of Romanes. Pp., 338. Cloth, \$I.50.

3. Post-Darwinian Questions. Isolation and Physiological Selection. With portrait of Mr. J. T. Gulick. Pp., I8r. 8vo. Cloth, \$I.oo.

(The three volumes supplied to one order for \$4.0o.)

AN EXAMINATION OF WEISMANNISM. By George John Romanes. Pp., ix, 22I, Cloth, \$I.oo. Paper, 35c.

THE PSYCHIC LIFE OF MICRO-ORGANISMS. By Dr. Alfred Binet. Authorised translation. Pp., xii, 12o. Cloth, 75c. (3s. 6d.); Paper, 25c. (Is. 6d.).

ON GERMINAL SELECTION. By August Weismann. Pp., xii, 6r. Paper, 25c. (Is. 6d.).

ON MEMORY, AND THE SPECIFIC ENERGIES OF THE NERVOUS SYSTEM. By Ewald Hering. 50 Pp. Paper, $15 \mathrm{c}$.

A MECHANICO-PHYSIOLOGICAL THEORY OF ORGANIC EVOLUTION. Summary. By Carl von Nägeli. Only original account of Nägeli's theories in English. Pp., 52. Paper, I5c.(9d.)

ON ORTHOGENESIS. By Th. Eimer. Pp., 56. Paper, $25 \mathrm{c}$. (rs. 6d.).

THE PRINCIPLES OF BACTERIOLOGY. By Dr. Ferdinand Huppe, Professor of Hygiene in the University of Prague. 28 Woodcuts. Pp., 465t. \$1.75 (7s. 6d.)

THE OPEN COURT PUBLISHING CO.

CHICAGO: 324 Dearborn Street.

LONDON: Kegan Paul, Trench, Trübner \& Co. 


\section{CATALOGUE OF PUBLICATIONS}

OF THE

\section{OPEN COURT PUBLISHING CO.}

COPE, E. D.

THE PRIMARY FACTORS OF ORGANIC EVOLUTION.

I2I cuts. Pp., xvi, 547. Cloth, \$2.00, net.

MÜLLER, F. MAX.

THREE INTRODUCTORY LECTURES ON THE SCIENCE OF THOUGHT.

128 pages. Cloth, 75 cents. Paper, 25 cents.

THREE LECTURES ON THE SCIENCE OF LANGUAGE.

112 pages. 2nd Edition. Cloth, 75 cents. Paper, 25c.

ROMANES, GEORGE JOHN.

DARWIN AND AFTER DARWIN.

An Exposition of the Darwinian Theory and a Discussion of PostDarwinian Questions. Three Vols., \$4.00. Singly, as follows:

I. The Darwinian Theory. 460 pages. 125 illustrations. Cloth, \$2.00.

2. Post-Darwinian Questions. Heredity and Utility. Pp. 338. \$1.50.

3. Post-Darwinian Questions. Isolation and Physiolngical Selection. Pp. 181. \$1.00.

AN EXAMINATION OF WEISMANNISM. 236 pages. Cloth, $\$ 1.00$. Paper, $35 \mathrm{C}$.

THOUGHTS ON RELIGION.

Edited by Charles Gore, M.A., Canon of Westminster. Third Edition, Pages, 184. Cloth, gilt top, \$1.25.

RIBOT, TH.

THE PSYCHOLOGY OF ATTENTION.

THE DISEASES OF PERSONALITY.

THE DISEASES OF THE WILL.

Authorised translations. Cloth, 75 cents each. Paper, 25 cents. Full set. clnth, \$1.75, net.

EVOLUTION OF GENERAL IDEAS.

(In preparation.)

MACH, ERNS'T.

THE SCIENCE OF MECHANICS.

A Critical and Historical Exposition of its Principles. Translated by T. J. McCormack. 250 cuts. 534 pages. $1 / 2 \mathrm{~m}$., gilt top. $\$ 2.50$.

POPULAR SCIENTIFIC LECTURES.

Third Edition. 415 pages. 59 cuts. Cloth, gilt top. Net, $\$ 1.50$.

THE ANALYSIS OF THE SENSATIONS.

Pp. 208. 37 cuts. Cloth, $\$ 1.25$, net.

LAGRANGE, J. L.

LECTURES ON ELEMENTARY MATHEMATICS.

With portrait of the author. Pp. 172. Price, $\$ 1.00$, net.

HUC AND GABET, MM.

TRAVELS IN TART 4 RY. THIBET AND CHINA.

(1844-1846.) Translated from the French by W. Hazlitt. Illustrated with 100 engravings on wood. 2 vols. Pp. $28+660$. Cl., $\$ 2.00$ (IOs.).

CORNILL, CARL HEINRICH.

THE PROPHETS OF ISRAEL.

Popular Sketches from Old Testament History. Pp., 200, Cloth, \$1.0n. HISTORY OF THE PEOPLE OF ISRAEL.

Pp. vi + 325. Cloth, \$1.50.

BINET, ALFRED.

THE PSYCHIC LIFE OF MICRO-ORGANISMS.

Authorised translation. I35 pages. Cloth, 75 cents; Paper, 25 cents.

ON DOUBLE CONSCIOUSNESS. See No. 8, Relig. of Sclence Library. 
WAGNER, RICHARD.

A PILGRIMAGE TO BEETHOVEN.

A Novelette. Frontispiece, portrait of Beethoven. Pp. 40. Boards, $50 c$

HUTCHINSON, WOODS.

THE GOSPEL ACCORDING TO DARWIN.

Pp., xii + 24I. Price, $\$ 1.50$.

FREYTAG, GUSTAV.

THE LOST MANUSCRIPT. A Novel.

2 vols. 953 pages. Extra cloth, $\$ 4.00$. One vol., cl., $\$ 1.00$; paper, $75 \mathrm{C}$

MARTIN LUTHER.

Illustrated. Pp. 130. Cloth, \$1.00. Paper, 25c.

TRUMBULL, M. M.

THE FREE TRADE STRUGGLE IN ENGLAND.

Second Edition. 296 pages. Cloth, 75 cents; paper, 25 cents.

WHEELBARROW: ARTICLES AND Discussions on the LABOR QUeStion With portrait of the author. 303 pages. Cloth, $\$ 1.00$; paper, 35 cents.

GOETHE AND SCHILLER'S XENIONS.

Selected and translated by Paul Carus. Album form. Pp., I62. Cl., \$1.00

OLDENBERG, $\mathrm{H}$.

ANCIENT INDIA: ITS LANGUAGE AND RELIGIONS.

Pp. 100. Cloth, 50c. Paper, 25c.

CARUS, PAUL.

THE ETHICAL PROBLEM. 90 pages. Cloth, 50 cents; Paper, 30 cents.

FUNDAMENTAL PROBLEMS.

Second edition, enlarged and revised. $372 \mathrm{pp}$. Cl., \$1.50. Paper, 50c.

HOMILIES OF SCIENCE.

317 pages. Cloth, Gilt Top, \$r.50.

THE IDEA OF, GOD.

Fourth edition. 32 pages. Paper, 15 cents.

THE SOUL OF MAN.

With 152 cuts and diagrams. 458 pages. Cloth, $\$ 3.00$.

TRUTH IN FICTION. Twelve Tales with a Moral.

Fine laid paper, white and gold binding, gilt edges. Pp. rIr. \$1.00.

THE RELIGION OF SCIENCE.

Second, extra edition. Price, 50 cents. R.S. L. edition 25c. Pp. 103.

PRIMER OF PHILOSOPHY.

240 pages. Second Edition. Cloth, \$1.00. Paper, 25c.

THE GOSPEL OF BUDDHA. According to Old Records. 4th Edition. Pp., 275. Cloth, \$1.00. Paper, 35 cents. In German, \$1.25.

BUDDHISM AND ITS CHRISTIAN CRITICS. Pages, 311. Cloth, \$1.25.

KARMA. A STORY OF EARLY BUDdHISM.

Illustrated by Japanese artists. 2nd Edition. Crêpe paper, 75 cents.

NIRVANA: A STORY OF BUDDHIST PSYCHOLOGY. Japanese edition, like Karma. \$1.00.

LAO-TZE'S TAO-TEH-KING.

Chinese-English. With introduction, transliteration, Notes, etc. Pp 36o. Cloth, $\$ 3.00$.

GARBE, RICHARD.

THE REDEMPTION OF THE BRAHMAN. A TALE OF HINDU LifE. Laid paper. Gilt top. 96 pages. Price, 75c. Paper, 25c.

THE PHILOSOPHY OF ANCIENT INDIA.

Pp. 89. Cloth, 5oc. Paper, 25 c.

HUEPPE, FERDINAND.

THE PRINCIPLES OF BACTERIOLOGY. 28 Woodcuts. Pp., $350+$. Price, $\$ 1.75$. (In preparation. 


\section{THE

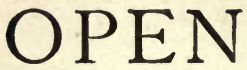 \\ COURT}

\section{A MONTHLY MAGAZINE}

\section{- Devoted to the Science of Religion, the Religion of Science, and the Extension of the Religious Parliament Idea.}

THE OPEN COURT does not understand by religion any creed or dogmatic belief, but man's world-conception in so far as it regulates his conduct.

The old dogmatic conception of Religion is based upon the science of past ages; to base religion upon the maturest and truest thought of the present time is the object of The Open Court. Thus, the religion of The Open Court is the Religion of Science, that is, the religion of verified and verifiable truth.

Although opposed to irrational orthodoxy and narrow bigotry, The Open Court does not attack the properly religious element of the various religions. It criticises their errors unflinchingly but without animosity, and endeavors to preserve of them all that is true and good.

The current numbers of The Open Court contain valuable original articles from the pens of distinguished thinkers. Accurate and authorized translations are made in Philosophy, Science, and Criticism from the literature of Continental Europe, and reviews of noteworthy recent investigations are presented. Portraits of eminent philosophers and scientists are published, and appropriate illustrations accompany some of the articles.

Terms: $\$ 1.00$ a year; $\$ 1.35$ to foreign countries in the Postal Union. Single Copies, ro cents.

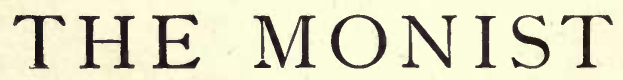

A QUARTERLY MAGAZINE OF .

\section{PHILOSOPHY AND SCIENCE.}

THE MONIST discusses the fundamental problems of Philosophy in their practical relations to the religious, ethical, and sociological questions of the day. The following have contributed to its columns:

Prof. Joseph le :onte, Prof. G. J. Romanes, Prof. C. Lombroso,

Dr. W. T. HARR:

M. D. Conway, James Sully,

Charles S. Peirce, B. Bosanduet,

Prof. F. MAX MŨLLER, DR. A. BINET,

Prof. E. D. Cope, PROF. ERNST MACH,

Carus Sterne, Rabi Emil Hirsch,

Mrs. C. LAdD Franklin, Lester F. Ward,

Prof. MAX VERWORN, PROF. H. SCHUBERT,

PROF. H. HÖFFDING,

DR. F. OSWALD,

Prof. J. Delbeut,

PROF. F. JODL,

Prof. H. M. Stanley,

Prop. Felix KleiN,

Dr. EDM. MONTGOMERY, Prof. H. von Holst,

Per copy, 5o cents; Yearly, \$2.00. In England and all countries in U.P.U. per copy, 2s 6d; Yearly, 9s 6d.

\section{CHICAGO :}

\section{THE OPEN COURT PUBLISHING CO., \\ Monon Building, 324 Dearborn St. \\ LONDON: Kegan Paul, Trench, Trübner \& Co.}




\section{The Religion of Science Library.}

A collection of bi-monthly publications, most of which are reprints of books published by The Open Court Publishing Company. Yearly, $\$ 1.50$ Separate copies according to prices quoted. The books are printed upon good paper, from large type.

The Religion of Science Library, by its extraordinarily reasonable price, will place a large number of valuable books within the reach of all readers

The following have already appeared in the series:

No. 1. The Religion of Science. By Paul Carus. 25c.

2. Three Introductory Lectures on the Science of Thought. By F. MAx Müller. 25c.

3. Three Lectures on the Science of Language. By F. MAx Moller. 25C.

4. The Diseases of Personality. Ву Тн. Rівот. $25 \mathrm{c}$.

5. The Psychology of Attention. By Tн. Riвот. $25 \mathrm{C}$.

6. The Psychic Life of Micro-Organisms. By Alfred Binet. $25 \mathrm{C}$.

7. The Nature of the State. By Paul Carus. I5c.

8. On Double Consciousness. By Alfred Binet. I5C.

9. Fundamental Problems. By Paul Carus. 5oc.

Io. 'The Diseases of the Will. By Tн. Riвот. $25 \mathrm{c}$.

II. The Origin of Language. By Ludwig NoIRE. ${ }^{5}$ c.

12. The Free Trade Struggle in England. By M. M. TRUMBULL. 25C.

13. Wheelbarrow on the Labor Question. By M. M. TRUMBULL. 35C.

14. The Gospel of Buddha. By PAUL CARUs. 35c.

15. The Primer of Philosophy. By Paul Carus. 25c.

16. On Memory, and The Specific Energies of the Nervous System. By Prof

Ewald Hering. 15c.

17. The Redemption of the Brahman. ATale of Hindu Life. By RICHARD

Garbe. 25c.

18. An Examination of Weismannism. By G. J. Romanes. $35 \mathrm{C}$.

19. On Germinal Selection. By August Weismann. 25c.

20. Lovers Three Thousand Years Ago. By T. A. Goor win. I5c.

2x. Popular Scientific Lectures. By ERNEst MACH. 5oc.

22. Ancient India: Its Language and Religions. By H. OldenBerg. 25c

23. The Prophets of Ancient Israel. By Prof. C. H. Cornill. 25 C.

24. Homilies of Science. By Paul Carus. $35 \mathrm{C}$.

25. Thoughts on Religion. By G. J. Romanes. 50 cents.

26. The Philosophy of Ancient India. By Prof. RIchard Garbe.

27. Martin Luther. By Gustav Freytag. 25c.

28. English Secularism. By George JaCob Holyoake. 25c.

29. On Orthogenesis. By TH. EIMER. $25 \mathrm{C}$.

30. Chinese Philosophy. By Paul Carus. 25c.

31. The Lost Manuscript. By Gustav Frieytag. $60 c$.

32. A Mechanico-Physiological Theory of Organic Evolution. By CARL von

NAEGELI. I5C.

\section{THE OPEN COURT PUBLISHING CO.}

\section{Dearborn Street, Chicago, Ill.}

LONDON: Kegan Paul, Trench, Trübner \& Co. 




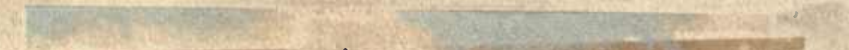

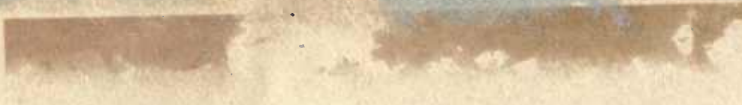

- 
80982

$$
\text { QR } 41
$$

W. UIOGY

LIBRARY

$$
\text { H } 85
$$

C

THE UNIVERSITY OF CALIFORNIA LIBRARY 
